\title{
IMPACT OF CLIMATE CHANGE-INDUCED DROUGHT ON TREE ROOT HYDRAULIC PROPERTIES AND COMPETITION BELOWGROUND
}

\author{
Dissertation \\ zur Erlangung des Doktorgrades \\ der Mathematisch-Naturwissenschaftlichen Fakultäten \\ der Georg-August-Universität zu Göttingen
}

vorgelegt von

Boris Rewald

aus Kassel

Göttingen, 18. März 2008 
D 7

Referent: Prof. Dr. Christoph Leuschner

Korreferent: PD Dr. Dirk Gansert

Tag der mündlichen Prüfung: 30.04.2008 


\section{Summary}

Drought has been projected to increase as global warming progresses, putting forest health in jeopardy. Water availability already is a major factor limiting plant growth, especially in forests and orchards on shallow, sandy soils or in regions with low precipitation. Furthermore, salinisation of agricultural soils is an increasing problem, often caused by the increased water demand for irrigation in drier climates.

Research on drought and salt resistance strategies of plants has classically focussed on the dynamics of stem and leaf water. However, it is in the soil where water uptake occurs and plants compete for water and nutrients. Although an increasing number of studies are addressing belowground traits, a better understanding of the adaptability of tree root systems to water limitation and belowground competition is needed to be able to predict the effects of climate change on mature forest stands and woody crops.

This study on five tree species in temperate mixed forests and Mediterranean fruit tree orchards aims at answering important questions on the influence of reduced soil moisture and competitive interactions on structure and function of tree root systems. In particular, the aims of this study were to test whether (i) root hydraulic conductivity decreases in response to water shortage as does shoot hydraulic conductivity, (ii) fine roots act as 'hydraulic fuses' of the soil-plant-atmosphere continuum, (iii) the belowground competitive ability is symmetric and directly linked to root system size, and (iv) belowground competitive ability differs between tree species and is not modified by resource availability.

This study showed that:

i) Quercus petraea (MATT.) LIEBL. generally responded to moderate or severe drought with an increase in root axial conductivity, while Fagus sylvatica L. mostly did not. The same pattern was found in salt-stressed Olea europaea L. roots, the conductivity of which increased in response to increasing salinity. Drought- and/or salt-adapted tree species such as Quercus petraea and Olea europea seem to be capable of partly compensating for water shortage-induced root biomass losses by increasing root axial conductivity, a mechanism rarely observed in aboveground organs.

ii) Fine roots can act as 'hydraulic fuses' in the soil-plant-atmosphere continuum. In addition to most previous studies, which suggest root shedding as the underlying 
mechanism, this study indicates cavitation to be another, potentially reversible, 'hydraulic fuse' mechanism. This conclusion is based on the very high vulnerability of small-diameter roots of both Quercus and Fagus to cavitation and the further increase of this vulnerability in drought-stressed Quercus roots.

iii) This study revealed two lines of evidence for the existence of asymmetry in belowground competition: fine root biomass of Quercus petraea was over-proportionally reduced in species-rich allospecific stand patches as compared to monospecific ones, and root growth rates and morphology depended on the competitor present but not on initial root system size differences.

iv) Tree species may be ranked according to their belowground competitive ability. According to data on root biomass and root growth in experimentally altered neighbourhoods, Fagus sylvatica seems to be a superior competitor belowground. However, a marked asymmetry in the outcome of root competition only developed when soil moisture in summer was sufficiently high. Resource limitation, i.e. drought, seems to affect the competitive ability of Fagus sylvatica and Quercus petraea roots in a similar manner with the consequence that species-specific differences in competitive ability are less conspicuous in more stressful environments. Therefore, the overall importance of direct biotic interactions belowground seems to be reduced by limited soil water availability. 


\section{Zusammenfassung}

Durch die mit dem Klimawandel einhergehende Temperaturerhöhung und den verringerten Niederschlag wird es in Zukunft häufiger zu Trockenperioden kommen. Wasser ist bereits heute ein das Pflanzenwachstum limitierender Faktor, insbesondere in Wäldern und Plantagen auf schwachgründigen, sandigen Böden sowie in Regionen mit geringem Niederschlag. Zudem fördert der erhöhte Bewässerungs-Bedarf unter trockeneren klimatischen Bedingungen die Versalzung von landwirtschaftlichen Böden.

Obwohl die Wasseraufnahme und Konkurrenzprozesse um Wasser und Nährstoffe im Boden stattfinden, lag der Schwerpunkt bei der Erforschung von pflanzlichen Anpassungsstrategien an Trockenheit und Salz-Stress in der Vergangenheit häufig auf den oberirdischen Pflanzenorganen. Um die Effekte des Klimawandels vorhersagen zu können, ist jedoch ein besseres Verständnis für die Anpassungsfähigkeit von Wurzelsystemen an Trockenheit und unterirdische Konkurrenzprozesse nötig.

Diese Studie über fünf Baumarten temperater Mischwälder und mediterraner Obstbaum-Plantagen untersucht den Einfluss reduzierter Bodenwasserverfügbarkeit und unterirdischer Konkurrenzprozesse auf die Struktur und Funktion von Wurzelsystemen.

Insbesondere soll in dieser Studie geklärt werden, ob (i) die axiale hydraulische Leitfähigkeit von Wurzeln, analog zur Anpassung oberirdischer Organe, mit zunehmender Trockenheit abnimmt, (ii) Feinwurzeln im Boden-Pflanze-Atmosphäre-Kontinuum als „hydraulische Sicherungen“ fungieren, und (iii) die unterirdische Konkurrenzkraft symmetrisch zur Größe des Wurzelsystems ist bzw. (iv) zwischen Baumarten und mit der Wasser- und Nährstoffversorgung variiert.

Durch diese Studie konnte nachgewiesen werden, dass

i) Die axiale hydraulische Leitfähigkeit der Fein- und Grobwurzeln von Quercus petraea (MATT.) LIEBL., im Gegensatz zu Wurzeln von Fagus sylvatica L., bei starker Bodentrockenheit zunimmt. An Wurzeln von Olea europaea L. konnte zudem eine Zunahme der hydraulischen Wurzel-Leitfähigkeiten mit zunehmendem Salzgehalt des Bodens beobachtet werden.

An Trockenheit und/oder Salz-Stress angepasste Baumarten wie Quercus petraea und Olea europea sind vermutlich in der Lage, den durch den Verlust an Wurzelbiomasse erhöhten hydraulischen Widerstand durch eine Verminderung der axialen Wurzel- 
Leitungswiderstände zu kompensieren. In Sprossen und Zweigen konnte ein ähnlicher Anpassungsmechanismus bislang nur vereinzelt nachgewiesen werden.

ii) Feinwurzeln als „hydraulische Sicherungen“ im Boden-Pflanze-AtmosphäreKontinuum wirken können. Das Xylem von Quercus petraea und Fagus sylvatica Feinwurzeln emboliert bereits bei geringfügig verminderten Wasserpotentialen. Darüber hinaus erhöht sich die Embolieanfälligkeit der Feinwurzeln von Quercus petraea nach Bodentrockenheit. Neben dem Absterben von lateralen Feinwurzeln scheinen Embolien als weiterer, eventuell reversibler, hydraulischer Sicherungsmechanismus zu wirken.

iii) Verschiedene Anzeichen auf die Asymmetrie der unterirdischen Konkurrenzprozesse hindeuten. Zum Einen ist die Feinwurzelbiomasse von Quercus petraea unter interspezifischen Konkurrenzbedingungen im Vergleich zu Reinbeständen überproportional reduziert, zum Anderen hängt die Wachstumsrate und Morphologie von Wurzeln von der Anwesenheit eines Konkurrenten und nicht von der Anfangsbiomasse ab.

iv) Baumarten anhand ihrer unterirdischen Konkurrenzkraft gegliedert werden können. Den Ergebnissen über Wurzelbiomasse und -wachstum unter unterschiedlichen Konkurrenzbedingungen zur Folge, ist Fagus sylvatica nicht nur ober-, sondern auch unterirdisch eine der konkurrenzstärksten Baumarten Mitteleuropas. Unter zunehmendem abiotischem Stress verlieren artspezifische Unterschiede in der Konkurrenzkraft jedoch an Bedeutung und die Wichtigkeit biotischer Interaktionen ist vermindert. Eine Einschränkung der Ressourceverfügbarkeit, z.B. durch Trockenheit, scheint die Konkurrenzkraft von Fagus sylvatica und Quercus petraea in gleicher Weise zu beeinflussen. 


\section{Table of contents}

1 Introduction

1.1 Impact of climate change on Central European and Mediterranean forests... 12

1.2 Influence of water shortage on the hydraulic system of trees ...................... 14

1.3 Belowground competition in mixed forest stands - reciprocity with resource availability 15

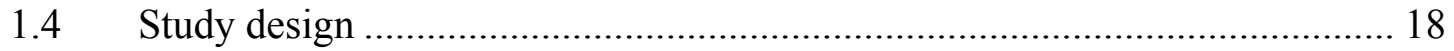

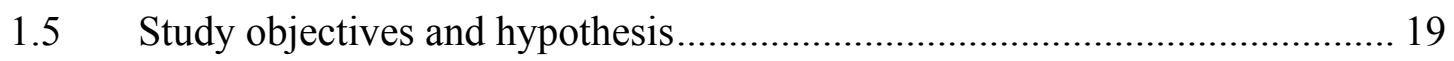

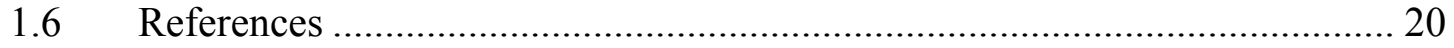

2 Drought-induced changes in axial conductivity and vulnerability to embolism in roots of two broad-leaved tree species with contrasting drought-tolerance ........................ 26

3 Does root xylem plasticity affect salt tolerance? .................................................. 51

4 Belowground competition in a broad-leaved temperate mixed forest - pattern analysis

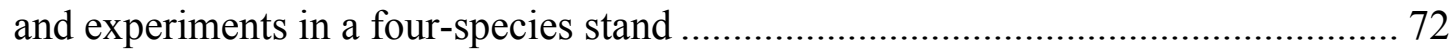

5 Does root competition asymmetry increase with water availability? ..................... 101

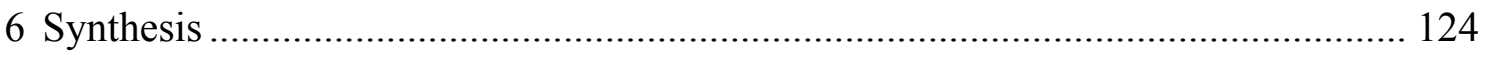

6.1 Belowground adaptations of trees to water shortage and the role of

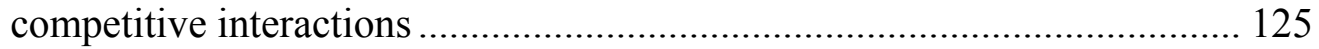

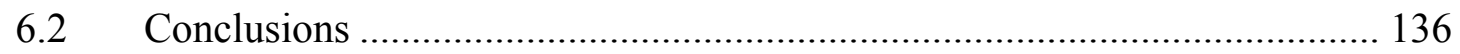

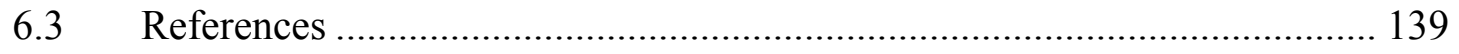

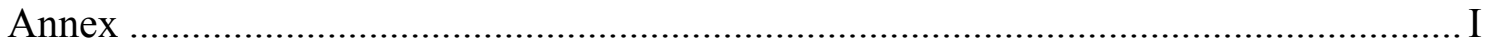

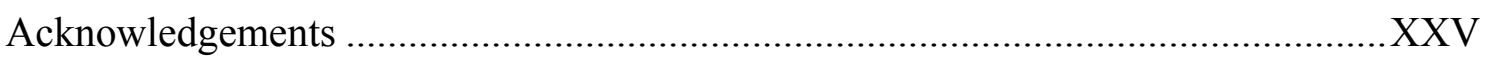

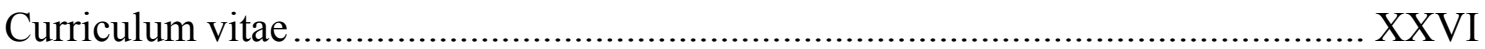




\section{Index of Figures}

Fig. 1.1 Projected temperature and precipitation changes in Europe...................13

Fig. 1.2 Morphological characteristics of beech and oak fine roots...................16

Fig. 2.1 Specific conductivity of fine and coarse roots of beech and oak trees..........36

Fig. 2.2 Specific conductivity and degree of embolism of beech and oak shoots.........38

Fig. 2.3 Vulnerability curves of small-diameter roots of beech and oak............. 40

Fig. 2.4 $\Psi_{\mathrm{PLC} 50} v s$. root cross-sectional area of roots of beech and oak saplings........ 41

Fig. 3.1 LM-micrographs of a normal and a high-conductivity Barnea root.............59

Fig. 3.2 HWCD and MAXCD of fine and coarse roots of olive trees.................60

Fig. 4.1 BAI of mature hornbeam, beech, oak, and linden trees.....................83

Fig. 4.2 Fine root biomass of hornbeam, beech, oak, and linden trees................83

Fig. 4.3 Relation between root biomass and distance to the nearest conspecific stem... 85

Fig. 4.4 Fine root biomass as dependent on the number of tree species present..........86

Fig. 4.5 Competitive ability belowground in a mixed stand ....................... 89

Fig. 5.1 RGR of beech and oak fine roots upon competition and drought stress.......110

Fig. 5.2 $\Delta \mathrm{CA}$ of beech and oak fine roots along a moisture gradient................ 111

Fig. 6.1 Fine root biomass of beech and oak sapling upon drought...................126

Fig. 6.2 Fine root densities of mature beech and oak trees upon drought.............128

Fig. 6.3 Proline concentration in roots of drought-stressed beech and oak trees.......131

Fig. A 1 Apparatus for measurement of axial hydraulic conductivity...................

Fig. A 2 Apparatus to determine the vulnerability to embolism......................

Fig. A 3 The in situ-root growth chamber....................................

Fig. A 4 Sub-canopy roof in the Unterlüß forest and the saplings experiment.............II

Fig. A 5 Olive orchard at the Ramat Negev Experimental Station....................III

Fig. A 6 Mixed stand in the Ziegelrodaer forest..................................II 


\section{Index of Tables}

Table 1.1 Possible changes in the hydraulic system due to water shortage..............14

Table 2.1 Structural characteristics of the mixed oak-beech forest at Unterlüß.........30

Table 2.2 Soil moisture content during the summer months in the Unterlüß forest......31

Table 2.3 Specific conductivity and cavitation in beech and oak roots.................37

Table 2.4 $\Psi_{\text {PLC50 }}$ in small-diameter roots of beech and oak saplings..................39

Table 3.1 Anatomical properties of olive roots.................................. 58

Table 3.2 Conduit diameter distribution in fine and coarse roots of olive.............61

Table 3.3 Proportion of conduit diameter classes on theoretical conductivity...........62

Table 3.4 Mean specific conductivity and degree of embolism in olive roots..........64

Table 4.1 Stand structural characteristics of the Ziegelrodaer forest................. 76

Table 4.2 Root necromass and root area index in the Ziegelrodaer forest..............84

Table 4.3 Morphological parameters of hornbeam, beech, oak and linden roots........84

Table 4.4 Frequency of soil samples containing fine roots of 1 to 4 tree species....... 86

Table 4.5 Fine root biomass in conspecific and allospecific stand patches............87

Table 4.6 Root RGR as dependent on the presence of competitors..................88

Table 5.1 Structural characteristics of the stands in Unterlüß and Ziegelroda.........105

Table 5.2 Volumetric soil moisture of the Unterlüß forest..........................106

Table 5.3 SRA, RSAI, and CA under different soil moisture treatments.............112

Table A 1 Effect of drought or salinity on the root biomass of conifers................IV

Table A 2 Effect of drought or salinity on the root biomass of woody angiosperms.....V

Table A 3 Studies on herbs and grasses suggesting a competitive mode belowground.VI

Table A 4 Studies on woody plants suggesting a competitive mode belowground....VIII

Table A 5 Reviews and models discussing the competitive mode belowground...........IX

Table A 6 Influence of drought or salinity on the axial conductivity $(\mathrm{k})$ of conifers......X

Table A 7 Influence of drought or salinity on $\mathrm{k}$ of woody angiosperms................XII 
'Now would I give a thousand furlongs of sea for an acre of barren ground - long heath, brown furze, any thing. The wills above be done, but I would fain die a dry death.'

William Shakespeare, The Tempest 
Chapter 1

INTRODUCTION 


\subsection{IMPACT OF Climate CHANGE ON CENTRAL EUROPEAN AND MEDITERRA- NEAN FORESTS}

Forests cover more than $4.1 \times 10^{7} \mathrm{~km}^{2}$ of the Earth's land area, contain $80 \%$ of the world's aboveground and $40 \%$ of belowground terrestrial carbon, and host much of the world's biodiversity (e.g. Dixon et al. 1994, Lindenmayer and Franklin 2002). They provide wood and crops as well as important 'services' such as facilitating ground water recharge, stabilizing slopes, providing space for recreation, and acting as carbon sinks (Ziemer 1978, Riestenberg and Sovonickdunford 1993, Goodale et al. 2002, Zandersen et al. 2007).

There is now convincing evidence that the global climate is changing at an unprecedented rate, putting forest health in jeopardy (IPCC 2007). A large proportion of the observed rise in global temperatures has been attributed to human activities: changes in the albedo of the earth's surface due to land-use changes and the increasing greenhouse gas emissions from intensive agriculture and fossil fuel burning have been identified as the main causes for global climate warming (Houghton 1994, Crowley 2000, IPCC 2007).

The general effects of increasing $\mathrm{CO}_{2}$ and the associated changes in temperature on aboveground tree function and growth have been reviewed elsewhere (Eamus and Jarvis 1989, Norby et al. 1999, Broadmeadow et al. 2005), whereas information about belowground responses is still scarce (Brunner and Godbold 2007). In brief, rising concentrations of $\mathrm{CO}_{2}$ are known to enhance photosynthesis and above- and belowground growth of tree seedlings as long as water and nutrient supply are sufficient (Broadmeadow and Randle 2002). This holds also true for some mature forest stands (Spiecker 1999, Lukac et al. 2003, Norby et al. 2005). Nevertheless, no enhancement of productivity could be observed in forests subjected to free-air $\mathrm{CO}_{2}$ enrichment that were possibly limited by water and nutrient supply (Oren et al. 2001, Karnosky 2003, Luo et al. 2004).

Water availability is a major factor limiting forest growth (Pigott and Pigott 1993, Stephenson 1990, Olson et al. 2001). In most parts of Central Europe, moderate drought stress is typically to be expected during short rainless periods that occur at irregular intervals in most summers (Backes and Leuschner 2000, Czajkowski et al. 2005) while severe droughts are episodic events (Lloyd-Huges and Saunders 2002). In the Mediter- 
ranean Basin water is strongly limiting plant growth and survival (Roy et al. 1987, Lloret et al. 2004), which is especially true for most Mediterranean tree genera, since they are thought to have evolved before the onset of the present summer-dry climate (Petit et al. 2005).

Model calculations of the future climate predict an increasing frequency and severity of exceptional summer droughts and heatwaves in various parts of Central Europe (Kunstmann et al. 2004, Rowell 2005, Forkel and Knoche 2006, Frei et al. 2006), and a disproportionately strong increase of summer temperature and aridity in the Mediterranean Basin (Fig. 1.1; Iglesias et al. 2000, IPCC 2007).
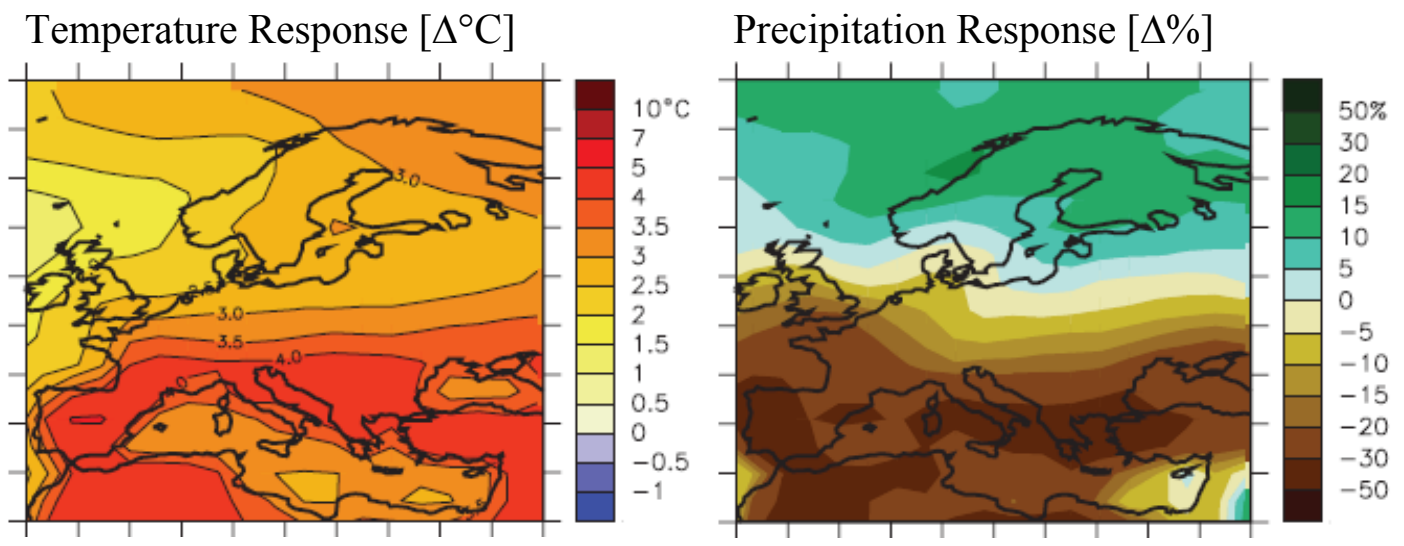

Fig. 1.1 Projected temperature (left) and precipitation (right) changes in Europe and the Mediterranean Basin between 1980-1999 and 2080-2099. Means of summer months (June - August) are given (IPCC 2007, modified).

The most vulnerable regions to climate change in Central Europe and the Mediterranean Basin are those, where soil moisture is already limited by geographical (e.g. warm and dry areas in Eastern Germany and Southern Europe) or pedological aspects (e.g. shallow or sandy soils resulting in low water storage capacity) under present site conditions (Kellomäki et al. 2000). The Mediterranean is particularly prone to climate change due to the high natural climate variability (Lionnello et al. 2006), the already most severe and precarious water scarcity (ESCWA 2007, Iglesias et al. 2007), and the susceptibility to secondary soil salinization by the increased demand for irrigation in drier climates (Centritto 2002).

Consequently, predictions of the effects of climate change on tree species and forests cannot be based on $\mathrm{CO}_{2}$ concentration only: water availability and temperature will play central roles in determining the future structure and function of forest ecosystems (Kellomäki et al. 2000, Pan et al. 2001, Christensen et al. 2007). 


\section{INFLUENCE OF WATER SHORTAGE ON THE HYDRAULIC SYSTEM OF TREES}

The soil-plant-atmosphere continuum refers to the coherence of water columns from the soil into plant roots, through stems and twigs into the leaves and, via transpiration, to the atmosphere (van den Honert 1948). Increasing evaporative demands and drier soils as predicted for the future will subject this 'hydraulic rope' to aggregated stress, thus endangering the continuous water supply to the leaves (Tyree and Zimmermann 2003, Santiago et al. 2004).

The whole-plant acclimation to water deficits has been reviewed by Bartels and Sunkar (2005), and Maseda and Fernández (2006). In summary, maximizing gas exchange while avoiding hydraulic failure requires the harmonization of at least three parameters: stomatal sensitivity, xylem vulnerability to embolism, and leaf-specific hydraulic conductivity. Studies investigating plant responses to water shortage, induced either by drought or salinity, have highlighted the importance of adjustments in the hydraulic system (Tables 1.1, A 6, A 7; Sperry et al. 1998, Holbrook and Zwieniecki 2005), as part of an whole-plant adaptation to drought stress (Shumway et al. 1991, Bond and Kavanagh 1999, Meinzer 2002). In the hydraulic system, axial hydraulic conductivity $\left(\mathrm{k}_{\mathrm{h}}\right)$, which gives the mass flow rate $\left(\mathrm{kg} \mathrm{s}^{-1}\right)$ of water through a shoot or root segment relative to the pressure gradient $\left(\mathrm{MPa} \mathrm{m}^{-1}\right)$, is of particular importance.

Table 1.1 Changes in the hydraulic system due to water shortage that influences axial hydraulic conductivity ( $\mathrm{k}_{\mathrm{h}}$; Maseda and Fernández 2006, modified).

\begin{tabular}{lllll}
\hline $\begin{array}{l}\text { Structure or } \\
\text { process }\end{array}$ & $\begin{array}{l}\text { Level of } \\
\text { Organisation }\end{array}$ & Time scale & $\begin{array}{c}\text { Effect } \\
\text { on } \mathbf{k}_{\mathbf{h}}\end{array}$ & References (examples) \\
\hline $\begin{array}{c}\text { Decreased aquaporin } \\
\text { activity }\end{array}$ & $\begin{array}{l}\text { Subcellular, } \\
\text { cell }\end{array}$ & Minutes, hours & $\downarrow$ & $\begin{array}{l}\text { Lovisolo } \text { et al. 2007 } \\
\text { Secchi } \text { et al. 2007 }\end{array}$ \\
$\begin{array}{c}\text { Decreased vessel } \\
\text { diameter, density }\end{array}$ & Tissue & Ontogeny & $\downarrow$ & $\begin{array}{l}\text { Arnold and Mauseth 1999 } \\
\text { Corcuera } \text { et al. 2004 }\end{array}$ \\
$\begin{array}{c}\text { Increased vessel } \\
\text { diameter, density }\end{array}$ & Tissue & Ontogeny & $\uparrow$ & $\begin{array}{l}\text { Junghans } \text { et al. 2006 } \\
\text { Maherali and DeLucia 2000 }\end{array}$ \\
$\begin{array}{c}\text { Decreased vulnerabil- } \\
\text { ity to xylem cavita- } \\
\text { tion }\end{array}$ & Tissue, organ & Ontogeny & $\downarrow$ & $\begin{array}{l}\text { Hacke } \text { et al. 2000 } 2002 \\
\text { Willson and Jackson 2006 }\end{array}$ \\
$\begin{array}{c}\text { Increased root:leaf } \\
\text { ratio (decreased wa- } \\
\begin{array}{c}\text { ter potential gradi- } \\
\text { ent) }\end{array}\end{array}$ & Whole plant & Ontogeny & $\uparrow$ & $\begin{array}{l}\text { Brodribb and Hill 2000 } \\
\text { Gieger and Thomas 2002 }\end{array}$ \\
\hline
\end{tabular}


In theory, increased hydraulic conductivities in response to drought stress could be as beneficial as decreased conductivities. Whereas an increase of $\mathrm{k}_{\mathrm{h}}$ could facilitate water uptake (Nardini and Pitt 1999, Mencuccini 2003, Maseda and Fernández 2006), a decrease is thought to help avoid cavitation (Hacke et al. 2001, Maherali et al. 2004) and reduce water loss to the atmosphere (Richards and Passioura 1989, Caldwell et al. 1998). Although it is known that vulnerability to drought-induced cavitation is not directly linked to xylem vessel diameters, it is associated with thicker cell walls in relation to lumen area (Hacke et al. 2001), resulting in reduced conductive areas. However, empirical studies have nearly always found the second response, i.e. a decrease in conductivity as a consequence of drought stress (see Tables A 6, A 7).

Previous work has shown that xylem properties can differ widely between plant organs in their adaptability to environmental stresses and their vulnerability to cavitation (Mills 1989, Martínez-Vilalta et al. 2002, Maherali et al. 2006). About half of total plant hydraulic resistance is located in the roots (Passioura 1988, Meinzer 2002). Furthermore, there is evidence that (i) ontogeny can modify the effects of water deficits and the sensitivity to drought (Cavender-Bares and Bazzaz 2000, Winkel et al. 2001), and (ii) drought-induced changes can hardly be analysed separately from allometric changes during ontogeny (Maseda and Fernández 2006).

Further research in this area is urgently needed to allow for predictions of responses of both mature forests and juvenile trees to future climate changes.

\subsection{BELOWGROUND COMPETITION IN MIXED FOREST STANDS - RECIPROCITY WITH RESOURCE AVAILABILITY}

Forests are not expected to respond to climate change as intact units, because of speciesspecific responses and interactions among species (Hanson et al. 2001). Influences of $\mathrm{CO}_{2}$ and ozone concentrations on trees are known to be modified by competitive interactions (Ceulemans et al. 1999, Liu et al. 2004), but predictions on the future composition of forests are still largely hampered by our limited understanding of the reciprocal effects of climate change and competitive interactions.

This is particularly true for belowground competition in mature forest stands. Several studies have provided convincing evidence that root competition is an important structuring force in many, if not most, terrestrial plant communities (Wilson 1988, Kajimoto 
et al. 2007). However, due to methodological reasons, belowground interactions between woody plants have mostly been studied in agroforestry systems (Nambiar and Sands 1993) or between adult and juvenile trees (Coomes and Grubb 2000, Barberis and Tanner 2005). Thus, the influence of root competition on tree growth, vitality and species coexistence in mixed forests is poorly understood, which makes it even more problematic to predict tree responses to a changing climate.

The mechanisms of belowground competition are assigned to two categories: exploitation (or resource-mediated) competition, and interference competition (e.g. Grace and Tilman 2003). Exploitation competition is based on the reduction of water and nutrient uptake by neighbouring roots. Traits that may influence this type of belowground competition are (i) root morphology and resource uptake rate (Fig. 1.2; Bauhus and Messier 1999, Leuschner et al. 2004, Bolte and Villanueva 2006), (ii) spatial and temporal soil occupation and root proliferation (Parrish and Bazzaz 1976, Robinson et al. 1999, Schenk 2006), and (iii) mycorrhization (Bolan 1991).
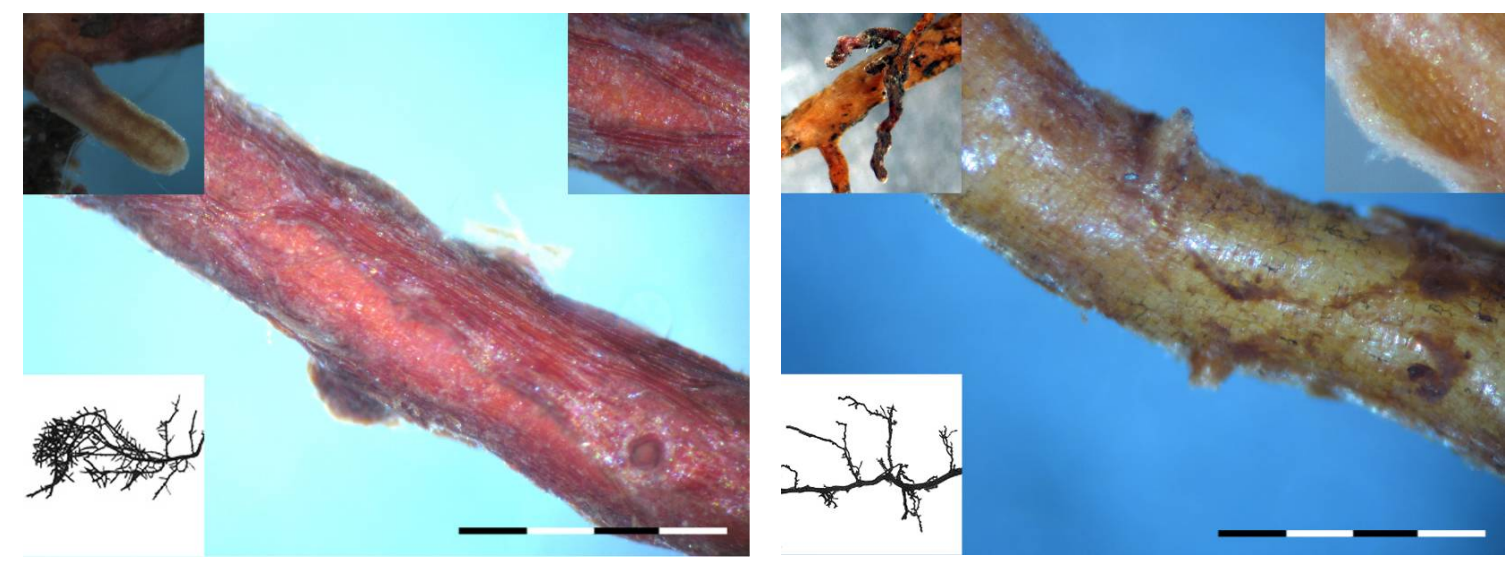

Fig. 1.2 Different morphological characteristics of Fagus sylvatica (left) and Quercus petraea (right) fine roots from the Unterlüß forest, NW Germany. Scale bars represent $1 \mathrm{~mm}$.

Interference competition includes allelopathy (Mahall and Callaway 1991, Jose et al. 2006), yet unknown root-root recognition systems (Callaway 2002, Falik et al. 2005), or root interactions with soil fauna or microorganisms (Schenk 2006).

Belowground competition would ideally be measured by quantifying the influence of belowground neighbourhoods on resource uptake, biomass, growth, or fecundity (Goldberg 1990, Schenk 2006) of individuals. However, whole-plant reductions in growth and vitality are difficult to detect in long-lived organisms such as mature trees, and short-term or single-resource-based physiological approaches may be misleading with 
regard to their ecological significance (Casper et al. 2000). Thus, criteria such as relative root growth rate (Grace 1995), root morphology (Bolte and Villanueva 2006), and the degree of root system overlap are more suitable to investigate belowground competition in mature forest stands, integrating the results of both exploitation and interference competition.

In contrast to aboveground competition, where larger individuals can obviously preempt light, belowground competition has been found to be either symmetric to root system size (Weiner et al. 1997, Cahill and Casper 2000) or asymmetric (Fransen et al. 2001, Rajaniemi 2003). Whereas the bulk of experimental evidence, mostly obtained in artificial 'communities', suggests that soil resource acquisition is size-symmetric, this may not be valid in natural environments with a considerable heterogeneity (Tables A 3-A 5; Jackson and Caldwell 1993, Schwinning and Weiner 1998). Larger and faster growing root systems may be able to exploit resources more completely (Thomas and Weiner 1989, Campbell et al. 1991, Van Lear and Kapeluck 1995), and uptake kinetics may differ between competing plant species (Aerts and Chapin 2000).

It is yet unclear whether belowground competition is symmetric or asymmetric, a property which may substantially influence population and community dynamics (Łomnicki 1980, Aikio and Pakkasmaa 2003). Moreover, there is a vital debate on the influence of resource availability on root competition. Two contrasting hypotheses have been formulated with regard to the intensity of belowground competition depending on nutrient and water availabilities: belowground competitive intensity can be either dependent (Grime 1979, Keddy 1989, Wilson and Tilman 1993), or independent (Newman 1973, Welden et al. 1988, Peltzer et al. 1998) of resource availability.

Modelling approaches predict strong responses of forest species composition to dryer climates (Kräuchi and Kienast 1993, Shao et al. 2003). However, these models are known to be largely hampered by the poor integration of biological processes, such as competition (Hallgren and Pitman 2000). A better understanding of competition in forests is therefore imperative. 


\section{$1.4 \quad$ STUDY DESIGN}

This study, including five tree species from Central Europe and the Mediterranean Basin, uses both descriptive and experimental approaches to assess the impact of water shortage on the morphology, structure and functionality of tree root systems.

The research was conducted at four locations in Central Germany and Southern Israel:

1. Unterlüß forest: Studies on the influence of drought stress on root hydraulic properties and belowground competition were carried out in an unmanaged old-growth mixed forest consisting of 120-year-old Fagus sylvatica L. (European beech) and 200-year-old Quercus petraea (MATT.) LIEBL. (Sessile oak) trees close to the village of Unterlüß (Lower Saxony, NW Germany; 52॰14’50 N, 10॰13’00 E; Fig. A 4).

2. Experimental Botanical Garden Göttingen: A study on the influence of drought stress on the root hydraulic properties of 4 to 6-year-old Fagus sylvatica and 5 to 7-year-old Quercus petraea saplings took place at the Experimental Botanical Garden of the University of Göttingen, Central Germany (51 $56^{\prime} \mathrm{N}, 09^{\circ} 96^{\prime} \mathrm{E}$; Fig. A 4).

3. Ramat Negev Experimental Station: A study on the influence of root hydraulic properties on the salt resistance of three 9-year-old Olea europea L. (olive) varieties was conducted in the orchards of the Ramat Negev Experimental Station, located in the central Israeli Negev Desert $\left(31^{\circ} 05^{\prime} 00 \mathrm{~N}\right.$, 34²1'03 E; Fig. A 5).

4. Ziegelrodaer forest: A study on belowground competition was carried out in a four-species mixed forest consisting of 120 to 130-year-old Fagus sylvatica and Quercus petraea trees, and of 70 to 90-year-old Tilia cordata MiLl. (linden) and Carpinus betulus L. (hornbeam) trees in the Ziegelrodaer forest in Saxony-Anhalt, Central Germany $\left(51^{\circ} 25^{\prime} \mathrm{N}, 11^{\circ} 31^{\prime} \mathrm{E}\right.$; Fig. A 6).

The following parameters were measured to assess the hydraulic properties and the competitive interactions of root systems of saplings and mature trees under different soil moisture availabilities:

1. root area index, specific root area, root bio- and necromass,

2. vertical and horizontal root distribution,

3. relative root growth rates,

4. root- and shoot-specific conductivity,

5. degree of embolism in roots and shoots,

6. root vulnerability to cavitation,

7. root xylem anatomy,

8. leaf area index, leaf biomass, and

9. basal area increment. 


\subsection{STUDY OBJECTIVES AND HYPOTHESIS}

This study focussed on five tree species from temperate mixed forests and Mediterranean fruit tree orchards and aimed at answering important questions on the influence of reduced soil moisture on structure and function of tree root systems. Our knowledge is particularly limited with respect to competitive interactions belowground and hydraulic adaptations of root systems.

Thus, the study placed particular emphasis on (i) the adaptability of the root hydraulic system to drought and salt stress, and (ii) the intensity and direction of belowground competition under conditions of limited water availability.

In particular, the aims of this study were:

1. to compare the root- and shoot-specific conductivities of contrasting tree species, varieties and ontogenetic stages under drought and salt stress,

2. to quantify the degree of root embolism and root vulnerability to cavitation,

3. to assess the contribution of root hydraulic properties to drought- and saltresistance,

4. to quantify the extent of root system overlap,

5. to compare the influence of reduced soil moisture and/or interspecific competition on root morphology,

6. to attempt a ranking of the tree species with respect to belowground competitive ability,

7. to determine whether belowground competition in mature forests is symmetric or asymmetric, and

8. to analyse whether root competition asymmetry changes with soil moisture availability or not.

I tested the hypotheses that (i) root hydraulic conductivity decreases in response to drought as well as shoot hydraulic conductivity, (ii) fine roots act as 'hydraulic fuses' of the soil-plant-atmosphere continuum to prevent runaway cavitation in the whole plant, (iii) the belowground competitive ability is symmetric to root system size, and (iv) belowground competitive ability differs between tree species and is not modified by resource availability. 


\subsection{REFERENCES}

Aerts R, Chapin III FS. 2000. The mineral nutrition of wild plants revisited: A re-evaluation of processes and patterns. Advances in Ecological Research 30: 1-67.

Aikio S, Pakkasmaa S. 2003. Relatedness and competitive asymmetry - implications for growth and population dynamics. Oikos 100: 283-290.

Arnold DH, Mauseth JD. 1999. Effects of environmental factors on development of wood. American Journal of Botany 86: 367-371.

Backes K, Leuschner C. 2000. Leaf water relations of competitive Fagus sylvatica and Quercus petraea trees during four years differing in soil drought. Canadian Journal of Forest Research 30: 335-346.

Barberis IM, Tanner EVJ. 2005. Gaps and root trenching increase tree seedling growth in Panamanian semi-evergreen forest. Ecology 86: 667-674.

Bartels D, Sunkar R. 2005. Drought and salt tolerance in plants. Critical Reviews in Plant Sciences 24: $23-58$

Bauhus J, Messier C. 1999. Soil exploitation strategies of fine roots in different tree species of the southern boreal forest of eastern Canada. Canadian Journal of Forest Research 29: 260-273.

Bolan NS. 1991. A critical review on the role of mycorrhizal fungi in the uptake of phosphorus by plants. Plant and Soil 134: 189-207.

Bolte A, Villanueva I. 2006. Interspecific competition impacts on the morphology and distribution of fine roots in European beech (Fagus sylvatica L.) and Norway spruce (Picea abies (L.) KARST.). European Journal of Forest Research 125: 15-26.

Bond BJ, Kavanagh KL. 1999. Stomatal behavior of four woody species in relation to leaf-specific hydraulic conductance and threshold water potential. Tree Physiology 19: 503-510.

Broadmeadow M, Randle T. 2002. The impacts of increased $\mathrm{CO}_{2}$ concentrations on tree growth and function. In: Broadmeadow MSJ, ed. Climate change and UK forests. Edinburgh, UK: Forestry Commission, 119-140.

Broadmeadow MSJ, Ray D, Samuel CJA. 2005. Climate change and the future for broadleaved tree species in Britain. Forestry 78: 145-161.

Brodribb TJ, Hill RS. 2000. Increases in water potential gradient reduce xylem conductivity in whole plants. Evidence from a low-pressure conductivity method. Plant Physiology 123: 1021-1027.

Brunner I, Godbold DL. 2007. Tree roots in a changing world. Journal of Forest Research 12: 78-82.

Cahill JF, Casper BB. 2000. Investigating the relationship between neighbor root biomass and belowground competition: field evidence for symmetric competition belowground. Oikos 90: 311-320.

Caldwell MM, Dawson TE, Richards JH. 1998. Hydraulic lift: Consequences of water efflux from the roots of plants. Oecologia 113: 151-161.

Callaway RM. 2002. The detection of neighbors by plants. Trends in Ecology and Evolution 17: 104-105.

Campbell BD, Grime JP, Mackey JML. 1991. A trade-off between scale and precision in resource foraging. Oecologia 87: 532-538.

Casper BB, Cahill JF, Jackson RB. 2000. Plant competition in spatial heterogeneous environments. In: Hutchings MJ, John EA, Stewart AJA, eds. Ecological consequences of habitat heterogeneity. Oxford, UK: Blackwell, 111-130.

Cavender-Bares JM, Bazzaz FA. 2000. Changes in drought response strategies with ontogeny in Quercus rubra: implications for scaling from seedlings to mature trees. Oecologia 124: 8-18.

Centritto M. 2002. Interactive effects of climate change and water stress: implications for water-limited environments. First FAO-UCEA technical workshop of the "Mediterranean" component of the ClimAgri project on climate change and agriculture. Rome, Italy: FAO. 
Ceulemans R, Janssens IA, Jach ME. 1999. Effects of $\mathrm{CO}_{2}$ enrichment on trees and forests: Lessons to be learned in view of future ecosystem studies. Annals of Botany 84: 577-590.

Christensen JH, Carter TR, Rummukainen M, Amanatidis G. 2007. Evaluating the performance and utility of regional climate models: the PRUDENCE project. Climatic Change 81: 1-6.

Cinnirella S, Magnani F, Saracino A, Borghetti M. 2002. Response of a mature Pinus laricio plantation to a three-year restriction of water supply: structural and functional acclimation to drought. Tree Physiology $22: 21-30$.

Coomes DA, Grubb PJ. 2000. Impacts of root competition in forests and woodlands: A theoretical framework and review of experiments. Ecological Monographs 70: 171-207.

Corcuera L, Camarero JJ, Gil-Pelegrín E. 2004. Effects of a severe drought on Quercus ilex radial growth and xylem anatomy. Trees - Structure and Function 18: 83-92.

Crowley TJ. 2000. Causes of climate change over the past 1000 years. Science 289: 270-277.

Czajkowski T, Kuhling M, Bolte A. 2005. Impact of the 2003 summer drought on growth of beech sapling natural regeneration (Fagus sylvatica L.) in north-eastern Central Europe. Allgemeine Forst- und Jagdzeitung 176: 133-143.

Dixon RK, Brown S, Houghton RA, Solomon AM, Trexler MC, Wisniewski J. 1994. Carbon pools and flux of global forest ecosystems. Science 263: 185-190.

Eamus D, Jarvis PG. 1989. The direct effects of increase in the global atmospheric $\mathrm{CO}_{2}$ concentration on natural and commercial temperate trees and forests. San Diego, USA: Academic Press.

ESCWA 2007. ESCWA water development report 2 - State of water resources in the ESCWA region. New York, USA: United Nations.

Falik O, Reides P, Gersani M, Novoplansky A. 2005. Root navigation by self inhibition. Plant, Cell and Environment 28: 562-569.

Forkel R, Knoche R. 2006. Regional climate change and its impact on photooxidant concentrations in southern Germany: Simulations with a coupled regional climate-chemistry model. Journal of Geophysical Research - Atmospheres 111 D12.

Fransen B, de Kroon H, Berendse F. 2001. Soil nutrient heterogeneity alters competition between two perennial grass species. Ecology 82: 2534-2546.

Frei C, Scholl R, Fukutome S, Schmidli R, Vidale PL. 2006. Future change of precipitation extremes in Europe: Intercomparison of scenarios from regional climate models. Journal of Geophysical Research Atmospheres 111 D6: 1-22.

Gieger T, Thomas FM. 2002. Effects of defoliation and drought stress on biomass partitioning and water relations of Quercus robur and Quercus petraea. Basic and Applied Ecology 3: 171-181.

Goldberg DE. 1990. Components of resource competition in plant communities. In: Grace JB, Tilman D, eds. Perspectives on plant competition. San Diego, USA: Academic Press, 27-49.

Goodale CL, Apps MJ, Birdsey RA, Field CB, Heath LS, Houghton RA, Jenkins JC, Kohlmaier GH, Kurz W, Liu SR, Nabuurs GJ, Nilsson S, Shvidenko AZ. 2002. Forest carbon sinks in the Northern Hemisphere. Ecological Applications 12: 891-899.

Grace JB. 1995. On the measurement of plant competition intensity. Ecology 76: 305-308.

Grace JB, Tilman D. 2003. Perspectives on plant competition. Caldwell, USA: Blackburn.

Grime JP. 1979. Plant strategies and vegetation processes. Chichester, UK: Wiley.

Hacke UG, Sperry J, Pittermann J. 2000. Drought experience and cavitation resistance in six shrubs from the Great Basin, Utah. Basic and Applied Ecology 1: 31-41.

Hacke UG, Sperry JS, Pockman WT, Davis SD, McCulloch KA. 2001. Trends in wood density and structure are linked to prevention of xylem implosion by negative pressure. Oecologia 126: 457-461.

Hallgren WS, Pitman AJ. 2000. The uncertainty in simulations by a Global Biome Model (BIOME3) to alternative parameter values. Global Change Biology 6: 483-495.

Hanson PJ, Todd DE, Amthor JS. 2001. A six-year study of sapling and large-tree growth and mortality responses to natural and induced variability in precipitation and throughfall. Tree Physiology 21: 345358. 
Holbrook NM, Zwieniecki MA. 2005. Vascular transport in plants. Amsterdam, The Netherlands: Elsevier.

Houghton RA. 1994. The worldwide extent of land-use change. Bioscience 44: 305-313.

Iglesias A, Rosenzweig C, Pereira D. 2000. Agricultural impacts of climate change in Spain: developing tools for a spatial analysis. Global Environmental Change 10: 69-80.

Iglesias A, Garrote L, Flores F, Moneo M. 2007. Challenges to manage the risk of water scarcity and climate change in the Mediterranean. Water Resources Management 21: 775-788.

IPCC 2007. Climate Change 2007: The physical science basis - 4AR. Geneva, Switzerland: The Intergovernmental Panel on Climate Change.

Jackson RB, Caldwell MM. 1993. The scale of nutrient heterogeneity around individual plants and its quantification with geostatistics. Ecology 74: 612-614.

Jose S, Williams R, Zamora D. 2006. Belowground ecological interactions in mixed-species forest plantations. Forest Ecology and Management 233: 231-239.

Junghans U, Polle A, Duchting P, Weiler E, Kuhlman B, Gruber F, Teichmann T. 2006. Adaptation to high salinity in poplar involves changes in xylem anatomy and auxin physiology. Plant, Cell and Environment 29: 1519-1531.

Kajimoto T, Osawa A, Matsuura Y, Abaimov AP, Zyryanova OA, Kondo K, Tokuchi N, Hirobe M. 2007. Individual-based measurement and analysis of root system development: Case studies for Larix gmelinii trees growing on the permafrost region in Siberia. Journal of Forest Research 12: 103-112.

Karnosky DF. 2003. Impacts of elevated atmospheric $\mathrm{CO}_{2}$ on forest trees and forest ecosystems: knowledge gaps. Environment International 29: 161-169.

Keddy PA. 1989. Competition. London: Chapman and Hall.

Kellomäki S, Karjalainen T, Mohren F, Lapveteläinen T. 2000. Expert assessments of the likely impacts of climate change on forests and forestry in Europe. Joensuu, Finland: European Forestry Institute.

Kräuchi N, Kienast F. 1993. Modelling subalpine forest dynamics as influenced by a changing environment. Water, Air, and Soil Pollution 68: 185-197.

Kunstmann H, Schneider K, Forkel R, Knoche R. 2004. Impact analysis of climate change for an Alpine catchment using high resolution dynamic downscaling of ECHAM4 time slices. Hydrology and Earth System Sciences 8: 1030-1044.

Leuschner C, Hertel D, Schmid I, Koch O, Muhs A, Hölscher D. 2004. Stand fine root biomass and fine root morphology in old-growth beech forests as a function of precipitation and soil fertility. Plant and Soil 258: 43-56.

Lindenmayer D, Franklin JF. 2002. Conserving forest biodiversity: A comprehensive multiscaled approach. London, UK: Island press.

Lionnello P, Malanotte-Rizzoli P, Boscolo R. 2006. Mediterranean climate variability. Amsterdam, The Netherlands: Elsevier.

Liu XP, Kozovits AR, Grams TEE, Blaschke H, Rennenberg H, Matyssek R. 2004. Competition modifies effects of enhanced ozone/carbon dioxide concentrations on carbohydrate and biomass accumulation in juvenile Norway spruce and European beech. Tree Physiology 24: 1045-1055.

Lloyd-Hughes B, Saunders MA. 2002. A drought climatology for Europe. International Journal of Climatology 22: 1571-1592.

Lloret F, Peñuelas J, Estiarte M. 2004. Experimental evidence of reduced diversity of seedlings due to climate modification in a Mediterranean-type community. Global Change Biology 10: 248-258.

Łomnicki A. 1980. Regulation of population-density due to individual-differences and patchy environment. Oikos 35: 185-193.

Lovisolo C, Secchi F, Nardini A, Salleo S, Buffa R, Schubert A. 2007. Expression of PIP1 and PIP2 aquaporins is enhanced in olive dwarf genotypes and is related to root and leaf hydraulic conductance. Physiologia Plantarum 130: 543-551. 
Lukac M, Calfapietra C, Godbold DL. 2003. Production, turnover and mycorrhizal colonization of root systems of three Populus species grown under elevated $\mathrm{CO}_{2}$ (POPFACE). Global Change Biology 9: $838-848$.

Luo Y, Su B, Currie WS, Dukes JS, Finzi A, Hartwig U, Hungate B, McMurtrie RE, Oren R, Parton WJ, Pataki DE, Shaw MR, Zak DR, Field CB. 2004. Progressive nitrogen limitation of ecosystem responses to rising atmospheric carbon dioxide. Bioscience 54: 731-739.

Mahall BE, Callaway RM. 1991. Root communication among desert shrubs. Proceedings of the National Academy of Sciences 88: 874-876.

Maherali H, DeLucia EH. 2000. Interactive effects of elevated $\mathrm{CO}_{2}$ and temperature on water transport in ponderosa pine. American Journal of Botany 87: 243-249.

Maherali H, Pockman WT, Jackson RB. 2004. Adaptive variation in the vulnerability of woody plants to xylem cavitation. Ecology 85: 2184-2199.

Maherali H, Moura CF, Caldeira MC, Willson CJ, Jackson RB. 2006. Functional coordination between leaf gas exchange and vulnerability to xylem cavitation in temperate forest trees. Plant, Cell and Environment 29: 571-583.

Martínez-Vilalta J, Piñol J. 2002. Drought-induced mortality and hydraulic architecture in pine populations of the NE Iberian Peninsula. Forest Ecology and Management 161: 247-256.

Maseda PH, Fernández RJ. 2006. Stay wet or else: Three ways in which plants can adjust hydraulically to their environment. Journal of Experimental Botany 57: 3963-3977.

Meinzer FC. 2002. Co-ordination of vapour and liquid phase water transport properties in plants. Plant, Cell and Environment 25: 265-274.

Mencuccini M. 2003. The ecological significance of long-distance water transport: Short-term regulation, long-term acclimation and the hydraulic costs of stature across plant life forms. Plant, Cell and Environment 26: 163-182.

Mills D. 1989. Differential response of various tissues of Asparagus officinalis to sodium chloride. Journal of Experimental Botany 40: 485-491.

Nambiar EKS, Sands R. 1993. Competition for water and nutrients in forests. Canadian Journal of Forest Research 23: 1955-1968.

Nardini A, Pitt F. 1999. Drought resistance of Quercus pubescens as a function of root hydraulic conductance, xylem embolism and hydraulic architecture. New Phytologist 143: 485-493.

Newman EI. 1973. Competition and diversity in herbaceous vegetation. Nature 244: 310 .

Norby RJ, Wullschleger SD, Gunderson CA, Johnson DW, Ceulemans R. 1999. Tree responses to rising $\mathrm{CO}_{2}$ in field experiments: Implications for the future forest. Plant, Cell and Environment 22: 683-714.

Norby RJ, DeLucia EH, Gielen B, Calfapietra C, Giardina CP, King JS, Ledford J, McCarthy HR, Moore DJP, Ceulemans R, de Angelis P, Finzi AC, Karnosky DF, Kubiske ME, Lukac M, Pregitzer KS, Scarascia-Mugnozza GE, Schlesinger WH, Oren R. 2005. Forest response to elevated $\mathrm{CO}_{2}$ is conserved across a broad range of productivity. Proceedings of the National Academy of Sciences 102: 18052-18056.

Olson RJ, Scurlock JMO, Prince SD, Zheng DL, Johnson KR. 2001. NPP multi-biome: Global primary production data initiative products. Data set. Oak Ridge, TN, USA: Oak Ridge National Laboratory Distributed Active Archive Centre.

Oren R, Ellsworth DS, Johnsen KH, Phillips N, Ewers BE, Maier C, Schafer KVR, McCarthy H, Hendrey G, McNulty SG, Katul GG. 2001. Soil fertility limits carbon sequestration by forest ecosystems in a $\mathrm{CO}_{2}$-enriched atmosphere. Nature 411: 469-472.

Pan Z, Christensen JH, Arritt RW, Gutowski WJ, Takle ES, Otieno F. 2001. Evaluation of uncertainties in regional climate change simulations. Journal of Geophysical Research - Atmospheres 106: 17735-17751.

Parrish JAD, Bazzaz FA. 1976. Underground niche separation in successional plants. Ecology 57: 1281-1288.

Passioura JB. 1988. Water transport in and to roots. Annual Review of Plant Physiology and Plant Molecular Biology 39: 245-265. 
Peltzer DA, Wilson SD, Gerry AK. 1998. Competition intensity along a productivity gradient in a lowdiversity grassland. The American Naturalist 151: 465-476.

Petit RJ, Hampe A, Cheddadi R. 2005. Climate changes and tree phylogeography in the Mediterranean. Taxon 54: 877-885.

Pigott CD, Pigott S. 1993. Water as a determinant of the distribution of trees at the boundary of the Mediterranean zone. Journal of Ecology 81: 557-566.

Rajaniemi TK. 2003. Evidence for size asymmetry of belowground competition. Basic and Applied Ecology 4: 239-247.

Richards RA, Passioura JB. 1989. A breeding program to reduce the diameter of the major xylem vessel in the seminal roots of wheat and its effect on grain-yield in rain-fed environments. Australian Journal of Agricultural Research 40: 943-950.

Riestenberg MM, Sovonickdunford S. 1983. The role of woody vegetation in stabilizing slopes in the Cincinnati area, Ohio. Geological Society of America Bulletin 94: 506-518.

Robinson D, Hodge A, Griffiths BS, Fitter AH. 1999. Plant root proliferation in nitrogen-rich patches confers competitive advantage. Proceedings of the Royal Society of London - Series B 266: 431-435.

Rowell DP. 2005. A scenario of European climate change for the late twenty-first century: seasonal means and interannual variability. Climate Dynamics 25: 837-849.

Roy J, Garnier E, Jackson LE. 1987. Response of two perennial grasses to water availability in different habitats related to successional change Mediterranean climate conditions. Plant response to stress. In: Tenhunen JD, Catarino FM, Lange OL, Oechel WC, eds. Functional analysis in Mediterranean ecosystems. Berlin, Germany: Springer, 175-190.

Santiago LS, Goldstein G, Meinzer FC, Fisher JB, Machado K, Woodruff D, Jones T. 2004. Leaf photosynthetic traits scale with hydraulic conductivity and wood density in Panamanian forest canopy trees. Oecologia 140: 543-550.

Schenk HJ. 2006. Root competition: beyond resource depletion. Journal of Ecology 94: 725-739.

Schwinning S, Weiner J. 1998. Mechanisms determining the degree of size asymmetry in competition among plants. Oecologia 113: 447-455.

Secchi F, Lovisolo C, Schubert A. 2007. Expression of OePIP2.1 aquaporin gene and water relations of Olea europaea twigs during drought stress and recovery. Annals of Applied Biology 150: 163-167.

Shao G, Yan X, Bugmann H. 2003. Sensitivities of species compositions of the mixed forest in eastern Eurasian continent to climate change. Global and Planetary Change 37: 307-313.

Shumway DL, Steiner KC, Abrams MD. 1991. Effects of drought stress on hydraulic architecture of seedlings from five populations of Green ash. Canadian Journal of Botany 69: 2158-2164.

Sperry JS, Adler FR, Campbell GS, Comstock JP. 1998. Limitation of plant water use by rhizosphere and xylem conductance: results from a model. Plant, Cell and Environment 21: 347-359.

Spiecker H. 1999. Overview of recent growth trends in European forests. Water, Air and Soil Pollution 116: 33-46.

Stephenson NL. 1990. Climatic control of vegetation distribution: the role of the water balance. American Naturalist 135: 649-669.

Thomas SC, Weiner J. 1989. Including competitive asymmetry in measures of local interference in plant populations. Oecologia 80: 349-355.

Tyree MT, Zimmermann MH. 2003. Xylem structure and the ascent of sap. Stuttgart, Germany: Springer.

Van Lear DH, Kapeluck PR. 1995. Above- and below-stump biomass and nutrient content of a mature Loblolly pine plantation. Canadian Journal of Forest Research 25: 361-367.

Weiner J, Wright DB, Castro S. 1997. Symmetry of below-ground competition between Kochia scoparia individuals. Oikos 79: 85-91.

Welden CW, Slauson WL, Ward RT. 1988. Competition and abiotic stress among trees and shrubs in Northwest Colorado. Ecology 69: 1566-1577.

Willson CJ, Jackson RB. 2006. Xylem cavitation caused by drought and freezing stress in four cooccurring Juniperus species. Physiologia Plantarum 127: 374-382. 
Wilson JB. 1988. Shoot competition and root competition. Journal of Applied Ecology 25: 279-296.

Wilson SD, Tilman D. 1993. Plant competition and resource availability in response to disturbance and fertilization. Ecology 74: 599-611.

Winkel T, Payne W, Renno JF. 2001. Ontogeny modifies the effects of water stress on stomatal control, leaf area duration and biomass partitioning of Pennisetum glaucum. New Phytologist 149: 71-82.

Zandersen M, Termansen M, Jensen FS. 2007. Evaluating approaches to predict recreation values of new forest sites. Journal of Forest Economics 13: 103-128.

Ziemer RR. 1978. Soil moisture and groundwater recharge under a mixed conifer forest. TransactionsAmerican Geophysical Union 59: 275. 
Chapter 2

\section{DROUGHT-INDUCED CHANGES IN AXIAL CONDUCTIVITY AND} VULNERABILITY TO EMBOLISM IN ROOTS OF TWO BROADLEAVED TREE SPECIES WITH CONTRASTING DROUGHTTOLERANCE 


\subsection{ABSTRACT}

Theory predicts that fine roots may be particularly weak elements in the hydraulic system of the plant due to elevated cavitation risk and high drought-induced mortality, thereby acting as 'fuses' in the hydrologic soil-plant-atmosphere continuum which protect the plant from further turgor loss and plant-wide xylem cavitation. We tested this hypothesis by investigating specific conductivity $\left(\mathrm{k}_{\mathrm{s}}\right)$ of fine and coarse root (i.e. axial conductivity per root cross-sectional area) and the degree of embolism in the root xylem of saplings and mature trees of drought-sensitive European beech (Fagus sylvatica L.) and relatively drought-tolerant Sessile oak (Quercus petraea (MATT.) LIEBL.) that were exposed to experimental water shortage.

Fine and coarse roots of both species were much more vulnerable to cavitation (water potentials causing $50 \%$ conductivity loss, $\Psi_{\text {PLC50 }}:-0.3$ to $\left.-0.5 \mathrm{MPa}\right)$ than shoots $(-2$ to $-3 \mathrm{MPa}$ ). Mature beech and oak trees had 3 to 15 times higher $\mathrm{k}_{\mathrm{s}}$ values of their smalldiameter roots than saplings, indicating a large increase in root specific conductivity with age. However, fine roots $(<2 \mathrm{~mm}$ in diameter) and coarse roots $(>2 \mathrm{~mm})$ differed not significantly in $\mathrm{k}_{\mathrm{s}}$. In oak, drought led to an increase in root $\mathrm{k}_{\mathrm{s}}$, which contrasts with shoots where conductivity generally decreased. However, a decrease in root conductivity was found in severely drought-stressed beech saplings and adult trees, which supports the view of oak being more drought-tolerant than beech.

We conclude that small-diameter roots of beech and oak with their height cavitation susceptibility are much more drought-sensitive than shoots. However, drought-adapted tree species such as Quercus petraea seem to be capable of partly compensating for drought-induced root conductivity losses by increasing root $\mathrm{k}_{\mathrm{s}}$. 


\section{$2.2 \quad$ INTRODUCTION}

Drought limits tree growth not only in arid environments but also in temperate oceanic regions such as Central Europe. For example, stem diameter growth of Fagus sylvatica L., the most important tree species of the natural forest vegetation, is primarily dependent on sufficient rainfall in the lowlands of Central Europe (Ellenberg 1996, Dittmar et al. 2003). Regional models of future climate change predict an increasing frequency and severity of exceptional summer droughts and heatwaves in various parts of Central Europe, in particular in sub-continental and continental regions (Wetherald and Manabe 2002, IPCC 2007). Further, summer rainfall has already decreased in certain areas of Germany during the past 100 years, as, for example, in the state of Lower Saxony (DWD 2007). Less rainfall together with higher summer temperatures and elevated evaporative demand will increase soil water deficits and drought exposure. Therefore, the adaptability to water shortage may decide about the growth potential and vitality of trees in a future warmer climate even under a temperate oceanic climate (Hanson and Welzin 2000).

Studies concerning plant adjustment to drought have highlighted the importance of adaptational changes in the plant conducting system to maximize water uptake and to reduce water deficits (Sperry et al. 1998, 2002, Ladjal et al. 2005). Plastic responses of the xylem with respect to hydraulic conductivity and vulnerability to cavitation under altered water supply may be a key trait of the drought response of trees and other plants. Various studies have emphasized differences in hydraulic properties among tree species (Whitehead and Jarvis 1981, Tyree and Zimmermann 2003). Moreover, previous work has shown that xylem properties of different plant species and plant organs can differ widely in their adaptability to environmental stresses and their susceptibility to cavitation (Martínez-Vilalta et al. 2002, Maherali et al. 2006). However, surprisingly few comparisons of plants of the same species or ecotypes grown under contrasting moisture regimes exist. Our knowledge is particularly limited with respect to the hydraulic adaptation of root systems in mature forest stands (Cinnirella et al. 2002, Leuschner et al. 2004a) even though increasing empirical evidence is accumulating showing that root system conductance plays a crucial role for water flux control in the soil-plantatmosphere continuum (Passioura 1988, Trillo and Fernández 2005). 
Experiments on root hydraulic conductivity usually measure total conductivity of root branches, thereby including both radial and axial conductivity (Kolb et al. 1996). Root radial conductivity is thought to be orders of magnitude smaller than axial conductivity (Sands et al. 1982). However, Hacke et al. (2000) demonstrated a good agreement between whole-plant water use and axial conductivity of woody plants during drought stress, suggesting that differences in root radial resistance across sites either become negligible during drought, or parallel the change in axial resistance. The path length of radial water flow is much less than axial length, indicating the importance of axial conductivity especially in large woody plants (Sperry et al. 2002, Addington et al. 2006). Moreover, meta-xylem differentiation in growing roots can be slow (Staubin et al. 1986, Vercambre et al. 2002); hindering longitudinal water transport especially in the finest roots (Doussan et al. 1998). For a better understanding of root system functioning, measurements of root axial conductance are urgently needed, especially with an emphasis on variations related to environmental stress and tree age under field conditions (Maseda and Fernández 2006).

We studied the axial conductivity, the occurrence of embolism and the vulnerability to embolism in fine root and coarse roots of mature trees and saplings of Fagus sylvatica L. and Quercus petraea (MATT.) LIEBL. which were exposed to experimental summer drought. Diffuse-porous Fagus is the most competitive tree species in large parts of Central Europe under conditions of ample moisture supply (Ellenberg 1996; Leuschner et al. 2001). In contrast, Quercus petraea has a higher tolerance of summer droughts (Backes and Leuschner 2000, Raftoyannis and Radoglou 2002), but is outcompeted by Fagus in most non-water limited environments (Brockmann et al. 1987, Aranda et al. 2000). Thus, these two tree species exemplify the trade-off between a species' ability to cope with drought stress, and high growth rates under more favourable soil water regimes (Orians and Solbrig 1977, Fotelli et al. 2001).

This paper reports on a combined field manipulation and pot study with mature trees and saplings of Fagus sylvatica and Quercus petraea which investigated the adaptability of the hydraulic system of fine and coarse roots to moderate and severe drought stress. We tested the hypotheses that (i) root specific conductivity decreases upon drought stress, (ii) fine roots are more vulnerable to cavitation than roots with larger diameters, (iii) root systems of mature trees and saplings differ in their adaptability to soil drought, and (iv) the root systems of Quercus are better adapted to drought stress 
than those of Fagus. Axial conductivities of sapling shoots were studied for comparison as well.

\subsection{MATERIAL ANd Methods}

\section{Study sites and plant material}

Saplings and mature trees of Fagus sylvatica L. (European beech) and Quercus petraea (MATT.) LiEBL. (Sessile oak) were investigated in their response to experimental drought between April 2004 and September 2006.

The study on mature trees was conducted in an unmanaged mixed oak-beech forest located in the diluvial lowlands of Lower Saxony (NW Germany) in the Lüneburger Heide at $115 \mathrm{~m}$ a.s.1. close to the village of Unterlüß (52 $83^{\prime} \mathrm{N}, 10^{\circ} 26^{\prime} \mathrm{E}$; Table 2.1).

Table 2.1 Structural characteristics of the mixed oak-beech forest at Unterlüß (NW Germany).

\begin{tabular}{lccccc}
\hline & $\begin{array}{c}\text { Age of dominant } \\
\text { trees [yrs] }\end{array}$ & $\begin{array}{c}\text { Stem den- } \\
\left.\text { sity*[ha }{ }^{-1}\right]\end{array}$ & $\begin{array}{c}\text { Tree height } \\
{[\mathbf{m}]}\end{array}$ & $\begin{array}{c}\text { Stem basal } \\
\text { area } \\
{\left[\mathbf{m}^{\mathbf{2}} \mathbf{h a}^{-\mathbf{1}}\right]}\end{array}$ & $\begin{array}{c}\text { Leaf area } \\
\text { index } \\
{\left[\mathbf{m}^{\mathbf{2}} \mathbf{~ m}^{-\mathbf{2}}\right]}\end{array}$ \\
\hline Fagus & 120 & 176 & 30 & 15.2 & 3.3 \\
Quercus & 200 & 44 & 28 & 12.3 & 1.6 \\
Stand total & - & 220 & - & 27.5 & 4.6 \\
\hline
\end{tabular}

*all trees $>10 \mathrm{~cm} \mathrm{dbh}$

Fagus and Quercus trees show a patchy distribution in the stand with monospecific groups of beech or oak. Except for saplings of the two tree species, no herbaceous layer does exist. The climate is humid sub-oceanic (annual means: $8.1^{\circ} \mathrm{C}, 801 \mathrm{~mm}$ precipitation). The cumulative precipitation during the 30-month experimental period was $1675 \mathrm{~mm}$, which is $350 \mathrm{~mm}$ below the long-term precipitation mean (H. Meesenburg, Northwest German Forest Research Station, unpublished). The soil is a spodo-dystric cambisols with a thick (mean depth of $7.2 \mathrm{~cm}$ ) and highly acidic $\left(\mathrm{pH}_{\mathrm{KCl}}\right.$ : 2.6-3.0) organic layer (Leuschner 2002). Medium-grained sand is the dominant size fraction of the sediment (40-60\% of dry mass) while the clay content is very low $(<5 \%)$.

Four plots $(8 \mathrm{~m} \times 8 \mathrm{~m})$ were chosen for study, two in Fagus- and two in Quercusdominated parts of the forest. The stands on the four plots had a closed canopy with 
comparable tree densities and tree height, and showed no signs of soil disturbance by wild boar. The plots were fenced. Each one Fagus and one Quercus plot was equipped with a below-canopy roof (treatment $\mathrm{D}_{\text {Sev. }}$ ), while the two other plots served as a control with ambient rainfall (Ctrl). The control and the roofed plot of each tree species lay adjacent to each other, while the paired Fagus and Quercus plots were about $130 \mathrm{~m}$ distant to each other. The roofs had a size of $11 \mathrm{~m}$ x $11 \mathrm{~m}$, situated about $2 \mathrm{~m}$ above the ground. They consisted of a permanent timber-frame construction, covered with removable transparent PVC plates. Eight of the nine supporting pillars were placed outside the plot, the central pillar was carefully dug into the soil inside the plot to a depth of $50 \mathrm{~cm}$. Rainfall was collected with gutters and channelled away.

The roofs were operated in three consecutive summers (2004 to 2006) from mid/end of June until end of September (i.e. 13-14 weeks per year) to simulate severe summer droughts as they occur occasionally in dry years in the region. From end of September to mid of June, the roofs were opened and ambient rainfall reached the $\mathrm{D}_{\mathrm{Sev}}$. plots in a similar intensity as the control plots. Volumetric soil water content was recorded once per month in all four plots with a mobile TDR probe (Trime FM2, Imko, Ettlingen, Germany) at six randomly selected locations per plot at a depth of $0-16 \mathrm{~cm}$. Since the three summers differed in rainfall, soil water depletion was high in the summer 2004, but less severe in the summers 2005 and 2006 (Table 2.2).

Table 2.2 Soil moisture content (vol\%) during the summer months in the surface layers $(0-16 \mathrm{~cm})$ of the control plots $(\mathrm{Ctrl})$ and roofed plots (Severe drought, $\mathrm{D}_{\mathrm{Sev}}$ ) in the Unterlüß forest (mean of $n$ TDR measurements $\pm \mathrm{SE})$.

\begin{tabular}{|c|c|c|c|c|c|c|}
\hline \multirow[b]{2}{*}{ Year } & \multirow[b]{2}{*}{ Month } & \multirow[b]{2}{*}{$n$} & \multicolumn{2}{|c|}{ Fagus } & \multicolumn{2}{|c|}{ Quercus } \\
\hline & & & Ctrl & $\mathbf{D}_{\text {Sev. }}$ & Ctrl & $\mathbf{D}_{\text {Sev. }}$ \\
\hline \multirow[t]{4}{*}{2004} & June & 64 & $15.3 \pm 0.4$ & $8.2 \pm 0.2$ & $14.5 \pm 0.7$ & $14.7 \pm 0.5$ \\
\hline & July & 6 & $18.8 \pm 1.7$ & $5.8 \pm 0.1$ & $20.5 \pm 2.3$ & $8.8 \pm 0.7$ \\
\hline & August & 6 & $11.3 \pm 1.0$ & $6.7 \pm 0.5$ & $15.1 \pm 2.1$ & $8.6 \pm 0.3$ \\
\hline & September & 6 & $18.9 \pm 0.3$ & $5.8 \pm 0.4$ & $14.8 \pm 0.5$ & $9.1 \pm 0.4$ \\
\hline \multirow[t]{4}{*}{2005} & June & 6 & $27.9 \pm 2.0$ & $27.9 \pm 2.0$ & $27.9 \pm 1.8$ & $28.1 \pm 2.2$ \\
\hline & July & 6 & $23.7 \pm 1.1$ & $20.7 \pm 1.3$ & $24.9 \pm 2.0$ & $18.9 \pm 2.0$ \\
\hline & August & 6 & $21.6 \pm 0.9$ & $12.1 \pm 2.0$ & $22.2 \pm 2.0$ & $13.5 \pm 1.2$ \\
\hline & September & 6 & $18.7 \pm 1.2$ & $10.4 \pm 0.7$ & $18.8 \pm 2.0$ & $10.1 \pm 1.8$ \\
\hline \multirow[t]{4}{*}{2006} & June & 6 & $26.8 \pm 2.4$ & $27.1 \pm 1.4$ & - & - \\
\hline & July & 6 & $13.4 \pm 0.9$ & $17.3 \pm 1.5$ & $14.6 \pm 1.1$ & $16.1 \pm 1.7$ \\
\hline & August & 6 & $25.5 \pm 1.4$ & $11.1 \pm 1.0$ & $27.1 \pm 1.9$ & $13.8 \pm 2.1$ \\
\hline & September & 6 & $19.2 \pm 1.5$ & $9.0 \pm 2.0$ & $18.0 \pm 1.2$ & $12.2 \pm 0.9$ \\
\hline
\end{tabular}


In general, soil water content at $0-16 \mathrm{~cm}$ depth was lower by 5 to $15 \mathrm{vol} \%$ in the two roof plots than in the control plots in the period July to September of the three years. Although the throughfall patterns under the oak-beech forest canopy revealed a certain heterogeneity in space, we detected no significant differences in mean summer soil water content between the two control plots (beech and oak), nor between the beech and oak drought plots (see Table 2.2).

Temperature measurements with iButton sensors (DS1921, Maxim, Sunnyvale, USA) revealed no differences between control and roofed plots with respect to air temperature. The soil temperature at $7 \mathrm{~cm}$ depth was marginally reduced by $0.5-1.0 \mathrm{~K}$ beneath the roofs during the summer months (June-August, data not shown). In addition, the soil of the Quercus plots was by $0.5-1.0 \mathrm{~K}$ colder than that in the Fagus plots. For minimizing soil compaction, mobile wooden footbridges were used to access the inner plot sections.

The experiment with ninety 4-yr-old Fagus saplings and ninety 5-yr-old Quercus saplings took place at the Experimental Botanical Garden of the University of Göttingen, Germany $\left(51^{\circ} 56^{\prime} \mathrm{N}, 09^{\circ} 96^{\prime} \mathrm{E}\right)$. Beech and oak acorns were collected in close proximity of the Unterlüß stand by the Forest Seed Centre of Lower-Saxony (Munster-Oerrel, Germany) and were planted at a tree nursery (Forestry office Göhrde, Lower Saxony, Germany). At the age of 4 (beech) or 5 (oak) years, saplings of similar size were selected from this culture in early April 2004 and individually planted in 45-1 pots, filled with nutrient-poor medium-grained quartz sand. The field capacity of the sandy substrate was about $9-10$ vol\% of water.

The potted beech and oak saplings (180 pots in total) were grown for three summers from April 2004 to September 2006 outdoor next to a mobile, transparent polycarbonate roof equipped with a rain sensor; the roof automatically covered the plants when rain fell. Thus, the plants grew under the local microclimate (mean annual temperature: $8.7^{\circ} \mathrm{C}$ ) while precipitation and soil moisture could be controlled. We applied three soil water treatments, severe drought $\left(\mathrm{D}_{\mathrm{Sev}}\right.$, mean volumetric soil water content $3 \%$ ), moderate drought $\left(\mathrm{D}_{\text {Mod. }}, 6 \mathrm{vol} \%\right)$ and a well-watered control (Ctrl, 9 vol\%). Each treatment consisted of 30 replicates, i.e. pots. From October to May, all pots were watered to field capacity. Soil water content in the pots was controlled by TDR measurements every second day. Water content was used to calculate the required amount of water needed to meet target soil moisture. For simulating realistic radiation regimes as they prevail in the forest understory shade nets (Type 9021, Wunderlich, Osterode, Ger- 
many) were mounted over the culture, which reduced radiation to about $55 \%$ of incident PPFD. The 180 pots were placed in a randomized block design. Twice per year, in April and September, the plants were fertilized with $500 \mathrm{ml}$ solution made of a commercial NPK-fertilizer (1\% Hakaphos blau, Compo, Münster, Germany). A contact insecticide against aphids (0.1\% Spruzit, Neudorff, Emmerthal, Germany) was applied once a year.

\section{Measurement of hydraulic conductivity}

We measured axial hydraulic conductivity in fine and coarse roots and also in shoots of the saplings in the Botanical Garden, and in fine and coarse roots of the mature trees in the mature stand applying the protocol given by Sperry et al. (1988; see Fig. A 1).

In the sapling experiment, roots and shoots were sampled at the end of the 13 to 14 -wk drought periods end of September 2005 and 2006. Fifteen to 56 fine and coarse root samples and 12-17 shoot samples were investigated per tree species and soil moisture treatment. The samples were obtained by first cutting off the sapling stems under water. The shoot segments had a minimum length of $20 \mathrm{~cm}$ (diameter: 5.0-9.0 mm). The root system was carefully cleaned from soil, and cut under water into several coarse root branches with attached fine roots. These root branches had a length of $\geq 12 \mathrm{~cm}$ (fine root diameters: 0.7-2.0 mm, coarse root diameters: 2.0-6.0 mm). In the forest, fine and coarse roots of beech and oak trees were selected by random in the organic layer and identified by species according to the colour and morphology of the root cortex (see Leuschner et al. 2001). Branch root systems $\geq 12 \mathrm{~cm}$ length were cut, transferred immediately to polyethylene bags filled with cold water and transported to the laboratory, where they were stored at $4^{\circ} \mathrm{C}$ until measurement. For measuring axial hydraulic conductivity in the root and shoot segments, gravity-induced flow with pressure differences of 6-7 $\mathrm{kPa}$ per $5 \mathrm{~cm}$ was used. We used deionised, degassed water containing a sodiumsilver-chloride complex $\left(16 \mu \mathrm{g} \mathrm{l}^{-1} \mathrm{Ag}, 8 \mathrm{mg} \mathrm{l}^{-1} \mathrm{NaCl}\right.$, Micropur, Katadyn, Wallisellen, Switzerland) to prevent long-term decline in conductivity. Prior to measurement, the solution was passed through a $0.2 \mu \mathrm{m}$ membrane filter (Maxi Capsule, Pall, New York, USA). Immediately before measurement, the samples were cut to a length of $5 \mathrm{~cm}$ and mounted under water on the tubing system. The exact length and proximal and distal diameters of the segments were measured with a precision-calliper after the conductivity measurements. The maximum length of the investigated root segments was determined by root morphology, i.e. the occurrence of root sections without ramifications. The length of shoot segments was chosen accordingly to allow for comparisons. We 
consider the possibility that in a few cases (probably less than 5\%) bilaterally truncated vessels may have resulted in a slight overestimation of shoot axial conductivity (see Cochard and Tyree 1990, Hacke and Sauter 1995). In a first measurement of hydraulic conductivity, a flow period of $5 \mathrm{~min}$ was allowed to give actual conductivity. The water passing through the segments was collected quantitatively at the distal end of the segment in pre-weighed plastic cups filled with cellulose. Subsequently, the root or shoot segment was flushed for $5 \mathrm{~min}$ at a pressure difference of $0.12 \mathrm{MPa}$ in order to remove air bubbles from the vessels. Afterwards, a second measurement was conducted to determine maximum axial conductivity in the unblocked xylem. Flushing and subsequent flow measurements were repeated at least twice to approach maximum conductivity values. Hydraulic conductivity $\left(\mathrm{k}_{\mathrm{h}}\right)$ was expressed in the unit $\mathrm{kg} \mathrm{m} \mathrm{MPa}{ }^{-1} \mathrm{~s}^{-1}$ which gives the mass flow rate $\left[\mathrm{kg} \mathrm{s}^{-1}\right]$ of the solution through the shoot or root segment relative to the pressure gradient $\left[\mathrm{MPa} \mathrm{m}^{-1}\right]$. Specific conductivity $\left[\mathrm{k}_{\mathrm{s}}, \mathrm{m}^{2} \mathrm{MPa}^{-1} \mathrm{~s}^{-1}\right]$ was calculated by dividing $\mathrm{k}_{\mathrm{h}}$ by the root cross-sectional area $\left[\mathrm{m}^{2}\right]$. To quantify the degree of vessel cavitation (embolism), the difference between actual conductivity and maximal conductivity was expressed as percentage of maximum conductivity (Sperry et al. 1988). Because the saplings investigated in the second or third year (2005 and 2006) showed no differences in hydraulic conductivity $k_{h}$ (data not shown), the data of the two years were pooled.

\section{Detection of vulnerability to cavitation}

We used the air-injection method after Sperry and Saliendra (1994; see Fig. A 2) to conduct an experimental analysis of the vulnerability of the root xylem to cavitation. Sample preparation was similar to the procedure described for the measurement of hydraulic conductivity. However, vulnerability curves were only established for the fine and coarse roots of the sapling experiment at the end of the second drought period (end of September 2005), comparing the control (Ctrl) and severely droughted ( $\left.\mathrm{D}_{\text {Sev. }}\right)$ treatments $(n=5-11)$. For comparison, two roots per species of the moderately droughtstressed treatment $\left(\mathrm{D}_{\text {Mod. }}\right)$ were investigated as well. Root segments of 1.0 to $3.2 \mathrm{~mm}$ in diameter and $12 \mathrm{~cm}$ in length were placed in a self-constructed pressure chamber with two opposite openings where the root endings protruded. Shallow notches (depth: $0.1-0.2 \mathrm{~mm}$ ) were cut into the opposite side of the root to allow air entering into the root xylem. The proximal end was attached to the tube of the hydraulic conductivity measurement system (see above), equipped with an additional air vent to prevent the 
intrusion of air into the tube (Fig. A 2). Prior to the first measurement, the roots were flushed with degassed water for $5 \mathrm{~min}$ at a pressure of $0.1 \mathrm{MPa}$ in order to remove air bubbles from the vessels. Hydraulic conductance was then measured at a pressure difference of about $8 \mathrm{kPa}$, with air pressure inside the chamber held at about $0.1 \mathrm{MPa}$ to prevent leakage of solution from the root into the chamber. The solution pouring out of the distal root end was collected quantitatively in plastic cups filled with cellulose. After the initial measurement, air pressure inside the chamber was increased stepwise to 0.25 , $0.50,0.75,1.00,1.25,1.50,2.00, \ldots 4.50 \mathrm{MPa}$. In each step, pressure was held constant for $10 \mathrm{~min}$. After pressurization, the pressure was released to $0.1 \mathrm{MPa}$ before conductance was remeasured. Hydraulic conductance was calculated as the average of three one-minute readings during steady flow. Exposure of the segment to progressively higher air pressures continued until hydraulic conductance had dropped to less than $95 \%$ of the initial value. By this procedure, vulnerability curves were established for control (Ctrl) and severely drought-stressed ( $\left.\mathrm{D}_{\text {Sev. }}\right)$ saplings of Fagus and Quercus by plotting the percentage of remaining hydraulic conductivity against the applied air pressure which is thought to be equal to xylem water potential (Jarbeau et al. 1995, Alder et al. 1996). The water potential resulting in a $50 \%$ loss of conductivity ( $\left.\Psi_{\mathrm{PLC} 50}\right)$ was calculated for saplings of the $\mathrm{Ctrl}, \mathrm{D}_{\mathrm{Mod}}$ and $\mathrm{D}_{\mathrm{Sev}}$. treatments, and plotted against root cross-sectional area $(n=33)$.

\section{Statistical analysis}

All data sets were tested for Gaussian distribution with a Shapiro-Wilk test. We used a non-parametric Kruskal-Wallis $\mathrm{H}$ test to detect significant differences in conductivity or embolism among different age classes, species, organs (fine roots, coarse roots), soil moisture treatments or harvest dates. Because conductivity and cavitation data were found to be not significantly different between the two harvests (2005 and 2006) in the sapling experiment, the data were pooled. A Scheffé test was used to test for significant differences among the treatments in specific conductivity, degree of shoot embolism, and root $\Psi_{\mathrm{PLC50}}$ values. All calculations were conducted with SAS version 9.1 (SAS Institute, Cary, USA). The criteria of Velleman and Hoaglin (1981) were applied to identify outliers in those data sets that were plotted as box-whisker plots. Linear and non-linear regressions were calculated with the program Xact 8.03 (SciLab, Hamburg, Germany). 


\subsection{RESULTS}

We found a large variability in specific conductivity $\mathrm{k}_{\mathrm{s}}$ (axial hydraulic conductivity related to cross-sectional area) of fine roots and coarse roots of the same tree species and soil moisture treatment. In the majority of samples investigated, certain roots had 4 to 10 -fold higher $\mathrm{k}_{\mathrm{s}}$ values than the mean of the respective samples (see crosses marking outliers in Fig. 2.1).
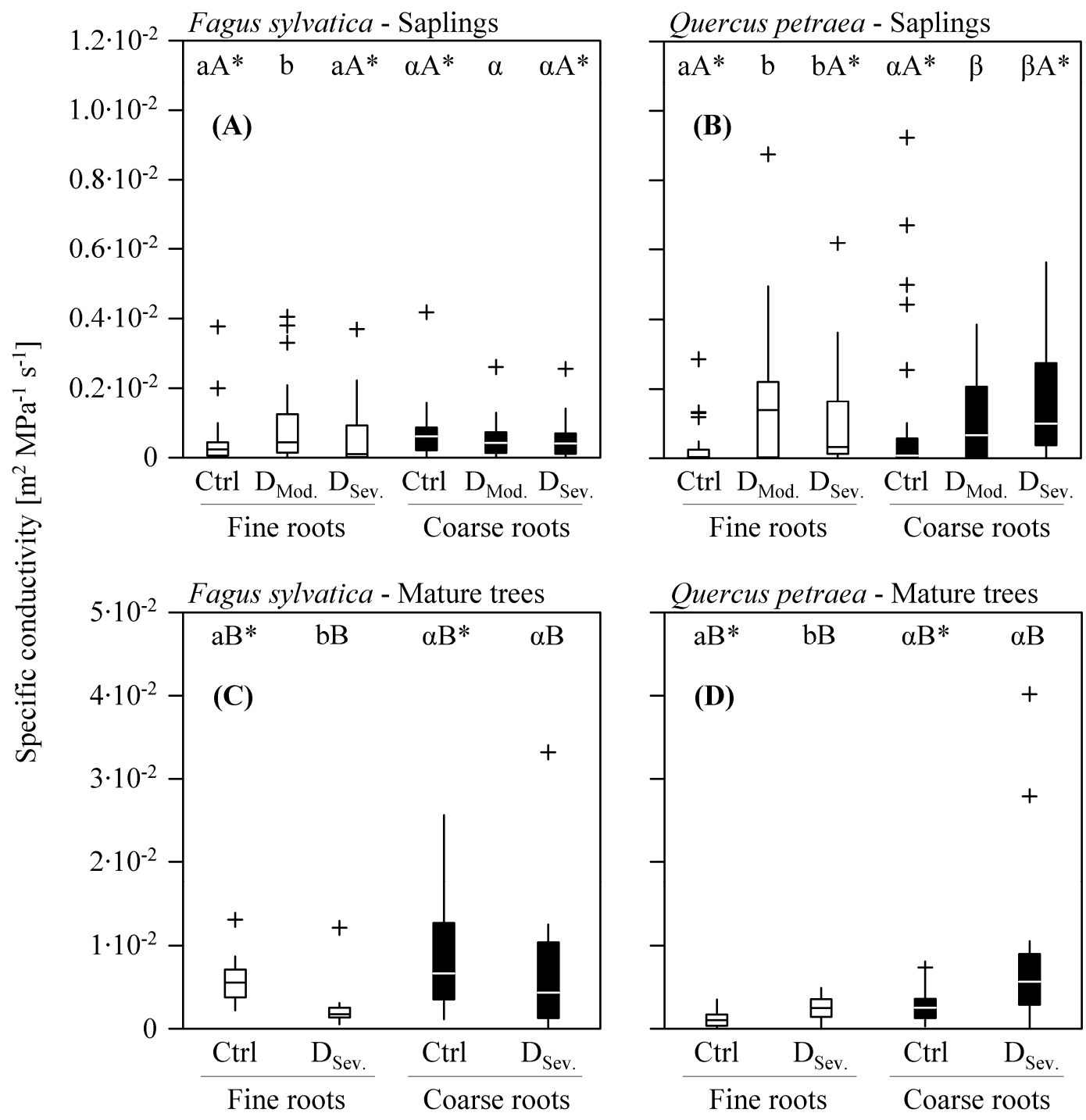

Fig. 2.1 Specific conductivity $\left(\mathrm{k}_{\mathrm{s}}\right)$ of fine roots (diameter $\left.\mathrm{d} \leq 2 \mathrm{~mm}\right)$ and coarse roots $(\mathrm{d}=2-6 \mathrm{~mm})$ of saplings (Fig. 2.1a,b) and mature trees (Fig. 2.1c,d) of Fagus sylvatica (Fig. 2.1a,c) and Quercus petraea (Fig 2.1b,d) in three soil moisture treatments [well-watered Control (Ctrl), moderate drought stress $\left(\mathrm{D}_{\text {Mod. }}\right)$ and severe drought stress $\left.\left(\mathrm{D}_{\text {Sev. }}\right)\right]$. Box-plots design represents the median (horizontal line), 25 and 75\% percentiles (box limits), and 5 and 95\% percentiles (bars). Outside values (see Statistical analyses) are plotted as + symbols. Significant differences in root conductivities within a moisture treatment are indicated by different lower case letters, significant differences between age stages by capitals, and significant differences between species are marked by asterisks (Kruskal-Wallis H test, $\mathrm{P}<0.05$, sample sizes are given in Table 2.3). 
This large variability was observed in fine roots (investigated diameters: $0.7-2.0 \mathrm{~mm}$ ) and coarse roots $(2.0-6.0 \mathrm{~mm})$ of both the 5 to $7-\mathrm{yr}$-old saplings and the mature trees. In general, no systematic differences in $\mathrm{k}_{\mathrm{s}}$ existed between these two root diameter classes in the same treatment; however, coarse roots tended to have higher average specific conductivities than fine roots in both species in the drought treatment conducted in the forest (Fig. 2.1c,d).

Table 2.3 Mean specific conductivity $\left(\mathrm{k}_{\mathrm{s}}\right)$ and degree of embolism in fine roots (diameter $\mathrm{d}=0.7-2 \mathrm{~mm}$ ) and coarse roots $(\mathrm{d}=2-6 \mathrm{~mm})$ of saplings and mature trees of Fagus sylvatica and Quercus petraea after being exposed to two or three different soil moisture treatments. Treatments were Control (Ctrl), moderate drought stress $\left(\mathrm{D}_{\mathrm{Mod}}\right)$, and severe drought stress $\left(\mathrm{D}_{\text {Sev. }}\right)$, see text. Significant differences in the degree of embolism between the soil moisture treatments within an age class are indicated by different Latin lower case letters (fine roots) or different lower case Greek letters (coarse roots). Significant differences between fine roots and coarse roots within a given age class are marked by different capital letters, and significant differences between the two species by asterisks (Kruskal-Wallis $\mathrm{H}$ test, $\mathrm{P}<0.05$, mean $\pm \mathrm{SE}$, sample size $=n$ ). Significant differences between specific conductivities $\left(\mathrm{k}_{\mathrm{s}}\right)$ are indicated in Fig. 2.1.

\begin{tabular}{|c|c|c|c|c|c|}
\hline \multirow{2}{*}{$\begin{array}{l}\text { Organ } \\
\text { Fagus - Saplin }\end{array}$} & \multirow[t]{2}{*}{ Treatment } & \multirow[t]{2}{*}{$n$} & \multirow[t]{2}{*}{$\begin{array}{c}\mathrm{k}_{\mathrm{s}} \\
{\left[10^{-3} \mathrm{~m}^{2} \mathrm{MPa}^{-1} \mathrm{~s}^{-1}\right]}\end{array}$} & \multicolumn{2}{|c|}{ Degree of embolism [\%] } \\
\hline & & & & & \\
\hline \multirow{3}{*}{ Fine roots } & Ctrl & 46 & $0.42 \pm 0.10$ & $36.0 \pm 4.4$ & $\mathrm{aA}$ \\
\hline & $\mathrm{D}_{\text {Mod. }}$ & 30 & $0.86 \pm 0.21$ & $40.0 \pm 5.8$ & $\mathrm{aA}$ \\
\hline & $\mathrm{D}_{\text {Sev. }}$ & 48 & $0.54 \pm 0.12$ & $45.1 \pm 4.9$ & $\mathrm{aA}$ \\
\hline \multirow[t]{3}{*}{ Coarse roots } & $\mathrm{Ctrl}$ & 40 & $0.68 \pm 0.11$ & $37.3 \pm 4.3$ & $\alpha \mathrm{A}$ \\
\hline & $\mathrm{D}_{\text {Mod. }}$ & 24 & $0.55 \pm 0.12$ & $38.5 \pm 7.4$ & $\alpha \mathrm{A}$ \\
\hline & $D_{\text {Sev. }}$ & 49 & $0.50 \pm 0.07$ & $33.0 \pm 4.0$ & $\alpha \mathrm{A}$ \\
\hline \multicolumn{6}{|c|}{ Fagus - Mature trees } \\
\hline \multirow[t]{2}{*}{ Fine roots } & $\mathrm{Ctrl}$ & 9 & $6.09 \pm 1.14$ & $17.6 \pm 4.1$ & $\mathrm{aA}$ \\
\hline & $D_{\text {Sev. }}$ & 11 & $2.70 \pm 0.97$ & $33.3 \pm 9.3$ & $\mathrm{aA}$ \\
\hline \multirow[t]{2}{*}{ Coarse roots } & Ctrl & 15 & $8.73 \pm 1.73$ & $4.0 \pm 1.3$ & $\alpha \mathrm{B}$ \\
\hline & $D_{\text {Sev. }}$ & 10 & $7.51 \pm 3.13$ & $14.4 \pm 6.7$ & $\alpha A^{*}$ \\
\hline \multicolumn{6}{|c|}{ Quercus - Saplings } \\
\hline \multirow[t]{3}{*}{ Fine roots } & $\mathrm{Ctrl}$ & 38 & $0.29 \pm 0.09$ & $39.1 \pm 5.4$ & $\mathrm{aA}$ \\
\hline & $\mathrm{D}_{\text {Mod. }}$ & 15 & $1.81 \pm 0.62$ & $39.4 \pm 10.1$ & aA \\
\hline & $\mathrm{D}_{\text {Sev. }}$ & 28 & $1.09 \pm 0.27$ & $41.1 \pm 6.2$ & aA \\
\hline \multirow[t]{3}{*}{ Coarse roots } & Ctrl & 56 & $0.76 \pm 0.23$ & $36.4 \pm 4.0$ & $\alpha \mathrm{A}$ \\
\hline & $\mathrm{D}_{\text {Mod. }}$ & 39 & $1.07 \pm 0.20$ & $42.3 \pm 5.2$ & $\alpha \mathrm{A}$ \\
\hline & $\mathrm{D}_{\text {Sev. }}$ & 32 & $1.55 \pm 0.27$ & $46.2 \pm 6.9$ & $\alpha \mathrm{A}$ \\
\hline \multicolumn{6}{|c|}{ Quercus - Mature trees } \\
\hline \multirow[t]{2}{*}{ Fine roots } & $\mathrm{Ctrl}$ & 14 & $1.21 \pm 0.28$ & $20.8 \pm 6.7$ & $\mathrm{aA}$ \\
\hline & $D_{\text {Sev. }}$ & 12 & $2.46 \pm 0.43$ & $36.7 \pm 9.3$ & $\mathrm{aA}$ \\
\hline \multirow[t]{2}{*}{ Coarse roots } & Ctrl & 10 & $2.96 \pm 0.76$ & $10.5 \pm 5.3$ & $\alpha \mathrm{A}$ \\
\hline & $D_{\text {Sev. }}$ & 11 & $9.95 \pm 3.79$ & $46.3 \pm 10.9$ & $\beta A^{*}$ \\
\hline
\end{tabular}


Large and significant differences in $\mathrm{k}_{\mathrm{s}}$ existed between roots of the saplings and of the mature trees with the latter showing about 3 to 15 times larger root $k_{\mathrm{s}}$ values than 5 to 7 -yr-old saplings. The large increase in root $\mathrm{k}_{\mathrm{s}}$ from juvenile to mature trees was not only found in the well-watered control but persisted in the drought treatments.

The specific conductivity of fine roots of Fagus and Quercus saplings increased significantly when reared for two or three summers under moderate drought stress (D $\mathrm{D}_{\text {Mod.; }}$ Fig. 2.1a,b, Table 2.3). For Quercus, this was also true when exposed to severe drought ( $\mathrm{D}_{\text {Sev. }}$, Fig. 2.1b), which contrasts with Fagus saplings where fine root $\mathrm{k}_{\mathrm{s}}$ was on average lower in plants subjected to severe drought than in plants growing under moderate drought (Fig. 2.1a). Unlike Quercus, coarse roots of Fagus saplings showed changes in $\mathrm{k}_{\mathrm{s}}$ neither after moderate nor after severe drought. In Quercus, large (and mostly significant) increases in specific conductivity were observed in fine and coarse roots of drought stressed trees as compared to the well-watered control. Such an adaptive response in root axial conductivity was found in both saplings and mature trees of Quercus (Fig. 2.1b,d). In contrast, specific conductivity of fine roots of adult Fagus trees was significantly lower after drought, whereas coarse roots showed no significant changes.
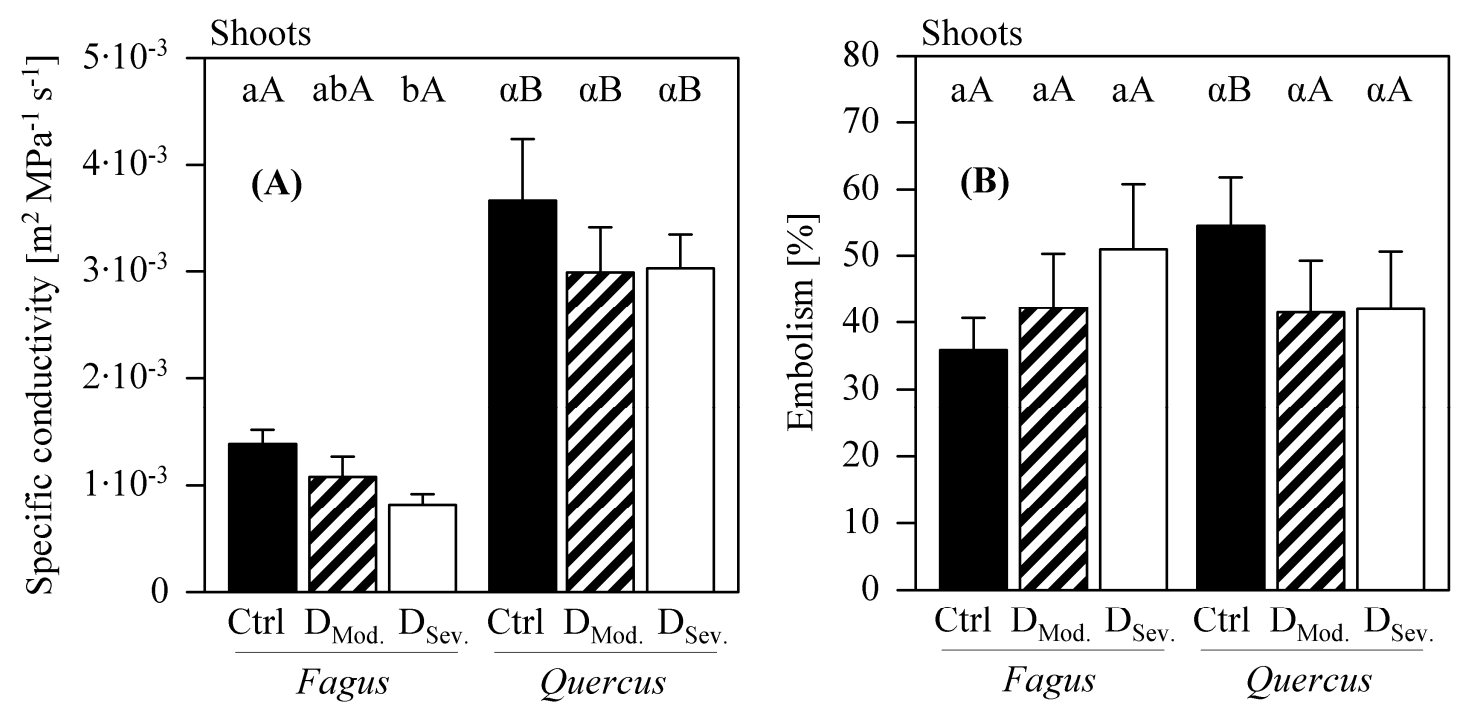

Fig. 2.2 Specific conductivities ( $\mathrm{k}_{\mathrm{s}}$, Fig. 2.2a) and degree of embolism (Fig. 2.2b) of shoots of differently droughted Fagus sylvatica and Quercus petraea saplings. Soil moisture treatments are well-watered Control $(\mathrm{Ctrl})$, moderate drought stress $\left(\mathrm{D}_{\text {Mod. }}\right)$, and severe drought stress $\left(\mathrm{D}_{\text {Sev. }}\right)$. Significant differences in shoot conductivity and embolism within species are indicated by different lower case letters, and significant differences between species by capitals (Scheffé, $\mathrm{P}<0.05$, mean $+\mathrm{SE}, n=12-17$ ).

When comparing the $\mathrm{k}_{\mathrm{s}}$ values of the two tree species, no consistent picture emerged in the different treatments and life stages. For example, the specific conductivities of fine 
and coarse roots of mature oaks were significantly lower than those of beech trees in the control treatment. In contrast, root $\mathrm{k}_{\mathrm{s}}$ after severe drought was significantly higher in roots of Quercus saplings than in Fagus saplings (Fig. 2.1a,b), whereas no significant differences could be found between drought-stressed mature trees (Fig. 2.1c,d, Table 2.3).

Contrary to our expectation, the degree of embolism in fine roots was not significantly higher in drought-stressed saplings or mature trees than in well-watered ones, even though tendencies were visible in certain cases (Table 2.3). In coarse roots of mature trees, however, embolism rate was significantly higher under drought in Quercus, and tended to do so in Fagus.

The specific conductivity of shoots of Fagus saplings was significantly lower in severely droughted than in control plants, whereas $\mathrm{k}_{\mathrm{s}}$ of Quercus shoots was only marginally reduced under drought application (Fig. 2.2a). In all treatments, the specific conductivities of Quercus shoots were significantly higher than those of Fagus shoots. With $1-4 \times 10^{-3} \mathrm{~m}^{2} \mathrm{MPa}^{-1} \mathrm{~s}^{-1}, \mathrm{k}_{\mathrm{s}}$ of shoots was considerably larger than $\mathrm{k}_{\mathrm{s}}$ of the corresponding fine roots in both species (Fig. 2.2a, Table 2.3). Fagus saplings showed a (non-significant) tendency for higher shoot embolism with increasing drought, whereas in Quercus the opposite trend appeared (Fig. 2.2b). With 35 to 55\%, the degree of embolism tended to be somewhat higher in shoots than in fine and coarse roots (Fig. 2.2b, Table 2.3).

Table 2.4 Estimates of water potentials inducing $50 \%$ loss of hydraulic conductivity ( $\left.\Psi_{\text {PLC50 }}\right)$ in smalldiameter roots of well-watered $(\mathrm{Ctrl})$ and severely drought-stressed $\left(\mathrm{D}_{\mathrm{Sev} .}\right)$ saplings of beech and oak (Scheffé, $\mathrm{p}<0.05$, mean $\pm \mathrm{SE}$, sample size $=n$ ).

\begin{tabular}{llcccc}
\hline Species & Treatment & $\boldsymbol{n}$ & Diameter [mm] & $\boldsymbol{\Psi}_{\text {PLC50 }}[\mathbf{M P a}]$ \\
\hline \multirow{2}{*}{ Fagus } & $\mathrm{Ctrl}$ & 7 & $2.83 \pm 0.53$ & $0.40 \pm 0.10$ & $\mathrm{a}$ \\
& $\mathrm{D}_{\text {Sev. }}$ & 5 & $2.28 \pm 0.52$ & $0.53 \pm 0.14$ & $\mathrm{ab}$ \\
\multirow{2}{*}{ Quercus } & $\mathrm{Ctrl}$ & 11 & $2.14 \pm 0.32$ & $0.53 \pm 0.08$ & $\mathrm{a}$ \\
& $\mathrm{D}_{\text {Sev. }}$ & 6 & $2.82 \pm 0.35$ & $0.30 \pm 0.05$ & $\mathrm{~b}$ \\
\hline
\end{tabular}

The vulnerability to cavitation, expressed as $\Psi_{\text {PLC50, was not significantly different in }}$ small-diameter roots between the two species under ample water supply (Table 2.4), but Quercus roots exhibited a significantly higher relative conductivity at a xylem pressure potential of $0.5 \mathrm{MPa}$ than Fagus roots (Fig. 2.3a,b). 


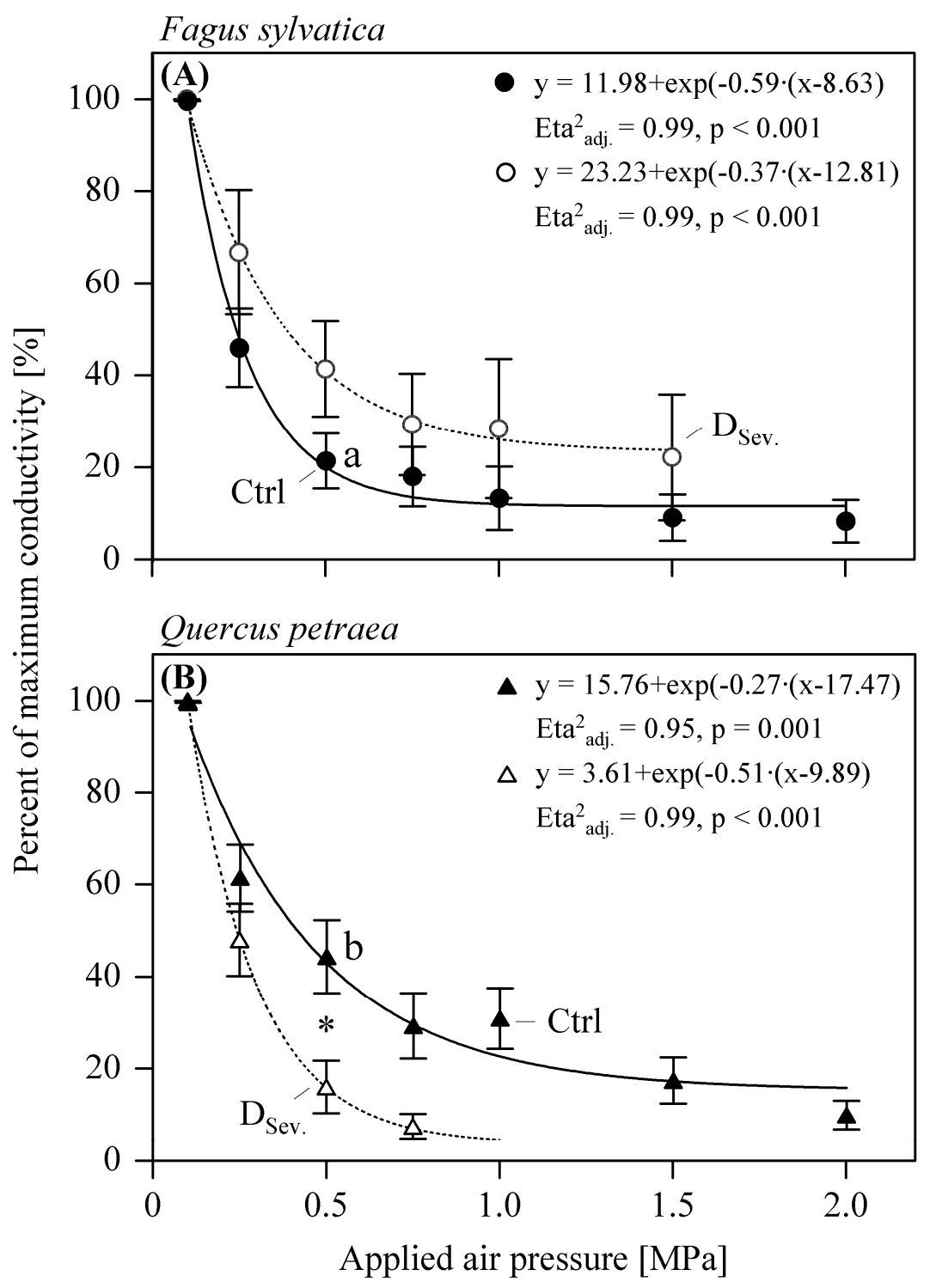

Fig. 2.3 Vulnerability curves of Fagus sylvatica (Fig. 2.3a) and Quercus petraea (Fig. 2.3b) smalldiameter roots showing percentage of maximum conductance (\%) in xylem versus the applied air pressure used in air-injection experiments. Samples originate from Control (Ctrl) and severely drought-stressed $\left(D_{\text {Sev. }}\right)$ saplings after two years (September 2005) of soil moisture treatment. Roots with diameters between 1.0 and $3.2 \mathrm{~mm}$ were used. Only conductivities with a mean $>5 \%$ of maximum conductivity are plotted. Significant differences between species are indicated by lower case letters, significant differences between soil moisture treatments are marked by asterisks (Kruskal-Wallis H test, $\mathrm{p}<0.05, \mathrm{mean} \pm \mathrm{SE}$, $n=5-11)$.

Severe drought led to a significant increase in the cavitation vulnerability $\left(\Psi_{\mathrm{PLC50}}\right)$ in Quercus roots, whereas in Fagus roots, the vulnerability tended to decrease (Table 2.4). No correlation was found between root cross-sectional area and the xylem pressure potential inducing a $50 \%$ loss of axial conductivity in roots ( $\Psi_{\mathrm{PLC} 50}$, Fig. 2.4$)$. 


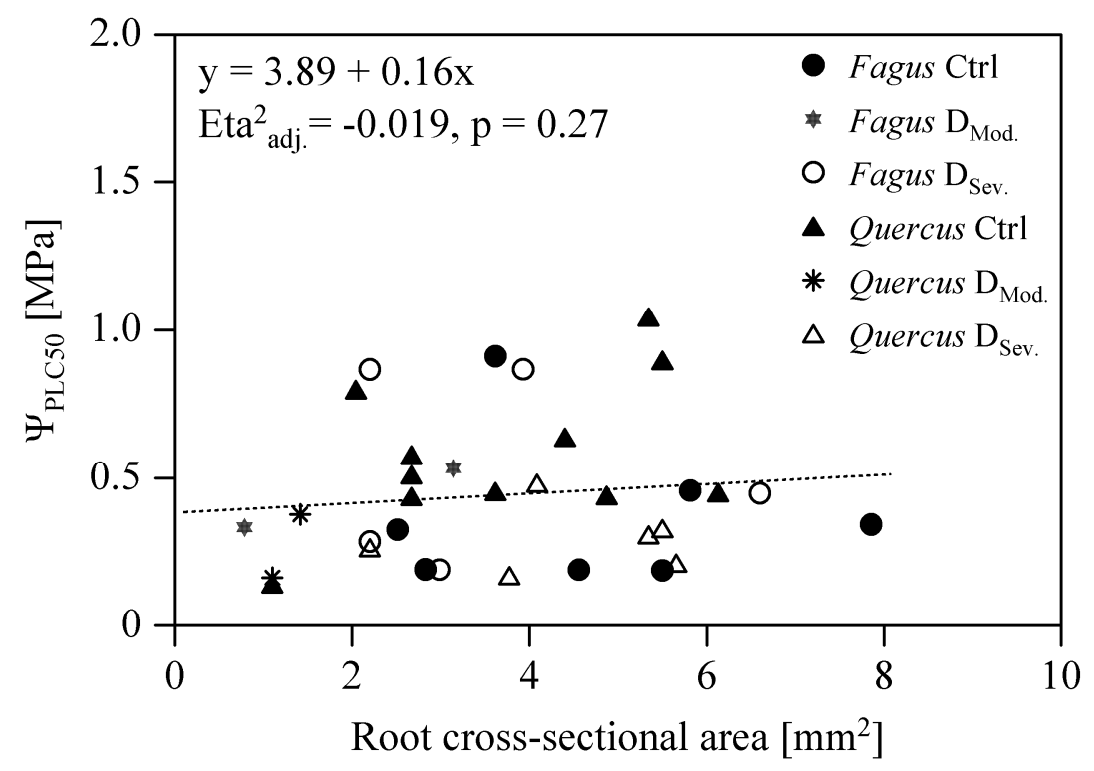

Fig. 2.4 Xylem pressure potential inducing 50\% loss of conductivity $\left(\Psi_{\mathrm{PLC} 50}\right)$ in roots of Fagus sylvatica and Quercus petraea saplings grown under three different moisture regimes as a function of root crosssectional area (Control $=\mathrm{Ctrl}$, moderately drought-stressed $=\mathrm{D}_{\text {Mod. }}$, and severely drought-stressed $=$ $\mathrm{D}_{\text {Sev. }}$ ). Plants were harvested in September 2005 after two 13 to 14-wk-long drought periods. The correlation analysis was conducted for all six data sets that were pooled $(n=33)$.

\subsection{DISCUSSION}

\section{Drought-induced changes in the hydraulic system of root and shoot}

Drought has been found to reduce not only stomatal conductance for water vapour, but also the hydraulic conductivity of roots and shoots (Tognetti et al. 1995, Nardini and Salleo 2000, Maherali et al. 2002). Such a reduction in conductivity along the plant's water conducting system may result from an increase in embolism rate, thus being temporary, or can be caused by the formation of new roots and shoots with a lower axial conductivity, then representing a lasting acclimation to drought. Whatever the cause of the conductivity reduction, it may help to reduce water loss to the atmosphere and the soil, thereby improving the plant's water balance (North and Nobel 1992, Meinzer et al. 1996, Trillo and Fernández 2005). In our sapling study, both species showed reduced specific conductivities of the shoot after moderate or severe drought treatment, which is in agreement with the results of various other studies on the drought adaptation of saplings (Tognetti et al. 1995, Searson et al. 2004). In contrast, we did not find a general reduction in axial hydraulic conductivity of the coarse or fine roots upon drought exposure. In the majority of cases, $\mathrm{k}_{\mathrm{s}}$ remained unchanged after moderate or severe drought, or even increased, as in the fine roots of moderately drought stressed beech and oak 
saplings and also in the roots of mature oak trees. Similarly, root specific conductivity increased upon drought in coarse roots of oak saplings and mature trees. A droughtinduced increase in root axial conductivity may facilitate water uptake (Nardini and Pitt 1999) by reducing the flow resistance at the water uptake side of the SPAC. Decreases in the conductivity at the loss side, i.e. at the leaf and twig levels, and maintenance or increases at the uptake side, i.e. in the root system, would be structural adaptations of plants for improving the water balance under limited water supply (Nardini and Pitt 1999). Increases in root conductivity would be particularly straightforward adaptations in plants that respond to drought with a reduction in fine root biomass and, thus, in water absorbing surface area, as was observed, for example, in beech saplings (Meier and Leuschner 2008). Our data are among the very few reports showing that droughtinduced losses in root biomass may partly be compensated by increases in root hydraulic conductivity, when drought stress is not too severe (see Fig. 2.1a). The underlying mechanisms must remain speculative, possibly including the growth of new fine roots or secondary growth with elevated axial conductivities.

Resistance to water stress-induced cavitation via air seeding depends on the surface tension of the meniscus in pores of the pit membrane that connects adjacent conduits (Jarbeau et al. 1995, Pockman and Sperry 2000). Increased resistance to cavitation was therefore thought to be accompanied by decreased pore hydraulic conductivity and, ultimately, axial hydraulic conductivity (Martínez-Vilalta et al. 2002, Sperry and Hacke 2004). Our results reveal no correlation between root axial conductivity and degree of root embolism, neither when all roots of a treatment (see Table 2.3), nor single roots are investigated (data not shown). Although Cochard et al. (1999) reported a slight decrease of safety with respect to cavitation risk with increased shoot-specific conductivity in Fagus branches, our results are indicating no trade-off between root axial conductivity and the occurrence of embolism. The apparently contrasting behaviour of aboveground and belowground organs with respect to the assumed safety-conductivity trade-off could have several reasons including an only weak relationship between pit membrane pore size and axial hydraulic conductivity in roots and perhaps so far unknown diurnal embolism repair mechanisms in roots.

Another adaptation of the root system of woody plants to soil water limitation could be the development of root branches with diverging hydraulic properties, thereby exploring the spatial heterogeneity of water reserves in the soil. Although the knowledge about the hydraulic properties of woody root systems is still scarce (Jackson et al. 2000), a grow- 
ing body of evidence suggests that root axial conductivity, and consequently water uptake rate, can differ substantially within root systems, e.g. between deep and shallow roots (Pate et al. 1995, Leuschner et al. 2004b).

In most of the root samples investigated in the sapling experiment and in the mature stand, we found a very large variation in root axial conductivity among the co-occurring roots with certain outliers showing up to ten times higher $\mathrm{k}_{\mathrm{s}}$ values than the sample mean (see Fig. 2.1, Table 2.3). Such 'high-conductivity roots' were found in the wellwatered control treatments and under drought application, but the variability of fine root axial conductivity generally increased in the root samples with two or three years of exposure to moderate or severe drought. Since individual roots or root branches are thought to act as 'physiologically autonomous units' (Shani et al. 1993), the differentiation of the root population in high-conductivity and low-conductivity roots has been postulated as a favourable adaptation particularly in soils with a high heterogeneity of soil moisture, as is typical for soils exposed to periodic drought (Göttlein and Manderscheid 1998).

\section{Do fine roots act as 'hydraulic fuses' in the SPAC?}

Peripheral organs such as leaves and fine roots have been proposed as possible weak, replaceable segments of the soil-plant-atmosphere continuum (Sperry and Saliendra 1994, Domec et al. 2004). They were thought to act as 'hydraulic fuses' of the plant during extreme droughts (Zimmermann 1983), uncoupling stems, larger roots and branches hydraulically from transpiring surfaces and drying soil, thereby allowing tissue water potential to remain lower than in the soil and preventing plant-wide xylem cavitation (Nobel and North 1992, Alder et al. 1996, Sperry and Ikeda 1997, Hacke et al. 2000). Roots could act as 'hydraulic fuses' by shedding of fine roots, as is usually suggested (Jackson et al. 2000, Chapin et al. 2004, Espeleta et al. 2004). In accordance with Alder et al. (1996), we propose cavitation to be another, potentially reversible 'hydraulic fuse' mechanism in roots. In our study, evidence for such a mechanism is provided by the very high vulnerability to cavitation ( $\Psi_{\text {PLC50: }} 0.3-0.5 \mathrm{MPa}$ ) of small-diameter roots in saplings (Fig. 2.3, Table 2.4). Previous studies on larger roots have reported much lower water potentials down to $-8.0 \mathrm{MPa}$ to induce $50 \%$ loss of conductivity (Alder et al. 1996, Martínez-Vilalta et al. 2002, Froux et al. 2005).

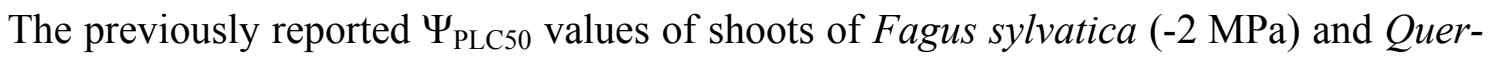
cus petraea (-3 MPa) (Cochard et al. 1992, 1999) underline the large difference in cavi- 
tation vulnerability of fine roots and shoots in these two tree species. The significant increase in the $\Psi_{\mathrm{PLC} 50}$ value from -0.53 to $-0.30 \mathrm{MPa}$ in drought stressed Quercus roots may be interpreted as a hint that small-diameter roots indeed function as a 'hydraulic fuse' in tree saplings (Table 2.4).

However, we were not able to detect a correlation between the size of small-diameter roots and $\Psi_{\text {PLC50 }}$ (Fig. 2.4). This may indicate that, over narrow size differences, other parameters such as the 'degree of maturation' or root order may be more precise indicators of vulnerability to embolism than root diameter.

The high standard errors in the embolism data of Table 2.3 indicate that co-occurring fine roots or coarse roots are differently affected by cavitation. Hacke et al. (2000) assume that the cavitation resistance of different root branches differs within root systems. Moreover, different roots of the same root system are known to show considerable differences in tissue water potential, thus holding different positions on the vulnerability curve. Embolism has been found to develop more or less gradually rather than appearing at a certain threshold (Fig. 2.3). Well-watered plants may show root cavitation not only under dry, but under moist conditions as well (Alder et al. 1996, Domec et al. 2004), a fact that is supported by our fine and coarse root data from saplings and mature trees (Table 2.3). Thus, there may be a considerable spatial variability in the degree of embolism in tree root systems even in the absence of water shortage.

\section{Do the root hydraulic properties of saplings differ from those of adult trees?}

Although it is known that young trees are often more vulnerable to drought stress than adult trees (e.g. Bolte and Roloff 1993), the knowledge about ontogenetic influences on the hydraulic system is still very limited (Mencuccini 2002). In our study, the rootspecific conductivities $\left(\mathrm{k}_{\mathrm{s}}\right)$ of adult trees of both species were 3 to 15 times higher than those of saplings (Fig. 2.1). Not only shoot-specific conductivity (Domec and Gartner 2003), but also leaf-area-based total root conductivity, which includes radial and axial conductivity, has been reported to be higher in adult than in young trees (Ito et al. 1995). One possible explanation is different progress in meta-xylem maturation in roots of young and mature trees (Staubin et al. 1986, Vercambre et al. 2002, Tyree 2003), a second one the much larger size of the roots of adult trees which implies a greater path length and diverging potential gradients in the roots. Further, the fine root:leaf biomass ratio typically increases with age (Grier et al. 1981, Vanninen et al. 1996). Moreover, a higher root-specific conductivity may be required to compensate for the increased 
hydraulic resistance in the growing path length of maturating root systems, stems and branches (West et al. 1999, Magnani et al. 2000, Addington et al. 2006).

We found a tendency (but generally not a significant trend) for adult trees to be less affected by embolism in fine and coarse roots than saplings. If valid, this apparent difference could be a consequence of the deeper extension and larger size of the root system of mature trees. By reaching deeper soil horizons with additional water sources, water may be redistributed by the plant's hydraulic system towards superficial horizons (Persson et al. 1995, Brooks et al. 2002) which could help to reduce root embolism. In support of our finding, Domec et al. (2004) also observed a higher embolism rate in young than in adult trees. Thus, a higher root embolism in juvenile trees may be one factor causing seedlings and saplings generally to be the most drought-sensitive ontogenetic stage in tree life.

Are the roots of drought-tolerant Quercus better adapted than those of Fagus?

Different genotypes or species of woody plants may differ substantially with respect to root axial conductivity (Huber 1956, Korn 2004), and vulnerability to cavitation (Domec and Gartner 2003, Alsina et al. 2007). In contrast to our hypothesis, the fine and coarse roots of ring-porous oak and diffuse-porous beech showed no systematic difference in their mean $\mathrm{k}_{\mathrm{s}}$ values. This is different in shoots and stems with Quercus showing a higher specific conductivity than Fagus (see Fig. 2.2, and Steppe and Lemeur 2007). It appears that the seasonality of vessel formation in early- and late-wood in the stem, which guarantees maximum water transport to the new leaves, is of minor relevance for the development of the hydraulic system in roots. Presumably, other factors such as soil moisture, soil density and temperature, and water potential gradients in the root system are more decisive in the control of root hydraulic conductivity.

The Central European Quercus species (Q. petraea and Q. robur) possess a number of adaptations that make them more drought-tolerant than Fagus sylvatica. Shoots of Quercus petraea generally have been found to be more resistant to cavitation than those of Fagus sylvatica (Cochard et al. 1992, 1999, Cruiziat et al. 2002), despite a higher hydraulic conductivity. Further, Quercus trees showed a higher capability of droughtinduced osmotic adjustment in the leaves and a lower sensitivity of its photosynthetic apparatus to drought than Fagus (Backes and Leuschner 2000, Dreyer et al. 2001). More important, oak stem diameter growth was found to be much less drought-sensitive than in beech (e.g. Bonn 1998). With respect to the root system, several lines of evi- 
dence support the notion that Quercus petraea is more drought-tolerant than Fagus sylvatica. In a mixed oak-beech stand, Hertel (1999) and Leuschner et al. (2001) found a pronounced increase in fine root mortality during a severe drought period in Fagus but much less on Quercus. In accordance with this observation, Quercus fine roots grew more superficially in the topsoil than those of Fagus (Leuschner et al. 2001). Our data suggest that Quercus fine and coarse roots are also capable of responding more flexibly to drought in terms of root physiology: fine and coarse roots of Quercus generally responded with an increase in $\mathrm{k}_{\mathrm{s}}$ to moderate or severe drought, while those of Fagus mostly did not. Indeed, Meier and Leuschner (2008) concluded from a hydrologic gradient study in different beech forests that water shortage leads to a reduction in stand fine root biomass, with fine roots being much more sensitive than leaves. Fagus seems not capable of a sufficient adjustment of its fine and coarse root system to drought, neither in terms of biomass maintenance, nor with respect to the provision of root hydraulic capacity for water uptake.

\subsection{CONCLUSION}

We conclude that our study provided multiple evidences of small-diameter roots functioning as fuses in the SPAC of temperate trees in a certain sense, thereby supporting our second hypothesis. However, our data do not support our first hypothesis ( $\mathrm{k}_{\mathrm{s}}$ decrease upon drought), since we found no evidence of a different adaptability of the root systems of mature trees and saplings to drought, even though $\mathrm{k}_{\mathrm{s}}$ was much higher in mature trees. The superior drought tolerance of Quercus petraea compared to Fagus sylvatica is to a large extent related to the greater plasticity and lower droughtsensitivity of the root system, with Quercus saplings revealing a better drought adaptation of the root system than Fagus especially in this highly sensitive ontogenetic stage. Further research on ontogenetic differences in the drought response of root growth and root functioning of trees is urgently needed. 


\subsection{REFERENCES}

Addington RN, Donovan LA, Mitchell RJ, Vose JM, Pecot SD, Jack SB, Hacke UG, Sperry JS, Oren R. 2006. Adjustments in hydraulic architecture of Pinus palustris maintain similar stomatal conductance in xeric and mesic habitats. Plant, Cell and Environment 29: 535-545.

Alder NN, Sperry JS, Pockman WT. 1996. Root and stem xylem embolism, stomatal conductance, and leaf turgor in Acer grandidentatum populations along a soil moisture gradient. Oecologia 105: 293-301.

Alsina MM, De Herralde F, Aranda X, Save R, Biel C. 2007. Water relations and vulnerability to embolism are not related: Experiments with eight grapevine cultivars. Vitis 46: 1-6.

Aranda I, Gil L, Pardos JA. 2000. Water relations and gas exchange in Fagus sylvatica L. and Quercus petraea (MATT.) LIEBL. in a mixed stand at their southern limit of distribution in Europe. Trees - Structure and Function 14: 344-352.

Backes K, Leuschner C. 2000. Leaf water relations of competitive Fagus sylvatica and Quercus petraea trees during 4 years differing in soil drought. Canadian Journal of Forest Research 30: 335-346.

Bolte A, Roloff A. 1993. Influence of beech standards on ground vegetation and natural regeneration. Allgemeine Forst- und Jagdzeitung 164: 97-102.

Bonn S. 1998. Dendroökologische Untersuchung der Konkurrenzdynamik in Buchen/EichenMischbeständen und zu erwartende Modifikationen durch Klimaänderungen. Tharandt, Germany: Fachrichtung Forstwissenschaften der TU Dresden, Tharandt.

Brockmann WG, Eckstein D, Aniol RW. 1987. Dendroklimatologische Untersuchungen zur Bedeutung des Produktionsfaktors Wasser für das Baumwachstum. Forstwissenschaftliches Centralblatt 106: 340-354.

Brooks JR, Meinzer FC, Coulombe R, Gregg J. 2002. Hydraulic redistribution of soil water during summer drought in two contrasting Pacific Northwest coniferous forests. Tree Physiology 22: 1107-1117.

Chapin III FS, Matson PA, Mooney HA. 2004. Principles of terrestrial ecosystems. Berlin, Germany: Springer.

Cinnirella S, Magnani F, Saracino A, Borghetti M. 2002. Response of a mature Pinus laricio plantation to a three-year restriction of water supply: structural and functional acclimation to drought. Tree Physiology 22: 21-30.

Cochard H, Tyree MT. 1990. Xylem dysfunction in Quercus - Vessel sizes, tyloses, cavitation and seasonal-changes in embolism. Tree Physiology 6: 393-407.

Cochard H, Bréda N, Granier A, Aussenac G. 1992. Vulnerability to air-embolism of three European oak species (Quercus petraea (MATT.) LIEBL., Quercus pubescens WiLlD., Quercus robur L.). Annals of Forest Science 49: 225-233.

Cochard H, Lemoine D, Dreyer E. 1999. The effects of acclimation to sunlight on the xylem vulnerability to embolism in Fagus sylvatica L.. Plant, Cell and Environment 22: 101-108.

Cruiziat P, Cochard H, Améglio T. 2002. Hydraulic architecture of trees: main concepts and results. Annals of Forest Science 59: 723-752.

DWD 2007. Klimawandel im Detail. Zahlen und Fakten zum Klima in Deutschland. Offenbach, Germany: Deutscher Wetterdienst.

Dittmar C, Zech W, Elling W. 2003. Growth variations of Common beech (Fagus sylvatica L.) under different climatic and environmental conditions in Europe - a dendroecological study. Forest Ecology and Management 173: 63-78.

Domec JC, Gartner BL. 2003. Relationship between growth rates and xylem hydraulic characteristics in young, mature and old-growth Ponderosa pine trees. Plant, Cell and Environment 26: 471-483. 
Domec JC, Warren JM, Meinzer FC, Brooks JR, Coulombe R. 2004. Native root xylem embolism and stomatal closure in stands of Douglas fir and Ponderosa pine: Mitigation by hydraulic redistribution. Oecologia 141: 7-16.

Doussan C, Vercambre G, Pagès L. 1998. Modelling of the hydraulic architecture of root systems: An integrated approach to water absorption - Distribution of axial and radial conductances in maize. Annals of Botany 81: 225-232.

Dreyer E, Le Roux X, Montpied P, Daudet FA, Masson F. 2001. Temperature response of leaf photosynthetic capacity in seedlings from seven temperate tree species. Tree Physiology 21: 223-232.

Ellenberg H. 1996. Vegetation Mitteleuropas mit den Alpen in ökologischer, dynamischer und historischer Sicht. $5^{\text {th }}$ ed. Stuttgart, Germany: Ulmer.

Espeleta JF, West JB, Donovan LA. 2004. Species-specific patterns of hydraulic lift in co-occurring adult trees and grasses in a sandhill community. Oecologia 138: 341-349.

Fotelli MN, Geßler A, Peuke AD, Rennenberg H. 2001. Drought affects the competitive interactions between Fagus sylvatica seedlings and an early successional species, Rubus fruticosus: responses of growth, water status and delta C-13 composition. New Phytologist 151: 427-435.

Froux F, Ducrey M, Dreyer E, Huc R. 2005. Vulnerability to embolism differs in roots and shoots and among three Mediterranean conifers: consequences for stomatal regulation of water loss? Trees Structure and Function 19: 137-144.

Göttlein A, Manderscheid B. 1998. Spatial heterogeneity and temporal dynamics of soil water tension in a mature Norway spruce stand. Hydrological Processes 12: 417-428.

Grier CC, Vogt KA, Keyes MR, Edmonds RL. 1981. Biomass distribution and above-ground and belowground production in young and mature Abies amabilis zone ecosystems of the Washington Cascades. Canadian Journal of Forest Research 11: 155-167.

Hacke UG, Sauter JJ. 1995. Vulnerability of xylem to embolism in relation to leaf water potential and stomatal conductance in Fagus sylvatica f. purpurea and Populus balsamifera. Journal of Experimental Botany 46: 1177-1183.

Hacke UG, Sperry J, Pittermann J. 2000. Drought experience and cavitation resistance in six shrubs from the Great Basin, Utah. Basic and Applied Ecology 1: 31-41.

Hanson PJ, Weltzin JF. 2000. Drought disturbance from climate change: response of United States forests. The Science of The Total Environment 262: 205-220.

Hertel D. 1999. The fine root system of mixed stands of European beech: structure, dynamics and interspecific competition (In German). Berlin, Germany: Cramer.

Huber B. 1956. Die Gefäßleitung. In: Ruhland W, ed. Handbuch der Pflanzenphysiologie, vol. 2. Berlin, Germany: Springer, pp. 541-582.

IPCC 2007. Climate Change 2007: The Physical Science Basis - 4AR. Geneva, Switzerland: The Intergovernmental Panel on Climate Change.

Ito S, Sakuta K, Gyokusen K. 1995. Distribution of hydraulic resistance in seedlings, sprouts and an adult tree of Pasania edulis Makino. Ecological Research 10: 143-149.

Jackson RB, Sperry JS, Dawson TE. 2000. Root water uptake and transport: using physiological processes in global predictions. Trends in Plant Science 5: 482-488.

Jarbeau JA, Ewers FW, Davis SD. 1995. The mechanism of water-stress induced embolism in two species of Chaparral shrubs. Plant, Cell and Environment 18: 189-196.

Kolb KJ, Sperry JS, Lamont BB. 1996. A method for measuring xylem hydraulic conductance and embolism in entire root and shoot systems. Journal of Experimental Botany 47: 1805-1810.

Korn S. 2004. Experimental investigation of water uptake and hydraulic properties of the root system of six European tree species (In German). PhD thesis. University of Göttingen, Germany.

Ladjal M, Huc R, Ducrey M. 2005. Drought effects on hydraulic conductivity and xylem vulnerability to embolism in diverse species and provenances of Mediterranean cedars. Tree Physiology 25: 1109-1117.

Leuschner C, Hertel D, Coners H, Büttner V. 2001. Root competition between beech and oak: a hypothesis. Oecologia 126: 276-284. 
Leuschner C. 2002. Forest succession and water resources: soil hydrology and ecosystem water turnover in early, mid and late stages of a 300-yr-long chronosequence on sandy soil. In: Dohrenbusch A, Bartsch N, eds. Forest development - Succession, environmental and forest management. Case studies. Berlin, Germany: Springer, 1-68.

Leuschner C, Coners H, Icke R. 2004a. In situ measurement of water absorption by fine roots of three temperate trees: species differences and differential activity of superficial and deep roots. Tree Physio$\operatorname{logy} 24: 1359-1367$.

Leuschner C, Hertel D, Schmid I, Koch O, Muhs A, Hölscher D. 2004b. Stand fine root biomass and fine root morphology in old-growth beech forests as a function of precipitation and soil fertility. Plant and Soil 258: 43-56.

Magnani F, Mencuccini M, Grace J. 2000. Age-related decline in stand productivity: the role of structural acclimation under hydraulic constraints. Plant, Cell and Environment 23: 251-263.

Maherali H, Williams BL, Paige KN, DeLucia EH. 2002. Hydraulic differentiation of Ponderosa pine populations along a climate gradient is not associated with ecotypic divergence. Functional Ecology 16: $510-521$.

Maherali H, Moura CF, Caldeira MC, Willson CJ, Jackson RB. 2006. Functional coordination between leaf gas exchange and vulnerability to xylem cavitation in temperate forest trees. Plant, Cell and Environment 29: 571-583.

Martínez-Vilalta J, Prat E, Oliveras I, Piñol J. 2002. Xylem hydraulic properties of roots and stems of nine Mediterranean woody species. Oecologia 133: 19-29.

Maseda PH, Fernández RJ. 2006. Stay wet or else: Three ways in which plants can adjust hydraulically to their environment. Journal of Experimental Botany 57: 3963-3977.

Meier IC, Leuschner C. 2008. The belowground drought response of European beech: fine root biomass and carbon partitioning in 14 mature stands across a precipitation gradient. Global Change Biology, in press.

Meinzer FC, Fownes JH, Harrington RA. 1996. Growth indices and stomatal control of transpiration in Acacia koa stands planted at different densities. Tree Physiology 16: 607-615.

Mencuccini M. 2002. Hydraulic constraints in the functional scaling of trees. Tree Physiology 22: $553-565$

Nardini A, Pitt F. 1999. Drought resistance of Quercus pubescence as a function of root hydraulic conductance, xylem embolism and hydraulic architecture. New Phytologist 143: 485-493.

Nardini A, Salleo S. 2000. Limitation of stomatal conductance by hydraulic traits: sensing or preventing xylem cavitation? Trees - Structure and Function 15: 14-24.

North GB, Nobel PS. 1992. Drought induced changes in hydraulic conductivity and structure in roots of Ferocactus acanthodes and Opuntia ficus indica. New Phytologist 120: 9-19.

Orians GH, Solbrig O. 1977. A cost-income model of leaves and roots with special reference to arid and semiarid areas. American Naturalist 111: 677-690.

Passioura JB. 1988. Water transport in and to roots. Annual Review of Plant Physiology and Plant Molecular Biology 39: 245-265.

Pate JS, Jeschke WD, Aylward MJ. 1995. Hydraulic architecture and xylem structure of the dimorphic root systems of South-West Australian species of Proteaceae. Journal of Experimental Botany 46: 907-915.

Persson H, Vonfircks Y, Majdi H, Nilsson LO. 1995. Root distribution in a Norway spruce (Picea abies (L.) KARST.) stand subjected to drought and ammonium-sulphate application. Plant and Soil 168/169: 161-165.

Pockman WT, Sperry JS. 2000. Vulnerability to xylem cavitation and the distribution of Sonoran desert vegetation. American Journal of Botany 87: 1287-1299.

Raftoyannis Y, Radoglou K. 2002. Physiological responses of beech and Sessile oak in a natural mixed stand during a dry summer. Annals of Botany 89: 723-730. 
Sands R, Fiscus EL, Reid CPP. 1982. Hydraulic-properties of pine and bean roots with varying degrees of suberization, vascular differentiation and mycorrhizal infection. Australian Journal of Plant Physiology 9: 559-569.

Searson MJ, Thomas DS, Montagu KD, Conroy JP. 2004. Wood density and anatomy of water-limited eucalypts. Tree Physiology 24: 1295-1302.

Shani U, Waisel Y, Eshel A, Xue S, Ziv G. 1993. Responses to salinity of grapevine plants with split root systems. New Phytologist 124: 695-701.

Sperry JS, Donnelly JR, Tyree MT. 1988. A method for measuring hydraulic conductivity and embolism in xylem. Plant, Cell and Environment 11:35-40.

Sperry JS, Saliendra NZ. 1994. Intra- and inter-plant variation in xylem cavitation in Betula occidentalis. Plant, Cell and Environment 17: 1233-1241.

Sperry JS, Ikeda T. 1997. Xylem cavitation in roots and stems of Douglas fir and White fir. Tree Physiology 17: 275-280.

Sperry JS, Hacke UG, Oren R, Comstock JP. 2002. Water deficits and hydraulic limits to leaf water supply. Plant, Cell and Environment 25: 251-263.

Sperry JS, Hacke UG. 2004. Analysis of circular bordered pit function - I. Angiosperm vessels with homogenous pit membranes. American Journal of Botany 91: 369-385.

Staubin G, Canny MJ, McCully ME. 1986. Living vessel elements in the late metaxylem of sheathed maize roots. Annals of Botany 58: 577-588.

Steppe K, Lemeur R. 2007. Effects of ring-porous and diffuse-porous stem wood anatomy on the hydraulic parameters used in a water flow and storage model. Tree Physiology 27: 43-52.

Tognetti R, Johnson JD, Michelozzi M. 1995. The response of European beech (Fagus sylvatica L.) seedlings from two Italian populations to drought and recovery. Trees - Structure and Function 9: 348-354.

Trillo N, Fernández R. 2005. Wheat plant hydraulic properties under prolonged experimental drought: Stronger decline in root-system conductance than in leaf area. Plant and Soil 277: 277-284.

Tyree MT, Zimmermann MH. 2003. Xylem structure and the ascent of sap. Stuttgart, Germany: Springer.

Tyree MT. 2003. Hydraulic properties of roots. In: de Kroon H, Visser EJW, eds. Root ecology. Berlin, Germany: Springer, 125-150.

Vanninen P, Ylitalo H, Sievanen R, Mäkelä A. 1996. Effects of age and site quality on the distribution of biomass in Scots pine (Pinus sylvestris L.). Trees - Structure and Function 10: 231-238.

Velleman PF, Hoaglin DC. 1981. The ABC's of EDA: Applications, basics, and computing of exploratory data analysis. Boston, USA: Duxbury.

Vercambre G, Doussan C, Pagès L, Habib R, Pierret A. 2002. Influence of xylem development on axial hydraulic conductance within Prunus root systems. Trees - Structure and Function 16: 479-487.

West GB, Brown JH, Enquist BJ. 1999. A general model for the structure and allometry of plant vascular systems. Nature 400: 664-667.

Wetherald RT, Manabe S. 2002. Simulation of hydrologic changes associated with global warming. Journal of Geophysical Research - Atmospheres 107: 7.1-7.15.

Whitehead D, Jarvis PG. 1981. Coniferous forest and plantations. In: Kozlowski TT, ed. Water deficits and plant growth. New York, USA: Academic Press, 49-152.

Zimmermann MH. 1983. Xylem structure and the ascent of sap. Berlin, Germany: Springer. 


\section{Chapter 3}

\section{DOES ROOT XYLEM PLASTICITY AFFECT SALT TOLERANCE?}

Boris Rewald, Christoph Leuschner, Zeev Wiesman and Jhonathan E. Ephrath 


\subsection{ABSTRACT}

Cultivation of olive (Olea europaea L.) is highly encouraged in Mediterranean countries because of its low water requirement and considerable salt tolerance, which however, varies strongly between varieties. Salt exclusion capacities of roots are known to play a significant role in salinity tolerance.

Three varieties of olive, Barnea, Arbequina and Proline, expressing different levels of salinity tolerance, were examined. Three levels of saline water were used for irrigation of mature trees. Axial conductivities and embolism rates of roots and branches were estimated by low pressure conductivity measurement. Cross-sections were analyzed with respect to xylem anatomy.

The more salt-resistant varieties Barnea and Arbequina possess lower root specific conductivities than salt-sensitive Proline. However, fine and coarse roots of the three olive varieties showed an overall increase in specific conductivity as level of salinity increased. Barnea covers twice as much of root axial conductivity with small-sized $(<10 \mu \mathrm{m})$ conduits than both other varieties.

We suggest that under severe salt stress an amplified functional differentiation in high conductivity roots and a relative high proportion of small conduits may guarantee sufficient hydraulic safety while it allows rapid water uptake from soil patches with ample water supply. The high plasticity of the root hydraulic system in the highly salt tolerant olive variety Barnea is seen as a favourable trait for water uptake in soils with heterogeneous salinity by reducing the threat of embolism in shoots. 


\subsection{INTRODUCTION}

Salinisation of agricultural soils is a world-wide problem of increasing severity, often caused by irrigation (Kozlowski 1997). In many arid and semi-arid regions, agriculture is forced to utilise saline groundwater which intensifies salinisation (Beltran 1999). Therefore, salinisation has significant economic, social, and environmental impacts world-wide (Pannell 2001). In Mediterranean countries, the cultivation of the olive (Olea europea L.) for fruit and oil production is highly encouraged (Chartzoulakis et al. 1992, Gucci et al. 1997), not least because of its considerable salt tolerance. Olive plants typically tolerate soil water salinities as high as $3-6 \mathrm{dS} \mathrm{m}^{-1}$ (FAO 1985). However, large variation in salt sensitivity exists among olive genotypes (Gucci et al. 1997). Despite a detailed understanding of salt tolerance and avoidance mechanisms on molecular and physiological levels (Flowers and Flowers 2005, Dajic 2006), and numerous experimental studies on the salt tolerance of herbaceous crops and tree seedlings, our understanding of salt tolerance mechanisms of adult trees or woody crops is still very limited (Tabatabaei 2006). Salt tolerance mechanisms on the physiological level include salt exclusion, excretion and compartimentation (Waisel 1972, Verslues et al. 2006), and are often associated with active osmotic adjustment (Tattini et al. 2006), and conservative water use (Shannon, 1997). Although roots are the first organs to be affected by salt stress (Waisel and Breckle 1987, Córdoba et al. 2004), most research on salt tolerance focussed on aboveground organs but neglected morphological and physiological responses of the roots, especially in woody plants (Demiral 2005, Junghans et al. 2006). This is astonishing because important processes of plant salt tolerance are thought to be located in the roots (Bernstein and Hayward 1958, Lacan and Durand 1995). Plasticity of the hydraulic system (Azaizeh and Steudle 1991) is still far less understood than altered growth pattern, salt-exclusion, or osmoregulation mechanisms (Carter et al. 2006). Photosynthesis and growth of plants in general, and olive trees in particular, are to a considerable degree determined by the plant's hydraulic conductance (Tyree 2003, Nardini et al. 2006) as well as by the vulnerability of xylem to cavitation (Salleo et al. 2000). Understanding the forces and resistances that control the movement of water through the soil-plant system, with special consideration of the root system, is essential in order to understand the influence of salinity on plant survival. 
In the following, we present the results of a comprehensive study on root hydraulic and root anatomical properties of three differently salt-sensitive varieties of mature olive trees. The aims of this study were to test whether salinity has a major influence on the axial conductivity and on the degree of embolism, and to relate the hydraulic properties to xylem morphology. We analysed changes in specific conductivity, degree of embolism, and morphology of fine roots, coarse roots, and branches of trees irrigated with water of different salinities.

\subsection{MATERIAL AND MethodS}

\section{Study site}

The study was conducted during December 2006 in the Ramat Negev Experimental Station located in the central Israeli Negev Desert $\left(31^{\circ} 05^{\prime} 00 " \mathrm{~N}, 34^{\circ} 41^{\prime} 03^{\prime \prime} \mathrm{E}\right.$, altitude $305 \mathrm{~m}$ a.s.1.). The soil type of this region is Typic Torrifluvent derived from loess, with a clay content of $6-8 \%\left(\mathrm{pH}_{\mathrm{KCl}}: 7.9-8.2\right)$. Maximal daily temperature is about $35^{\circ} \mathrm{C}$ during July and August, and minimal temperature is close to $5.5^{\circ} \mathrm{C}$ during January. The average annual precipitation in this area is approximately $90 \mathrm{~mm}$, falling between November and April. Three olive (Olea europea L.) varieties, Barnea, Arbequina, and Proline, were planted in 1997 in plots irrigated either by saline or fresh water. Barnea and, to a minor degree, Arbequina olive trees are known to be more tolerant to salinity (Aragüés et al. 2005, Wiesman et al. 2004) than Proline trees (Wiesman, unpublished). This conclusion is based on seven years of observation of above-ground biomass increment and fruit yield in an orchard in the Israeli Negev.

The experimental site was divided into two plots. The first plot contained the three olive varieties, arranged in rows at random order. The distance between tree individuals in a row was $3 \mathrm{~m}$, with a distance of $6 \mathrm{~m}$ between rows. Rows were either irrigated with fresh water [Control, electrical conductivity of the soil $(E C)=1.2 \mathrm{dS} \mathrm{m}^{-1}$ ], or moderately saline water (EC $4.2 \mathrm{dS} \mathrm{m}^{-1}$, moderate salinity). In a second plot (approx. $150 \mathrm{~m}$ apart), Barnea trees were irrigated with water of a higher content of $\mathrm{NaCl}$ (EC $7.5 \mathrm{dS} \mathrm{m}^{-1}$, high salinity), which was previously found to be harmful to both other varieties (Wiesman, unpublished). The second plot had the same soil characteristics and trees were planted in the same density $(3 \mathrm{~m} \times 6 \mathrm{~m})$. 
The saline water originated from local wells and was adjusted by mixing with fresh water or by adding $\mathrm{NaCl}$. The olive trees were drip-irrigated, according to estimated water losses as calculated from local pan evaporation data (class A pan evaporation: approx. $\left.2294 \mathrm{~mm} \mathrm{a}^{-1}\right)$. The average quantity of water supplied annually to the olive plots was $656 \mathrm{~mm}$. During the first three years after planting, irrigation water was supplied immediately after each rainfall event to avoid salinisation of the rhizosphere. Volumetric soil moisture at the time of harvest was $25.2 \pm 1.6 \mathrm{vol} \%$ (mean $\pm \mathrm{SE}$ ) in the Control, $24.7 \pm 1.4 \mathrm{vol} \%$ in the moderate salinity treatment, and $28.9 \pm 3.8$ in the high salinity treatment, respectively. These soil moisture levels equal the moisture content at field capacity (Oron et al. 1999). Usually twice a year, in March and November, supplements of $100 \mathrm{~mm}$ water were added in order to leach salt excesses from the rhizosphere (Wiesman et al. 2004). During the experimental period in December 2006, neither soil leaching nor precipitation events occurred at the experimental site. NPKB-fertilization was based on results of annual leaf nutrient analyses (Wiesman et al. 2004).

\section{Root and twig sampling}

Three randomly selected trees per variety and salinity treatment were sampled in December 2006 for roots and branches. Fine roots (diameter $\mathrm{d}=0.9-2 \mathrm{~mm}$ ) and coarse roots $(\mathrm{d}=2-10 \mathrm{~mm})$ were excavated at a distance of 0.1-0.2 $\mathrm{m}$ to the bole and 0.1-0.3 $\mathrm{m}$ to the next irrigation-dripper. All root segments longer than $10 \mathrm{~cm}$ were collected within the excavation (approx. $25 \mathrm{~cm}$ wide and $15 \mathrm{~cm}$ deep). Thus, 8-30 fine or coarse root segments per variety and salinity treatment were gathered in total. Twelve branches ( $d=4-6 \mathrm{~mm}, 30-40 \mathrm{~cm}$ length) per variety and treatment were collected from the same three tree individuals. The sampling took place three times at weekly intervals during mid-morning (9-11 am EET). The segments were placed in sludge-filled polyethylene bags or boxes, transported immediately to the laboratory and stored for up to 6 days at $4^{\circ} \mathrm{C}$ until measurements were carried out.

\section{Measurement of hydraulic conductivity}

Axial hydraulic conductivity in fine roots, coarse roots and branches was measured according to the protocol given by Sperry et al. (1988). In brief, a gravity-induced flow with pressure differences of $7-8 \mathrm{kPa}$ was applied to the root and branch segments. Filtered tap water $(0.25 \mu \mathrm{m})$ with a sodium-silver chloride complex $\left(16 \mu \mathrm{g}^{-1} \mathrm{Ag}\right.$, 
$8 \mathrm{mg}^{-1} \mathrm{NaCl}$, Micropur MC 1T, Katadyn, Switzerland) was used as perfusing solution to prevent long-term decline in conductivity. Before entering the root and branch segments, the solution was forced through a $0.20 \mu \mathrm{m}$ membrane filter (Maxi Capsule, Pall, USA). In the laboratory, all samples were cut under water to $5 \mathrm{~cm}$ long segments and mounted on adapters. The segment length was chosen according to data of mean vessel length $(275 \mu \mathrm{m})$ in Mediterranean tree and shrub species (Fahn et al. 1986). Two conductivity measurements were carried out: Firstly, a 5-min flow measurement was conducted with the untreated root or branch segments in order to determine 'initial hydraulic conductivity' under field conditions. The traversed solutions were collected in pre-weighed vials filled with cellulose strips. Following the initial conductivity measurement, the segments were flushed with solution for $5 \mathrm{~min}$ at a pressure gradient of $0.12 \mathrm{MPa}$ in order to remove air bubbles from the vessels. Secondly, maximum conductivity was determined by repeating the measurement and flushing procedure at least twice. Subsequently, length and diameter of the segments were determined and the samples stored in $70 \%$ ethanol. The data were expressed as hydraulic conductivity $\left(\mathrm{k}_{\mathrm{h}}, \mathrm{m}^{4} \mathrm{~s}^{-1} \mathrm{MPa}^{-1}\right)$, i.e. solution mass flow rate $\left(\mathrm{kg} \mathrm{s}^{-1}\right)$ through the segment per pressure gradient $\left(\mathrm{MPa} \mathrm{m}{ }^{-1}\right)$. Specific conductivity $\left(\mathrm{k}_{\mathrm{s}}, \mathrm{m}^{2} \mathrm{~s}^{-1} \mathrm{MPa}^{-1}\right)$ was calculated by relating $\mathrm{k}_{\mathrm{h}}$ to the cross-sectional area of the segment. A few roots had exceptionally high conductivities which met the criteria of outliers in the statistical analysis; these roots were termed 'high conductivity' roots. The difference between initial and maximum conductivity, expressed in percent of maximum conductivity, was used as a measure of the degree of embolism (Sperry et al. 1988).

\section{Anatomical analysis}

Eight fine root and eight coarse root samples per variety and salt treatment (Barnea $7.5 \mathrm{dS} \mathrm{m}^{-1}$ : 12 fine roots) were dehydrated with PEG/ethanol-series (Polyethylene glycol 2000, Carl Roth, Karlsruhe, Germany) consisting of PEG-concentrations of $25 \%$ (temperature: $55^{\circ} \mathrm{C}$, exposure period: $\left.1 \mathrm{~h}\right), 50 \%\left(58^{\circ} \mathrm{C}, 1 \mathrm{~h}\right), 75 \%\left(60^{\circ} \mathrm{C}, 1 \mathrm{~h}\right)$, and $100 \%$ PEG $2000\left(60^{\circ} \mathrm{C}, 2 \times 1 \mathrm{~h}\right)$. Finally, the samples were embedded in 100\% PEG 2000. Seven to $10 \mu \mathrm{m}$ thick cross-sections were cut with a rotation microtome (2040, Reichert-Jung, Heidelberg, Germany). The cross-sections were mounted on slides and photographed at a magnification of $80 \times$ using a light microscope (Photomikroskop III, Carl Zeiss, Germany) and a digital camera (PowerShot A620, Canon, Japan). Due to irregular vessel distribution within the stele, whole cross-sections, or at least fractions as 
large as possible $(>80 \%)$, were analysed. An object micrometer (scale resolution: $10 \mu \mathrm{m}$ ) was photographed as scale reference. Pictures (covering $\geq 80 \%$ total stele area) were analysed with ImageJ (v1.38h, http://rsb.info.nih.gov/ij) via particle analysisfunction. All conduits with lumen areas (A) smaller than $20 \mu \mathrm{m}^{2}$ and non-vessel cells (particularly from medullary rays) with lumen areas $\mathrm{A} \geq 20 \mu \mathrm{m}^{2}$ were excluded. Conduits $\left(\mathrm{A} \geq 20 \mu \mathrm{m}^{2}\right)$, which includes vessels and tracheids, were analyzed with respect to number and individual area (Core et al. 1979). Idealized radii (r) were calculated by means of lumen area $\left(A=r^{2} \pi\right)$. Mean conduit diameter, xylem total lumen area, total root cross-sectional area (TCSA), and proportion of the stele in the total root crosssection area (stele TCSA ratio) were determined. Hydraulically weighted average conduit diameter (HWCD), was calculated $\left[2 \times\left(\Sigma r^{5}\left(\Sigma r^{4}\right)^{-1}\right)\right.$; Lewis and Boose 1995] to re-

flect that vessel conductivity is proportional to the $4^{\text {th }}$ power of the vessel radius. The theoretical hydraulic conductivity $\left(\mathrm{k}_{\mathrm{h}}^{\text {theo }}, \mathrm{m}^{4} \mathrm{~s}^{-1} \mathrm{MPa}^{-1}\right)$ of segments was calculated with the Hagen-Poiseuille equation (Huber 1956). For these calculations we set the viscosity constant $\eta_{\mathrm{H} 2 \mathrm{O} / 20^{\circ} \mathrm{C}}$ to $1.00210^{-3} \mathrm{~Pa} \mathrm{~s}$ (Zwieniecki et al. 2001). The cumulative theoretical $\mathrm{k}_{\mathrm{h}}$ curves were calculated by summarizing the relative contributions of conduit diameter classes to $\mathrm{k}_{\mathrm{h}}^{\text {theo }}$.

\section{Statistical analyses}

All data sets were tested for Gaussian distribution with a Shapiro-Wilk test. We used a parametric Scheffé's multiple comparison procedure to test for significant differences in stele TCSA ratio, total xylem lumen area, and mean, hydraulically weighted and maximum conduit diameters. Comparisons of normally distributed parameters were made with three-way general linear models (GLM), testing for salinity, olive variety, and root diameter class (fine root, coarse root) and cross effects. Only at least marginally significant results $(p<0.1)$ are given. A non-parametric Mann-Whitney $U$ test was used to determine if varieties, treatments, and/or organs differed with respect to measured specific conductivity and degree of embolism. Calculations were conducted with SAS version 8.02 (SAS Institute, Cary, USA). Outliers in box plots were calculated according to Velleman and Hoaglin $\left(1981 ; \mathrm{k}_{\mathrm{s}}\right.$ value $>1.5 \times$ the interquartile range). Non-linear regressions were calculated with the program Xact 8.03 (SciLab, Hamburg, Germany). 


\subsection{RESULTS}

\section{Proportion of the stele and conduit lumen area}

Although only marginally significant (data not shown), the proportion of the stele (stele TCSA ratio) of Barnea and Arbequina fine roots tended to decrease in response to saline irrigation, while the stele TCSA ratio of Proline increased (Table 3.1; GLM result, salinity effect: $F=2.46, p=0.0937)$. Thus, the fine root stele TCSA ratio of salt resistant Barnea was significantly lower than that of salt sensitive Proline under moderate salt stress $\left(4.2 \mathrm{dS} \mathrm{m}^{-1}\right)$. No significant differences were found between stele TCSA ratios of coarse roots, whereas the root diameter class (fine root, coarse root) was significantly correlated with the stele TCSA ratio (GLM result, diameter class effect: $F=12.35$, $\mathrm{p}=0.0006$, Table 3.1).

Table 3.1 Anatomical properties [proportion of stele in total cross-sectional area- (stele TCSA ratio), mean conduit diameter, and total xylem lumen area ] of fine roots and coarse roots of three Olea europea varieties under different salinities $\left(1.2,4.2\right.$, and $\left.7.5 \mathrm{dS} \mathrm{m}^{-1}\right)$. Barnea fine roots are separated into 'normal' and high-conductivity ('HC') roots by outlier analysis (see Statistical analyses). Significant differences are indicated by different lower case letters (Scheffé, $\mathrm{p}<0.05, \operatorname{mean} \pm \mathrm{SE}, n=$ sample size).

\begin{tabular}{|c|c|c|c|c|c|c|c|c|}
\hline \multirow{2}{*}{$\begin{array}{l}\text { Olive variety } \\
\text { Fine roots }\end{array}$} & \multirow[t]{2}{*}{$\begin{array}{l}\text { Salinity } \\
{\left[\mathrm{dS} \mathrm{m}^{-1}\right]}\end{array}$} & \multirow[t]{2}{*}{$n$} & \multicolumn{2}{|c|}{$\begin{array}{c}\text { Stele TCSA ratio } \\
{[\%]}\end{array}$} & \multicolumn{2}{|c|}{$\begin{array}{l}\text { Mean conduit } \\
\text { diameter }[\mu \mathrm{m}]\end{array}$} & \multicolumn{2}{|c|}{$\begin{array}{c}\text { Total xylem } \\
\text { lumen area }[\%]\end{array}$} \\
\hline & & & & & & & & \\
\hline Barnea & 1.2 & 8 & $41.2 \pm 1.5$ & $a b$ & $8.8 \pm 0.4$ & $\mathrm{a}$ & $9.9 \pm 1.7$ & $\mathrm{a}$ \\
\hline Barnea & 4.2 & 8 & $40.4 \pm 2.2$ & $\mathrm{a}$ & $9.5 \pm 0.5$ & $\mathrm{a}$ & $11.9 \pm 1.0$ & $\mathrm{a}$ \\
\hline Barnea 'normal' & 7.5 & 6 & $31.2 \pm 2.9$ & $a b$ & $8.6 \pm 1.6$ & $\mathrm{a}$ & $11.2 \pm 5.1$ & $\mathrm{a}$ \\
\hline Barnea 'HC' & 7.5 & 4 & $41.0 \pm 4.2$ & $\mathrm{ab}$ & $21.9 \pm 5.1$ & $\mathrm{~b}$ & $33.2 \pm 6.5$ & $\mathrm{~b}$ \\
\hline Arbequina & 1.2 & 8 & $46.8 \pm 3.2$ & $a b$ & $10.5 \pm 0.4$ & $\mathrm{a}$ & $13.8 \pm 3.8$ & $\mathrm{a}$ \\
\hline Arbequina & 4.2 & 8 & $39.4 \pm 3.9$ & $a b$ & $9.5 \pm 0.6$ & $\mathrm{a}$ & $12.6 \pm 2.5$ & $\mathrm{a}$ \\
\hline Proline & 1.2 & 8 & $36.2 \pm 3.3$ & $\mathrm{ab}$ & $8.9 \pm 0.5$ & $\mathrm{a}$ & $8.7 \pm 1.9$ & $\mathrm{a}$ \\
\hline Proline & 4.2 & 8 & $49.1 \pm 4.7$ & $\mathrm{~b}$ & $9.6 \pm 0.4$ & $\mathrm{a}$ & $8.8 \pm 2.1$ & $\mathrm{a}$ \\
\hline \multicolumn{9}{|l|}{ Coarse roots } \\
\hline Barnea & 1.2 & 8 & $46.5 \pm 1.8$ & $a b$ & $10.7 \pm 0.8$ & $\mathrm{a}$ & $11.1 \pm 1.4$ & $\mathrm{a}$ \\
\hline Barnea & 4.2 & 11 & $46.4 \pm 1.1$ & $\mathrm{~b}$ & $11.2 \pm 0.3$ & $\mathrm{a}$ & $10.8 \pm 1.4$ & $\mathrm{a}$ \\
\hline Barnea & 7.5 & 8 & $43.7 \pm 3.3$ & $\mathrm{ab}$ & $11.7 \pm 0.9$ & $\mathrm{a}$ & $15.8 \pm 3.2$ & $\mathrm{ab}$ \\
\hline Arbequina & 1.2 & 8 & $46.5 \pm 5.4$ & $\mathrm{ab}$ & $11.0 \pm 0.6$ & $\mathrm{a}$ & $13.1 \pm 1.6$ & $\mathrm{a}$ \\
\hline Arbequina & 4.2 & 8 & $46.7 \pm 2.0$ & $\mathrm{ab}$ & $10.0 \pm 0.5$ & $\mathrm{a}$ & $15.5 \pm 2.4$ & $\mathrm{ab}$ \\
\hline Proline & 1.2 & 8 & $49.1 \pm 1.8$ & $\mathrm{ab}$ & $11.9 \pm 0.8$ & $\mathrm{a}$ & $12.4 \pm 1.3$ & $\mathrm{a}$ \\
\hline Proline & 4.2 & 8 & $45.7 \pm 1.3$ & $\mathrm{ab}$ & $11.2 \pm 0.5$ & $\mathrm{a}$ & $13.4 \pm 1.3$ & $\mathrm{a}$ \\
\hline
\end{tabular}


With total xylem lumen areas of $8.7 \%$ (control) and $8.8 \%\left(4.2 \mathrm{dS} \mathrm{m}^{-1}\right)$, the steles of Proline fine roots were found to contain the lowest conducting areas while the high conductivity roots of Barnea showed significantly higher xylem lumen areas under severe salt stress (Fig. 3.1, Table 3.1). Significantly increased total xylem lumen areas were found with increasing level of salinity and by including cross effects of variety and salinity (GLM results, salinity effect: $F=8.68, p=0.0003$; variety*salinity effect: $\mathrm{F}=3.53, \mathrm{p}=0.0032)$.

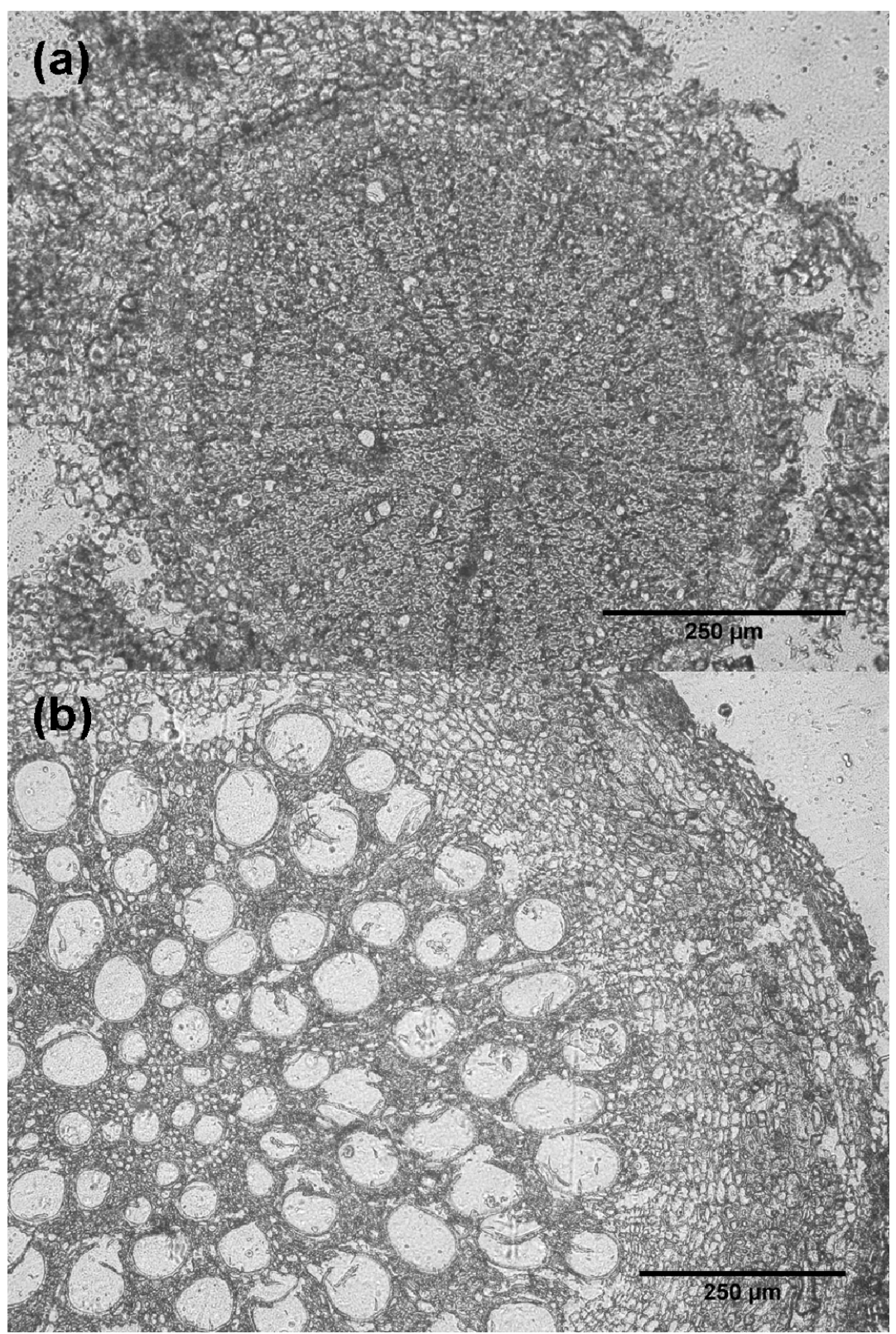

Fig. 3.1 LM-micrographs of a normal (Fig. 3.1a) and a high conductivity (Fig. 3.1b) fine root of Olea europea var. Barnea under severe salt stress $\left(7.5 \mathrm{dS} \mathrm{m}^{-1}\right)$. Scale bars represent $250 \mu \mathrm{m}$. 


\section{Xylem conduit diameter and distribution pattern}

The hydraulically weighted conduit diameter (HWCD) of Barnea fine roots under fresh water and moderately saline irrigation tended to be lower than that of Arbequina and Proline under the same conditions (Fig. 3.2). The HWCD of Barnea was significantly increased $(\mathrm{p}<0.05)$ in high conductivity roots under severe salinity $\left(7.5 \mathrm{dS} \mathrm{m}^{-1}\right.$, Figs. 3.1, 3.2a, Table 3.1).
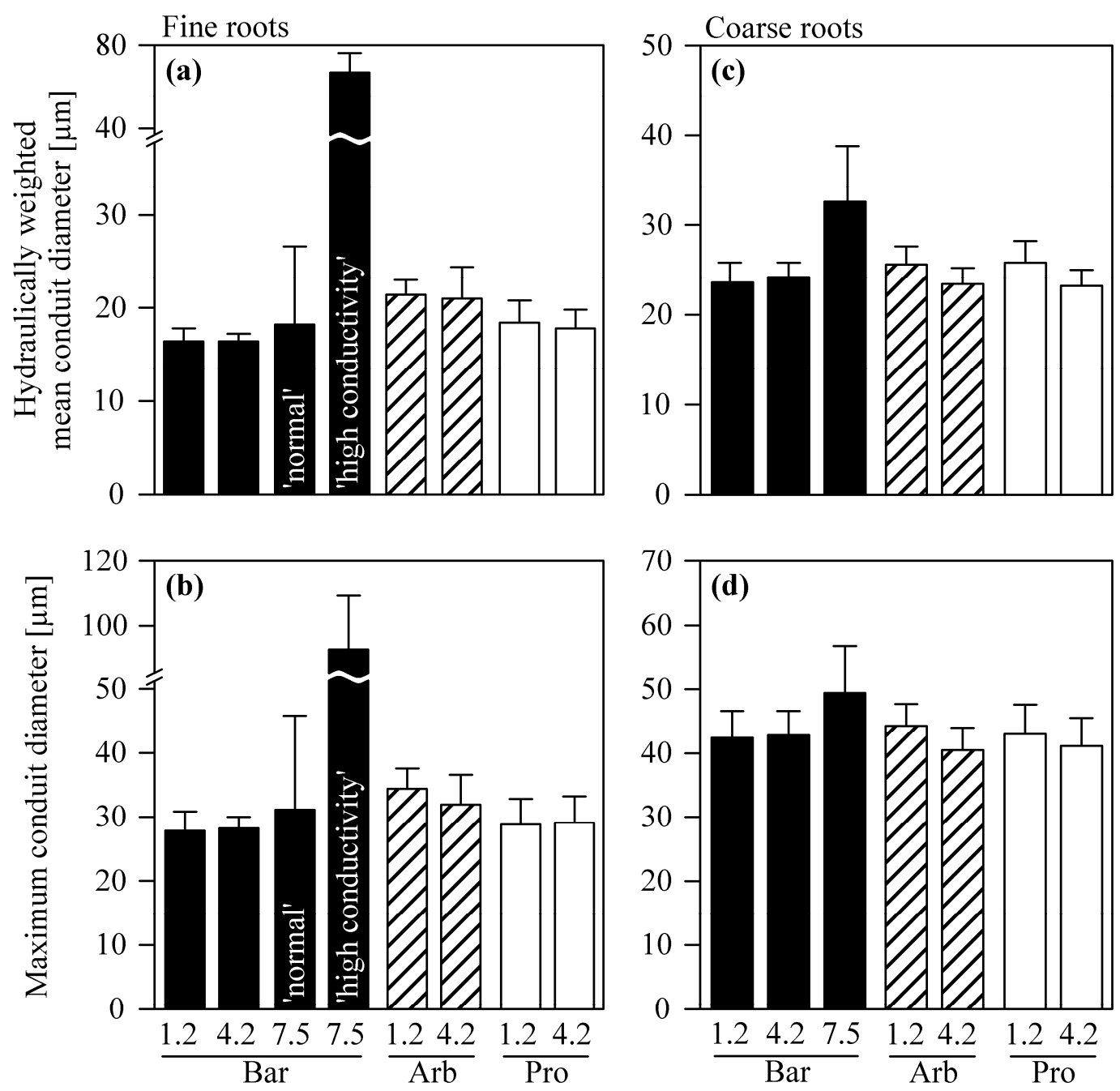

Fig. 3.2 Xylem conduit diameters in fine roots $(\mathrm{d} \leq 2 \mathrm{~mm}$, Fig. 3.2a,b) and coarse roots $(\mathrm{d}=2-10 \mathrm{~mm}$, Fig. 3.2c,d) of three Olea europea varieties [Barnea (Bar), Arbequina (Arb), and Proline (Pro)]. Conduits are tracheids and vessels. Hydraulically weighted mean conduit diameter (HWCD) is shown in Fig. 3.2a,c and maximum conduit diameter (MAXCD) in Fig. 3.2b,d. Data are presented as mean+SE $(n=4-8)$. HWCD weights the importance of the radii in proportion to the estimated hydraulic conductance of the conduits. GLM result of HWCD: salinity effect, $F=12.86, p<0.0001$. GLM results of MAXCD: salinity effect, $\mathrm{F}=7.78, \mathrm{p}=0.0007$; diameter class effect, $\mathrm{F}=6.89, \mathrm{p}=0.01$.

The mean conduit diameter, the HWCD and the MAXCD were found to be significantly influenced by salinity, thereby increasing slightly in Barnea but decreasing in both other varieties with increasing salinity (Fig. 3.2a,c; GLM result of mean conduit diameter, 
salinity effect: $F=6.21, p<0.0028$; GLM result of $H W C D$, salinity effect: $F=8.68$, $\mathrm{p}<0.0001$; GLM result of MAXCD, salinity effects: $\mathrm{F}=7.78, \mathrm{p}<0.0007$ ).

Mean diameter and hydraulically weighted conduit diameters tended to be larger in coarse roots than in fine roots (Fig. 3.2a,c, Table 3.2). This difference was statistically significant for the maximum conduit diameter (MAXCD, Fig. 3.2b,d; GLM result, diameter class effect: $F=6.89 \mathrm{p}=0.01$ ). However, the MAXCD in high-conductive Barnea fine roots $\left(7.5 \mathrm{dS} \mathrm{m}^{-1}\right)$ was found to be even larger than in coarse roots $(\mathrm{P}<0.05)$.

Table 3.2 Relative conduit diameter distributions of fine and coarse roots of the Olea europea varieties Barnea, Arbequina, and Proline at different salinity treatments (1.2, 4.2, and $\left.7.5 \mathrm{dS} \mathrm{m}^{-1}\right)$. For Barnea fine roots under severe salt stress $\left(7.5 \mathrm{dS} \mathrm{m}^{-1}\right)$, 'normal' and high conductivity ('HC') roots were distinguished by means of outlying data (see Statistical analyses, mean $\pm \mathrm{SE}, n=$ sample size).

Fraction of conduit diameter classes [\%]

$\begin{array}{lllllll}\text { Olive variety } & \begin{array}{l}\text { Salinity } \\ {\left[\mathrm{dS} \mathrm{m}^{-1}\right]}\end{array} \quad n \quad 5-10 \mu \mathrm{m} & 10-15 \mu \mathrm{m} & 15-20 \mu \mathrm{m} & 20-25 \mu \mathrm{m} & >25 \mu \mathrm{m}\end{array}$

\begin{tabular}{lrrrrrrr}
\hline Fine roots & & & & & & \\
Barnea & 1.2 & 8 & $69.3 \pm 4.8$ & $22.8 \pm 3.8$ & $6.4 \pm 1.4$ & $1.0 \pm 0.4$ & $0.4 \pm 0.2$ \\
Barnea & 4.2 & 8 & $70.1 \pm 6.2$ & $19.4 \pm 3.0$ & $7.6 \pm 2.3$ & $2.4 \pm 1.1$ & $0.4 \pm 0.3$ \\
Barnea 'normal' & 7.5 & 6 & $78.2 \pm 4.9$ & $14.4 \pm 2.1$ & $3.9 \pm 1.0$ & $1.9 \pm 1.0$ & $1.6 \pm 0.9$ \\
Barnea 'HC' & 7.5 & 4 & $53.4 \pm 4.4$ & $11.8 \pm 0.6$ & $3.5 \pm 0.6$ & $2.5 \pm 0.3$ & $28.8 \pm 3.2$ \\
Arbequina & 1.2 & 8 & $57.8 \pm 4.1$ & $21.8 \pm 2.1$ & $11.8 \pm 1.5$ & $5.5 \pm 0.7$ & $2.3 \pm 1.1$ \\
Arbequina & 4.2 & 8 & $69.3 \pm 4.8$ & $17.3 \pm 2.4$ & $7.9 \pm 2.9$ & $3.0 \pm 1.1$ & $2.0 \pm 1.0$ \\
Proline & 1.2 & 8 & $73.4 \pm 5.0$ & $18.0 \pm 3.3$ & $5.3 \pm 1.7$ & $2.2 \pm 1.0$ & $1.0 \pm 0.4$ \\
Proline & 4.2 & 8 & $62.9 \pm 2.4$ & $23.7 \pm 1.5$ & $9.6 \pm 1.6$ & $3.4 \pm 0.9$ & $1.3 \pm 0.6$ \\
Coarse roots & & & & & & & \\
Barnea & 1.2 & 8 & $61.3 \pm 5.0$ & $20.0 \pm 2.5$ & $9.1 \pm 1.7$ & $5.3 \pm 1.7$ & $3.1 \pm 1.2$ \\
Barnea & 4.2 & 8 & $57.3 \pm 3.2$ & $18.0 \pm 1.2$ & $12.7 \pm 1.4$ & $6.9 \pm 1.0$ & $3.6 \pm 1.3$ \\
Barnea & 7.5 & 8 & $64.8 \pm 4.0$ & $15.5 \pm 2.1$ & $7.3 \pm 1.0$ & $4.7 \pm 1.0$ & $7.5 \pm 2.1$ \\
Arbequina & 1.2 & 8 & $65.0 \pm 3.3$ & $15.9 \pm 2.4$ & $8.6 \pm 1.2$ & $4.9 \pm 0.6$ & $5.6 \pm 1.1$ \\
Arbequina & 4.2 & 8 & $68.5 \pm 3.1$ & $14.9 \pm 1.9$ & $8.3 \pm 1.1$ & $4.9 \pm 0.8$ & $3.5 \pm 1.4$ \\
Proline & 1.2 & 8 & $58.9 \pm 4.1$ & $22.8 \pm 1.1$ & $10.9 \pm 0.8$ & $5.4 \pm 1.0$ & $6.3 \pm 2.2$ \\
Proline & 4.2 & 8 & $55.8 \pm 2.4$ & $20.8 \pm 1.8$ & $13.3 \pm 0.8$ & $6.6 \pm 1.2$ & $3.4 \pm 1.5$ \\
& & & & & &
\end{tabular}

GLM results, conduit diameter class 5-10 $\mu \mathrm{m}$ : salinity*variety effect, $\mathrm{F}=2.46, \mathrm{p}=0.0904$; diameter class effect, $\mathrm{F}=4.81, \mathrm{p}=0.0306$. GLM results, conduit diameter class 10-15 $\mu \mathrm{m}$ : salinity effect, $\mathrm{F}=4.71, \mathrm{p}=0.0112$; variety effect, $\mathrm{F}=3.19, \mathrm{p}=0.0455$. GLM results, conduit diameter class $>25 \mu \mathrm{m}$; salinity effect, $\mathrm{F}=13.06, \mathrm{p}<0.0001$.

Anatomical comparisons of the moderately salt-stressed treatment $\left(4.2 \mathrm{dS} \mathrm{m}^{-1}\right)$ revealed about $10 \%$ less conduits of the smallest diameter class $(5-10 \mu \mathrm{m})$ in fine root of salt sensitive Proline trees than in those of Barnea and Arbequina (Table 3.2; GLM result, salinity*variety effect: $\mathrm{F}=2.52, \mathrm{p}=0.0857)$. Furthermore, in Barnea variety the propor- 
tion of 5-10 $\mu \mathrm{m}$ conduits increased to $78 \%$ under high salinity $\left(7.5 \mathrm{dS} \mathrm{m}^{-1}\right)$. The opposite effect was found in the $10-15 \mu \mathrm{m}$ size class: the fraction of this size class decreased in Barnea and Arbequina but increased in Proline under moderate salinity (GLM results, salinity effect: $F=4.83, p=0.0101$; variety effect: $F=3.27, p=0.0423)$.

Table 3.3 Proportion of conduit diameter classes on theoretical hydraulic conductivity $\left(\mathrm{k}_{\mathrm{h}}^{\text {theo }}\right)$ of fine roots of the Olea europea varieties Barnea, Arbequina, and Proline at different salinity treatments $\left(1.2,4.2\right.$, and $\left.7.5 \mathrm{dS} \mathrm{m}^{-1}\right)$. For Barnea fine roots under severe salt stress $\left(7.5 \mathrm{dS} \mathrm{m}^{-1}\right)$, 'normal' and high conductivity ('HC') roots were distinguished by means of outlying data (see Statistical analyses, mean \pm SE, $n=$ sample size).

Fraction conduit diameter class on theoretical hydraulic conductivity [\%]

\begin{tabular}{lccccccc}
\multicolumn{1}{c}{ Olive variety } & $\begin{array}{c}\text { Salinity } \\
{\left[\mathbf{d S} \mathbf{~ m}^{-1}\right]}\end{array}$ & $\boldsymbol{n}$ & $\mathbf{5}-\mathbf{1 0} \boldsymbol{\mu m}$ & $\mathbf{1 0}-\mathbf{1 5} \boldsymbol{\mu \mathbf { m }}$ & $\mathbf{1 5}-\mathbf{2 0} \boldsymbol{\mu m}$ & $\mathbf{2 0}-\mathbf{2 5} \boldsymbol{\mu m}$ & $>\mathbf{2 5} \boldsymbol{\mu m}$ \\
\hline & & & & & & & \\
Barnea & 1.2 & 8 & $15.3 \pm 3.9$ & $32.3 \pm 5.8$ & $28.5 \pm 4.1$ & $10.3 \pm 3.8$ & $13.7 \pm 5.9$ \\
Barnea & 4.2 & 8 & $17.5 \pm 5.0$ & $27.5 \pm 5.6$ & $28.3 \pm 3.0$ & $18.3 \pm 4.3$ & $8.5 \pm 3.8$ \\
Barnea 'normal' & 7.5 & 6 & $22.5 \pm 7.0$ & $26.2 \pm 5.8$ & $17.5 \pm 3.8$ & $10.0 \pm 2.9$ & $23.9 \pm 11.1$ \\
Barnea 'HC' & 7.5 & 4 & $0.05 \pm 0.01$ & $0.09 \pm 0.02$ & $0.12 \pm 0.03$ & $0.25 \pm 0.08$ & $99.5 \pm 0.15$ \\
Arbequina & 1.2 & 8 & $4.2 \pm 1.0$ & $13.4 \pm 1.8$ & $25.9 \pm 3.1$ & $32.5 \pm 3.2$ & $24.0 \pm 1.8$ \\
Arbequina & 4.2 & 8 & $9.8 \pm 2.4$ & $20.5 \pm 6.5$ & $24.9 \pm 6.2$ & $20.0 \pm 4.3$ & $28.8 \pm 11.6$ \\
Proline & 1.2 & 8 & $15.8 \pm 4.8$ & $28.4 \pm 7.6$ & $19.3 \pm 3.3$ & $15.0 \pm 4.7$ & $21.4 \pm 9.3$ \\
Proline & 4.2 & 8 & $9.1 \pm 2.7$ & $25.8 \pm 7.3$ & $27.6 \pm 4.5$ & $20.5 \pm 3.5$ & $16.9 \pm 7.4$ \\
\hline
\end{tabular}

In consequence of these anatomical differences, theoretical conductivity $\left(\mathrm{k}_{\mathrm{h}}{ }^{\text {theo }}\right)$ was assigned to different conduit size classes in the three varieties and salt treatments (Table 3.3). Considering the contribution of the smallest conduit size class $(\mathrm{d}=5-10 \mu \mathrm{m})$ to $\mathrm{k}_{\mathrm{h}}{ }^{\text {theo }}$, moderately salt-stressed fine-roots of Barnea cover $18 \%$ of total conductivity by means of those small conduits, while the smallest conduits contribute only about the half $(9-10 \%)$ to $\mathrm{k}_{\mathrm{h}}{ }^{\text {theo }}$ in Arbequina and Proline. The differences between moderately salt-stressed varieties become even more apparent, if conduits with diameters $<15 \mu \mathrm{m}$ are considered: fine roots of Barnea cover nearly half (45\%) of conductivity with these small diameter conduits, whereas Arbequina and Proline cover 30 and $35 \%$, respectively. Accordingly, conduits over $20 \mu \mathrm{m}$ in diameter contribute less to conductivity in fine roots of fresh water irrigated and moderately salt stressed Barnea (24-26\%) than those of both other olive varieties under the same treatments $(36-56 \%$, Table 3.3). Conductivity of highly conductive Barnea roots $\left(7.5 \mathrm{dS} \mathrm{m}^{-1}\right)$ was mainly $(99 \%)$ based on conduits with diameters $>25 \mu \mathrm{m}$ (Table 3.3). 
While the proportion of large vessels $(>25 \mu \mathrm{m})$ was significantly higher in coarse roots than in fine roots (GLM result, salinity*diameter class effect: $F=3.50, p=0.0342$ ), the same trends in conduit diameter adjustment to salinity as in fine roots were observed (Table 3.2).

\section{Specific conductivity and degree of embolism}

We found a larger variability in specific conductivity $\mathrm{k}_{\mathrm{s}}$ (axial hydraulic conductivity related to cross-sectional area) in roots than in branches (Fig. 3.3a-c). This large variability was observed in both fine roots (investigated diameters: 0.9-2.0 mm) and coarse roots $(2.0-10.0 \mathrm{~mm})$ of all three varieties. However, the variability was increased in saltstressed roots of Barnea and Arbequina. Whereas roots and shoots of some varieties und salt treatments sporadically had up to 10 -fold higher $\mathrm{k}_{\mathrm{s}}$ values than the mean of the respective samples, Barnea possesses some 'high conductivity' fine roots with 100-fold higher $\mathrm{k}_{\mathrm{s}}$ under severe salt stress (see Fig. 3.1, and crosses marking outliers in Fig. 3.3a-c). Specific conductivities of coarse roots and branches were found to be significantly higher than those of fine roots (Table 3.4).

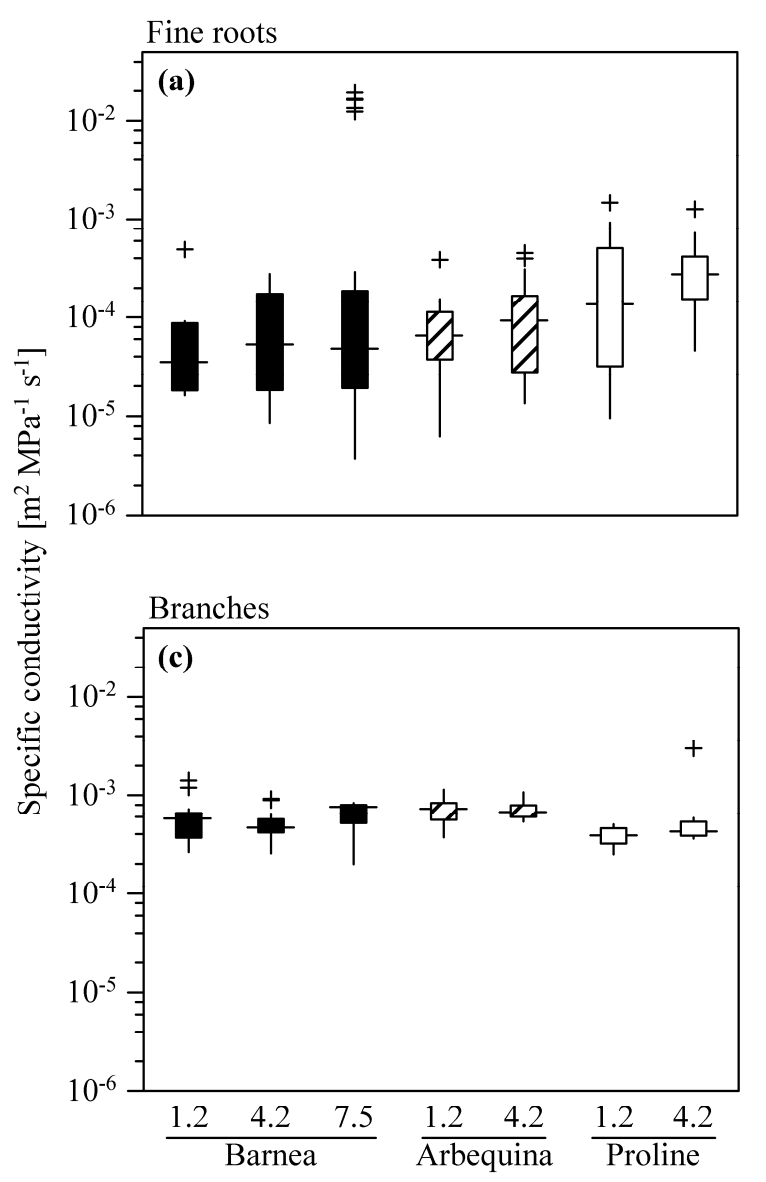

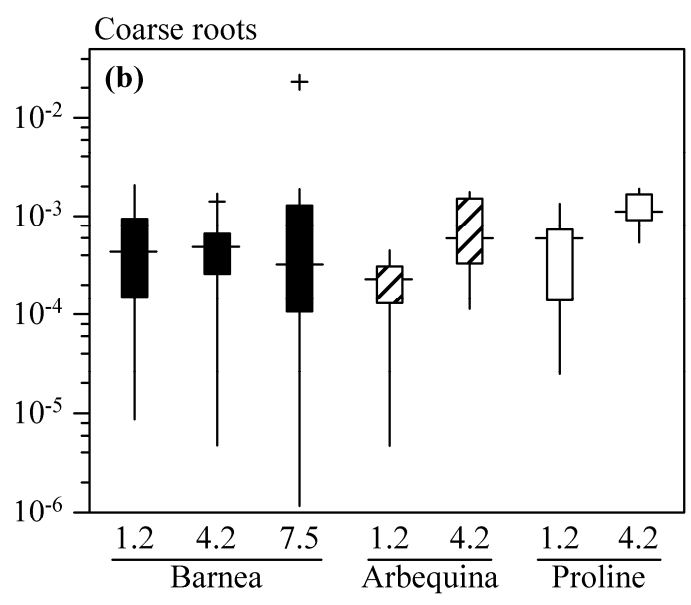

Fig. 3.3 Box plots of specific conductivities $\left(\mathrm{k}_{\mathrm{s}}, \mathrm{m}^{2} \mathrm{MPa}^{-1} \mathrm{~s}^{-1}\right)$ of fine roots (diameter $\mathrm{d} \leq 2 \mathrm{~mm})$, coarse roots $(\mathrm{d}=2-10 \mathrm{~mm})$, and branches $(\mathrm{d}=6-8 \mathrm{~mm})$ of three different salt sensitive Olea europea varieties Barnea, Arbequina, and Proline under different salinities $\left(1.2,4.2\right.$, and $\left.7.5 \mathrm{dS} \mathrm{m}^{-1}\right)$. Box plots represents the median (horizontal line), 25 and $75 \%$ percentiles (box limits), and 5 and $95 \%$ percentiles (bars). Outside values (see Statistical analyses) are plotted as + symbols. Log-transformed $(\log 10) \mathrm{y}$-axes were chosen due to presentability. See Table 3.4 for sample sizes and statistics. 
Mean specific conductivities of fine and coarse roots tended to increase with increasing salt stress (Table 3.4). However, due to the high variability in root conductivity, increases of $\mathrm{k}_{\mathrm{s}}$ due to salinity were only significant in coarse roots of Arbequina and Proline trees. Large and mostly significant differences in $\mathrm{k}_{\mathrm{s}}$ existed between fresh water irrigated fine roots of Barnea and Arbequina on the one hand, and Proline on the other, with the latter showing about 3-times higher fine root $\mathrm{k}_{\mathrm{s}}$ values. This difference in fine root $\mathrm{k}_{\mathrm{s}}$ between the more salt resistant varieties and Proline was not only found in the fresh water irrigated control but also persisted under moderately saline irrigation. No significant differences were found between branches of the fresh water irrigated and salt-stressed treatments (Fig. 3.3c, Table 3.4).

Table 3.4 Mean specific conductivity $\left(\mathrm{k}_{\mathrm{s}}, \mathrm{m}^{2} \mathrm{MPa}^{-1} \mathrm{~s}^{-1}\right)$ and degree of embolism (\%) in fine roots, coarse roots, and branches of the Olea europea varieties Barnea, Arbequina, and Proline under different salinities $\left(1.2,4.2\right.$, and $\left.7.5 \mathrm{dS} \mathrm{m}^{-1}\right)$. Significant differences between salinity treatments within fine roots, coarse roots, and branches are indicated by different lower case letters, and significant differences between fine roots, coarse roots, and branches of the same variety and salinity treatment by different capital letters (Mann-Whitney U test, $\mathrm{p}<0.05$, mean $\pm \mathrm{SE}, n=$ sample size).

\begin{tabular}{|c|c|c|c|c|c|c|}
\hline \multirow{2}{*}{$\begin{array}{l}\text { Olive variety } \\
\text { Fine roots }\end{array}$} & \multirow[t]{2}{*}{$\begin{array}{l}\text { Salinity } \\
{\left[\mathrm{dS} \mathrm{m}^{-1}\right]}\end{array}$} & \multirow[t]{2}{*}{$n$} & \multicolumn{2}{|c|}{$\left[10^{-4} \mathrm{~m}^{2} \mathrm{~s}_{\mathrm{s}}^{-1} \mathrm{MPa}^{-1}\right]$} & \multicolumn{2}{|c|}{ Embolism [\%] } \\
\hline & & & & & & \\
\hline Barnea & 1.2 & 14 & $0.9 \pm 0.4$ & $\mathrm{aA}$ & $24.8 \pm 8.1$ & $\mathrm{abcA}$ \\
\hline Barnea & 4.2 & 11 & $1.0 \pm 0.3$ & $\mathrm{abA}$ & $21.2 \pm 11.2$ & $\mathrm{aA}$ \\
\hline Barnea & 7.5 & 26 & $30.6 \pm 12.5$ & $\mathrm{abA}$ & $22.8 \pm 5.2$ & $\mathrm{abA}$ \\
\hline Arbequina & 1.2 & 18 & $1.0 \pm 0.3$ & $\mathrm{abA}$ & $18.2 \pm 4.7$ & $a b A$ \\
\hline Arbequina & 4.2 & 16 & $1.3 \pm 0.3$ & $\mathrm{abA}$ & $33.0 \pm 7.6$ & bdA \\
\hline Proline & 1.2 & 20 & $3.0 \pm 0.9$ & bcA & $36.3 \pm 6.2$ & $\operatorname{cdA}$ \\
\hline Proline & 4.2 & 22 & $3.7 \pm 0.7$ & $\mathrm{cA}$ & $22.3 \pm 4.8$ & $a b c A$ \\
\hline \multicolumn{7}{|l|}{ Coarse roots } \\
\hline Barnea & 1.2 & 30 & $6.2 \pm 1.1$ & $a b B$ & $39.5 \pm 4.6$ & $\mathrm{aB}$ \\
\hline Barnea & 4.2 & 33 & $4.9 \pm 0.6$ & $\mathrm{aB}$ & $26.6 \pm 3.1$ & $\mathrm{bB}$ \\
\hline Barnea & 7.5 & 23 & $15.4 \pm 9.9$ & $\mathrm{abB}$ & $35.2 \pm 6.8$ & $\mathrm{abA}$ \\
\hline Arbequina & 1.2 & 11 & $2.2 \pm 0.4$ & $\mathrm{bB}$ & $12.3 \pm 4.1$ & $\operatorname{cdeA}$ \\
\hline Arbequina & 4.2 & 8 & $8.4 \pm 2.3$ & $\mathrm{acB}$ & $23.0 \pm 11.5$ & bdA \\
\hline Proline & 1.2 & 22 & $5.2 \pm 0.8$ & $\mathrm{aB}$ & $33.1 \pm 5.4$ & $a b A$ \\
\hline Proline & 4.2 & 14 & $12.2 \pm 1.1$ & $\mathrm{cB}$ & $25.9 \pm 6.8$ & beAB \\
\hline \multicolumn{7}{|l|}{ Branches } \\
\hline Barnea & 1.2 & 11 & $6.2 \pm 1.1$ & $a b c B$ & $10.5 \pm 2.1$ & $\mathrm{abA}$ \\
\hline Barnea & 4.2 & 11 & $5.2 \pm 0.5$ & $\mathrm{acB}$ & $11.2 \pm 2.2$ & $\mathrm{aA}$ \\
\hline Barnea & 7.5 & 11 & $6.4 \pm 0.7$ & $\mathrm{adB}$ & $18.7 \pm 3.7$ & bdA \\
\hline Arbequina & 1.2 & 11 & $7.1 \pm 0.7$ & bdC & $32.8 \pm 3.7$ & $\mathrm{cB}$ \\
\hline Arbequina & 4.2 & 11 & $7.1 \pm 0.5$ & $\mathrm{bdB}$ & $26.3 \pm 3.8$ & $\operatorname{cdA}$ \\
\hline Proline & 1.2 & 11 & $3.8 \pm 0.3$ & ceAB & $29.5 \pm 4.9$ & $\mathrm{cA}$ \\
\hline Proline & 4.2 & 11 & $6.8 \pm 2.3$ & $\mathrm{aeC}$ & $35.5 \pm 6.8$ & $\mathrm{cB}$ \\
\hline
\end{tabular}


The degree of embolism in fine roots, coarse roots and branches was not significantly higher in roots and branches of salt-stressed trees of the three olive varieties than in fresh water-irrigated ones (Table 3.4). Changes of coarse root embolism rates of all three olive varieties were in accordance with changes in degree of fine root embolism, and no significant differences were found between organs. However, the degree of embolism in branches of Arbequina and Proline was significantly higher than in branches of Barnea (Table 3.4).

\subsection{DISCUSSION}

\section{Adjustment of root xylem anatomy to salt stress}

Trees are known to respond to drought and salt stress with modifications in their wood anatomy such as changes in xylem density and conduit diameters (Kozlowski 1997). In previous studies, the xylem in salt stressed stems and roots has been found to contain vessels with smaller diameters (Valenti et al. 1991, Reinhardt and Rost 1995, Junghans et al. 2006) and higher vessel densities (Millner 1934, Solomon et al. 1986, Sobrado 2007). Both high vessel density and decreasing vessel dimensions are associated with an increased hydraulic safety (Lo Gullo et al. 1995, Eshel et al. 2000).

In this study, mean conduit diameters, hydraulically weighted conduit diameter and maximum vessel diameters in roots of the three olive varieties were mostly unaltered or only slightly decreased under moderate salt stress and even increased in high conductivity roots of Barnea under severe salt stress (Fig. 3.2a,c, Table 3.2). This discrepancy to previous studies might be a consequence of already remarkably small root conduits of olive under fresh water irrigation, compared to other Mediterranean species (Table 3.2; Martínez-Vilalta et al. 2002).

However, small mean conduit diameters may be a common adaptation to an increased tension of the water column in the conducting system (Baas et al. 1983, Stevenson and Mauseth 2001), and may explain the general drought and salinity tolerance of Olea europaea, but they cannot explain the differences in salt resistance between the three studied olive varieties.

Recently, the results of Schmitz et al. (2006) questioned the relevance of smaller mean conduit diameters for increasing hydraulic safety in favour of vessel density, which is 
obviously interrelated to the fraction of small diameter conduits. Our results show an increased formation of smallest diameter conduits $(d=5-10 \mu \mathrm{m})$ in salt-stressed fine roots of Barnea (highly tolerant) and Arbequina (tolerant) trees. In contrast, saltsensitive Proline trees had a 10\% smaller proportion of narrow conduits under moderate salinity and even 20\% less narrow conduits than severely salt-stressed Barnea (Table 3.2). While $18 \%$ of the absorbed water was conducted in those smallest vessels in fine roots of moderately stressed Barnea, only half of that $(9 \%)$ was transported in those small vessels in Proline (Table 3.3).

This is supposed to have major effects on the appearance and impact of embolism. Even though conduit diameters were thought to be rarely directly coupled to cavitation vulnerability (Hacke and Sperry 2001), narrow conduits may be advantageous with respect to embolism: they are typically associated with smaller pit membrane pores (MartínezVilalta et al. 2002), relatively larger wall strength (Hacke et al. 2001) and refill easier after embolism (Grace 1993, Holbrook and Zwieniecki 1999). In any case, a conduit population with an increased total number should improve its relative degree of safety since the impact of cavitation in single conduits on total loss of conductivity is lower (Mauseth and Stevenson 2004). Nevertheless, fine roots of Barnea under severe salt stress realised larger proportions of their conductivity with vessels $>20 \mu \mathrm{m}$ in diameter, combining both safety and considerable conductivity in a more dimorphic conduit distribution pattern when severely stressed. The increased water use efficiency of a vascular system with both very small (safe) and large conduits (efficient) may account for its frequent occurrence in the flora of arid regions (Baas et al. 1983).

In addition, significantly larger conduit diameters were observed in specialized high conductivity roots of Barnea trees after exposure to severe salt stress (Figs. 3.1b, 3.2a,b). Different parts of a root system have been found to respond independently to salt stress (Waisel and Breckle 1987). While differentiation within the vessel population as discussed earlier may be a favourable adaptation to temporal changes in soil salinity, we suggest that the differentiation in 'high conductivity' and 'normal' roots (Fig. 3.1) poses an effective adaptation to soils varying spatially in salinity, such as drip-irrigated orchards (Mmolawa and Or 2000, Isla et al. 2003). Shani et al. (1993) have found a comparable 'specialization' in root hydraulics due to salinity, where most of the water uptake occurred by means of fresh water-accessing roots. 


\section{Does salinity affect conductivity in situ?}

The specific conductivities $\left(\mathrm{k}_{\mathrm{s}}\right)$ in roots and shoots of olive in this study were lower than $\mathrm{k}_{\mathrm{s}}$ measured in other woody Mediterranean species (Martínez-Vilalta et al. 2002) but in accordance with $\mathrm{k}_{\mathrm{s}}$ values found in olive coarse roots, recently published by Nardini et al. (2006). No significant differences in $\mathrm{k}_{\mathrm{s}}$ were found between branches of fresh water and saline water irrigated trees (Fig. 3.3c, Table 3.4). This may indicate a lower sensitivity of the above-ground hydraulic system to salt stress in comparison with the significantly altered $\mathrm{k}_{\mathrm{s}}$ in coarse roots of Arbequina and Proline.

No agreement has been revealed yet as to whether reduced (Shannon et al. 1994) or increased root conductivities (An et al. 2003) pose an adaptation to saline soils. Our results indicate that the more salt-resistant Barnea and Arbequina varieties possess lower axial conductivities in fine roots than salt-sensitive Proline trees, which is supporting the first assumption.

However, root conductivity increased with increasing salt stress, which contrasts previous result (Munns and Passioura 1984, Navarro et al. 2007). However, those studies were measuring total root conductivity, thereby including both radial and axial conductivity. Root radial conductivity is thought to be orders of magnitude smaller than axial conductivity (Frensch and Steudle 1989). Nevertheless, axial resistance can be a significant component of total resistance (Passioura 1972), especially in woody plants under water shortage (Hacke et al. 2000). The path length of radial water flow is much less than axial length, indicating the importance of axial conductivity especially in large woody plants (Addington et al. 2006).

Thus, increased axial conductivities are suggested to balance an increase of radial resistance by reducing resistance in another part of the root hydraulic system, or may have a 'compensatory effect' (West 1978) with regard to decreasing root biomasses or root numbers under salinity, as reported for several woody species (e.g. Krauss et al. 1999) and Olea europea var. Barnea in the same plot (Weissbein 2006). The importance of compensating increased resistances in small-sized root systems is underlined by a positive correlation between root hydraulic conductance and leaf surface area in olive (Nardini et al. 2006) and the reduced water uptake in salt stressed olive trees, resulting in limitation of photosynthesis (Loreto et al. 2003).

Considering the spreading of $\mathrm{k}_{\mathrm{s}}$ in roots with increasing salinity (Fig. 3.3a,b), it is obvious that $\mathrm{k}_{\mathrm{s}}$ of the bulk of Proline roots increased, whereas Barnea and Arbequina pos- 
sess individual roots with increased and others with decreased conductivities under salt stress. The differentiation in more and less conductive roots in Barnea variety (Fig. 3.3a,b) is in accordance with detected anatomical adaptations of the xylem under severe salt stress (Table 3.3). It is suggested to be most favourable in environments with spatiotemporal heterogeneous water availabilities (see earlier in text). The amplitude of functional adaptations in response to heterogeneous environmental signals may indicate a different genetic potential of the three olive varieties, and the superiority of Arbequina and especially Barnea with regard to salt resistance. Although, those adaptations did not result in lower degrees of embolism in fine and coarse roots of Barnea and Arbequina trees than in Proline, branches of Barnea exhibited significantly lower embolism rates. This may underline the effectiveness of a dimorphic root system in preventing embolism in the shoot.

\subsection{CONCLUSION}

In previous studies, it has been demonstrated that differences in growth reduction caused by salt stress are the result of differences in root system structure (Lin and Sternberg 1994) or salt exclusion capacities (Mickelbart and Arpaia 2002). Shani et al. (1993) pointed to the importance of functionally differentiated root systems for water acquisition in heterogeneously saline soils. Our study underlined the importance of morphological adjustments and functional differentiation within the root hydraulic system. The highly salt tolerant olive variety Barnea showed major plastic adaptations at two levels of organisation: at a vascular level within an individual root (conduit size distribution) and between roots at the level of organ (diversification of roots with contrasting conductivities and 'high conductivity' roots). We conclude that high plasticity of the root hydraulic system in this variety of olive is an effective mechanism in adaption to salinity. 


\subsection{REFERENCES}

Addington RN, Donovan LA, Mitchell RJ, Vose JM, Pecot SD, Jack SB, Hacke UG, Sperry JS, Oren R. 2006. Adjustments in hydraulic architecture of Pinus palustris maintain similar stomatal conductance in xeric and mesic habitats. Plant, Cell and Environment 29: 535-545.

An P, Inanaga S, Xiangjun L, Shimizu H, Tanimoto E. 2003. Root characteristics in salt tolerance. Root Research 12: 125-132.

Aragüés R, Puy J, Royo A, Espada JL. 2005. Three-year field response of young olive trees (Olea europaea L. cv. Arbequina) to soil salinity: Trunk growth and leaf ion accumulation. Plant and Soil 271: $265-273$

Azaizeh H, Steudle E. 1991. Effects of salinity on water transport of excised maize (Zea mays L.) roots. Plant Physiology 97: 1136-1145.

Baas P, Werker E, Fahn A. 1983. Some ecological trends in vessel characters. IAWA Bulletin 4: 141-159.

Beltran JM. 1999. Irrigation with saline water: benefits and environmental impact. Agricultural Water Management 40: 183-194.

Bernstein L, Hayward HE. 1958. Physiology of salt tolerance. Annual Review of Plant Physiology and Plant Molecular Biology 9: 25-46.

Carter JL, Colmer TD, Veneklaas EJ. 2006. Variable tolerance of wetland tree species to combined salinity and waterlogging is related to regulation of ion uptake and production of organic solutes. New Phytologist 169: 123-133.

Chartzoulakis K, Michelakis N, Tsompanakis I. 1992. The effects of water amount and application date on yield and water utilization efficiency of Koroneiki olives under drip irrigation. Advances in Horticultural Science 6: 82-84.

Core HA, Côté WA, Day AC. 1979. Wood structure and identification. Syracuse, USA: University Press.

Dajic Z. 2006. Salt stress. In: Rao KVM, Raghavendra AS, Reddy KJ, eds. Physiology and molecular biology of stress tolerance in plants. Berlin, Germany: Springer, 41-99.

Demiral MA. 2005. Comparative response of two olive (Olea europea L.) cultivars to salinity. Turk Journal of Agricultural Forestry 29: 267-274.

Eshel A, Shick I, Waisel Y. 2000. The efficiency of the water conducting system in tomato roots - Hydraulic conductivity of tomato roots. In: Stokes A, ed. The supporting roots of trees and woody plants: Form, function and physiology. Dordrecht, The Netherlands: Kluwer, 371-375.

Fahn A, Werker E, Baas P. 1986. Woody anatomy and identification of trees and shrubs from Israel and adjacent regions. Jerusalem, Israel: Academy of Sciences and Humanities.

FAO 1985. Water quality for agriculture. Rome, Italy: FAO.

Flowers TJ, Flowers SA. 2005. Why does salinity pose such a difficult problem for plant breeders? Agricultural Water Management 78: 15-24.

Frensch J, Steudle E. 1989. Axial and radial hydraulic resistance to roots of maize (Zea mays L.). Plant Physiology 91: 719-726.

Grace J. 1993. Refilling of embolized xylem. In: Borghetti M, Grace J, Raschi A, eds. Water transport in plants under climatic stress. Cambridge, UK: University Press, 51-62.

Gucci R, Lombardini L, Tattini M. 1997. Analysis of leaf water relations in leaves of two olive (Olea europaea) cultivars differing in tolerance to salinity. Tree Physiology 17: 13-21.

Hacke UG, Sperry J, Pittermann J. 2000. Drought experience and cavitation resistance in six shrubs from the Great Basin, Utah. Basic and Applied Ecology 1: 31-41.

Hacke UG, Sperry JS. 2001. Functional and ecological xylem anatomy. Perspectives in Plant Ecology, Evolution and Systematics 4: 97-115. 
Hacke UG, Sperry JS, Pockman WT, Davis SD, McCulloch KA. 2001. Trends in wood density and structure are linked to prevention of xylem implosion by negative pressure. Oecologia 126: 457-461.

Holbrook NM, Zwieniecki MA. 1999. Embolism repair and xylem tension: Do we need a miracle? Plant Physiology 120: 7-10.

Huber B. 1956. Die Gefäßleitung. In: Ruhland W, ed. Handbuch der Pflanzenphysiologie, vol. 2. Berlin, Germany: Springer, 541-582.

Isla R, Aragüés R, Royo A. 2003. Spatial variability of salt-affected soils in the middle Ebro Valley (Spain) and implications in plant breeding for increased productivity. Euphytica 134: 325-334.

Junghans U, Polle A, Duchting P, Weiler E, Kuhlman B, Gruber F, Teichmann T. 2006. Adaptation to high salinity in poplar involves changes in xylem anatomy and auxin physiology. Plant, Cell and Environment 29: 1519-1531.

Kocacinar F, Sage RF. 2004. Photosynthetic pathway alters hydraulic structure and function in woody plants. Oecologia 139: 214-223.

Kozlowski TT. 1997. Responses of woody plants to flooding and salinity. Tree Physiology Monograph 1: 1-29.

Krauss KW, Chambers JL, Allen JA, Luse BP, DeBosier AS. 1999. Root and shoot responses of Taxodium distichum seedlings subjected to saline flooding. Environmental and Experimental Botany 41: $15-23$.

Lacan D, Durand M. 1995. $\mathrm{Na}^{+}$and $\mathrm{K}^{+}$Transport in excised soybean roots. Physiologia Plantarum 93: 132-138.

Lewis AM, Boose ER. 1995. Estimating volume flow-rates through xylem conduits. American Journal of Botany 82: 1112-1116.

Lin GH, Sternberg LSL. 1994. Utilization of surface water by red mangrove (Rhizophora mangele L.): An isotopic study. Bulletin of Marine Science 54: 94-102.

Lo Gullo MA, Salleo S, Piaceri EC, Rosso R. 1995. Relations between vulnerability to xylem embolism and xylem conduit dimensions in young trees of Quercus cerris. Plant, Cell and Environment 18: 661-669.

Loreto F, Centritto M, Chartzoulakis K. 2003. Photosynthetic limitations in olive cultivars with different sensitivity to salt stress. Plant, Cell and Environment 26: 595-601.

Martínez-Vilalta J, Prat E, Oliveras I, Piñol J. 2002. Xylem hydraulic properties of roots and stems of nine Mediterranean woody species. Oecologia 133: 19-29.

Mauseth JD, Stevenson JF. 2004. Theoretical considerations of vessel diameter and conductive safety in populations of vessels. International Journal of Plant Sciences 165: 359-368.

Mickelbart MV, Arpaia ML. 2002. Rootstock influences changes in ion concentrations, growth, and photosynthesis of 'Hass' avocado trees in response to salinity. Journal of the American Society for Horticultural Science 127: 649-655.

Millner ME. 1934. Anatomy of Silene vulgaris and S. maritima as related to ecological and genetical problems. I. Root Structure. New Phytologist 32: 77-95.

Mmolawa K, Or D. 2000. Root zone solute dynamics under drip irrigation: A review. Plant and Soil 222: 163-190.

Munns R, Passioura JB. 1984. Hydraulic resistance of plants. 3. Effects of $\mathrm{NaCl}$ in barley and lupin. Australian Journal of Plant Physiology 11: 351-359.

Nardini A, Gascò A, Raimondo F, Gortan E, Lo Gullo MA, Caruso T, Salleo S. 2006. Is rootstockinduced dwarfing in olive an effect of reduced plant hydraulic efficiency? Tree Physiology 26: 1137-1144.

Navarro A, Bañon S, Olmos E, Sanchez-Blanco MJ. 2007. Effects of sodium chloride on water potential components, hydraulic conductivity, gas exchange and leaf ultrastructure of Arbutus unedo plants. Plant Science 172: 473-480.

Oron G, DeMalach Y, Gillerman L, David I, Rao VP. 1999. Improved saline-water use under subsurface drip irrigation. Agricultural Water Management 39: 19-33. 
Passioura JB. 1972. The effect of root geometry on yield of wheat growing on stored water. Australian Journal of Agricultural Research 23: 745-752.

Reinhardt DH, Rost TL. 1995. Developmental changes of cotton root primary tissues induced by salinity. International Journal of Plant Sciences 156: 505-513.

Salleo S, Nardini A, Pitt F, Lo Gullo MA. 2000. Xylem cavitation and hydraulic control of stomatal conductance in laurel (Laurus nobilis L.). Plant, Cell and Environment 23: 71-79.

Schmitz N, Verheyden A, Beeckman H, Kairo JG, Koedam N. 2006. Influence of a salinity gradient on the vessel characters of the mangrove species Rhizophora mucronata. Annals of Botany 98: $1321-1330$.

Shani U, Waisel Y, Eshel A, Xue S, Ziv G. 1993. Responses to salinity of grapevine plants with split root systems. New Phytologist 124: 695-701.

Shannon MC, Grieve CM, Francoise LE. 1994. Whole-plant response to salinity. In: Wilkinson RE, ed. Plant environment interactions. New York, USA: Dekker, 199-244.

Shannon MC. 1997. Adaptation of plants to salinity. Advances in Agronomy 60: 75-120.

Sobrado MA. 2007. Relationship of water transport to anatomical features in the mangrove Laguncularia racemosa grown under contrasting salinities. New Phytologist 173: 584-591.

Solomon M, Gedalovich E, Mayer A, Poljakoff-Mayber A. 1986. Changes induced by salinity to the anatomy and morphology of excised pea roots in culture. Annals of Botany 57: 811-818.

Sperry JS, Donnelly JR, Tyree MT. 1988. A method for measuring hydraulic conductivity and embolism in xylem. Plant, Cell and Environment 11:35-40.

Stevenson JF, Mauseth JD. 2004. Effects of environment on vessel characters in cactus wood. International Journal of Plant Sciences 165: 347-357.

Tabatabaei SJ. 2006. Effects of salinity and $\mathrm{N}$ on the growth, photosynthesis and $\mathrm{N}$ status of olive (Olea europaea L.) trees. Scientia Horticulturae 108: 432-438.

Tattini M, Remorini D, Pinelli P, Agati G, Saracini E, Traversi ML, Massai R. 2006. Morpho-anatomical, physiological and biochemical adjustments in response to root zone salinity stress and high solar radiation in two Mediterranean evergreen shrubs, Myrtus communis and Pistacia lentiscus. New Phytologist 170: 779-794.

Tyree MT. 2003. Hydraulic limits on tree performance: transpiration, carbon gain and growth of trees. Trees - Structure and Function 17: 95-100.

Tyree MT, Engelbrecht BMJ, Vargas G, Kursar TA. 2003. Desiccation tolerance of five tropical seedlings in Panama. Relationship to a field assessment of drought performance. Plant Physiology 132: $1439-1447$.

Valenti GS, Ferro M, Ferraro D, Riveros F. 1991. Anatomical changes in Prosopis tamarugo PHIL. seedlings growing at different levels of $\mathrm{NaCl}$ salinity. Annals of Botany 68: 47-53.

Velleman PF, Hoaglin DC. 1981. The ABCs of EDA: Applications, basics, and computing of exploratory data analysis. Boston, USA: Duxbury Press.

Waisel Y. 1972. Biology of halophytes. New York, USA: Academic Press.

Waisel Y, Breckle W. 1987. Differences in responses of various Radish roots to salinity. Plant and Soil 104: 191-194.

Weissbein S. 2006. Characterization of new olive (Olea europea L.) varieties response to irrigation with saline water in the Ramat Negev area. Master thesis. Ben-Gurion University of the Negev, Israel.

West DW. 1978. Water use and sodium-chloride uptake by apple trees. 2. The response to soil oxygen deficiency. Plant and Soil 50: 51-65.

Wiesman Z, Itzhak D, Ben Dom N. 2004. Optimization of saline water level for sustainable Barnea olive and oil production in desert conditions. Scientia Horticulturae 100: 257-266. 
Chapter 4

\section{BELOWGROUND COMPETITION IN A BROAD-LEAVED TEMPERATE MIXED FOREST - PATTERN ANALYSIS AND EXPERIMENTS IN A FOUR-SPECIES STAND}

Boris Rewald and Christoph Leuschner 


\subsection{ABSTRACT}

We investigated fine root biomass and distribution patterns in a species-rich temperate Carpinus-Quercus-Fagus-Tilia forest and searched for experimental evidence of symmetry or asymmetry in belowground competition. We conducted extensive root coring and applied the recently introduced in situ-root growth chamber technique for quantifying fine root growth under experimentally altered intra- and interspecific root neighbourhoods in the intact stand.

In $75 \%$ of all soil cores, fine roots of more than two tree species were present indicating a broad overlap of the root systems of neighbouring trees. Quercus trees had more than 10 times less fine root biomass in relation to aboveground biomass or productivity (stem growth) and a much higher leaf area index/root area index ratio than Carpinus, Fagus and Tilia trees. The root growth chamber experiments indicated a high belowground competitive ability of Fagus in interspecific interactions, but a low one of Quercus.

We conclude that (i) interspecific root competition is ubiquitous in this mixed stand, (ii) root competition between trees can be clearly asymmetric, and (iii) tree species may be ranked according to their belowground competitive ability. Fagus was found to be the most successful species in belowground competition, which matches with its superiority in aboveground competition in this forest community. 


\subsection{INTRODUCTION}

A bulk of experimental and observational studies have provided convincing evidence that root competition is an important structuring force in many, if not most, terrestrial plant communities (Wilson 1988, Coomes and Grubb 2000). Current research focuses on the importance of root competition relative to other factors in determining growth and survival of plants and in affecting the diversity and species composition of plant communities (Rajaniemi et al. 2003, Ludwig et al. 2004). Because the mode of competition substantially influences population and community dynamics (Komnicki 1980, Yokozawa et al. 1998, Aikio and Pakkasmaa 2003), there is a vital debate as to whether belowground competition is symmetric or asymmetric (de Kroon et al. 2003, Schenk 2006). Most experimental evidence suggests that soil resource acquisition by root systems of competing plants tends to be proportional to their sizes ('symmetric'; Weiner et al. 1997, Cahill and Casper 2000). In contrast to light competition, larger root systems per se cannot simply preempt nutrients or water at the expense of smaller plants. However, most of these results were obtained under artificial, homogeneous soil conditions (Hutchings and John 2004). It has been suggested that the picture of symmetric competition belowground may not be valid in patchy natural environments (Jackson and Caldwell 1993), where larger and faster growing root systems could exploit resources more completely (Campbell et al. 1991, Van Lear and Kapeluck 1995, Schwinning and Weiner 1998). Thus, the outcome of belowground competition in mixed stands may largely depend on the rate and degree as to which different species can access temporal or spatial resource patches in the soil (Thomas and Weiner 1989). In any case, experimental evidence for asymmetric belowground competition is still scarce (Blair 2001, Rajaniemi 2003, von Wettberg and Weiner 2003).

A second topic able to change our perception of belowground competition is the search for organic compounds released in root-root and root-soil interactions (Bais et al. 2003, Bonanomi et al. 2005, Falik et al. 2003). Chemical signals, yet unknown recognition systems in roots, and indirect root interactions involving other soil organisms may play an important role in the belowground interaction between tree root systems (Schenk 2006). Competition between roots of the same individual will lower resource use efficiency and possibly may reduce plant fitness (Schenk 2006). Indeed, roots have been found to avoid competition with roots of the same plant (Holzapfel and Alpert 2003, 
Gruntman and Novoplansky 2004, Falik et al. 2005). On the other hand, a plant may increase its fitness by growing roots into soil shared with a competitor, allowing it to acquire resources from that space and also to decrease the competitors' fitness by reducing its resource supply (Robinson et al. 1999).

Various studies found a certain degree of niche partitioning in terms of rooting depth and placing of roots, root dynamics and resource acquisition strategies in mixed stands of herbs and grasses (Parrish and Bazzaz 1976, Mamolos et al. 1995, Nobel 1997, Fargione and Tilman 2005). Belowground interactions among woody plants have mostly been studied in agroforestry systems (Nambiar and Sands 1993). In forests, manipulative studies have mainly focused on root competition between adult trees and forest herbs or tree seedlings (Coomes and Grubb 2000, Barberis and Tanner 2005). Therefore, the significance of root competition between mature trees in intact stands, and the importance of root competition for tree growth, vitality and species coexistence in mixed forests is poorly understood. This is mainly a consequence of difficult access to the root system of trees and the lack of adequate techniques for studying root competition between trees experimentally.

Here, we present the results of a combined observational and experimental study in a Carpinus-Quercus-Fagus-Tilia temperate mixed forest, which investigated the abundance and horizontal distribution and the relative growth rate of fine roots in different competitive neighbourhoods.

Study aims were (i) to relate aboveground structure (leaf area index, stem density, basal area, stem growth) to belowground structure (fine root biomass and root area index) in the four coexisting tree species, (ii) to quantify the extent of root system overlap, (iii) to assess the evidence for symmetry or asymmetry in fine root competition, and (iv) to attempt a ranking of the four species with respect to belowground competitive ability in this mixed stand. We tested the hypotheses that (1) trees with a large aboveground biomass have a roughly proportional biomass belowground, (2) tree root systems are spatially segregated, i.e. territorial in the sense of Schenk et al. (1999), and (3) belowground competition is symmetric in forests. 


\subsection{METHODS}

Study site

The study was carried out in 2002 in a four-species mixed forest consisting of 120 - to 130-yr-old Fagus sylvatica L. (European beech) and Quercus petraea (MATT.) LIEBL. (Sessile oak) trees, and of 70- to 90-yr-old Tilia cordata MiLl. (linden) and Carpinus betulus L. (hornbeam) trees in the Ziegelrodaer Forst south of the city of Eisleben in Saxony-Anhalt, Central Germany $\left(51^{\circ} 25^{\prime} \mathrm{N}, 11^{\circ} 31^{\prime} \mathrm{E}\right)$. Forty-seven percent of the tree individuals (diameter at breast height: $\mathrm{DBH} \geq 7 \mathrm{~cm}$ ) belonged to Carpinus, $40 \%$ to Quercus, $10 \%$ to Fagus and 3\% to Tilia (Table 4.1).

Table 4.1 Stand structural characteristics of the Carpinus, Fagus, Quercus and Tilia trees (DBH $\geq 7 \mathrm{~cm})$ in the 0.37 ha study plot. Significant differences between the species are indicated by different letters $($ mean \pm SE, DBH and leaf area index: U-test after Mann and Whitney, tree height: Scheffé test, $\mathrm{P}<0.05)$.

\begin{tabular}{|c|c|c|c|c|c|c|}
\hline & $\begin{array}{l}\text { Stem density } \\
\quad\left[\mathrm{n} \mathrm{ha}^{-1}\right]\end{array}$ & $\begin{array}{c}\text { Mean DBH } \\
{[\mathrm{cm}]}\end{array}$ & & $\begin{array}{l}\text { Mean tree } \\
\text { height [m] }\end{array}$ & $\begin{array}{c}\text { Stem basal } \\
\text { area } \\
{\left[\mathrm{m}^{2} \mathbf{h a}^{-1}\right]}\end{array}$ & $\begin{array}{c}\text { Leaf area } \\
\text { index } \\
{\left[\mathrm{m}^{2} \mathbf{m}^{-2}\right]}\end{array}$ \\
\hline Carpinus & 166 & $23.0 \pm 0.9$ & $\mathrm{a}$ & $19.0 \pm 0.6$ & 8.6 & $1.7 \pm 0.1 \mathrm{a}$ \\
\hline Fagus & 36 & $46.2 \pm 2.5$ & $b$ & $30.1 \pm 0.8$ & 6.6 & $2.3 \pm 0.1 \mathrm{~b}$ \\
\hline Quercus & 140 & $39.7 \pm 0.8$ & $\mathrm{~b}$ & $27.9 \pm 0.2 \quad b$ & 18.3 & $3.3 \pm 0.1 \mathrm{c}$ \\
\hline Tilia & 10 & $39.0 \pm 2.9$ & $\mathrm{ab}$ & $26.1 \pm 1.1 \mathrm{ab}$ & 1.3 & $0.5 \pm 0.1 \mathrm{~d}$ \\
\hline Stand total & 352 & - & & - & 34.8 & $7.8 \pm 0.2$ \\
\hline
\end{tabular}

Located in the transition zone between the sub-oceanic and sub-continental regions of Central Europe, the stand represents a community, which is intermediate between a beech forest on eutrophic Cambisol (Galio-Fagetum community after Ellenberg 1996) and an oak-hornbeam-linden forest (Tilio-Carpinetum). The forest has been managed with the prime goal to produce Quercus logs in the past centuries. A substantial reduction in management intensity in the last three decades favoured the regrowth of Carpinus, which now forms a second tree layer under the upper canopy of Quercus and Fagus trees. Total stem density was $352 \mathrm{ha}^{-1}$ (all stems with $\mathrm{DBH} \geq 7 \mathrm{~cm}$ ) with Carpinus contributing most of the thinner stems. Fagus, Quercus and Tilia did not differ significantly with respect to $\mathrm{DBH}(39-46 \mathrm{~cm})$ and mean tree height $(26-30 \mathrm{~m})$, whereas the Carpinus trees were, on average, less tall and had a lower DBH (Table 4.1). 
While a shrub layer was nearly absent $(<2 \%$ cover), about $10 \%$ of the forest floor was occupied by forest herbs (Anemone nemorosa L., Stellaria holostea L., Athyrium filixfemina (L.) RotH and other species).

Mean annual precipitation was $462 \mathrm{~mm}$ at the nearby weather station of Allstedt; it is assumed that the study plot at a somewhat higher elevation received about $520 \mathrm{~mm} \mathrm{yr}^{-1}$ with approximately $55 \%$ of the annual precipitation falling from May to September (300 mm in the study year 2002). The mean annual temperature was $8.6{ }^{\circ} \mathrm{C}$. The soils were meso- to eutrophic Cambisols $\left(\mathrm{pH}\left(\mathrm{H}_{2} \mathrm{O}\right)\right.$ : 4.3-4.4, base saturation about $40 \%$ in the topsoil) derived from Triassic sandstone (Upper Bunter) covered by a thin layer of Pleistocene eolic loess deposits. Atop of the mineral soil, a thin $(5-30 \mathrm{~mm})$ layer of ectorganic material (humus form: mull) was present. The groundwater horizon was far below the rooting zone.

Selection criteria for the study plot were (i) absence of canopy gaps, (ii) a representative tree species composition with respect to the forest community, and (iii) only minor soil disturbance by wild boar. A plot of 0.37 ha $(45 \times 92 \mathrm{~m})$, which fulfilled these criteria, was selected and fenced, and all stems $\geq 7 \mathrm{~cm}$ DBH were mapped. Diameter at breast height was measured with dendrometer tapes at $1.3 \mathrm{~m}$ height, tree height with an ultrasonic Vertex III height meter (Haglöf, Sweden). For monitoring stem increment, 4 to 12 stems per species were instrumented with dendrometer tapes and read seven times during a period of 12 months. The stems used for increment measurement were selected in direct proximity to the root coring transects (see below); the stems represented the most abundant diameter classes of the species in the stand. We used allometric regressions based on $\mathrm{DBH}$ and stem form to estimate annual stem growth of the four species using the single-tree modelling software BWinPro (Nagel and Schmidt 2006). The leaf area index (LAI) was measured by litter sampling in autumn. Litter fall was collected with 30 litter buckets of $0.29 \mathrm{~m}^{2}$ aperture placed in the plot at random distances along the root coring transects (see below). The material was sorted into leaf mass and non-leaf material (including bark, twigs and reproductive organs). Twenty leaves per bucket were selected by random and analyzed individually for their area with the software WinFolia 2001a (Régent, Quebec, Canada).

\section{Analysis of fine root mass, morphology and distribution}

Soil coring and associated fine root analysis was conducted for three purposes, (i) to estimate the root biomass and necromass of the four tree species in the stand, 
(ii) to analyse the vertical and horizontal fine root distribution by species, and (iii) to compare the four coexisting species with respect to fine root morphological properties.

Fine root $(\mathrm{d} \leq 2 \mathrm{~mm})$ sampling was conducted in June 2002 with sharp soil corers $(\mathrm{d}=35 \mathrm{~mm})$ that were manually driven into the topsoil to a depth of $250 \mathrm{~mm}$. Coring was conducted at 60 locations that were selected by random on three transects of $30 \mathrm{~m}$ length (20 locations per transect). The transects were demarcated at a distance of about $5 \mathrm{~m}$ to each other in the north-western part of the study plot where all four tree species occurred in quantities corresponding to their presence in the entire plot, where the mean stem distance was about $7 \mathrm{~m}$ and no marked clumping of stems occurred. A clumping of stems would have complicated a spatial analysis of fine root mass in the stand. The exact position of the root coring locations in the plot was recorded with the aim to analyse the dependence of root biomass on the distance to the closest stem, tree species identity, and basal area of the surrounding stems. In the analysis of the relationship between belowground and aboveground biomass structure, all stems within a radius of $5 \mathrm{~m}$ around a coring location were considered.

The soil cores were sliced into organic layer, upper $(0-10 \mathrm{~cm})$ and lower $(10-20 \mathrm{~cm})$ mineral soil horizons, transferred to plastic bags, sealed, and transported to the laboratory where the processing of the stored samples $\left(4^{\circ} \mathrm{C}\right)$ took place within four weeks (Tierney and Fahey 2001). We restricted root coring to the organic layer and the 0-20 cm layer of the mineral soil, since earlier investigations in the Ziegelrodaer Forst had shown that fine root biomass decreases exponentially with soil depth and that the 0-20 cm section of the soil profile contained about $60 \%$ of the total fine root biomass of the stand (Hertel 1999).

The samples were cleaned from soil using a water jet and a $0.25 \mathrm{~mm}$ sieve. Fine roots of the four tree species were separated under the binocular (16-40×) according to colour, periderm surface structure and ramification. Hertel (1999), Hölscher et al. (2002) and Korn (2004) developed a preliminary key for distinguishing fine roots of Fagus, Quercus, Carpinus and Tilia based on a set of morphological criteria, which was applied here. Live (biomass) and dead rootlets (necromass) were distinguished by colour, root elasticity and the degree of cohesion of cortex, periderm and stele. A non-turgid cortex and stele, an air-filled stele, or the complete loss of the stele and cortex with only the periderm being present, were used as indicators of root death (Leuschner et al. 2004). Herb roots occurred only at very low densities in the stand; they were discarded. Large fine root fragments (length $\geq 10 \mathrm{~mm}$ ) were extracted by hand, smaller fragments 
were determined in sub-samples ( $n=8$ per soil horizon) by spreading the remaining sieve content on a piece of filter paper $\left(730 \mathrm{~cm}^{2}\right)$ with 36 squares marked on it (Van Praag et al. 1988). Six of the squares were randomly selected and analysed in a time-consuming procedure under the binocular for even smallest fine root fragments. The mass of small fragments was then extrapolated to all samples by quantifying the ratio between large and small root fragments in a sub-sample. All samples were ovendried $\left(48 \mathrm{~h}, 70^{\circ} \mathrm{C}\right)$ to constant weight.

The root mass data were expressed per ground area $\left(\mathrm{g} \mathrm{m}^{-2}\right.$ to a depth of $\left.20 \mathrm{~cm}\right)$ and as biomass/necromass ratio for each tree species. Coring locations, where all surrounding stems within a $5 \mathrm{~m}$ radius belonged to one species, were termed 'mono-specific coring locations'; 'multi-species coring locations' were surrounded by stems of two to four tree species.

For investigating root morphology, 29 to 49 fresh fine root samples per species and soil horizon were extracted and analysed for specific fine root surface area (SRA, in $\mathrm{cm}^{2} \mathrm{~g}^{-1}$, only fraction $\leq 2 \mathrm{~mm}$ in diameter considered) using a flat-bed scanner and the image analysis program WinRhizo 2002a (Régent, Quebec, Canada). By multiplying SRA with fine root biomass in the horizons, a fine root area index (RAI, in $\mathrm{m}^{2}$ per $\mathrm{m}^{2}$ ground area) was obtained. The specific abundance of live fine root tips (n per mg root dry mass) was also counted under a stereo-microscope.

\section{Root chamber experiments on fine root competition}

Hertel and Leuschner (2006) introduced the in situ-root growth chamber technique for monitoring fine root growth of trees in the soil of mature forests under conditions of manipulated root neighbourhoods (see Fig. A 3). This approach allows conducting replicated experiments on competitive interactions between tree fine roots under field conditions in intact forests. Our chambers partly resemble the root chambers developed by Mahall and Callaway (1991), Espeleta et al. (1998), and Escamilla and Comerford (1998) for studying nutrient depletion, root communication or the functioning of mycorrhizal roots in the rhizosphere. We applied this technique for quantifying competition between fine roots of all four species (interspecific competition) and compared the results with the outcome of intraspecific competition treatments. The technique and its application are described in detail in Hertel and Leuschner (2006). Briefly, 335 root growth chambers manufactured from opaque PVC plates with a volume of $189 \mathrm{~cm}^{3}$ (90 x $70 \times 30 \mathrm{~mm}$ length, height and width; Fig. A 3) were used in the stand. The cham- 
ber's front and back sides were perforated with 36 holes $(\mathrm{d}=1 \mathrm{~mm})$ each, and the top and bottom consisted of plastic gauze $(\mathrm{d}=1.5 \mathrm{~mm})$ to permit sufficient water percolation and gas exchange but to prevent root ingrowth from the surrounding soil.

We investigated ten different competitive root interactions (six possible interspecific interactions between each two species, four intraspecific interactions) by placing two terminal fine roots in each chamber and exposing them for 180 to $210 \mathrm{~d}$ in the topsoil in situ. The chambers were covered by a layer of soil or litter. Live terminal fine roots were carefully uncovered in the uppermost soil with a pair of tweezers and small spoons, and inserted through one of the two openings $(\mathrm{d}=6.5 \mathrm{~mm})$ at the two opposite side walls. By this procedure, the mycorrhizal mycelium in the rhizosphere was cut but the terminal finest roots and their root tips remained intact and typically continued growth within a few weeks inside the chamber (Hertel and Leuschner 2006). After 6 months of exposure in the chambers, the majority of roots were intensively reinfected by mycorrhizal fungi and showed vital growth. The roots selected for study had a diameter at the point of insertion of $2 \mathrm{~mm}$; approximately $30 \mathrm{~mm}$ of the terminal root section was enclosed in the chamber. Since the two root endings partly overlapped in the chamber, competitive interactions must have occurred in the experiments. The species identity of the roots was detected in situ from periderm morphology and colour as described above. In the case of experiments on interspecific root competition, the study objects were fine roots of two different species; intraspecific competition was investigated with two conspecific roots in a chamber. The chambers were filled with root-free mineral soil extracted from the direct vicinity and the roots were carefully embedded in this substrate which more or less resembled the undisturbed soil environment in the stand.

We attempted to accommodate each of the ten studied interaction types with at least 30 chambers to allow for a statistical analysis of the data. At the date of harvest, the branch roots were cut at the insertion holes, carefully extracted from the chamber and their dry mass $\left(48 \mathrm{~h}, 70^{\circ} \mathrm{C}\right)$ and length increment were determined in the laboratory. Root performance was assessed as root relative growth rate (RGR in $\mathrm{mg} \mathrm{g}^{-1} \mathrm{~d}^{-1}$ ) between insertion date and date of harvest. The initial biomass of the two inserted fine roots was estimated non-destructively by photographing the root in front of a graph paper at the beginning of the experiment and calculating root length/dry mass relationships from root samples taken close to the chambers. 
For quantifying a species' ability to compete successfully with the roots of other tree species for soil space and soil resources, we defined a competitive ability index (CA) which uses fine root RGR as a fitness parameter in the belowground compartment. We assumed that root growth is closely linked to an increase in absorbing surface area and thus to a growing nutrient and water absorption capacity of the fine root system. A species' RGR in interspecific interaction (two-species chambers, $R_{G R}$ mix ) was contrasted with its RGR in intraspecific interaction (single-species chambers, RGR $_{\text {mono }}$ ) with

$$
\mathrm{CA}=\left(\mathrm{RGR}_{\text {mix }}-\mathrm{RGR}_{\text {mono }}\right) \times \mathrm{RGR}_{\text {mono }}{ }^{-1}
$$

Positive CA values stand for a better root growth with an allospecific root than with a conspecific one. For assessing the competitive ability of a tree species in all possible interspecific interactions in this four-species stand, all three CA values of a species were averaged. Similar CA values of two competing species were interpreted as an indication of a quasi-symmetric competitive interaction, irrespective of the absolute size of RGR of the two species. On the other hand, we assumed the larger the species differences in $\mathrm{CA}$, the more asymmetric the interaction to be.

Using root RGR as criterion to assess belowground competitive ability follows the general practice in competition experiments with herbaceous pot-grown plants (Grace 1995). This species-centred approach of belowground competitive ability contrasts with the concept adopted by Schenk (2006) who focuses on the community-level consequences of belowground competition by defining root competition to be 'a reduction in the availability of a soil resource to roots that is caused by other roots'.

We were not able to reach a balanced experimental design in the root chamber study because the fine roots of the four species occurred at different abundances in the soil. Additionally, root species identification in the field was erroneous in various cases. Thus, several species combinations were represented with only a few chambers, while others could be accommodated with more than 30 replicates because the root species combination was particularly abundant. Furthermore, it turned out upon harvest that, in about $5 \%$ of the chambers, the roots had not grown at all, or the experiment was disturbed by the ingrowth of additional fine roots from the surrounding soil (3\%). Possible causes of zero root growth were root damage during the insertion process, assumed low 
vitality of the roots at the start of the experiment, or other unknown factors. Therefore, chambers with relative growth rates $<0.001 \mathrm{mg} \mathrm{g}^{-1} \mathrm{~d}^{-1}$ were excluded from the analysis.

\section{Statistical analysis}

All data sets were tested for Gaussian distribution with a Shapiro-Wilk test. We used a parametric Scheffé's multiple comparison procedure to test for significant differences in tree height and fine root biomass among the four species. A non-parametric Mann and Whitney (Wilcoxon) two-sample test was used to determine if (i) tree species had different DBH means, (ii) root growth rates were different in the root chamber treatments, (iii) the species differed with respect to fine root morphology, and (iv) the species differed in their relative competitive abilities. These calculations were conducted with the SAS System for Windows 8.02 (SAS Institute, Cary, NC, USA). Linear and non-linear regressions were calculated with the program Xact 8.03 (SciLab, Hamburg, Germany).

\subsection{RESULTS}

\section{Aboveground forest structure and productivity of the four tree species}

The four-species mixed stand in the Ziegelrodaer Forst showed very different stem numbers and basal areas for Carpinus, Fagus, Quercus and Tilia. Quercus was the most abundant tree species with $40 \%$ of the stems and $53 \%$ of the basal area in this stand, followed by Carpinus (stems: 47\%, basal area: 25\%) and Fagus (10 and 19\%, respectively). Tilia contributed less than $4 \%$ of the stems and of the basal area (Table 4.1). In contrast, relative basal area increment (in \%o of the existing basal area) in the period January to September 2002 tended to be higher in Fagus than in all other species (Fig. 4.1, only the difference Fagus-Tilia significant), and thus was not related to a species' abundance in the stand. The leaf area index (LAI) was significantly different between the four species; LAI of all trees in the stand totalled at $7.8 \mathrm{~m}^{2} \mathrm{~m}^{-2}$ (Table 4.1). 


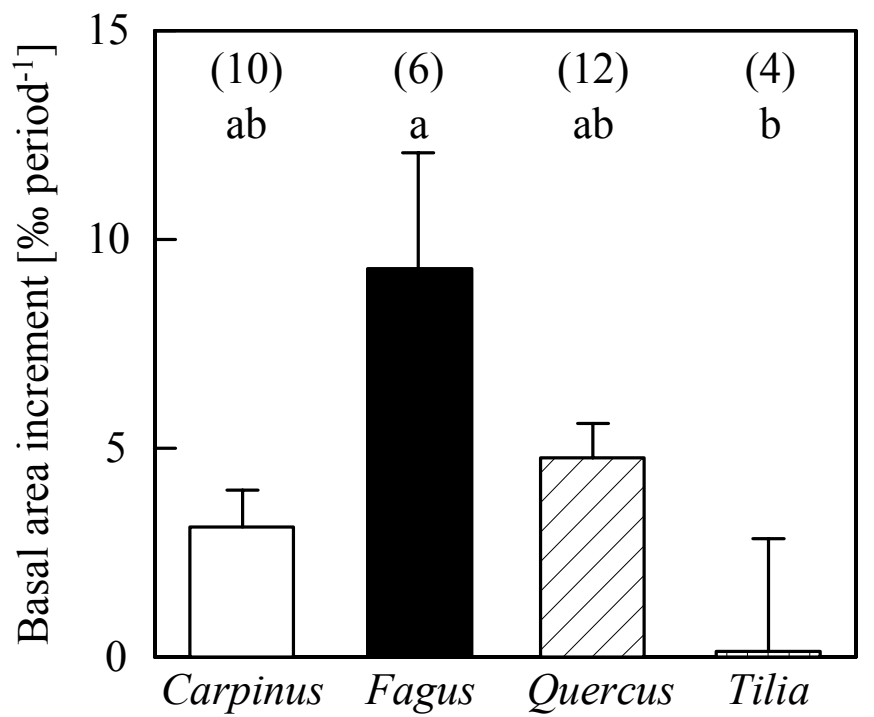

Fig. 4.1 Mean basal area increment (in \%o of the existing basal area) in the period January - September 2002 of the four tree species in the study plot (mean+SE, $n=4-12$ trees per species). Significant differences between the species are indicated by different letters (U-test after Mann and Whitney, $\mathrm{p}<0.05$ ).

\section{Fine root mass of the four species}

No significant relationship between a species' basal area and its fine root biomass existed in the stand. Quercus with 53\% of the basal area and an annual stem wood production of $1.2 \mathrm{Mg} \mathrm{ha}^{-1}$ contributed only $11 \%$ of the stand total of fine root biomass, whereas Fagus (19\% of basal area) and Carpinus (25\%) with 0.4 and $0.1 \mathrm{Mg} \mathrm{ha}^{-1}$ of stem wood production were over-represented in root biomass (32 and 51\%, respectively; Fig. 4.2).

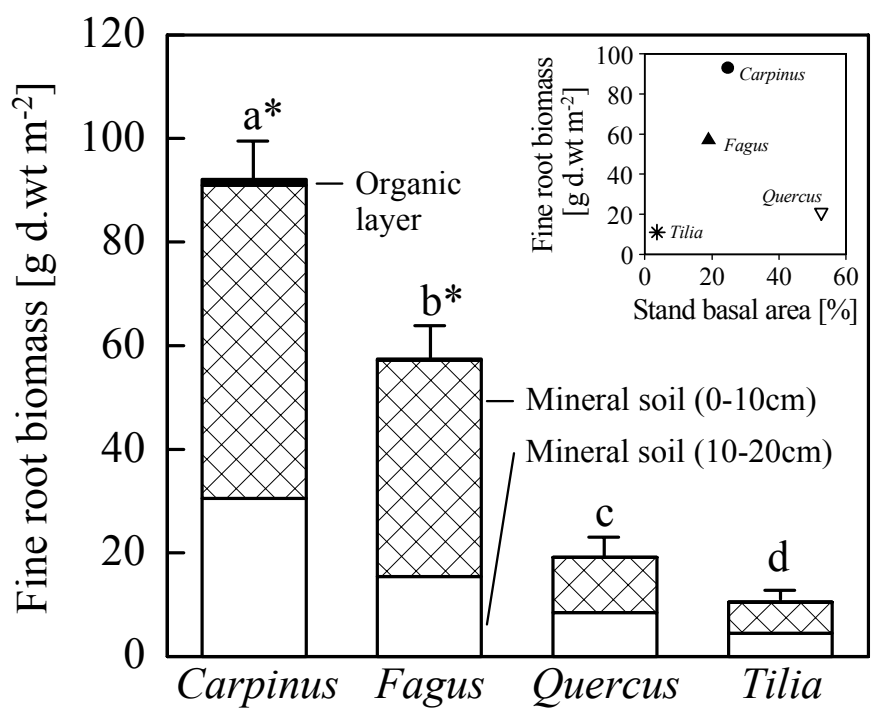

Fig. 4.2 Fine root biomass of the four tree species in the organic layer and two mineral soil horizons (0-10 and $10-20 \mathrm{~cm})$ of the study plot $(n=59$, mean+SE). Inlet: relationship between relative stand basal area and fine root biomass for the four species in the stand. Significant differences between the species are indicated by different letters (U-test after Mann and Whitney, $\mathrm{p}<0.05$ ). Asterisks denote significant differences between upper and lower mineral soil horizon. 
Relating fine root biomass to stem increment yielded quotients of 150 to $1000 \mathrm{~g}$ root biomass per $\mathrm{Mg} \mathrm{ha}^{-1}$ of stem increment in Carpinus, Fagus and Tilia, but only $17 \mathrm{~g}$ per $\mathrm{Mg} \mathrm{ha}^{-1}$ in Quercus.

We found twice as much fine root necromass in the profile to $20 \mathrm{~cm}$ depth than root biomass with Carpinus contributing by far the largest proportion $(>50 \%)$ of dead roots (Table 4.2). Fagus had a significantly higher biomass/necromass ratio (0.84) than Tilia, Carpinus and Quercus (0.45-0.79).

Table 4.2 Necromass, biomass:necromass ratio, and root area index (RAI) of fine roots of the four tree species in soil profiles (organic layer and $0-20 \mathrm{~cm}$ of mineral soil) of the study plot (mean $\pm \mathrm{SE}, n=59$ ). Significant differences between the species are indicated by different letters (U-test after Mann and Whitney, $\mathrm{p}<0.05)$.

\begin{tabular}{lcccc}
\hline & $\begin{array}{c}\text { Fine root necromass } \\
\text { [g d.wt } \mathbf{~ m}^{-2} \text { ] }\end{array}$ & $\begin{array}{c}\text { Fine root bio- } \\
\text { mass:necromass ratio }\end{array}$ & $\begin{array}{c}\text { Fine root area index } \\
{\left[\mathbf{m}^{2} \mathbf{~ m}^{-2} \text { ] }\right.}\end{array}$ \\
\hline Carpinus & $190.4 \pm 16.8 \mathrm{a}$ & $0.45 \pm 0.03 \mathrm{~b}$ & $2.4 \pm 0.4 \mathrm{a}$ \\
Fagus & $94.4 \pm 19.2 \mathrm{~b}$ & $0.84 \pm 0.08 \mathrm{a}$ & $1.4 \pm 0.3 \mathrm{~b}$ \\
Quercus & $57.0 \pm 4.1$ & $\mathrm{~b}$ & $0.54 \pm 0.10 \mathrm{~b}$ & $0.5 \pm 0.3 \mathrm{c}$ \\
Tilia & $21.4 \pm 5.7$ & $\mathrm{c}$ & $0.79 \pm 0.16 \mathrm{~b}$ & $0.2 \pm 0.2 \mathrm{~d}$ \\
\hline
\end{tabular}

Fine root morphology was not significantly different between the four species with respect to specific root surface area (SRA), the relative proportion of finest roots $(\leq 1 \mathrm{~mm}$ in diameter) in fine root biomass, and specific root tip frequency (Table 4.3).

Table 4.3 Proportion of finest roots (diameter $d \leq 1 \mathrm{~mm})$ in fine root biomass $(\mathrm{d} \leq 2 \mathrm{~mm})$, specific fine root surface area (SRA), and specific root tip frequency of the four tree species in the mineral soil $(0-20 \mathrm{~cm}$, mean $\pm \mathrm{SE}, n=$ sample size $)$. Different letters indicate significant differences between the species (U-test after Mann and Whitney, $\mathrm{p}<0.05$ ).

\begin{tabular}{lcccc}
\hline & $\boldsymbol{n}$ & $\begin{array}{c}\text { Proportion of finest } \\
\text { roots [\%] }\end{array}$ & $\begin{array}{c}\text { Specific root area } \\
{\left[\mathbf{c m}^{\mathbf{2}} \mathbf{~ g}^{-\mathbf{1}}\right]}\end{array}$ & $\begin{array}{c}\text { Specific root tip fre- } \\
\text { quency }\left[\mathbf{n} \mathbf{~ m g}^{-1}\right]\end{array}$ \\
\hline Carpinus & 44 & $88.2 \pm 1.8 \mathrm{a}$ & $349.2 \pm 28.8 \mathrm{a}$ & $26 \pm 4 \mathrm{a}$ \\
Fagus & 49 & $90.2 \pm 2.1 \mathrm{a}$ & $315.4 \pm 19.0 \mathrm{a}$ & $17 \pm 2 \mathrm{a}$ \\
Quercus & 36 & $95.7 \pm 1.4 \mathrm{a}$ & $325.5 \pm 39.1 \mathrm{a}$ & $23 \pm 4 \mathrm{a}$ \\
Tilia & 29 & $90.0 \pm 3.6 \mathrm{a}$ & $415.9 \pm 73.3 \mathrm{a}$ & $18 \pm 5 \mathrm{a}$ \\
\hline
\end{tabular}

However, Tilia tended to have a higher SRA, and Fagus and Tilia a lower root tip frequency than the other species. The fine root area index (RAI) of all trees in the stand totalled at $4.5 \mathrm{~m}^{2} \mathrm{~m}^{-2}$ (profile to $20 \mathrm{~cm}$ soil depth) with particularly large contributions by Carpinus and Fagus (Table 4.2). The ratio between LAI and RAI varied considera- 
bly between 6.5 for Quercus and 0.7 for Carpinus. The ratios of Fagus and Tilia (1.6 and 2.4) were much more balanced.

\section{Spatial distribution of fine roots and overlap among different species}

The identification of fine roots by species allowed us to analyse species-specific fine root abundances in horizontal and vertical direction in the soil of the mixed stand. All species exhibited stem-centred distribution patterns with the highest biomass of a species regularly occurring at distances of less than $5 \mathrm{~m}$ around the stem (Fig. 4.3).
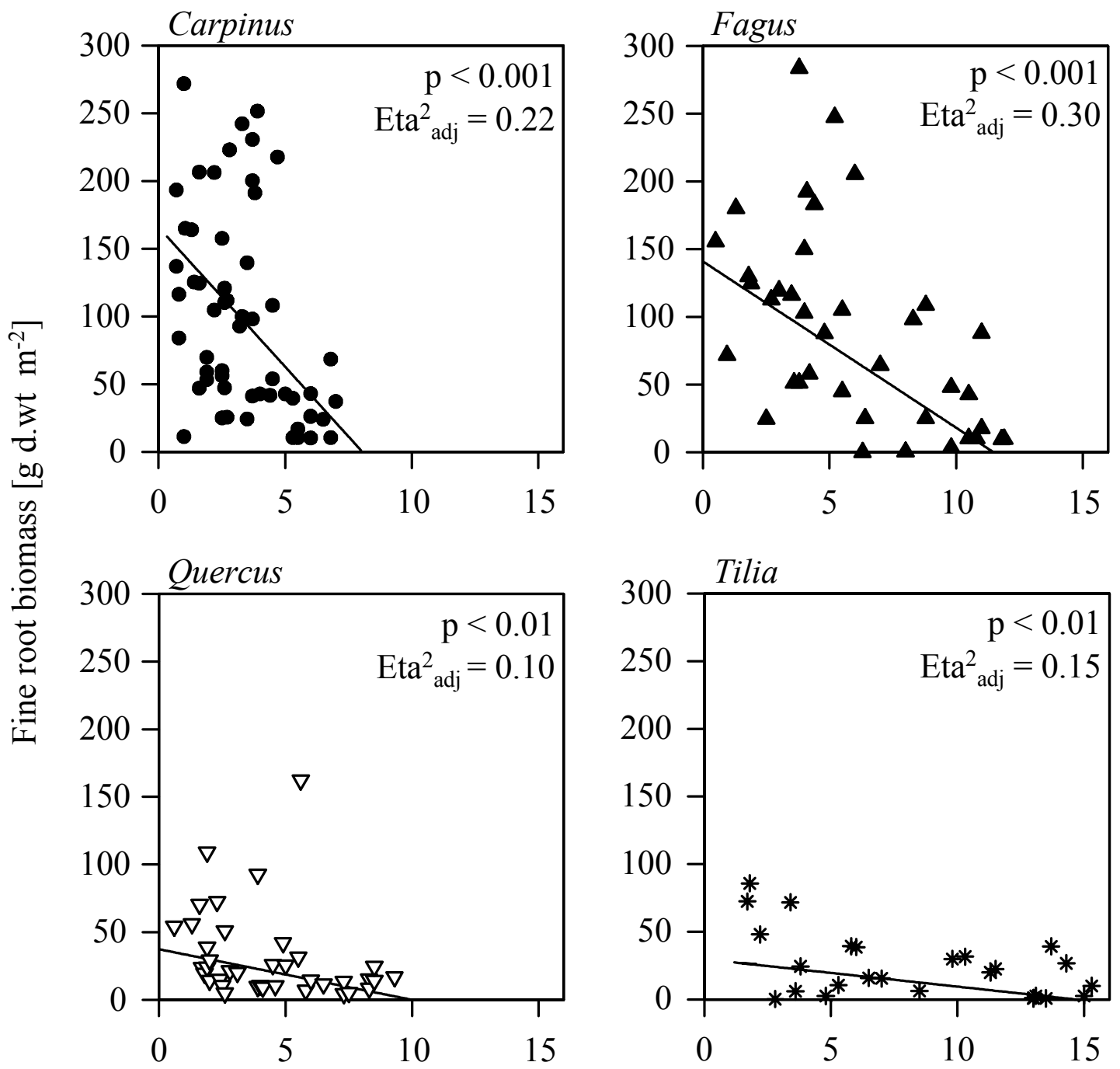

Distance to the next conspecific tree stem [m]

Fig. 4.3 Relation between cumulative fine root biomass of a species in the soil (organic layer and 0-20 cm of mineral soil) of the study plot and distance to the nearest conspecific stem $(n=59$ soil samples).

Species-specific fine root density decreased more rapidly with stem distance in Carpinus and Fagus, which generally had higher fine root biomasses in the stand, than 
in Quercus and Tilia, species with a comparably low density. The maximum horizontal extension of fine roots was estimated at $15 \mathrm{~m}$ for Tilia; in the other three species, we were not able to detect root system radii $>7-12 \mathrm{~m}$ because distances between conspecific stems were shorter than in the rare species Tilia.

The $0-20 \mathrm{~cm}$ mineral soil was densely explored by tree fine roots, and the root systems of the four species overlapped extensively. More than $50 \%$ of all investigated soil samples contained roots of two species; about $25 \%$ were explored by 3 or 4 species. Only one species was present in about $25 \%$ of the samples. The thin organic layer (5 to $30 \mathrm{~mm}$ in depth) contained only roots of Fagus and Carpinus, the two species with the largest total fine root biomass in the stand (Table 4.4).

Table 4.4 Relative frequency of soil samples containing fine roots of 1 to 4 tree species (or no roots at all) in three soil layers (in percent, $n=59$ ).

\begin{tabular}{lccc}
\hline $\begin{array}{l}\text { Number of tree species } \\
\text { present with their fine } \\
\text { roots }\end{array}$ & Organic layer & $\begin{array}{c}\text { Mineral soil } \\
(\mathbf{0 - 1 0} \mathbf{~ c m})\end{array}$ & $\begin{array}{c}\text { Mineral soil } \\
(\mathbf{1 0 - 2 0} \text { cm) }\end{array}$ \\
\hline No fine roots & 59.3 & 0 & 0 \\
1 & 33.9 & 23.4 & 17.2 \\
2 & 6.8 & 48.3 & 60.3 \\
3 & 0 & 23.3 & 15.6 \\
4 & 0 & 5.0 & 6.9 \\
\hline
\end{tabular}

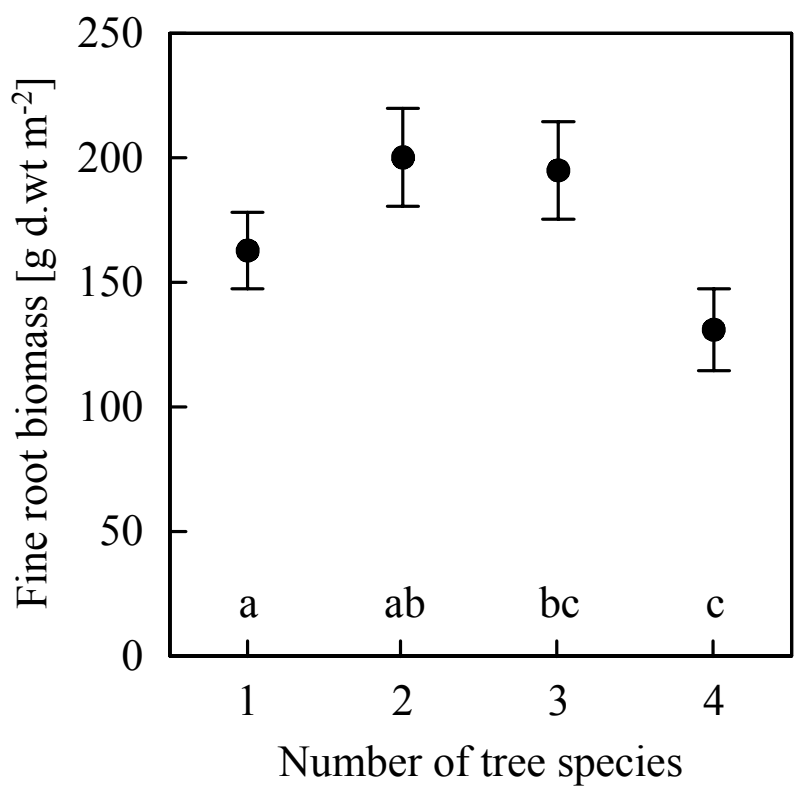

Fig. 4.4 Cumulative fine root biomass (of all four tree species) in the soil (organic layer and 0-20 $\mathrm{cm}$ of mineral soil) as dependent on the number of tree species being present by their roots in that location (mean \pm SE, $n=59$ ). Significant differences between locations with 1, 2, 3 or 4 root species are indicated by different letters (U-test after Mann and Whitney, $\mathrm{p}<0.1$ ). 
Soil patches, in which fine roots of two or three species were present in the profile to $20 \mathrm{~cm}$ depth, tended to have higher total fine root biomasses than patches with the roots of one or four tree species (Fig. 4.4). However, the difference between soil patches with one and two, or between three and four species, was significant only at $\mathrm{p}<0.1$.

\section{Apparent neighbour effects on fine root biomass}

Different root abundances of a target species in forest patches, in which either conspecific or allospecific tree species were dominant aboveground, may give hints on a species' belowground competitive ability in interspecific interactions. For each of the four species, we compared the fine root biomass in forest patches, where either all surrounding

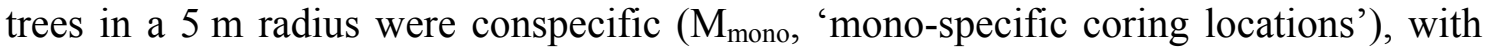
patches, where part of the trees were allospecific $\left(\mathrm{M}_{\text {mix }}\right.$, 'multi-species coring locations'). As expected, a species' fine root biomass in the $0-20 \mathrm{~cm}$ profile tended to be higher in the mono-specific coring locations than in the multi-species locations for all four species (Table 4.5).

Table 4.5 Fine root biomass (in $\mathrm{g} \mathrm{d}_{\mathrm{wt}} \mathrm{m}^{-2}$ ) in soil profiles (organic layer and 0-20 $\mathrm{cm}$ of mineral soil) in soil patches surrounded either by conspecific stems ('mono-specific coring locations') or by one or more allospecific stems ('multi-species coring locations') within a $5 \mathrm{~m}$ radius. The biomass ratio in multispecies to mono-specific locations is given as well. Significant differences between the fine root biomass in mono-specific and multi-species locations are indicated by different small letters (Scheffé test, $\mathrm{p}<0.05$ ), significant differences between the tree species by different capitals (Scheffé test, $\mathrm{p}<0.1$, mean \pm SE, $n=$ sample size).

\begin{tabular}{lcccccc}
\hline Species & $\begin{array}{c}\text { Mono-specific cor- } \\
\text { ing locations }\end{array}$ & $\boldsymbol{n}$ & $\begin{array}{c}\text { Multi-species cor- } \\
\text { ing locations }\end{array}$ & $\boldsymbol{n}$ & $\begin{array}{c}\text { Multi-species/ mono- } \\
\text { specific ratio }\end{array}$ \\
\hline Carpinus & $144.8 \pm 18.9 \mathrm{Aa}$ & 14 & $122.8 \pm 14.9$ & $\mathrm{Aa}$ & 22 & $0.84 \pm 0.10$ \\
Fagus & $149.2 \pm 12.8 \mathrm{ABa}$ & 4 & $121.0 \pm 23.6$ & $\mathrm{Aa}$ & 9 & $0.81 \pm 0.19$ \\
Quercus & $68.3 \pm 14.9 \mathrm{Ba}$ & 5 & $32.8 \pm 11.2$ & $\mathrm{Ba}$ & 14 & $0.48 \pm 0.16$ \\
Tilia & $60.6 \pm 10.0 \mathrm{Ba}$ & 5 & $9.9 \pm 7.4$ & $\mathrm{Bb}$ & 5 & $0.16 \pm 0.13$ \\
\hline
\end{tabular}

However, only in the case of Tilia, the $\mathrm{M}_{\mathrm{mix}}-\mathrm{M}_{\text {mono }}$ difference was large and significant at $\mathrm{p}<0.05$. In Quercus, the difference was marginally significant $(\mathrm{p}<0.1)$. Carpinus and Fagus showed only non-significant differences in root biomass between mono-specific and multi-species coring locations. A large root biomass reduction in the presence of allospecific trees is reflected by small $\mathrm{M}_{\text {mix }} / \mathrm{M}_{\text {mono }}$ ratios as in Tilia and Quercus (0.16 and 0.48), a small reduction by high ratios as in Carpinus and Fagus (0.84 and 0.81). 


\section{In situ-root competition experiments}

In the in situ-root growth chamber experiments, Quercus, Tilia and, in part, Carpinus showed highest relative growth rates (RGR) of their fine roots when exposed with a conspecific root (the differences in growth rates between intra- and interspecific competition treatments were only partly significant at $\mathrm{p}<0.05$, Table 4.6). Fagus fine roots, in contrast, grew significantly better in the neighbourhood of a Quercus or Carpinus root than in proximity to a conspecific root (the differences in growth rates between intraand interspecific competition treatments were only partly significant at $\mathrm{p}<0.05$ ).

Table 4.6 Relative growth rate of fine roots (RGR, $\mathrm{mg} \mathrm{g}^{-1} \mathrm{~d}^{-1}$ ) of target species (rows) as dependent on the presence of roots of competitors (columns) in in situ-root growth chambers that were exposed for 180-210 d in the topsoil. Mixed-species chambers contained fine roots of two species (intraspecific competition), single-species chambers two fine roots of the same species (intra-specific competition, in frames). Significant differences in root RGR of a target species in the four treatments are indicated by different letters (U-test after Mann and Whitney, $\mathrm{p}<0.05$, mean $\pm \mathrm{SE}$, number of replications given in parentheses).

\begin{tabular}{|c|c|c|c|c|}
\hline $\begin{array}{r}\text { Competitor } \\
\text { Target Species }\end{array}$ & Carpinus & Fagus & Quercus & Tilia \\
\hline Carpinus & $1.8 \pm 0.1 \mathrm{a}(153)$ & $1.6 \pm 0.2 \mathrm{ab}(64)$ & $1.0 \pm 0.2 \mathrm{c} \quad$ (29) & $1.1 \pm 0.2 \mathrm{bc}$ \\
\hline Fagus & $2.0 \pm 0.2 \mathrm{a} \quad(64)$ & $1.1 \pm 0.2 \mathrm{~b} \quad(82)$ & $1.5 \pm 0.5 \mathrm{ab}(16)$ & $0.7 \pm 0.3 \mathrm{~b}$ \\
\hline Quercus & $1.7 \pm 0.3 \mathrm{a} \quad$ & $2.1 \pm 0.5 \mathrm{a} \quad(16)$ & $2.4 \pm 0.6 \mathrm{a} \quad(6)$ & $1.3 \pm 0.7 \mathrm{a}$ \\
\hline Tilia & $1.6 \pm 0.3 \mathrm{a} \quad(35)$ & $1.5 \pm 0.3 \mathrm{a} \quad(16)$ & $1.8 \pm 0.5 \mathrm{a}$ & $1.9 \pm 0.7$ a $\quad(65)$ \\
\hline
\end{tabular}

The competitive ability index CA, which is defined as fine root RGR of the target species in intraspecific interaction vs. interspecific interaction with the three other tree species, showed large differences between the four species and was highest for Fagus $(+0.30)$ and lowest for Quercus (-0.25); Tilia and Carpinus ranked in-between $(+0.03$ and -0.15; Fig. 4.5). 


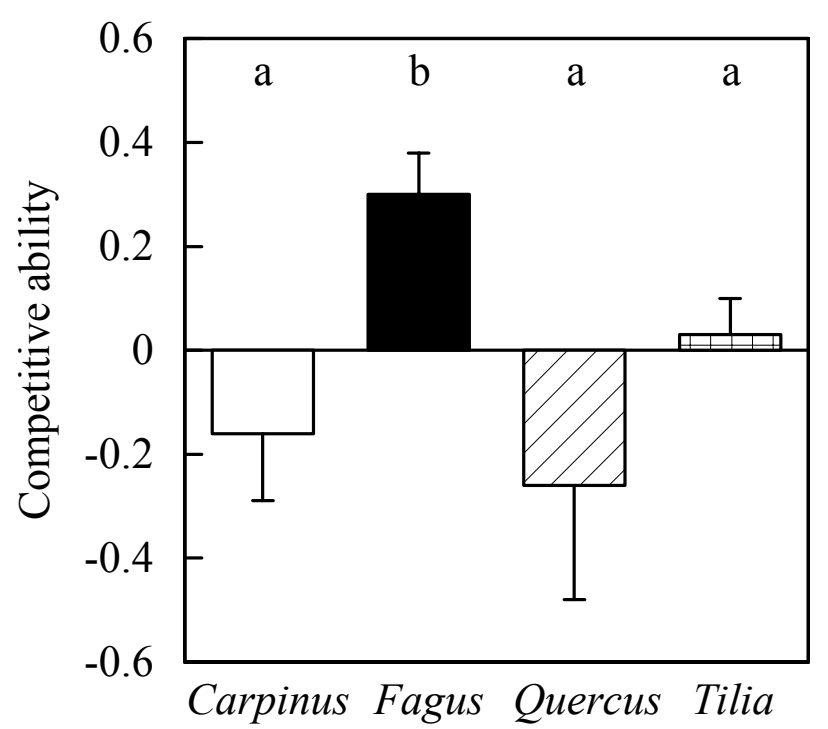

Fig. 4.5 Competitive ability CA (for definition see text) for interspecific competitive interactions of fine roots in relation to intraspecific interactions in the four tree species according to fine root growth experiments in in situ-root growth chambers. The CA values for all possible three interspecific interactions per species were averaged to obtain a species mean. Different letters indicate significant differences in CA values between the species (U-test after Mann and Whitney, $\mathrm{p}<0.05$ ). Mean $\pm \mathrm{SE}$ for 128, 96, 50, and 56 interspecific chambers of Carpinus, Fagus, Quercus and Tilia, respectively.

\subsection{DISCUSSION}

\section{Relationship between aboveground and belowground structures}

The fine root systems had a far larger horizontal extension than the corresponding tree crowns in the four-species mixed stand. This observation is in accordance with various other root inventories in forests, orchards and agroforestry systems (Kochenderfer 1973, Atkinson et al. 1976, Mou et al. 1995, Johnsen et al. 2005). Tilia trees spread their fine roots over an area of about $700 \mathrm{~m}^{2}$ (radius $\approx 15 \mathrm{~m}$ ), which is roughly ten times the size of the crown projection area (data not shown). A much larger size of the root system compared to the crown area was already reported for deciduous trees by Stout (1956) who found a mean ratio of $4.5: 1$ for crown vs. root system area. For Fagus, Quercus and Tilia, we found a gradual decrease in fine root density with increasing stem distance within a radius of $10 \mathrm{~m}$ or more, but not a strict stem-centred distribution pattern as it was observed, for example, in spruce forests by Bédéneau and Auclair (1989) and Nielsen and Mackenthun (1991). Only in the case of Carpinus, fine root biomass showed a steep decrease within a $7 \mathrm{~m}$-radius around the stems. We assume that stemcentred fine root distributions as in Carpinus are a consequence of the numerous premature hornbeam trees in this stand which are forming a second canopy layer and may 
not have reached the root system's maximum size in this stand. Given the high degree of root system overlap with $75 \%$ of the soil volume being explored by at least two or three different species, there are no indications of a spatial segregation ('territoriality') of whole fine root systems in this stand as was suggested by Lyford and Wilson 1964, Schenk et al. (1999) and others. Our results, based on soil core analyses, are not precluding root segregation at a millimetre or centimetre scale as reported by Caldwell et al. (1996).

The four tree species differed largely with respect to their presence in terms of fine root biomass and root surface area in the soil volume of the mixed stand. Relating fine root biomass to aboveground structural parameters, Carpinus had a very high fine root biomass in relation to its aboveground biomass and productivity in the stand, followed by Fagus with slightly lower fine root biomass/stem increment biomass (FRB/ST) ratios. In contrast, Quercus was highly under-represented in the belowground compartment with more than 10 times smaller FRB/ST and FRB/stem biomass ratios than Carpinus. Although fine root biomass does not necessarily reflect belowground productivity, the very large differences in the belowground/aboveground carbon partitioning patterns between Quercus and the other three species are unexpected because nutrient and water availability in the shared soil volume are imposing similar constraints on the functionality of the root system of the four species in this stand. Other biometric parameters such as the sapwood area/leaf area ratio (Huber value) or the LAI to basal area ratio are also known to differ between coexisting tree species in mixed stands, but they are not different by a factor of ten (Ammer 2003, Burkes et al. 2003)

These apparent tree species differences in carbon allocation patterns may have genetic causes expressing different physiological constitutions, or they can be a consequence of asymmetric interspecific competition, which may lead to a suppression of inferior competitors belowground. Evidence for the second explanation will be assessed in the following.

\section{Evidence of asymmetry in belowground competition}

We found two lines of evidence for the existence of asymmetry in belowground competition in this mixed forest, (i) indirect evidence from a comparison of fine root abundances in mono-specific and multi-species patches of the stand, and (ii) direct evidence from root growth experiments in contrasting root neighbourhoods using root growth chambers. 
Our observation of an over-proportional reduction in fine root biomass of Quercus petraea in species-rich allospecific compared to monospecific stand patches in the Ziegelrodaer forest is supported by other studies in Central Europe. Büttner and Leuschner (1994) and Leuschner et al. (2001) found a 20\% contribution of Quercus fine roots to the stand total of fine root biomass in a Fagus-Quercus forest, even though oak held $50 \%$ of the basal area and $46 \%$ of the total leaf area in the stand. Over-proportional reduction in fine root biomass of target tree species in mixed stands has also been reported by e.g. Hendriks and Bianchi (1995), Rust and Savill (2000), and Schmid and Kazda (2002) for stands including Pseudotsuga menziesii, Fraxinus excelsior and Picea abies. Most likely, these patterns are the outcome either of asymmetric root competition or of indirect competitive interactions involving unknown negative third-party effects on the roots of the inferior species.

A comparatively low belowground competitive ability of Quercus is strongly supported by the results of our root competition experiments. Even though we were not able to accommodate all treatments with a sufficient number of replicates, which partly reduced the statistical significance of the results, there was a tendency for Quercus roots to grow slower when placed with Carpinus, Fagus and Tilia roots than when growing with conspecific roots. This fits to the root abundance data indicating that Quercus root RGR tended to be reduced in the presence of competing Carpinus or Fagus roots. A high belowground competitive ability of Fagus in mixture with Quercus is supported by an earlier competition experiment with root growth chambers in a two-species Fagus-Quercus stand on sandy soil (Hertel and Leuschner 2006).

Although the root growth chambers employed here were designed to simulate fine root growth in a soil environment as close to nature as possible, several artefacts are inherent to this method, most notably an initial disturbance of the mycorrhizosphere (see discussion in Hertel and Leuschner 2006). The growth experiments may also be biased by temporal patterns of fine root growth that could differ between the competing species, thereby influencing the outcome of competition experiments (Eissenstat and Caldwell 1988, Burke and Chambers 2003). However, the long period of exposure (180 to $210 \mathrm{~d}$ ) should have minimised this type of error in our experiment. Because the large majority of chambers showed vital fine root growth, resulting in largely overlapped root systems at harvest time, we believe that this method, if applied with a large number of replicates ( $>30$ per treatment), represents a promising approach to analyse root competition between trees with a statistically sound design in intact stands. Other approaches to study 
fine root growth in situ such as the minirhizotron technique (Hendrick and Pregitzer 1996, Majdi 1996) are not suitable for investigating root competition because they do not allow root neighbourhood manipulation. Walk-in rhizotron facilities provide a better opportunity for manipulative studies, but the root boxes are rarely large enough to accommodate mature trees (Lyford and Wilson 1966, Atkinson 1985, Smit et al. 1994).

Our empirical data are support for more recent spatial modelling studies and theoretical analyses which concluded that belowground competition should rather be asymmetric than symmetric when resources are distributed heterogeneously in the soil, thereby contradicting earlier assumptions on the outcome of root competition (Schwinning 1996, Schwinning and Weiner 1998, Bauer et al. 2004). For example, asymmetric root competition could take place where larger plants are able to occupy nutrient-rich soil patches (Van Lear and Kapeluck 1995). Indeed, Fagus and Carpinus, the two species with the largest total fine root biomass in the investigated stand, were the only trees species present in the organic layer. Furthermore, larger plants could have access to deeper soil water reserves and deplete them before smaller plants can gain access providing them with a disproportionate part of the soil resources (Robinson et al. 1999). Asymmetry of competition for nutrients and water should increase when resource supply is high but uptake kinetics differ between the species (Raynaud and Leadley 2005). The yet existing evidence of asymmetric root competition is from herbaceous plants and not from mature trees, and it is contradicting (Blair 2001, Fransen et al. 2001, Cahill and Casper 2000, Facelli and Facelli 2002, Rajaniemi 2003, von Wettberg and Weiner 2003). Our data seem to be among the first to prove asymmetric belowground competition in forests. They are supported by sap flow measurements in small-diameter absorbing roots which indicated different water uptake rates by the roots of co-occurring tree species in a temperate mixed stand (Korn, Burk and Leuschner, unpublished data).

\section{Fine root biomass of mixed forests - evidence for 'belowground overyielding'?}

In-depth analyses of tree root distribution in natural and managed mixed forests, orchards and agroforestry systems have produced growing evidence that root systems of coexisting species are often vertically stratified (Lyford and Wilson 1964, Casper and Jackson 1997, Schenk et al. 1999, Bennett et al. 2002, Yang et al. 2002, Bolte and Villanueva 2006, Li et al. 2006). However, observational studies as those cited cannot provide unequivocal evidence of the action of belowground competition. Species differences in root distribution or rooting depth in a shared soil volume could be the conse- 
quence of species differences in rooting patterns, thus reflecting a partial complementarity of the fundamental belowground niches (Connell 1980), or they could result from niche partitioning, i.e. a shift in the realized niches in response to asymmetric competition (Leuschner et al. 2001). This question can only be answered by comparing mixed and pure stands of the respective tree species (if they exist in nature) or, more directly, by experimental studies of synthetic tree stands differing in tree species composition (such as the 'BIOTREE' or the Sardinilla project, e.g. Scherer-Lorenzen et al. 2005). Alternative approaches are small-scale root neighbourhood manipulation experiments in the soil of intact stands as done in the present study.

A comparison of a tree species' root system in monospecific and mixed stands has only been conducted in a few case studies including McQueen (1968), Schmid (2002), Morgan et al. (1992), Leuschner et al. (2001) and Brandtberg et al. (2000). These studies produced controversial results with respect to increased belowground biomass production ('belowground overyielding') in species mixtures relative to monocultures. Schmid (2002) found a higher, Morgan et al. (1992) a lower fine root biomass in the twospecies stands compared to the respective mono-specific stands, while Brandtberg et al. (2000) and Leuschner et al. (2001) observed a similar fine root mass in one- and twospecies stands. While most of these studies compared one- and two-species stands, the present study is, to our knowledge, the only one which investigated a four-species stand. By comparing forest patches, where roots of one to four tree species coexisted in the soil, the present study provided only weak evidence of the existence of an 'overyielding' effect in the soil of this mixed forest. Soil patches containing the roots of two or three species tended to have a higher overall fine root biomass than patches with only one root species being present. However, this difference was only significant at $\mathrm{p}<0.1$. Moreover, the fact that patches containing the roots of four species tended to have particularly small total fine root biomasses and an often reduced root RGR in experiments with interspecific root neighbourhoods, does not support the hypothesis of 'belowground overyielding'. Further, the average profile total of fine root biomass in the Ziegelrodaer Forst (181 $\mathrm{g} \mathrm{m}^{-2}$ to $20 \mathrm{~cm}$ depth) was remarkably small compared to other mono-specific broad-leaved forests in the region (Hertel 1999, Leuschner and Hertel 2003) which makes belowground overyielding unlikely.

Clearly, data on fine root biomass are not comparable to hay yield data which were used to detect overyielding in synthetic grassland communities; by definition, overyielding exist when mixed stands show a higher aboveground productivity than any monoculture 
of the constituting species (Hector et al. 1999, Lambers et al. 2004, Roscher et al. 2005). Nevertheless, given the large methodological problems associated with fine root production measurements in mixed stands due to species identification, fine root biomass may serve as a first approximation of belowground productivity and tree fitness in forests.

In conclusion, not much evidence yet exists which shows a higher fine root biomass in temperate mixed forests compared to pure stands and, more important, the few available records are partly contradicting.

\section{Do the four tree species form a belowground competitive hierarchy?}

We used the contrasting fine root growth rates in intra- and interspecific competition treatments as a measure of a species' belowground interspecific competitive ability. According to the classical Lodka-Volterra competition model, stable coexistence between a pair of species will occur if both species inhibit their own growth through intraspecific competition more than they inhibit that of the other species through interspecific competition. Accordingly, the root growth patterns of Fagus in the root chambers with a lower RGR in single-species chambers than in the two-species chambers must be judged as a clear indication of a superior belowground competitive ability of beech in this stand. Alternative measures of competitive ability such as overall plant fitness or total productivity are not applicable in root competition studies with tall trees, although they would be more consistent with the widely accepted standard of measuring competition effects on plants (Grace 1995). Our root growth-related approach yielded a species ranking with respect to competitive ability in the sequence Fagus $>$ Tilia $>$ Carpinus $>$ Quercus.

Accordingly, root competition is size-asymmetric with superior and inferior species in this stand. Our experiments do not allow conclusions on the underlying mechanisms of this belowground interaction. In theory, at least three mechanisms are possible. (1) Different species may differ in their surface-specific water and/or nutrient uptake rates leading to resource pre-emption by the superior competitor (see the contrasting water uptake rates in trees discussed above, and Craine et al. 2005). (2) Unknown growth-reducing effects could act directly on the competitively inferior Quercus roots. (3) Self-self-discrimination could have occurred in the case of Fagus roots. Roots of the same species have been found to self-inhibit each other in certain herbaceous and shrubby species (Falik et al. 2003, 2005, Gruntman and Novoplansky 2004); this would 
lead to a lower growth rate in treatments with intra- compared to interspecific competition.

According to root biomass data in mono-specific and mixed Fagus/Picea forests, beech seems to be a superior competitor belowground not only in mixture with oak but also with spruce (Schmid and Kazda 2002). Hence, it appears that Fagus is a successful competitor belowground in a variety of Central European mixed forests, even though it is known that the competitive ability of a species can vary in dependence of the environment and the identity of the competing species. Moreover, in European beech, high belowground and aboveground competitive abilities seem to be linked to each other (Leuschner 1998) supporting Grime's (2001) hypothesis of a positive correlation between these two components of plant competition.

\subsection{CONCLUSION}

Our results show that, in this four-species stand, (i) the fine root systems of different tree species do not seem to be territorial but are broadly overlapping, (ii) root competition between trees can clearly be asymmetric, and (iii) tree species may be ranked according to their belowground competitive ability. Future experimental studies in the rhizosphere of forests have to reveal whether these findings apply to other mixed forests as well, and what mechanisms (including resource competition, self-self inhibition, facilitation, allelopathy, or indirect competitive interactions through other organisms or agents) underlie the observed root growth responses in the chambers. 


\subsection{REFERENCES}

Aikio S, Pakkasmaa S. 2003. Relatedness and competitive asymmetry - Implications for growth and population dynamics. Oikos 100: 283-290.

Ammer C. 2003. Growth and biomass partitioning of Fagus sylvatica L. and Quercus robur L. seedlings in response to shading and small changes in the R/FR-ratio of radiation. Annals of Forest Science 60: $163-171$.

Atkinson D. 1985. Spatial and temporal aspects of root distribution as indicated by the use of a root observation laboratory. Special publication of the British Ecological Society 4: 43-65.

Atkinson D, Naylor D, Coldrick GA. 1976. Effect of tree spacing on apple root-system. Horticultural Research 16: 89-105.

Bais HP, Vepachedu R, Gilroy S, Callaway RM, Vivanco JM. 2003. Allelopathy and exotic plant invasion: From molecules and genes to species interactions. Science 301: 1377-1380.

Barberis IM and Tanner EVJ. 2005. Gaps and root trenching increase tree seedling growth in Panamanian semi-evergreen forest. Ecology 86: 667-674.

Bauer S, Wyszomirski T, Berger U, Hildenbrandt H, Grimm V. 2004. Asymmetric competition as a natural outcome of neighbour interactions among plants: results from the field-of-neighbourhood modelling approach. Plant Ecology 170: 135-145.

Bédéneau M, Auclair D. 1989. The study of tree fine root distribution and dynamics using a combined trench and observation window method. Annals of Forest Science 46: 283-290.

Bennett JN, Andrew B, Prescott CE. 2002. Vertical fine root distributions of Western redcedar, Western hemlock, and salal in old-growth cedar-hemlock forests on northern Vancouver Island. Canadian Journal of Forest Research 32: 1208-1216.

Blair B. 2001. Effect of soil nutrient heterogeneity on the symmetry of belowground competition. Plant Ecology 156: 199-203.

Bolte A, Villanueva I. 2006. Interspecific competition impacts on the morphology and distribution of fine roots in European beech (Fagus sylvatica L.) and Norway spruce (Picea abies (L.) KARST.). European Journal of Forest Research 125: 15-26.

Bonanomi G, Giannino F, Mazzoleni S. 2005. Negative plant-soil feedback and species coexistence. Oikos 111: 311-321.

Brandtberg PO, Lundkvist H, Bengtsson J. 2000. Changes in forest-floor chemistry caused by a birch admixture in Norway spruce stands. Forest Ecology and Management 130: 253-264.

Burke MK, Chambers J. 2003. Root dynamics in bottomland hardwood forests of the southeastern United States Coastal Plain. Plant and Soil 250: 141-153.

Burkes EC, Will RE, Barron-Gafford GA, Teskey RO, Shiver B. 2003. Biomass partitioning and growth efficiency of intensively managed Pinus taeda and Pinus elliottii stands of different planting densities. Forest Science 49: 224-234.

Büttner V, Leuschner C. 1994. Spatial and temporal patterns of fine-root abundance in a mixed oak-beech forest. Forest Ecology and Management 70: 11-21.

Cahill JF, Casper BB. 2000. Investigating the relationship between neighbor root biomass and belowground competition: field evidence for symmetric competition belowground. Oikos 90: 311-320.

Caldwell MM, Manwaring JH, Durham SL. 1996. Species interactions at the level of fine roots in the field: Influence of soil nutrient heterogeneity and plant size. Oecologia 106: 440-447.

Campbell BD, Grime JP, Mackey JML. 1991. A trade-off between scale and precision in resource foraging. Oecologia 87: 532-538.

Casper BB, Jackson RB. 1997. Plant competition underground. Annual Review of Ecology and Systematics 28: 545-570. 
Connell JH. 1980. Diversity and the coevolution of competitors, or the ghost of competition past. Oikos 35: 131-138.

Coomes DA, Grubb PJ. 2000. Impacts of root competition in forests and woodlands: A theoretical framework and review of experiments. Ecological Monographs 70: 171-207.

Craine JM, Fargione J, Sugita S. 2005. Supply pre-emption, not concentration reduction, is the mechanism of competition for nutrients. New Phytologist 166: 933-940.

de Kroon H, Mommer L, Nishiwaki A. 2003. Root competition: Towards a mechanistic understanding. In: de Kroon K, Visser EJW. eds. Root ecology. Berlin, Germany: Springer, 215-235.

Eissenstat DM, Caldwell MM. 1988. Seasonal timing of root-growth in favorable microsites. Ecology 69: $870-873$.

Ellenberg H. 1996. Vegetation Mitteleuropas mit den Alpen in ökologischer, dynamischer und historischer Sicht. $5^{\text {th }}$ ed. Stuttgart, Germany: Ulmer.

Escamilla JA, Comerford NB. 1998. Measuring nutrient depletion by roots of mature trees in the field. Soil Science Society of America Journal 62: 797-804.

Espeleta JF, Eissenstat DM, Graham JH. 1998. Citrus root responses to localized drying soil: A new approach to studying mycorrhizal effects on the roots of mature trees. Plant and Soil 206: 1-10.

Facelli E, Facelli JM. 2002. Soil phosphorus heterogeneity and mycorrhizal symbiosis regulate plant intra-specific competition and size distribution. Oecologia 133: 54-61.

Falik O, Reides P, Gersani M, Novoplansky A. 2003. Self/non-self discrimination in roots. Journal of Ecology 91: 525-531.

Falik O, Reides P, Gersani M, Novoplansky A. 2005. Root navigation by self inhibition. Plant, Cell and Environment 28: 562-569.

Fargione J, Tilman D. 2005. Niche differences in phenology and rooting depth promote coexistence with a dominant C-4 bunchgrass. Oecologia 143: 598-606.

Fransen B, de Kroon H, Berendse F. 2001. Soil nutrient heterogeneity alters competition between two perennial grass species. Ecology 82: 2534-2546.

Grace JB. 1995. On the measurement of plant competition intensity. Ecology 76: 305-308.

Grime JP. 2001. Plant strategies, vegetation processes, and ecosystem properties. Chichester, UK: Wiley.

Gruntman M, Novoplansky A. 2004. Physiologically mediated self/non-self discrimination in roots. Proceedings of the National Academy of Science 101: 3863-3867.

Hector A, Schmid B, Beierkuhnlein C, Caldeira MC, Diemer M, Dimitrakopoulos PG, Finn JA, Freitas H, Giller PS, Good J, Harris R, Hogberg P, Huss-Danell K, Joshi J, Jumpponen A, Körner C, Leadley PW, Loreau M, Minns A, Mulder CPH, O'Donovan G, Otway SJ, Pereira JS, Prinz A, Read DJ, Scherer-Lorenzen M, Schulze ED, Siamantziouras ASD, Spehn EM, Terry AC, Troumbis AY, Woodward FI, Yachi S, Lawton, JH. 1999. Plant diversity and productivity experiments in European grasslands. Science 286: 1123-1127.

Hendrick RL, Pregitzer KS. 1996. Applications of minirhizotrons to understand root function in forests and other natural ecosystems. Plant and Soil 185: 293-304.

Hendriks CMA, Bianchi FJJA. 1995. Root density and root biomass in pure and mixed forest stands of Douglas-fir and beech. Netherlands Journal of Agricultural Science 43: 321-331.

Hertel D. 1999. Das Feinwurzelsystem von Rein- und Mischbeständen der Rotbuche: Struktur, Dynamik und interspezifische Konkurrenz. Berlin, Germany: Cramer.

Hertel D, Leuschner C. 2006. The in situ root chamber: A novel tool for the experimental analysis of root competition in forest soils. Pedobiologia 50: 217-224.

Hölscher D, Hertel D, Leuschner C, Hottkowitz M. 2002. Tree species diversity and soil patchiness in a temperate broad-leaved forest with limited rooting space. Flora 197: 118-125.

Holzapfel C, Alpert P. 2003. Root cooperation in a clonal plant: connected strawberries segregate roots. Oecologia 134: 72-77.

Hutchings MJ, John EA. 2004. The effects of environmental heterogeneity on root growth and root/shoot partitioning. Annals of Botany 94: 1-8. 
Jackson RB, Caldwell MM. 1993. The scale of nutrient heterogeneity around individual plants and its quantification with geostatistics. Ecology 74: 612-614.

Johnsen KH, Maier C, Kress L. 2005. Quantifying root lateral distribution and turnover using pine trees with a distinct stable carbon isotope signature. Functional Ecology 19: 81-87.

Kochenderfer JN. 1973. Root distribution under some forest types native to West-Virginia. Ecology 54: 445-448.

Korn S. 2004. Experimentelle Untersuchung der Wasseraufnahme und der hydraulischen Eigenschaften des Wurzelsystems von sechs heimischen Baumarten. PhD thesis. University of Göttingen, Germany.

Lambers JHR, Harpole WS, Tilman D, Knops J, Reich PB. 2004. Mechanisms responsible for the positive diversity-productivity relationship in Minnesota grasslands. Ecological Letters 7: 661-668.

Leuschner C. 1998. Mechanismen der Konkurrenzüberlegenheit der Rotbuche. Berichte der ReinhardTüxen-Gesellschaft 10: 5-18.

Leuschner C, Hertel D, Coners H, Büttner V. 2001. Root competition between beech and oak: a hypothesis. Oecologia 126: 276-284.

Leuschner C, Hertel D. 2003. Fine root biomass of temperate forests in relation to soil acidity and fertility, climate, age and species. Progress in Botany 64: 405-438.

Leuschner C, Hertel D, Schmid I, Koch O, Muhs A, Hölscher D. 2004. Stand fine root biomass and fine root morphology in old-growth beech forests as a function of precipitation and soil fertility. Plant and Soil 258: 43-56.

Li L, Sun JH, Zhang FS, Guo TW, Bao XG, Smith FA, Smith SE. 2006. Root distribution and interactions between intercropped species. Oecologia 147: 280-290.

Łomnicki A. 1980. Regulation of population-density due to individual-differences and patchy environment. Oikos 35: 185-193.

Ludwig F, Dawson TE, Prins HHT, Berendse F, de Kroon H. 2004. Below-ground competition between trees and grasses may overwhelm the facilitative effects of hydraulic lift. Ecological Letters 7: 623-631.

Lyford WH, Wilson BF. 1964. Development of the root system of Acer rubrum L. Harvard Forest Paper 10: 1-17.

Lyford WH, Wilson BF. 1966. Controlled growth of forest tree roots - technique and application. Harvard Forest Paper 16: 1-12.

Mahall BE, Callaway RM. 1991. Root communication among desert shrubs. Proceedings of the National Academy of Science 88: 874-876.

Majdi H. 1996. Root sampling methods - Applications and limitations of the minirhizotron technique. Plant and Soil 185: 255-258.

Mamolos AP, Elisseou GK, Veresodlou DS. 1995. Depth of root activity of coexisting grassland species in relation to $\mathrm{N}$ and $\mathrm{P}$ additions, measured using nonradioactive tracers. Journal of Ecology 83: 643-652.

McQueen DR. 1968. The quantitative distribution of absorbing roots of Pinus sylvestris and Fagus sylvatica in a forest succession. Acta Oecologia-Oecologia Plantarum 3: 83-89.

Morgan JL, Campbell JM, Malcolm DC. 1992. Nitrogen relations of mixed-species stands on oligotrophic soils. In: The ecology of mixed-species stands of trees. London, UK: Blackwell, 65-85.

Mou P, Jones RH, Mitchell RJ, Zutter B. 1995 Spatial-distribution of roots in sweetgum and Loblolly pine monocultures and relations with aboveground biomass and soil nutrients. Functional Ecology 9: 689-699.

Nagel J, Schmidt M. 2006. The silvicultural decision support system BWINPro. In: Hasenauer H. ed. Sustainable forest management, growth models for Europe. Berlin, Germany: Springer, 59-63.

Nambiar EKS, Sands R. 1993. Competition for water and nutrients in forests. Canadian Journal of Forest Research 23: 1955-1968.

Nielsen CCN, Mackenthun G. 1991. Die horizontale Variation der Feinwurzelintensität in Waldböden in Abhängigkeit von der Bestockungsdichte. Allgemeine Forst- und Jagdzeitung 162: 112-119. 
Nobel PS. 1997. Root distribution and seasonal production in the northwestern Sonoran desert for a C3 subshrub, a C4 bunchgrass, and a CAM leaf succulent. American Journal of Botany 84: 949-955.

Parrish JAD, Bazzaz FA. 1976. Underground niche separation in successional plants. Ecology 57: 1281-1288.

Rajaniemi TK. 2003. Evidence for size asymmetry of belowground competition. Basic and Applied Ecology 4: 239-247.

Rajaniemi TK, Allison VJ, Goldberg DE. 2003. Root competition can cause a decline in diversity with increased productivity. Journal of Ecology 91: 407-416.

Raynaud X, Leadley PW. 2005. Symmetry of belowground competition in a spatially explicit model of nutrient competition. Ecological Modelling 189: 447-453.

Robinson D, Hodge A, Griffiths BS, Fitter AH. 1999. Plant root proliferation in nitrogen-rich patches confers competitive advantage. Proceedings of the Royal Society of London - B 266: 431-435.

Roscher C, Temperton VM, Scherer-Lorenzen M, Schmitz M, Schumacher J, Schmid B, Buchmann N, Weisser WW, Schulze ED. 2005. Overyielding in experimental grassland communities - irrespective of species pool or spatial scale. Ecological Letters 8: 419-429.

Rust S, Savill PS. 2000. The root systems of Fraxinus excelsior and Fagus sylvatica and their competitive relationships. Forestry 73: 499-508.

Schenk HJ. 2006. Root competition: beyond resource depletion. Journal of Ecology 94: 725-739.

Schenk HJ, Callaway RM, Mahall BE. 1999. Spatial root segregation: Are plants territorial? Advances in Ecological Research 28: 146-180.

Scherer-Lorenzen M, Körner C, Schulze ED. 2005. Forest Diversity and Function. Berlin, Germany: Springer.

Schmid I. 2002. The influence of soil type and interspecific competition on the fine root system of Norway spruce and European beech. Basic and Applied Ecology 3: 339-346.

Schmid I, Kazda M. 2002. Root distribution of Norway spruce in monospecific and mixed stands on different soils. Forest Ecology and Management 159: 37-47.

Schwinning S. 1996. Decomposition analysis of competitive symmetry and size structure dynamics. Annals of Botany 77: 47-57.

Schwinning S, Weiner J. 1998. Mechanisms determining the degree of size asymmetry in competition among plants. Oecologia 113: 447-455.

Smit AL, Groenwold J, Vos J. 1994. The Wageningen Rhizolab - A facility to study soil-root-shootatmosphere interactions in crops. 2. Methods of root observations. Plant and Soil 161: 289-298.

Stout BB. 1956. Studies of the root system of deciduous trees. Black Rock Forest Bulletin 15: 1-45.

Thomas SC, Weiner J. 1989. Including competitive asymmetry in measures of local interference in plant populations. Oecologia 80: 349-355.

Tierney GL, Fahey TJ. 2001. Evaluating minirhizotron estimates of fine root longevity and production in the forest floor of a temperate broadleaf forest. Plant and Soil 229: 167-176.

Tilman D, Reich PB, Knops J, Wedin D, Mielke T, Lehman C. 2001. Diversity and productivity in a long-term grassland experiment. Science 294: 843-845.

Van Lear DH, Kapeluck PR. 1995. Above- and below-stump biomass and nutrient content of a mature Loblolly pine plantation. Canadian Journal of Forest Research 25: 361-367.

Van Praag HJ, Sougnezremy S, Weissen F, Carletti G. 1988. Root turnover in a beech and a spruce stand of the Belgian Ardennes. Plant and Soil 105: 87-103.

von Wettberg EJ, Weiner J. 2003. Larger Triticum aestivum plants do not preempt nutrient-rich patches in a glasshouse experiment. Plant Ecology 169: 85-92.

Weiner J, Wright DB, Castro S. 1997. Symmetry of below-ground competition between Kochia scoparia individuals. Oikos 79: 85-91.

Wilson JB. 1988. Shoot competition and root competition. Journal of Applied Ecology 25: 279-296. 
Yang Y, Chen G, He Z, Chen Y, Guo J. 2002. Production, distribution and nutrient return of fine roots in a mixed and a pure forest in subtropical China. Chinese Journal of Applied Environmental Biology 8: $223-233$.

Yokozawa M, Kubota Y, Hara T. 1998. Effects of competition mode on spatial pattern dynamics in plant communities. Ecological Modelling 106: 1-16. 


\section{Chapter 5}

\section{DOES ROOT COMPETITION ASYMMETRY INCREASE}

WITH WATER AVAILABILITY?

Boris Rewald and Christoph Leuschner 


\subsection{ABSTRACT}

Competition as a major structuring force in plant communities can be either symmetric or asymmetric with important consequences for the coexistence of plants in species assemblages. There is a vital debate as to whether belowground competition is symmetric or is similarly asymmetric as aboveground competition. Experimental evidence for asymmetric root competition is still scarce, in particular in communities of long-lived woody plants. Moreover, it is a matter of controversy if asymmetry in competition increases with resource availability or not.

We applied the in situ-root growth chamber approach to investigate the outcome of root competition between adult trees in a mixed beech-oak forest by altering the competitive neighbourhoods of fine roots and water availability experimentally. We tested the hypotheses that root competition between beech and oak is asymmetric and that asymmetry depends on soil moisture. Intact branch fine roots of beech and oak were allowed to grow for 365-390 d in root growth chambers while they were exposed to competition by either a conspecific (single-species chambers) or an allospecific root (two-species chambers). Species differences in relative root growth rate and fine root surface area increment were used to determine asymmetry in root competition. Different soil moisture regimes were considered by conducting a throughfall reduction experiment and by including data from earlier root competition experiments in beech-oak stands with contrasting soil water regimes.

Our results show that (i) the competitive interaction between beech and oak fine roots is clearly asymmetric, (ii) root morphology seems to depend on the competitor present, and (iii) the degree of asymmetry in root competition varies with soil moisture. We conclude that belowground competition in temperate broad-leaved mixed forests can be as asymmetric as is competition for light with asymmetry decreasing with increasing water shortage. 


\subsection{INTRODUCTION}

In the past, experimental and observational studies have provided much evidence that competition is a major structuring force in most terrestrial plant communities (Schoener 1983). Competition is an active process whose outcome is dependent on the relative abilities of the species to obtain resources such as light (Donald 1958), water (Moore 1929, Riegel et al. 1995, Seabloom et al. 2003) or nitrogen (Bartelheimer et al. 2006, Fargione and Tilman 2006). Although competition for light has been considered for long to be decisive for the performance of plants, nowadays there is growing evidence that root competition can have an influence as great as aboveground competition or even greater (Wilson 1988, Coomes and Grubb 2000, Kajimoto et al. 2007).

A variety of interaction processes in and between root systems have been identified which seem to be important in structuring the coexistence of root systems in the presence of intensive competition for soil resources. Chemical interference through allelopathy, so far unknown recognition systems, and indirect root interactions involving soil microorganisms and fauna may play an important role in the interaction between tree root systems (Mahall and Callaway 1991, Bonkowski et al. 2000, Schenk 2006). Presumably for improving resource use efficiency, roots have been found to avoid competition with roots of the same plant (Holzapfel and Alpert 2003, Gruntman and Novoplansky 2004, Falik et al. 2005). Under variable soil conditions, highly plastic responses of the root system's structure and of root morphology have been observed which may lead to an increased environmental tolerance and should affect uptake efficiency (Bradshaw 1965, Hodge 2006). Absorption rates of water and nutrients may change with specific root area, the number of root tips or the degree or type of mycorrhization (Gebauer and Stadler 1990, Taylor and Peterson 2005, Fargione and Tilman 2006).

There is a vital debate on the influence of resource availability on root competition. Two contrasting hypotheses have been formulated: (i) belowground competitive intensity is different in infertile and fertile, and in dry and moist soils (Grime 1979, Huston 1979, Keddy 1989, Wilson and Tilman 1993), or (ii) competition intensity is independent of water and nutrient availability (Newman 1973, Welden et al. 1988, Peltzer et al. 1998). Belowground and aboveground competition are fundamentally different with respect to the nature of the resources plants are competing for. In contrast to above- 
ground competition, where larger individuals can obviously pre-empt light at the expense of smaller plants and symmetric competition is the exception, belowground competition has been found to be either size-symmetric (Weiner et al. 1997, Cahill and Casper 2000) or asymmetric (Fransen et al. 2001, Rajaniemi 2003, Rewald and Leuschner 2008). It has been suggested that the picture of symmetric competition belowground may not be valid in patchy soils (Jackson and Caldwell 1993, Schwinning and Weiner 1998), and if uptake kinetics differ between competing plant species (Aerts and Chapin 2000). In any case, experimental evidence for asymmetric belowground competition is still scarce (Blair 2001, Rajaniemi 2003, von Wettberg and Weiner 2003). Although there is a long record of research on competition for water in crop plantations and forest stands (Korstian and Coile 1938, Welbank 1961, Zegada-Lizarazu et al. 2006), little research has focused on the question how root competition is affected by changes in water availability in forests. This topic is gaining importance because climate change may lead to a higher drought frequency in certain regions of the temperate zone (Weltzin et al. 2003, IPCC 2007). In the past, belowground interactions among woody plants have mostly been studied in agroforestry systems (Nambiar and Sands 1993, Akinnifesi et al. 1999, Moreno et al. 2005) or between adult trees and tree seedlings (Coomes and Grubb 2000, Barberis and Tanner 2005, Powell and Borg 2006). Studies on root competition between adult trees in mixed forests are virtually lacking. This is partly a consequence of difficult access to the root systems of mature trees. Moreover, root competition has to be analysed by experimental approaches in order to distinguish between symmetric and asymmetric competition, which is difficult to achieve. Recently, Hertel and Leuschner (2006) introduced the in situ-root growth chamber technique, which allows for the monitoring of fine root growth of mature trees in the soil while altering competitive neighbourhoods and resource availability experimentally.

Here, we present the results of a comprehensive in situ-root growth chamber study in a temperate Fagus-Quercus mixed forest, which investigated the relative growth rate of fine roots in different competitive neighbourhoods while soil moisture was experimentally altered. The aims of the study were (i) to test whether belowground competition in this mature forest is symmetric or asymmetric, (ii) to compare the influence of reduced soil moisture and/or interspecific competition on root morphology, and (iii) to analyse whether the degree of root competition asymmetry changes with soil moisture availability. 


\subsection{METHODS}

Study site

The study was carried out during 2005 and 2006 in a mixed forest consisting of 120 year-old Fagus sylvatica L. (European beech) and 200 year-old Quercus petraea (Matt.) Liebl. (Sessile oak) trees close to the village of Unterlüß (Lower Saxony, Germany, $52^{\circ} 14^{\prime} 50 \mathrm{~N}, 10^{\circ} 13^{\prime} 00 \mathrm{E}$; see Fig. A 4). Average stem density of mature trees was $220 \mathrm{ha}^{-1}$; maximum tree height was $30 \mathrm{~m}$ (Table 5.1). Situated in the diluvial lowlands of NW Germany (115 m a.s.1.), this site is characterized by acidic soil profiles (spododystric cambisols) with thick organic layers (mean depth of the entire organic profile is $7.2 \mathrm{~cm})$.

Table 5.1 Structural characteristics of the forest stands in Unterlüß and Ziegelroda.

\begin{tabular}{|c|c|c|c|c|c|}
\hline & $\begin{array}{l}\text { Age of dominant } \\
\text { trees [yrs] }\end{array}$ & $\begin{array}{c}\text { Stem } \\
\text { density } \\
{\left[\mathrm{ha}^{-1}\right]}\end{array}$ & $\begin{array}{l}\text { Tree height } \\
\text { [m] }\end{array}$ & $\begin{array}{c}\text { Stem basal } \\
\underset{\text { area }}{\left[\mathbf{m}^{2} \mathbf{h a}^{-1}\right]}\end{array}$ & $\underset{\left[\mathbf{m}^{2} \mathbf{m}^{-2}\right]}{\mathbf{L A I}}$ \\
\hline \multicolumn{6}{|c|}{ Unterlüß forest ${ }^{\mathrm{a}}$} \\
\hline Fagus & 120 & 176 & 30 & 15.2 & 3.3 \\
\hline Quercus & 200 & 44 & 28 & 12.3 & 1.6 \\
\hline Stand total & - & 220 & - & 27.5 & 4.9 \\
\hline \multicolumn{6}{|c|}{ Ziegelrodaer forest $^{\mathrm{b}}$} \\
\hline Fagus & 125 & 36 & 30 & 6.6 & 2.3 \\
\hline Quercus & 125 & 140 & 28 & 18.3 & 3.3 \\
\hline Carpinus & $70-90$ & 166 & 19 & 8.6 & 1.7 \\
\hline Tilia & $70-90$ & 10 & 26 & 1.3 & 0.5 \\
\hline Stand total & - & 352 & - & 34.8 & 7.8 \\
\hline
\end{tabular}

The climate is humid sub-oceanic (annual mean temperature: $8.1^{\circ} \mathrm{C}$, average annual rainfall: $801 \mathrm{~mm}$ ). The cumulative precipitation during the experimental period (May 2005 till the end of April 2006) was $818 \mathrm{~mm}$, which is close to the long-term mean precipitation (DWD 2006). The root studies were conducted in patches on the forest floor, which were situated halfway between Fagus and Quercus stems with overlapping fine root systems. Two plots were chosen for study, which were comparable 
with respect to stem density, tree height, and dbh. The stands on the two plots had a closed canopy and showed no signs of soil disturbance by wild boar. One of the two plots was equipped with a sub-canopy roof $(8 \mathrm{~m} \times 2.5 \mathrm{~m}, 1.6 \mathrm{~m}$ in height) made of a timber frame construction covered with transparent PVC plates which allowed to reduce soil moisture in a sufficiently large area (reduced soil moisture treatment). The roof was closed for a period of 11 months (June 2005 - April 2006) which resulted in a soil moisture reduction in the densely rooted topsoil by $5-15 \mathrm{vol} \%$ in this period compared to the uncovered soil (Table 5.2). The second plot served as a control with ambient soil moisture.

Table 5.2 Volumetric soil moisture (vol\%) in the surface layer of the control and reduced soil moisture plots of the Unterlüß stand between May 2005 and April 2006. Monthly means ( \pm SE) of six TDR measurements at two locations per plot are given.

\begin{tabular}{llcc}
\hline Year & Month & Control & Reduced soil moisture \\
\hline 2005 & May & $26.5 \pm 0.6$ & $27.7 \pm 0.9$ \\
& June & $25.5 \pm 0.5$ & $24.0 \pm 0.6$ \\
& July & $23.6 \pm 0.4$ & $14.5 \pm 1.1$ \\
& August & $19.5 \pm 0.3$ & $12.4 \pm 0.4$ \\
& September & $15.6 \pm 0.6$ & $10.8 \pm 0.2$ \\
& October & $22.5 \pm 0.5$ & $15.5 \pm 1.0$ \\
& November & $24.6 \pm 0.4$ & $15.5 \pm 0.4$ \\
& March & $32.2 \pm 0.3$ & $17.8 \pm 0.4$ \\
& April & $29.6 \pm 0.7$ & $16.8 \pm 0.5$ \\
\hline
\end{tabular}

\section{Root chamber experiment}

Hertel and Leuschner (2006) introduced the in situ-root growth chamber technique for monitoring fine root growth of trees in the soil of mature forests. This approach allows replicated experiments with branch fine roots of mature trees in forest soils by manipulating the fine root neighbourhood and thereby simulating different competitive situations among tree roots of two species. We applied this technique for quantifying the competitive ability of fine roots of Fagus and Quercus growing in mixture (interspecific competition) and compared the results with the outcome of intraspecific competition treatments. We used 180 root growth chambers that were manufactured from opaque PVC plates with a volume of $189 \mathrm{~cm}^{3}(9 \times 7 \times 3 \mathrm{~cm}$ length, height and width; see Fig. A 3). The chamber's front and back sides were perforated with holes, and the 
top and bottom consisted of plastic gauze to permit sufficient water percolation and gas exchange between the chambers and the surrounding soil. Two terminal branch fine roots were carefully excavated in the uppermost soil layers and inserted through small holes into opposite side walls. The chambers were filled with homogenized and rootfree mineral soil extracted in direct vicinity to the experimental plots. The chambers were then covered by a layer of soil and litter material and exposed for 365-390 days in the topsoil. At the point of insertion, the roots selected for study had a diameter of approx. $1 \mathrm{~mm} ; 2-3 \mathrm{~cm}$ of the terminal root section was enclosed into the chamber. The species identity of the roots was detected in situ from periderm morphology and colour as described by Hertel (1999). With the root growth chamber experiment we tested three different types of root interactions: two interspecific (two Fagus roots, treatment A, or two Quercus roots, treatment B), and one interspecific setting (one Fagus root and one Quercus root, treatment C). These three treatments were conducted in both the control plot with ambient soil moisture and in the reduced soil moisture plot, yielding six treatments in total. The root growth chambers were inserted in the roofed plot and in the control plot at locations were fine roots of beech or oak, or both species had been traced in the forest floor. Soil water content was measured monthly (except for periods with snow or ground frost) with a mobile time domain reflectometry probe (Trime FM2, Imko, Ettlingen, Germany). On each occasion, two measuring locations per plot were chosen by random and each three TDR measurements were conducted in an area of $50 \mathrm{~cm}$ in diameter (Table 5.2). Temperature measurement under the roof (iButton DS1921, Maxim, Sunnyvale, USA) showed that the shelter resulted in an only small reduction of the soil temperature in the rooting horizon during summer (by $0.5-1.0 \mathrm{~K}$ in $7 \mathrm{~cm}$ depth) as compared to the uncovered plot (data not shown).

We attempted to accommodate each of the six studied interaction types with about 30 root chambers to allow for statistical analysis of the data. At the time of harvest, the branch roots were cut at the insertion holes and carefully extracted from the chamber. For investigating root morphology, all roots were analysed for specific fine root surface area (SRA, $\mathrm{cm}^{2} \mathrm{~g} \mathrm{~d} . \mathrm{wt}^{-1}$ ) using a flat bed scanner and the image analysis program WinRhizo 2005b (Régent Instruments, Québec, Canada). Subsequently, root dry mass $\left(48 \mathrm{~h}, 70^{\circ} \mathrm{C}\right)$ was determined in the laboratory. Root performance was assessed as relative growth rate $\left(\mathrm{RGR}, \mathrm{mg} \mathrm{g}^{-1} \mathrm{~d}^{-1}\right)$ between insertion date and day of harvest. The initial biomass of the two inserted fine roots was estimated non-destructively by photographing the roots in front of a graph paper at the beginning of the experiment and calculating 
the initial tissue volume with WinRhizo. The initial dry mass of the root endings was estimated from root dry mass/volume relationships that were established for the two tree species. Since root surface area is a better estimator of resource uptake capacity than root mass, we determined root surface area increment (RSAI, $\mathrm{m}^{2} \mathrm{~m}^{-3} \mathrm{~d}^{-1}$ ) from the RGR and SRA data. We were not able to reach a fully balanced experimental design in the root chamber study because root species identification in the field was erroneous in some cases. Furthermore, approx. $20 \%$ of the chambers were disturbed by the ingrowth of additional fine roots from the surrounding soil, and thus had to be abandoned.

For quantifying a species' ability to compete successfully with the roots of other tree species for soil space and resources, we calculated a relative competitive ability index (CA), which uses fine root RGR as a belowground fitness parameter (Goldberg and Scheiner 1993, Wilson and Tilman 1993). We assumed that root growth is closely linked to an increase in absorbing surface area and thus to a growing nutrient and water absorption capacity of the fine root system (Grace 1995). A species' RGR in interspecific interaction (two-species chambers, treatment $\mathrm{C}, \mathrm{RGR}_{\text {mix }}$ ) was contrasted with its RGR in intraspecific interaction (single-species chambers, treatment $\mathrm{A}$ and $\mathrm{B}, \mathrm{RGR}_{\text {mono }}$ ) with

$\mathrm{CA}=\left(\mathrm{RGR}_{\text {mix }}-\mathrm{RGR}_{\text {mono }}\right) \times \mathrm{RGR}_{\text {mono }}{ }^{-1}$

By definition, a species has a positive CA value if, on average, it grows better with a root of the other species than with a conspecific root. Negative values indicate better growth with a conspecific than with an allospecific root. Our definition of the CA index resembles the 'relative competition intensity index' (RCI) as formulated by Grace (1995), which also compares plant performance in mixture with that in monoculture. However, in contrast to Grace (1995), we do not interpret a better growth in mixture as higher competition intensity in the community, but rather as evidence of competitive superiority in comparison to a second species, i.e. as competitive ability of the target plant or species in a two-species interaction. In fact, competition intensity may be equally high, or even higher, in monocultures compared to mixtures (Stoll and Prati 2001). The differences between the competitive abilities of Fagus and Quercus roots $(\triangle \mathrm{CA})$, growing in mixture, were used to assess competitive asymmetry. On the other hand, identical CA values in a given interaction would imply full symmetry in the out- 
come of root interaction. In the present study, competition experiments were conducted under two contrasting soil moisture conditions (control treatment with moist soil, and reduced soil moisture treatment). In order to cover a broader range of soil moisture conditions, additional data on CA of Fagus and Quercus roots obtained in two earlier root competition experiments were included in the analysis as well. Hertel (1999) conducted an experiment in the same stand at Unterlüß in two periods with high and moderate rainfall. The second root competition experiment took place in a 100 year-old mixed Fagus-Quercus-Carpinus-Tilia forest at Ziegelroda, Saxony-Anhalt, Central Germany (Rewald and Leuschner 2008; Fig. A 6). Both stands contain patches with mature, 28-30 m tall Fagus and Quercus trees in close proximity to each other, which were selected for exposing the root growth chambers. However, the Ziegelrodaer forest experienced greater soil water deficits in summer than the Unterlüß forest (mean annual precipitation 801 vs. $520 \mathrm{~mm}$ ). By combining the data from the two hydrological contrasting stands with the results of the throughfall exclusion experiment in 2005/2006, we were able to assemble the results of five Fagus/Quercus root competition experiments which differed with respect to soil moisture availability. For all five experiments, we calculated the cumulative soil water deficit for the period June 1 to October 31 based on volumetric soil moisture data of this study (Unterlüß forest) or from Burk (2006, Ziegelrodaer forest). The difference between monthly mean soil water content and water content at field capacity ( soil matric potential $=100 \mathrm{hPa}$ ) was added for the five months to obtain a cumulative deficit for the vegetation period. The $\triangle \mathrm{CA}$ values of the five experiments were plotted against the cumulative soil water deficit.

\section{Statistical analysis}

All data sets were tested for Gaussian distribution with a Shapiro-Wilk test. We used a parametric Scheffé's multiple comparison procedure to test for significant differences in SRA between the different competition and soil moisture treatments. A non-parametric Mann-Whitney $U$ test was used to detect if the tree species had a different RGR, and differed with respect to root surface area increment (RSAI) and competitive ability (CA). Calculations were conducted with SAS version 8.02 (SAS Institute, Cary, USA). Linear regressions were calculated with the program Xact 8.03 (SciLab, Hamburg, Germany). 


\subsection{RESULTS}

\section{Relative root growth rates in intra- and interspecific environments}

In the in situ-root growth chamber experiment in the Unterlüß forest, Quercus roots showed the highest relative growth rate (RGR) when exposed with Fagus roots at ambient moisture conditions (Control: treatment C, Fig. 5.1). In contrast, the RGR of Quercus roots was significantly lower when growing together with a conspecific root (treatment B). In the single species chambers with ambient soil moisture (Control: treatment A and B), Fagus fine roots had a slightly higher RGR than Quercus roots (difference not significant). Moreover, Fagus roots grew not significantly better with allospecific than with a conspecific competitor, which contrasts with the behaviour of Quercus roots in the control treatment.

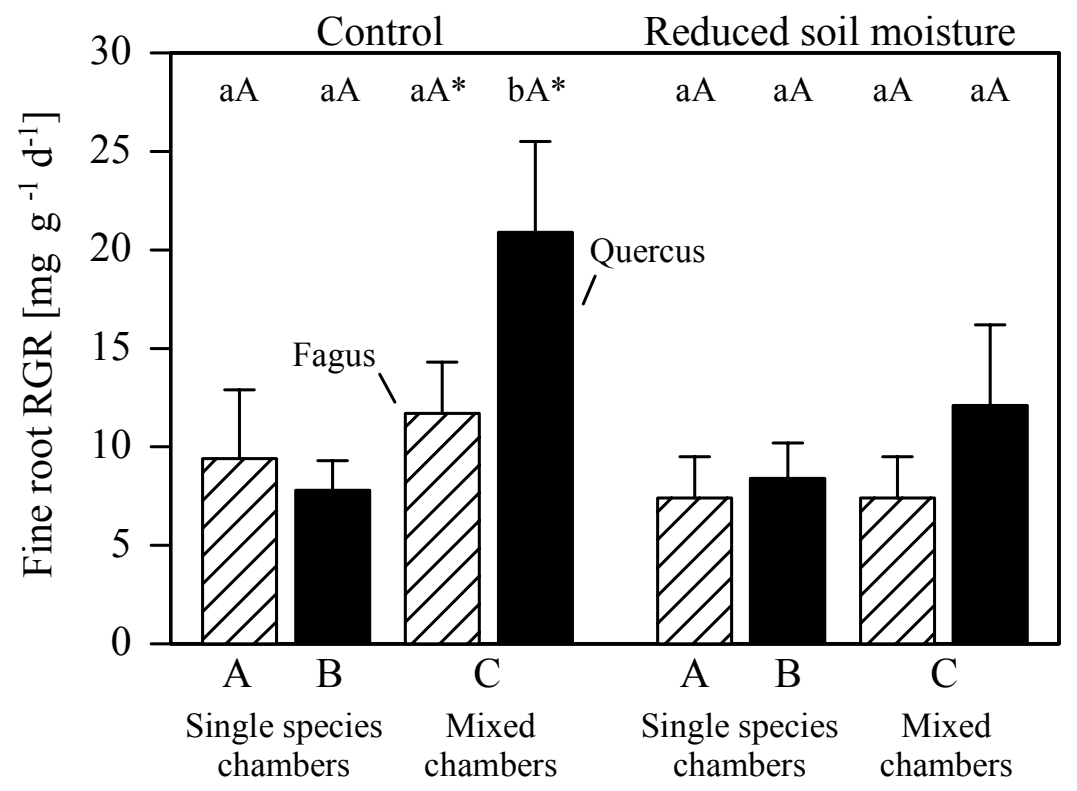

Fig. 5.1 Relative growth rate of Fagus and Quercus fine roots when being exposed for 365-390 d in in situ-root growth chambers in the field under different neighbourhoods (single species chambers: treatments A and B vs. two-species chambers: C) and soil moisture regimes (control vs. reduced soil moisture). Single species chambers contained two branch fine roots of the same species (Fagus or Quercus), mixed chambers each one Fagus and one Quercus root. The volumetric soil moisture was lowered by the roof in the reduced soil moisture plot by about $5-15 \mathrm{vol} \%$ compared to the control plot. Significant species-specific differences in root RGR within each moisture treatment are indicated by different lower case letters, significant differences between moisture treatments are indicated by capitals, and significant differences between species are marked by asterisks (Mann-Whitney $U$ test, $\mathrm{p}<0.05$, mean+SE, $n=23-46$ ). 
In fact, RGR of Quercus in mixture was significantly higher than that of Fagus. Under experimentally reduced soil moisture, lower RGR values and no significant differences between intra- and interspecific treatments were found. The competitive ability index (CA), which is defined as fine root RGR of the target species in intraspecific interaction as compared to growth in interspecific interaction, showed significant differences between the species and soil moisture treatments. Both species shared small CA values $(<0.5)$ in the reduced soil moisture treatment in mixture, which indicates that the difference in the performance of the two species was small under water shortage. Moreover, our data shows that Fagus and Quercus roots behaved much more similar in the reduced soil moisture treatment than in the control treatment where the CA values revealed a larger difference (Table 5.3). Thus, $\triangle \mathrm{CA}$ increased from the reduced soil moisture treatment to the control. By adding three more data points on $\triangle \mathrm{CA}$ of similar root competition experiments conducted by Hertel (1999) and Rewald and Leuschner (2008) in the Unterlüß and Ziegelrodaer forests, a significant negative relationship between soil moisture deficit and $\Delta \mathrm{CA}$ of Fagus and Quercus roots appeared (Fig. 5.2).

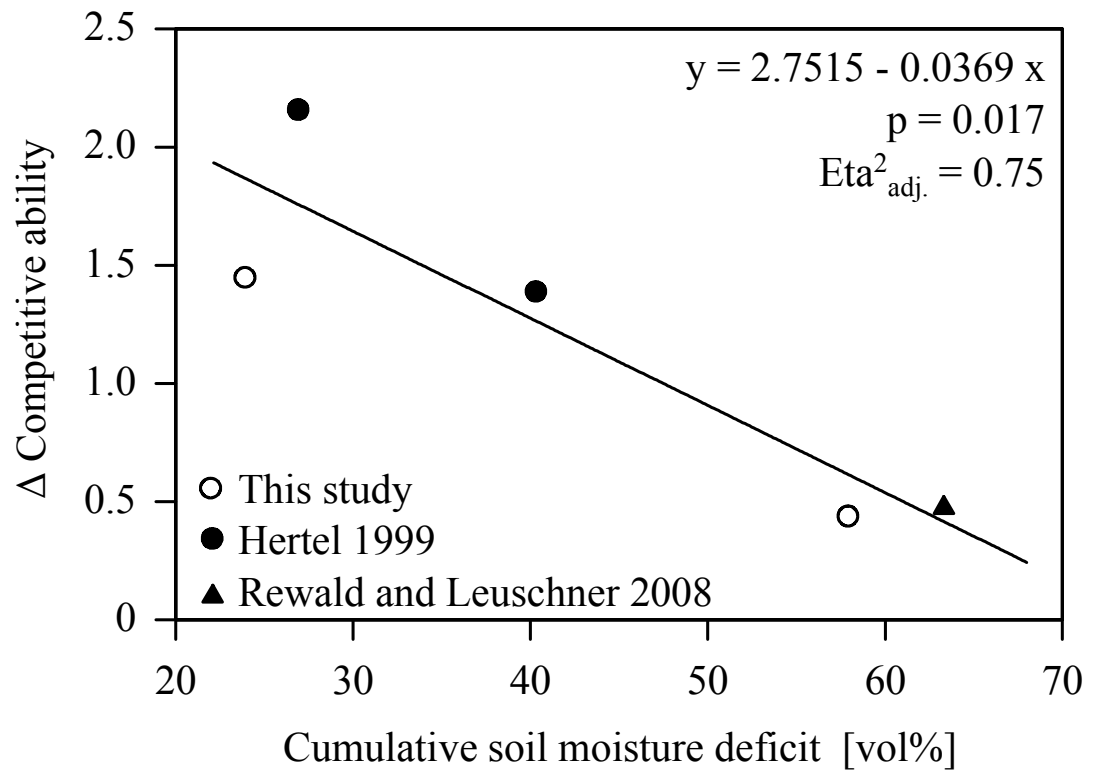

Fig. 5.2 Difference between the competitive ability ( $\Delta \mathrm{CA})$ of Fagus and Quercus fine roots in interspecific competition as dependent on the cumulative soil moisture deficit in the period June to October (vol\%). The accumulated soil moisture deficit was calculated as the sum of differences between monthly mean soil water content and water content at field capacity. In addition to the results from the present study (reduced soil moisture and control plots), we added data from other experiments conducted with Fagus and Quercus roots in in situ-root growth chambers (Hertel 1999, Rewald and Leuschner 2008). A competitive ability of zero stands for symmetric root competition, values above zero for superior growth either of Fagus or of Quercus roots in comparison to their competitor. The larger the $\Delta \mathrm{CA}$ value, the more asymmetric was the outcome of the interaction. 


\section{Fine root morphology and root surface area increment}

The highest mean SRA values of Fagus $\left(367 \pm 17 \mathrm{~cm}^{2} \mathrm{~g}^{-1}\right)$ and Quercus $\left(406 \pm 17 \mathrm{~cm}^{2} \mathrm{~g}^{-1}\right)$ occurred in the control treatment with ample soil moisture (Table 5.3). In this treatment, SRA of Fagus increased significantly under interspecific competition; in contrast, the SRA of Quercus roots was lower when exposed to allospecific roots. In the reduced soil moisture treatment, specific root area was either reduced or reached similar values as in the control. By calculating root surface area increment (RSAI) for the roots in the experiments, mass-related root growth rates were linked to root morphology (Table 5.3). In the control treatment with interspecific competition, both species showed highest RSAI rates. RSAI was significantly lower in the reduced soil moisture treatment. This difference was particularly large in the root chambers with interspecific competition.

Table 5.3 Specific root area (SRA), root surface area increment (RSAI) and competitive ability (CA) under different soil moisture treatments (control and reduced soil moisture) and competition treatments (single species chambers, treatments A and B: 'Mono', two-species chambers, treatment C: 'Mix'). Significant differences between the two competition treatments within a soil moisture treatment are indicated by different lower case letters, significant differences between soil moisture treatments by different capitals and significant differences between competitive treatments of the same moisture treatment by asterisks (SRA: Scheffé test, RAI and CA: Mann-Whitney U test, $\mathrm{p}<0.05$, mean $\pm \mathrm{SE}, n=$ number of replicates).

\begin{tabular}{|c|c|c|c|c|c|c|}
\hline $\begin{array}{l}\text { Target } \\
\text { species }\end{array}$ & $\begin{array}{l}\text { Soil mois- } \\
\text { ture treat- } \\
\text { ment }\end{array}$ & $\begin{array}{l}\text { Competi- } \\
\text { tion treat- } \\
\text { ment }\end{array}$ & $n$ & $\underset{\left[\mathrm{cm}^{2} \mathbf{g}^{-1}\right]}{\text { SRA }}$ & $\begin{array}{c}\text { RSAI } \\
{\left[10^{-3} \mathrm{~m}^{2} \mathrm{~m}^{-3} \mathrm{~d}^{-1}\right]}\end{array}$ & $\mathbf{C A}$ \\
\hline Fagus & Control & Mono (A) & 52 & $318 \pm 23$ aA & $4.4 \pm 0.8$ & - \\
\hline Quercus & Control & Mono (B) & 36 & $367 \pm 17$ aA & $4.9 \pm 1.2$ & - \\
\hline Fagus & Control & $\operatorname{Mix}(C)$ & 31 & $398 \pm 42$ aA* & $6.5 \pm 1.8$ & $0.24 \pm 0.44 \mathrm{aA}$ \\
\hline Quercus & Control & $\operatorname{Mix}(\mathrm{C})$ & 31 & $280 \pm 19$ bA* & $9.5 \pm 1.7 \quad b A^{*}$ & $1.69 \pm 0.60 \mathrm{bA}$ \\
\hline Fagus & Reduced & Mono (A) & 44 & $280 \pm 21 \quad \mathrm{aA}$ & $2.4 \pm 0.5$ & - \\
\hline Quercus & Reduced & Mono (B) & 32 & $289 \pm 16 \quad \mathrm{aB}$ & $2.9 \pm 0.5$ & - \\
\hline Fagus & Reduced & $\operatorname{Mix}(C)$ & 25 & $290 \pm 18 \quad a B$ & $1.7 \pm 0.4$ & $0.0001 \pm 0.29 \mathrm{aB}$ \\
\hline Quercus & Reduced & $\operatorname{Mix}(C)$ & 25 & $252 \pm 26$ aA & $3.4 \pm 0.6$ & $0.44 \pm 0.49 \mathrm{bB}$ \\
\hline
\end{tabular}




\subsection{DiscuSSION}

\section{Evidence of asymmetric competition belowground?}

Symmetry and asymmetry of competition have generally been defined by comparing the relationships between plant biomass and plant resource acquisition between the competing plants (usually measured as plant growth rate or nutrient uptake; Hara 1993, Grace 1995, Schwinning and Fox 1995). If the growth rates of competitors are in proportion to their initial plant biomass, competition is defined as being symmetric (Weiner 1990). Light, as a relatively unidirectional resource, may be pre-emptable by larger neighbours, leading to asymmetric competition, whereas water and mobile nutrients are generally thought to be less pre-emptable, resulting in more size-symmetric competition (Newbury and Newman 1978, Ford and Diggle 1981, Weiner 1986). However, it has recently been hypothesised that root competition may also be asymmetric (Schwinning 1996), while experimental results supporting this assumption are scarce and mostly refer to herbaceous plants (Blair 2001, Fransen et al. 2001, Facelli and Facelli 2002, Rajaniemi 2003, Rewald and Leuschner 2008). In contrast, the number of experiments suggesting symmetric competition belowground is much larger (Schwinning and Weiner 1998, Cahill and Casper 2000, von Wettberg and Weiner 2003). Our study provides evidence that the interaction between Fagus and Quercus roots in mature stands is asymmetric since the roots of the two species grew significantly different in two-species chambers, thus exhibiting different RGR and SRAI rates (Fig. 5.1, Table 5.3). This contrasts with the performance in single-species chambers, where Fagus and Quercus root growth was not different. Numerous earlier studies (Ross and Harper 1972, Elberse and de Kruyf 1979, Fowler 1984, Van Baalen et al. 1984) have demonstrated that an initial size advantage of one competitor can rapidly cause competitive inequality in any interaction. To avoid this shortcoming, we carefully selected equal-sized branch roots for the root growth chamber experiments to test for species-specific disproportionallity effects.

We thus can exclude that the contrasting root growth rates in chambers with inter- and intraspecific competition are a consequence of initial differences in root size of the species. Rather, other non-size-symmetric factors must be responsible. Unfortunately, our experiments do not allow conclusions on the underlying mechanisms of this asymmetric belowground interaction. A number of processes may possibly be involved. 
It has been suggested that asymmetric belowground competition may occur especially in patchy soil environments (Jackson and Caldwell 1993, Schwinning and Weiner 1998, Casper et al. 2000), where larger plants with a more extensive root system are able to occupy nutrient-rich soil patches over-proportionally (Van Lear and Kapeluck 1995) and pre-empt soil water and nutrient reserves before smaller plants can gain access (Robinson et al. 1999, Craine et al. 2005). Competitive ability seems to be closely related to the ability to rapidly fill a soil volume with roots (Rajaniemi 2007). Self-self-inhibition could also have occurred in the intraspecific treatments. Roots of the same species have been found to be self-inhibiting in certain herbaceous and shrubby species (Falik et al. 2003, 2005, Gruntman and Novoplansky 2004); this would lead to a lower growth rate in treatments with intra- compared to interspecific competition. Selfself-inhibition is thought to be favourable, because competition between roots of the same individual will lower resource use efficiency and thus may reduce plant fitness (Schenk 2006). Another mechanism that could have caused the observed nonproportionality in root growth are different water or nutrient uptake rates of the competing species (Eissenstat and Caldwell 1988b, Raynaud and Leadley 2005). It was been shown that nutrient uptake kinetics can differ between plant species under certain conditions of nutrient or soil water availability (Jackson and Caldwell 1991, 1996, Aerts and Chapin 2000, Raynaud and Leadley 2004, Wang and Cheng 2004).

Although the root growth chambers of this study were designed to simulate fine root growth in a soil environment as natural as possible, some artefacts are inherent to this method, e.g. an initial disturbance of the mycorrhizosphere and an artificially dense and homogeneous soil (Hertel and Leuschner 2006). The growth experiments may also be biased by species-specific temporal patterns of fine root growth (Eissenstat and Caldwell 1988a, Burke and Chambers 2003). However, the observed high degree of mycorrhizal infection of root tips and the long period of exposure ( $\geq 1 \mathrm{yr}$ ) indicate that these errors should have been less important. We believe that the in situ-ingrowth chamber technique is a promising experimental tool for analysing root interactions between mature trees with a statistically sound design. Other approaches for studying fine root growth in situ such as mini-rhizotrons are less suitable for investigating root competition of mature trees in forests (see Rewald and Leuschner 2008 for a detailed discussion).

Our experimental data on the outcome of root competition are support for more recent spatial modelling studies and theoretical analyses, which concluded that belowground 
competition in mature forests should be rather asymmetric than symmetric (Aikio 2004, Raynaud and Leadley 2005). Taken together, these results contradict assumptions on mechanisms and the outcome of root competition, which have been obtained with herbs and grassland species (Weiner 1986, Schwinning 1996, Cahill and Casper 2000, Herben et al. 2007). In any case, symmetric and asymmetric competition must be viewed as the extremes of a continuum. In fact, roots compete simultaneously for several resources and their interaction may be a combination of all relevant resource-capturing processes (Schwinning and Weiner 1998).

Is root biomass increment an adequate parameter for quantifying belowground competition?

A large number of biotic and abiotic factors, including soil moisture and nutrient availability as well as mycorrhizal fungi, bacteria and other soil organisms, are known to influence the formation of the morphological characteristics of fine roots (Fitter and Stickland 1991, Kozlowski et al. 1991). As resource supply changes, changes in fine root biomass allocation and phenotype may lead to increased environmental tolerance and resource uptake efficiency (Robinson et al. 1994, Chiatante et al. 2005, De Lillis et al. 2005, Poyatos et al. 2007), which is likely to influence competitive ability (Grime et al. 1991). In particular, absorption rates of water and nutrients may change with specific root area, the number of root tips or the degree of mycorrhization (Gebauer and Stadler 1990, Taylor and Peterson 2005, Fargione and Tilman 2006). We found significantly different specific root areas (SRA) in different competition and soil moisture treatments (Table 5.3). Quercus roots have a significantly smaller SRA when subjected to reduced soil moisture, indicating that very fine branch roots were only present at ambient soil moisture. Interestingly, the finest root diameters were also missing at ambient moisture when Quercus roots competed with Fagus roots. Thus, SRA was not only depending on soil moisture characteristics but apparently also on competitive neighbourhood. This would shed a new light on how root surface area is controlled by the biotic and abiotic environment of the root (Lõhmus et al. 1989, Ostonen et al. 1999). Plant morphology and architecture strongly determine how plants acquire and also deprive their neighbours of resources (Nye and Tinker 1977). Consequently, plant form has been found to influence the degree of competition symmetry (Geber 1989, Thomas and Weiner 1989, Hara 1993). We suggest that root surface area increment (RSAI) should be a more appropriate fitness parameter of competing roots than the mass-related 
root growth rate (RGR), because RSAI is more directly linked to the absorbing surface than is root mass. However, the choice of the fitness parameter influences the result of asymmetry assessments. The significantly smaller SRA of Quercus roots in interspecific competition under ambient soil moisture counteracted the larger biomass increment of this species and led to a more symmetric root surface area increment among the two species. This finding is in accordance with Schwinning and Weiner (1998) who suggested a similarly plastic response to neighbour-induced resource depletion as to environmental gradients. These authors have hypothesised that plasticity in morphology and physiology can act to reduce asymmetry in competition by reducing the differences in resource uptake. In contrast to aboveground properties (Ballaré et al. 1994, Umeki 1997), we know much less about the mechanisms that may lead to neighbour-induced plastic responses in root morphology and root system structure. They must primarily be adaptations to avoid, or at least reduce, competitive suppression (Schwinning and Weiner 1998).

Previous studies have focused primarily on observed size-related effects in the outcome of competition among plants. Our results show that we need to replace generalising parameters such as biomass increase or relative growth rate by variables that are more directly related to water and nutrient uptake by considering root morphology and physiology as well, which ultimately determine success in root competition.

Does the degree of belowground competitive asymmetry vary with soil resource availability?

There is an ongoing controversy as to whether competition intensity varies along environmental gradients (Huston 1979, Keddy 1989, Wilson and Tilman 1993, TowlanStrutt and Keddy 1996, Goldberg et al. 1999), or is independent from abiotic factors such as water and nutrient availability (Newman 1973, Tilman 1988, Welden et al. 1988, Peltzer et al. 1998). In this study, we conducted a below-canopy throughfall reduction experiment to investigate whether the degree of root competition asymmetry changes with soil water availability. Our results, complemented by related data of the studies by Hertel (1999) and Rewald and Leuschner (2008), provided evidence that the asymmetry of root growth or surface area increment between competing Fagus and Quercus roots decreased with increasing soil moisture deficit. This analysis, based on five different experiments, revealed a significant correlation between competitive asymmetry $(\triangle \mathrm{CA})$, expressed as difference between species-specific competitive abili- 
ties, and cumulative soil moisture deficit (Fig. 5.2). Thus, marked asymmetry in the outcome of root competition only developed when soil moisture in summer was sufficiently high. Resource limitation, i.e. drought, seems to hit both species in a similar manner with the consequence that species-specific differences in competitive ability in mixture are disappearing in the more stressful environment. Therefore, the overall importance of direct biotic interactions belowground seems to be reduced under limited soil water availability.

We are aware that competition experiments that differ in duration may create severe problems to any data analysis (Osenberg et al. 1999). Fortunately, all included studies of our meta-analysis of root competition experiments were running long-term ( $\geq 6$ months), covering at least one vegetation period. Our findings are consistent with previous studies which indicated that ample supply of belowground resources, especially sufficiently high precipitation, lead to a more pronounced asymmetry in aboveground growth among competing plants (Skovsgaard 1997, Wichmann 2001). Raynaud and Leadley (2005) suggested that the asymmetry of competition should increase with increasing nutrient and water supply because, under high soil moisture, ion diffusivity increases and uptake rate depends mostly on root physiology (Williams and Yanai 1996, Raynaud and Leadley 2004). The model of Raynaud and Leadley (2005) suggests that the diffusivity of the soil is a major determinant of the size-symmetry or asymmetry of root competition and that this interaction can vary from near size-symmetry under conditions of low diffusivity to size asymmetry with increasing diffusive supply.

To test this hypothesis, we used data on soil $\mathrm{pH}$ and cation exchange capacity (CEC) as rough measures of soil nutrient availability to investigate a possible soil fertility dependence of competition asymmetry in the five experiments. We did not find a dependence of the degree of asymmetry on $\mathrm{pH}$ or CEC (data not shown). This indicates that, in these experiments, water availability, rather than nutrient availability per se, was controlling competition asymmetry, probably because a low diffusivity as caused by low soil moisture overrules differences in nutrient concentrations or mineralisation rates in the soil. Competition for water should be size symmetric only if each unit of root surface has the same specific uptake rate (Schwinning and Weiner 1998). However, in situ measurements with miniaturized sap flow gauges have provided increasing evidence that different tree species, root size classes, and different roots of the same tree can differ by an order of magnitude in water uptake rate or even more despite access to the same soil volume (Korn 2004, Leuschner et al. 2004). Thus, it becomes clear that sim- 
ple models linking root biomass with competitive ability are most likely misleading in many forest ecosystems.

\subsection{CONCLUSION}

Our results show that (i) tree species competition belowground is clearly asymmetric in the studied stand, (ii) root morphology seems to depend on the competitor present, thereby modifying the degree of competitive asymmetry, and (iii) the degree of competitive asymmetry varies with soil moisture status. Asymmetry only develops in the absence of water shortage. Future experimental studies in the rhizosphere of forests have to reveal whether these findings apply to other resource gradients and species as well, and what mechanisms (including resource competition, self-self-inhibition, facilitation, allelopathy, or indirect competitive interactions through other organisms or agents) underlie the observed root growth responses in the chambers. 


\subsection{REFERENCES}

Aerts R, Chapin III FS. 2000. The mineral nutrition of wild plants revisited: A re-evaluation of processes and patterns. Advances in Ecological Research 30: 1-67.

Aikio S. 2004. Competitive asymmetry, foraging area size and coexistence of annuals. Oikos 104: 51-58.

Akinnifesi FK, Smucker AJM, Kang BT. 1999. Below-ground dynamics in agroforestry systems. Annals of Arid Zone 38: 239-273.

Ballaré CL, Scopel AL, Jordan ET, Vierstra RD. 1994. Signalling among neighboring plants and the development of size inequalities in plant-populations. Proceedings of the National Academy of Science 91: 10094-10098.

Barberis IM, Tanner EVJ. 2005. Gaps and root trenching increase tree seedling growth in Panamanian semi-evergreen forest. Ecology 86: 667-674.

Blair B. 2001. Effect of soil nutrient heterogeneity on the symmetry of belowground competition. Plant Ecology 156: 199-203.

Bonkowski M, Cheng WX, Griffiths BS, Alphei G, Scheu S. 2000. Microbial-faunal interactions in the rhizosphere and effects on plant growth. European Journal of Soil Biology 36: 135-147.

Bradshaw AD. 1965. Evolutionary significance of phenotypic plasticity in plants. Advances in Genetics 13: $115-155$.

Burk D. 2006. Physiological, anatomical and chemical factors controlling water uptake by beech, pine and birch roots in two forests differing in water supply (In German). PhD thesis. University of Göttingen, Germany.

Burke MK, Chambers J. 2003. Root dynamics in bottomland hardwood forests of the southeastern United States coastal plain. Plant and Soil 250: 141-153.

Cahill JF, Casper BB. 2000. Investigating the relationship between neighbor root biomass and belowground competition: Field evidence for symmetric competition belowground. Oikos 90: 311-320.

Casper BB, Cahill JF, Jackson RB. 2000. Plant competition in spatial heterogeneous environments. In: Hutchings MJ, John EA, Stewart AJA. eds. Ecological consequences of habitat heterogeneity. Oxford, UK: Blackwell, 111-130.

Chiatante D, Di Iorio A, Scippa GS. 2005. Root responses of Quercus ilex L. seedlings to drought and fire. Plant Biosystems 139: 198-208.

Connell JH. 1983. On the prevalence and relative importance of interspecific competition - Evidence from field experiments. American Naturalist 122: 661-696.

Coomes DA, Grubb PJ. 2000. Impacts of root competition in forests and woodlands: A theoretical framework and review of experiments. Ecological Monographs 70: 171-207.

Craine JM, Fargione J, Sugita S. 2005. Supply pre-emption, not concentration reduction, is the mechanism of competition for nutrients. New Phytologist 166: 933-940.

De Lillis M, Manes F, Tufaro F. 2005. Root plasticity in Mediterranean herbaceous species. Plant Biosystems 139: 214-221.

Donald CM. 1958. The interaction of competition for light and for nutrients. Australian Journal of Agricultural Research 9: 421-435.

DWD 2006. Monatliche Witterungsberichte 2005-2006. Witterungsreport "Express" des Deutschen Wetterdienstes. Offenbach, Germany.

Eissenstat DM, Caldwell MM. 1988a. Seasonal timing of root-growth in favorable microsites. Ecology 69: $870-873$.

Eissenstat DM, Caldwell MM. 1988b. Competitive ability is linked to rates of water extraction - A fieldstudy of 2 aridland tussock grasses. Oecologia 75: 1-7. 
Elberse WTH, de Kruyf HN. 1979. Competition between Hordeum vulgaris L. and Chenopodium album L. with different dates of emergence of Chenopodium album L. Netherlands Journal of Agricultural Science 27: 13-26.

Facelli E, Facelli JM. 2002. Soil phosphorus heterogeneity and mycorrhizal symbiosis regulate plant intra-specific competition and size distribution. Oecologia 133: 54-61.

Falik O, Reides P, Gersani M, Novoplansky A. 2003. Self/non-self discrimination in roots. Journal of Ecology 91: 525-531.

Falik O, Reides P, Gersani M, Novoplansky A. 2005. Root navigation by self inhibition. Plant, Cell and Environment 28: 562-569.

Fargione J, Tilman D. 2006. Plant species traits and capacity for resource reduction predict yield and abundance under competition in nitrogen-limited grassland. Functional Ecology 20: 533-540.

Fitter AH, Stickland TR. 1991. Architectural analysis of plant-root systems. 2. Influence of nutrient supply on architecture in contrasting plant-species. New Phytologist 118: 383-389.

Ford ED, Diggle PJ. 1981. Competition for light in a plant monoculture modelled as a spatial stochasticprocess. Annals of Botany 48: 481-500.

Fowler NL. 1984. The role of germination date, spatial arrangement, and neighborhood effects in competitive interactions in Linum. Journal of Ecology 72: 307-318.

Fransen B, de Kroon H, Berendse F. 2001. Soil nutrient heterogeneity alters competition between two perennial grass species. Ecology 82: 2534-2546.

Gebauer G, Stadler J. 1990. Nitrate assimilation and nitrate content in different organs of ash trees (Fraxinus excelsior). In: van Beusichem ML. ed. Plant nutrition - Physiology and applications. Dortrecht, The Netherlands: Kluwer, 101-106.

Geber MA. 1989. Interplay of morphology and development on size inequality: A Polygonum greenhouse study. Ecological Monographs 59: 267-288.

Goldberg DE, Barton AM. 1992. Patterns and consequences of interspecific competition in natural communities - A review of field experiments with plants. American Naturalist 139: 771-801.

Goldberg DE, Scheiner SM. 1993. ANOVA and ANCOVA: field competition experiments. In: Scheiner SM, Gurevitch J. eds. Design and analysis of ecological experiments. London, UK: Chapman and Hall, 69-93.

Goldberg DE, Rajaniemi TK, Gurevitch J, Stewart-Oaten A. 1999. Empirical approaches to quantifying interaction intensity: Competition and facilitation along productivity gradients. Ecology 80: 1118-1131.

Grace JB. 1995. On the measurement of plant competition intensity. Ecology 76: 305-308.

Grime JP. 1979. Plant strategies and vegetation processes. Chichester, UK: Wiley.

Grime JP, Campbell BD, Mackey JML, Crick JC. 1991. Root plasticity, nitrogen capture and competitive ability. In: Atkinson D. ed. Plant root growth. An ecological perspective. London, UK: Blackwell, 381-397.

Gruntman M, Novoplansky A. 2004. Physiologically mediated self/non-self discrimination in roots. PNAS 101: 3863-3867.

Hara T. 1993. Effects of variation in individual growth on plant-species coexistence. Journal of Vegetation Science 4: 409-416.

Herben T, Biezina S, Skalova H, Hadincova V, Krahulec F. 2007. Variation in plant performance in a grassland: Species-specific and neighbouring root mass effects. Journal of Vegetation Science 18: 55-62.

Hertel D. 1999. Das Feinwurzelsystem von Rein- und Mischbeständen der Rotbuche: Struktur, Dynamik und interspezifische Konkurrenz. Berlin, Germany: Cramer.

Hertel D, Leuschner C. 2006. The in situ root growth chamber: A novel tool for the experimental analysis of root competition in forest soils. Pedobiologia 50: 217-224.

Hodge A. 2006. Plastic plants and patchy soils. Journal of Experimental Botany 57: 401-411. 
Holzapfel C, Alpert P. 2003. Root cooperation in a clonal plant: connected strawberries segregate roots. Oecologia 134: 72-77.

Huston M. 1979. A general hypothesis of species diversity. American Naturalist 113: 81-101.

IPCC 2007. Climate Change 2007: The Physical Science Basis - 4AR. Geneva, Switzerland: The Intergovernmental Panel on Climate Change.

Jackson RB, Caldwell MM. 1991. Kinetic responses of Pseudoroegneria roots to localized soil enrichment. Plant and Soil 138: 231-238.

Jackson RB, Caldwell MM. 1993. The scale of nutrient heterogeneity around individual plants and its quantification with geostatistics. Ecology 74: 612-614.

Jackson RB, Caldwell MM. 1996. Integrating resource heterogeneity and plant plasticity: Modelling nitrate and phosphate uptake in a patchy soil environment. Journal of Ecology 84: 891-903.

Kajimoto T, Osawa A, Matsuura Y, Abaimov AP, Zyryanova OA, Kondo K, Tokuchi N, Hirobe M. 2007. Individual-based measurement and analysis of root system development: Case studies for Larix gmelinii trees growing on the permafrost region in Siberia. Journal of Forest Research 12: 103-112.

Keddy PA. 1989. Competition. London, UK: Chapman and Hall.

Korn S. 2004. Experimental investigation of water uptake and hydraulic properties of the root system of six European tree species (In German). PhD thesis, University of Göttingen, Germany.

Korstian CF, Coile TS. 1938. Plant competition in forest stands. Durham, USA: Duke University.

Kozlowski TT, Kramer PJ, Pallardy SG. 1991. The physiological ecology of woody plants. San Diego, USA: Academic Press.

Leuschner C, Coners H, Icke R. 2004. In situ measurement of water absorption by fine roots of three temperate trees: species differences and differential activity of superficial and deep roots. Tree Physiology 24: 1359-1367.

Lõhmus K, Oja T, Lasn R. 1989. Specific root area - A soil characteristic. Plant and Soil 119: 245-249.

Mahall BE, Callaway RM. 1991. Root communication among desert shrubs. PNAS 88: 874-876.

Moore B. 1929. Root competition versus light under forests. Ecology 10: 268.

Moreno G, Obrador JJ, Cubera E, Dupraz C. 2005. Fine root distribution in Dehesas of Central-Western Spain. Plant and Soil 277: 153-162.

Nambiar EKS, Sands R. 1993. Competition for water and nutrients in forests. Canadian Journal of Forest Research 23: 1955-1968.

Newbery DM, Newman EI. 1978. Competition between grassland plants of different initial sizes. Oecologia 33: 361-380.

Newman EI. 1973. Competition and diversity in herbaceous vegetation. Nature 244: 310.

Nye PH, Tinker PB. 1977. Solute movement in the soil-root system. Berkeley, USA: Blackwell.

Osenberg CW, Sarnelle O, Cooper SD, Holt RD. 1999. Resolving ecological questions through metaanalysis: Goals, metrics, and models. Ecology 80: 1105-1117.

Ostonen I, Lõhmus K, Lasn R. 1999. The role of soil conditions in fine root ecomorphology in Norway spruce (Picea abies (L.) KARST.). Plant and Soil 208: 283-292.

Peltzer DA, Wilson SD, Gerry AK. 1998. Competition intensity along a productivity gradient in a lowdiversity grassland. American Naturalist 151: 465-476.

Powell GW, Bork EW. 2006. Aspen canopy removal and root trenching effects on understory vegetation. Forest Ecology and Management 230: 79-90.

Poyatos R, Martínez-Vilalta J, Čermák J, Ceulemans R, Granier A, Irvine J, Köstner B, Lagergren F, Meiresonne L, Nadezhdina N, Zimmermann R, Llorens P, Mencuccini M. 2007. Plasticity in hydraulic architecture of Scots pine across Eurasia. Oecologia 153: 245-259.

Rajaniemi TK. 2003. Evidence for size asymmetry of belowground competition. Basic and Applied Ecology 4: 239-247. 
Rajaniemi TK. 2007. Root foraging traits and competitive ability in heterogeneous soils. Oecologia 153: $145-152$

Raynaud X, Leadley PW. 2004. Soil characteristics play a key role in modelling nutrient competition in plant communities. Ecology 85: 2200-2214.

Raynaud X, Leadley PW. 2005. Symmetry of belowground competition in a spatially explicit model of nutrient competition. Ecological Modelling 189: 447-453.

Rewald B, Leuschner C. 2008. Belowground competition in a broad-leaved temperate mixed forest pattern analysis and experiments in a four-species stand. Submitted.

Riegel GM, Miller RF, Krueger WC. 1995. The effects of aboveground and belowground competition on understory species composition in a Pinus ponderosa forest. Forest Science 41: 864-889.

Robinson D, Linehan DJ, Gordon DC. 1994. Capture of nitrate from soil by wheat in relation to root length, nitrogen inflow and availability. New Phytologist 128: 297-305.

Robinson D, Hodge A, Griffiths BS, Fitter AH. 1999. Plant root proliferation in nitrogen-rich patches confers competitive advantage. Proceedings of the Royal Society of London - B 266: 431-435.

Ross MA, Harper JL. 1972. Occupation of biological space during seedling establishment. Journal of Ecology 60: 77-88.

Schenk HJ. 2006. Root competition: beyond resource depletion. Journal of Ecology 94: 725-739.

Schoener TW. 1983. Field experiments on interspecific competition. American Naturalist 122: 240-285.

Schwinning S, Fox GA. 1995. Population-dynamic consequences of competitive symmetry in annual plants. Oikos 72: 422-432.

Schwinning S. 1996. Decomposition analysis of competitive symmetry and size structure dynamics. Annals of Botany 77: 47-57.

Schwinning S, Weiner J. 1998. Mechanisms determining the degree of size asymmetry in competition among plants. Oecologia 113: 447-455.

Seabloom EW, Harpole WS, Reichman OJ, Tilman D. 2003. Invasion, competitive dominance, and resource use by exotic and native California grassland species. Proceedings of the National Academy of Science 100: 13384-13389.

Skovsgaard JP. 1997. Management of Sitka spruce without thinnings. Hørsholm, Denmark: Danish Forest and Landscape Research Institute.

Stoll P, Prati D. 2001. Intraspecific aggregation alters competitive interactions in experimental plant communities. Ecology 82: 319-327.

Taylor JH, Peterson CA. 2005. Ectomycorrhizal impacts on nutrient uptake pathways in woody roots. New Forest 30: 203-214.

Thomas SC, Weiner J. 1989. Including competitive asymmetry in measures of local interference in plant populations. Oecologia 80: 349-355.

Tilman D. 1982. Resource competition and community structure. Princeton, USA: University Press.

Tilman D. 1988. Plant strategies and the dynamics and structure of plant communities. Princeton, USA: University Press.

Twolan-Strutt L, Keddy PA. 1996. Above- and belowground competition intensity in two contrasting wetland plant communities. Ecology 77: 259-270.

Umeki K. 1997. Effect of crown asymmetry on size-structure dynamics of plant populations. Annals of Botany 79: 631-641.

van Baalen J, Kuiters AT, van der Woude CSC. 1984. Interference of Scrophularia nodosa and Digitalis purpurea in mixed seedling cultures, as affected by the specific emergence date. Acta Oecologia 5: 279-290.

Van Lear DH, Kapeluck PR. 1995. Above- and below-stump biomass and nutrient content of a mature Loblolly pine plantation. Canadian Journal of Forest Research 25: 361-367.

von Wettberg EJ, Weiner J. 2003. Larger Triticum aestivum plants do not preempt nutrient-rich patches in a glasshouse experiment. Plant Ecology 169: 85-92. 
Wang Q, Cheng Y. 2004. Response of fine roots to soil nutrient spatial heterogeneity (In Chinese). Ying Yong Sheng Tai Xue Bao 15: 1063-1068.

Weiner J. 1986. How competition for light and nutrients affects size variability in Ipomoea tricolor populations. Ecology 67: 1425-1427.

Weiner J. 1990. Asymmetric competition in plant populations. Trends in Ecology and Evolution 5: 360-364.

Weiner J, Wright DB, Castro S. 1997. Symmetry of below-ground competition between Kochia scoparia individuals. Oikos 79: 85-91.

Welbank PJ. 1961. A study of the nitrogen and water factors in competition with Agropyron repens (L.) BEAUV.. Annals of Botany 25: 116-137.

Welden CW, Slauson WL, Ward RT. 1988. Competition and abiotic stress among trees and shrubs in Northwest Colorado. Ecology 69: 1566-1577.

Weltzin JF, Loik ME, Schwinning S, Williams DG, Fay PA, Haddad BM, Harte J, Huxman TE, Knapp AK, Lin GH, Pockman WT, Shaw MR, Small EE, Smith MD, Smith SD, Tissue DT, Zak JC. 2003. Assessing the response of terrestrial ecosystems to potential changes in precipitation. Bioscience 53: 941-952.

Wichmann L. 2001. Annual variations in competition symmetry in even-aged Sitka spruce. Annals of Botany 88: 145-151.

Williams M, Yanai RD. 1996. Multi-dimensional sensitivity analysis and ecological implications of a nutrient uptake model. Plant and Soil 180: 311-324.

Wilson JB. 1988. Shoot competition and root competition. Journal of Applied Ecology 25: 279-296.

Wilson SD, Tilman D. 1993. Plant competition and resource availability in response to disturbance and fertilization. Ecology 74: 599-611.

Wilson SD. 1993. Belowground competition in forest and prairie. Oikos 68: 146-150.

Zegada-Lizarazu W, Izumi Y, Iijima M. 2006. Water competition of intercropped Pearl millet with cowpea under drought and soil compaction stresses. Plant Production Science 9: 123-132. 
Chapter 6

\section{SYNTHESIS}




\subsection{BELOWGROUND ADAPTATIONS OF TREES TO WATER SHORTAGE AND THE ROLE OF COMPETITIVE INTERACTIONS}

The flow of water into, through and ultimately out of plants is driven by transpiration and, thus, powered by the atmospheric demand for water vapour (Hellkvist et al. 1974, Tyree 1997). Water flow in the soil-plant-atmosphere continuum (SPAC) is not only characterised by the rate of transpiration, but hydraulic conductances of soil and plant tissues play important roles as well (Gardner 1965, Tyree and Zimmermann 2003). Approximately $50 \%$ of the whole-plant hydraulic resistance are located in the root system, which shows the outstanding importance of this organ of water uptake within the flow path (Boyer 1971, Zimmermann 1983).

Water transfer from the soil to the atmosphere is more complex in mixed forests than in monospecific stands because (i) competitive interactions can influence the abundance, distribution and morphology of root systems, and (ii) other species may increase or reduce soil moisture in a different manner than conspecific tree individuals do (McKay and Malcolm 1988, Caldwell et al. 1998, Schmid and Kazda 2002, Filella and Penuelas 2003).

This chapter synthesizes results on effects of (i) water shortage and (ii) soil salinity on the morphology and function of tree root systems with respect to water uptake. Since both water shortage and salinity reduce soil water potentials, plant responses to drought and salt stress bear striking similarities.

Root system biomass under water shortage and the role of inter-specific competition

Changes in root biomass are an important means of adjustment to altered soil moisture levels (Osunubi and Davies 1981). It has been well documented that tree species adapted to more xeric conditions have higher root:shoot ratios (e.g. Joslin et al. 2000), thus, increasing the ratio between water absorbing and transpiring surface. However, results for both seedlings and mature trees grown under experimentally altered moisture regimes, or studied along moisture gradients, are contradictional (see Tables A 1, A 2). Apparently, direction and magnitude of root biomass response to drought largely depend not only on tree species or even variety, but also on study duration and/or study design (e.g. light regime, see Climent et al. 2006). 
However, increases of root biomass increases in response to drought have mostly been found in conifer species, which are known to differ in their root growth strategies from deciduous broad-leaved trees (Bauhus and Messier 1999).

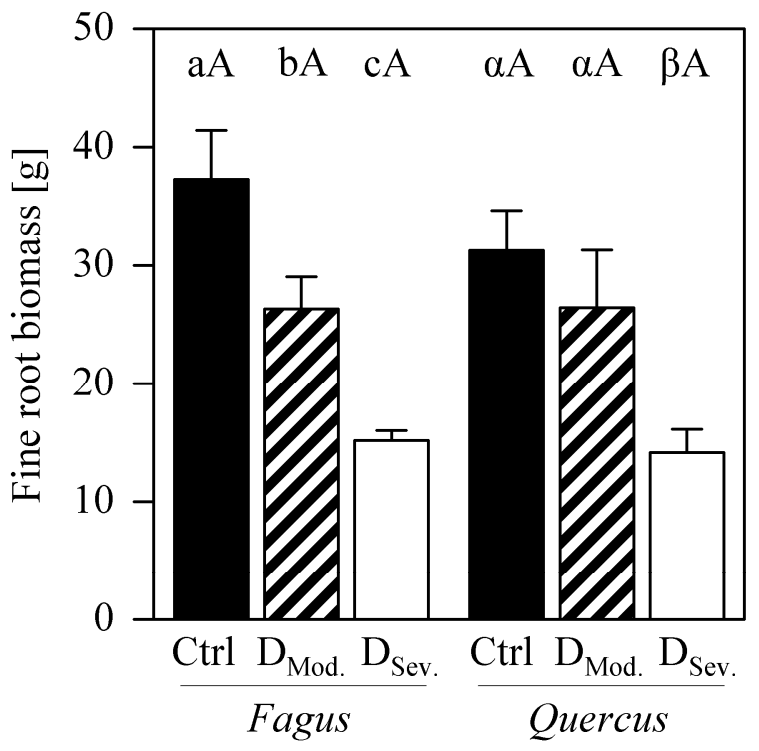

Fig. 6.1 Fine root biomass of Fagus sylvatica and Quercus petraea saplings after three years of different soil moisture treatment, i.e. well-watered Control $(\mathrm{Ctrl})$, moderate drought stress $\left(\mathrm{D}_{\mathrm{Mod}}\right)$, and severe drought stress $\left(\mathrm{D}_{\mathrm{Sev}}\right.$; see Chapter 2$)$. Significant differences within species are indicated by different Latin or Greek lower case letters, and significant differences within moisture treatments are indicated by capitals (Scheffé, $\mathrm{p}<0.05$, mean $+\mathrm{SE}, n=8-10$ ).

Studies on mature trees and saplings of Fagus sylvatica, Quercus petraea and Olea europaea indicate mostly unaltered or decreased fine root biomasses in response to drought or salinity (Tables A 1, A 2), which is in consistency with results obtained in this study (Figs. 6.1, 6.2). Several factors may be responsible for the observed decrease in root system size under water shortage: e.g. (i) reduced root elongation at low water potentials, and/or (ii) increased root mortality, and reduced root growth due to reduced carbohydrate supply, or, in the case of adult trees, a (iii) shift of root biomass into deeper, wetter soil horizons. Especially root growth of Fagus sylvatica may be hampered by carbon limitation whereas Quercus petraea is known to maintain high rates of photosynthesis even with low leaf water potentials (Raftoyannis and Radoglou 2002).

Root biomass is known to be influenced by belowground competition. This study and Leuschner et al. 2001 observed remarkably small fine root biomasses (Fig. 4.2) and an over-proportional reduction of root growth rates (Table 4.6) of Quercus petraea in mixed forests stands if compared to mono-specific oak woods. This finding has been attributed to competitive replacement of oak roots by beech roots and has been reported for other mixed forest stands as well (e.g. Schmid and Kazda 2002, Bolte 
and Villanueva 2006). The competitive superiority of beech (Fig. 4.5), based on a putative correlation between fine root biomass and resource uptake, is especially astonishing in the Ziegelrodaer forest, where annual rainfall (mean annual precipitation: approx. $520 \mathrm{~mm}$ ) is close to the assumed precipitation-induced range margin of Fagus sylvatica (Ellenberg 1996). However, a comparison of the belowground competitive abilities of beech and oak along a soil moisture gradient (Fig. 5.2) revealed, that the difference between intra- and interspecific competitive abilities of the two tree species decreased with increasing soil moisture deficits. Consequently, species-specific traits of water uptake strategies are assumed to be more important than the competitive abilities of the species under severe droughts.

\section{Root topology and water redistribution in mixed and mono-specific forest stands}

Root architecture and distribution in the soil are of great importance as they determine plant access to water (Ryel et al. 2004). Although fine root density mostly shows an exponential decrease with soil depth (Figs. 4.2, 6.2; Gale and Gringal 1987, Leuschner et al. 2004b), deeper root systems would enable access to subsurface resources of water (Köstler 1968, Kozlowski et al. 1991, Jackson et al. 1999). Especially Quercus spp. have been found to successfully avoid drought stress by deep rooting (Čermák et al. 1980, Badot et al. 1994, Bréda et al. 1995), whereas Fagus sylvatica roots are less frequent in greater depths (Leuschner et al. 2001).

Even though, this study (Fig. 6.2) and that of Leuschner et al. (2001) showed fine root biomass of oak and beech to be similar in conspecific patches of the Unterlüß forest, both species seem to respond differently to drought. While the fine root biomass of oak was significantly reduced after three months of experimentally-induced summer drought, beech was found to grow new fine roots in the upper soil horizons even under severe drought (Fig. 6.2; see Mainiero and Kazda 2006). Since there is no evidence for rapid root growth responses to drought stress in Fagus sylvatica (Mainiero and Kazda 2006) or Quercus spp. (Konôpka et al. 2005), this conservative strategy of fine root investment by Fagus is suggested to be only favourable under more mesic conditions (see Green and Clothier 1995). It is possible that a less flexible carbon-investment strategy and the subsequently increased fine root turnover (Mainiero and Kazda 2006) are partly involved in the higher drought sensitivity of beech. 


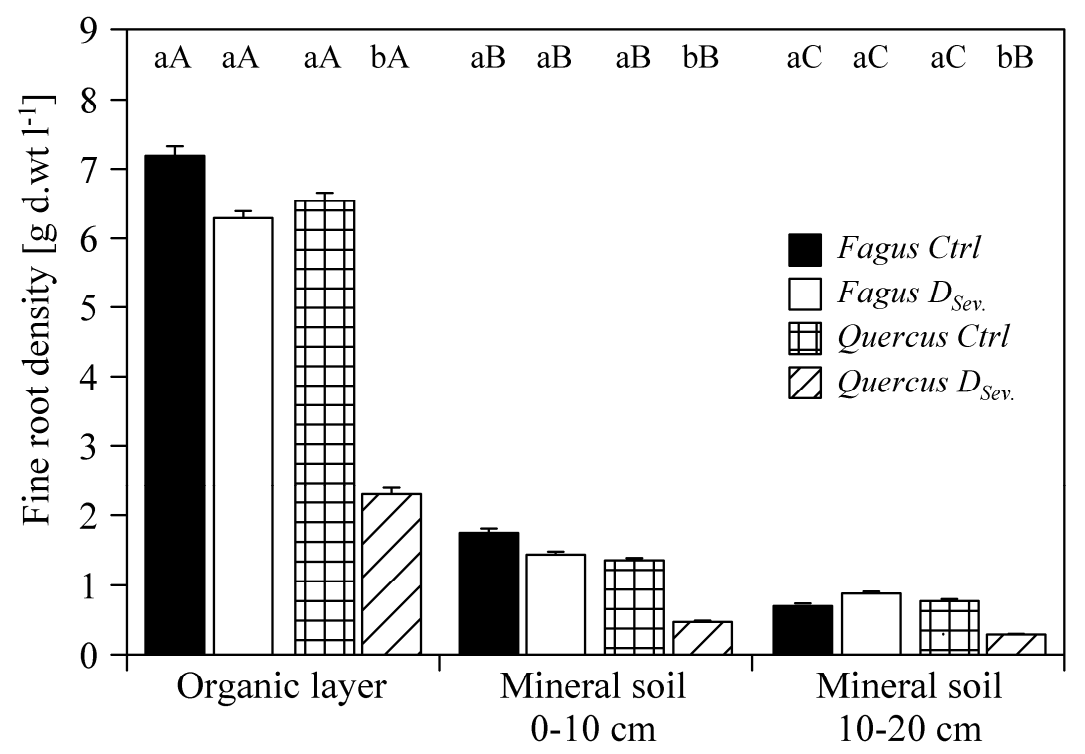

Fig. 6.2 Fine root densities of mature Fagus sylvatica and Quercus petraea trees after three month of different soil moisture treatment, i.e. ambient-watered Control $(\mathrm{Ctrl})$, and severely drought-stressed $\left(\mathrm{D}_{\mathrm{Sev}}\right.$, see Chapter 2). Significant differences within the three soil horizons are indicated by different lower case letters, and significant differences between soil horizons are indicated by capitals (Scheffé, $\mathrm{p}<0.05$, mean + SE, $n=20$; Rewald, Prigge and Leuschner, unpublished).

Soil moisture is often highly variable within soil horizons (Staelens et al. 2006), and the capability of root systems to explore the soil for heterogeneously distributed moisture might be crucial for successful water uptake (Fig. 4.3; Cole and Mahall 2006). Although it is known that water uptake of individual Fagus and Quercus roots can differ within soil horizons (Coners and Leuschner 2005), possibly resulting from moisture differences, studies about species-specific differences in the detection of water, e.g. via hydrotropism, are lacking. Such foraging traits might be very important in densely rooted mixed forests (Table 4.4, Fig. 5.1), where competitors could potentially pre-empt moist soil patches.

Rooting in soil patches with different moisture content can induce a transfer of water from wet soil to dry soil via 'hydraulic lift' (Caldwell et al. 1998) or 'hydraulic redistribution' (Burgess et al. 1998, Schulze et al. 1998). Hydraulic redistribution can re-wet dry topsoil layers, thus, possibly facilitating nutrient uptake, and buffering plants against water deficits. Moisture distributed more uniformly in the soil column may retard water uptake by reducing soil conductivity, thus, prolonging water availability during periods of drought (Richards and Caldwell 1987, Ryel 2004, Pereira et al. 2006). Furthermore, the effectiveness of water absorption by deep roots and the survival of shallow roots in dry soil are suggested to be increased by hydraulic lift (Caldwell and Richards 1989, Seyfried et al. 2005). A weakness of plant-mediated water relocation is 
that water from moist soil horizons or even plant-internal water (Matyssek et al. 1991) may leak into dry soil along the flow path. 'Hydraulic fuse'-mechanisms that are assumed to prevent or reduce such leakage are: (i) shedding of fine root branches (Head 1973, Pereira et al. 2004), (ii) suberization of the rhizodermis and/or aquaporin regulation, or (iii) increase of the resistance of the hydraulic pathway by cavitation (discussed below).

\section{Influence of drought on root morphology}

Root morphology is another parameter with the potential to adapt to altered soil moisture. Nevertheless, the overall root architecture is genetically determined (Zobel 1991, Gregory 2006). The detection of adaptational mechanisms is hampered by the large variation of root morphology and architecture within species or individuals, possibly caused by soil heterogeneity (Fitter 1994, Meier and Leuschner 2008a). In contrast to previous studies (e.g. Hertel 1999), this study neither revealed significant differences in the specific root area (SRA) between well-watered Fagus and Quercus trees in the Unterlüß forest (Table 5.3), nor between roots of both species from low rainfall areas such as the Ziegelrodaer forest (Table 4.3).

It is a general presumption that finest roots are most effective with regard to water uptake (e.g. Rieger and Litvin 1999, Lindenmair et al. 2004). Thus, SRA could be expected to increase during drought. In contrast to this assumption, SRA of Fagus and Quercus in the Unterlüß forest decreased under reduced water availability (Table 5.3), which is in accordance with previous findings for Fagus and other species (e.g. Aspelmeier and Leuschner 2006, Meier and Leuschner 2008b). The underlying mechanisms must remain speculative, but may include increased mortality/shedding of root tips and finest roots, the (re-)growth of less ramified roots by increased turnover rates (see Table A 2), and, for beech, increased root tissue densities (Table 2.3).

Root elongation rate, which is positively correlated with root diameter, is an even more important attribute for maximizing uptake rates of low-diffusive nutrients such as phosphorous than root surface area (Silberbush and Barber 1983, Raven and Edwards 2001). In order to tap more soil regions with plant-available water, higher elongation rates are suggested to be most favourable in soil with a heterogeneous distribution of moisture or in the case of inter-specific competition for water. Quercus petraea roots are suggested to be superior to Fagus sylvatica in accessing distinct water patches in heterogeneous soils, as indicated by their faster growth (RGR) and less ramified root branches 
(SRA; Table 4.6, Fig. 5.1). Furthermore, roots of smaller diameter (and larger SRA) have higher construction and maintenance costs per unit biomass than larger roots (Eissenstat and Yanai 1997). Most likely, there must be a trade-off between the benefits of a large absorbing surface area per unit biomass and an increased contact with the soil, and the benefits of increased 'long-distance' foraging and reduced maintenance costs under water shortage.

Rates of water uptake per root surface area vary significantly between individual roots, species and sites with different climate (Korn 2004, Burk 2006). Fagus has been found to possess higher root-surface-area related sap-flow rates than Quercus (Coners and Leuschner 2002). Furthermore, even under well-watered conditions, beech roots showed lower root surface-specific flows on a site with a more oceanic climate than on a more continental site (Burk 2006), indicating a yet unknown, but highly plastic uptake pattern of beech roots growing on dryer sites. Unfortunately, no information is available about such plasticity in oak uptake kinetics. However, during periods of severe drought, this trait of Fagus might turn into a disadvantage, if water in the rhizosphere is depleted too fast, causing an interruption of the SPAC at the soil-root interface.

These reports on different surface-related water uptake rates substantiate the evidence of asymmetric competition between beech and oak (Table 4.6, Fig. 5.1). Whether water or nutrient uptake, allelopathic chemicals, soil fauna or microorganism are the underlying mechanism of these competitive interactions remains unclear, but different uptake kinetics are feasible explanations. Earlier studies and models, which indicate either symmetric or asymmetric competition belowground, are listed in Tables A 3 - A 5.

\section{Adaptability of root physiology to water shortage}

The capacity of roots for water uptake is determined not only by root surface area, but by other properties, in particular the resistance of tissues to water transport, as well. Drought and salinity are known to induce short- and long-term alterations of the radial pathway, usually resulting in an increase of radial resistance (Huang and Nobel 1993, Steudle 2000).

Water channel proteins in the cell membranes (aquaporins) mediate the short-term adjustment of the symplastic pathway to salt or drought stress (Yamada 1997, Katsuhara and Shibasaka 2007). Although data for woody plants is scarce (for olive see Lovisolo et al. 2007), studies on herbaceous plants suggest that aquaporins are present in virtually 
all root types (Kirch et al. 2000, Otto and Kaldenhoff 2000, Kaldenhoff and Fischer 2006), and especially in cells that control water uptake and radial water flow (Schäffner 1998). The regulation of root aquaporins enables a very tight coupling between root water uptake and whole plant physiology, e.g. by facilitating water flow under moist conditions, or reducing water loss to the soil via unintended hydraulic redistribution by 'more tight' membranes. A higher expression of aquaporins, and, thus, higher root surface area-specific conductance, is suggested to compensate for a reduced root system size in salt- and drought-stressed olive trees, explaining in part the above-average drought- and salt-tolerance of this species (Lovisolo et al. 2007). Although no studies on aquaporins in Fagus and Quercus roots have been published yet, increased aquaporin densities are likely to be involved in the high surface area-related sap flow rates of Fagus roots.

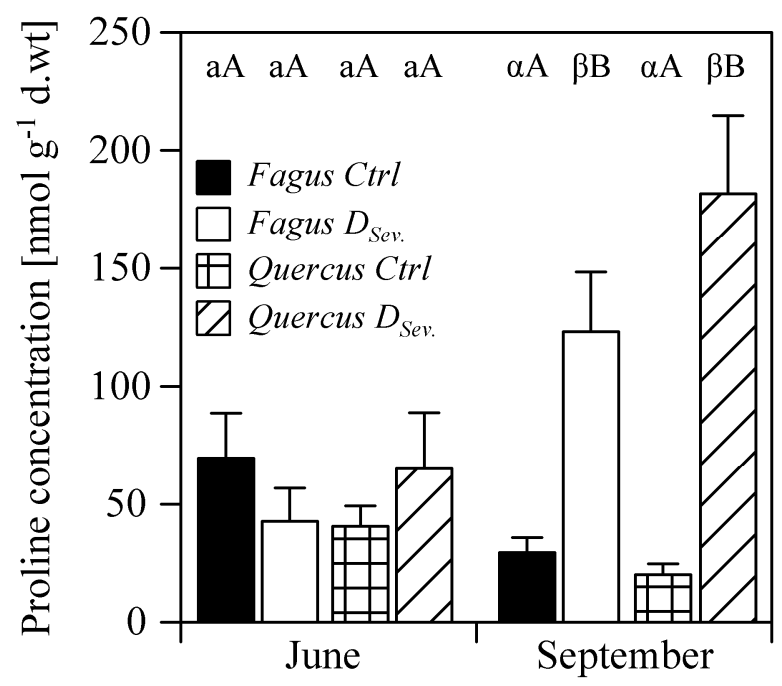

Fig. 6.3 Proline concentration in fine roots (diameter $<2 \mathrm{~mm}$ ) of mature Fagus sylvatica and Quercus petraea trees before (June 2004) and after (September 2004) a three month-period of different soil moisture availability (see Chapter 2). Soil moisture treatments are ambient-watered Control (Ctrl), and severe drought stress $\left(\mathrm{D}_{\mathrm{Sev}}\right)$. Significant differences between species at one date are indicated by different Latin or Greek lower case letters, and significant differences between June and September are indicated by capitals (Scheffé, $\mathrm{p}<0.05$, mean $+\mathrm{SE}, n=2-5$; Rewald, Prigge and Leuschner, unpublished).

Another mechanism, supposedly allowing plants to tolerate periods of water shortage is osmotic adjustment (Chaves et al. 2003). Osmotic adjustment enables sustained root growth under moderate levels of drought stress by partial turgor recovery and maintenance of the ability to loosen cell walls (Hsiao and $\mathrm{Xu} 2000$ ). Proline is an important component in osmoregulation, its concentrations have been found to increase strongly in response to drought or salt stress and have been suggested to explain differences in drought- and salt-tolerances (Hare et al. 1998, de Lacerda et al. 2003, Ennajeh 2006, Garcia-Sánchez et al. 2007). This study revealed a significant increase in proline con- 
centrations in fine roots of mature Fagus and Quercus trees after three months of severe drought stress (Fig. 6.3). Although not statistically significant, drought-stressed oak roots exhibited a tendency to higher proline concentration than fine roots of beech, thus indicating higher levels of osmotic adjustment.

In general, water shortage is thought to facilitate suberization of the root rhizodermis, subsequently limiting the apoplastic by-pass and reducing the radial conductivity of roots (Zimmermann and Steudle 1998). However, previous studies provide convincing evidence of water uptake even by strongly suberized regions of woody roots (Chung and Kramer 1975, MacFall et al. 1990, 1991). Increased root suberization under drought or salt stress might therefore correlate better with general stress-tolerance (Cruz et al. 1992, Schreiber et al. 2005), instead of explaining different water uptake rates (Leuschner et al. 2003, Korn 2004).

\section{Mycorrhizal fungi and drought stress}

Considerable uncertainty exists about the influence of fungal hyphae on host hydraulics and water uptake (Hampp and Schaeffer 1999, Nardini et al. 2000) and responses of the fungal community to drought (Shi et al. 2002). Due to the large contact area between hyphae and soil particles, mycorrhiza formation has been suggested to improve water availability of the host plants (Duddridge et al. 1980, McFall 1991, Augé 2001), and to support acclimation to drought stress (Davies et al. 1996, George and Marschner 1996). While Steudle and Heydt (1997) found only a marginal influence of mycorrhization on beech saplings water uptake rate, oaks showed a strong decline in transpired water, derived by hydraulic lift, after severing the mycorrhizal hyphae net (Egerton-Warburton et al. 2003). Furthermore, hyphae were found to transfer water between roots of 'donor' Quercus individuals, performing hydraulic lift, and 'receiver' plants, possibly resulting in multiple benefits during drought as enhanced water and nutrient uptake and/or redistribution (Leake et al. 2004), or a rapid recovery from desiccation or refilling of embolized vessels. However, it has to remain open if similar mechanisms exist in beech and if the quantities of redistributed water account for significant reduction of drought stress in oak. 


\section{Changes in root axial conductivity under drought and salt stress}

Different species or even genotypes of woody plants may differ substantially with respect to root axial conductivity (e.g. Huber 1956, Larcher 2001). However, the fine and coarse roots of ring-porous oak and diffuse-porous beech showed no systematic differences with regard to their specific conductivity $\left(k_{s}\right)$ or sap flow density (Korn 2004), whereas root $\mathrm{k}_{\mathrm{s}}$ of the three olive varieties partially differed. In contrast to these findings, Quercus shoots showed higher specific conductivities than Fagus shoots (see Fig. 2.2, and Steppe and Lemeur 2007), but only minor differences were found between shoot $\mathrm{k}_{\mathrm{s}}$ of the three olive varieties. These results highlight the variability of axial hydraulic conductivity between organs.

A majority of previous studies has reported reduced root and shoot axial conductivities in response to drought and salinity (see Tables A 6, A 7), thereby improving plant water status by reducing water loss to the atmosphere and the soil (North and Nobel 1992, Meinzer et al. 1996, Trillo and Fernández 2005). While the reduced shoot conductivities under water shortage found in this study (Fig. 2.2) are in accordance with a bulk of earlier literature, no general reduction of fine and coarse root axial hydraulic conductivity in response to either drought or salt stress could be detected (Figs. 2.1, 3.3, Table 3.4).

An increase of root axial conductivity has been suggested to facilitate water uptake by reducing the flow resistance (Nardini and Pitt 1999). Although it has previously been considered a minor limitating factor of whole-root conductivity as compared to radial conductivity (Sands et al. 1982, Steudle 1994), Hacke et al. (2000) demonstrated that whole-plant water use and axial conductivity of woody plants during drought stress were in accordance. Especially the large root systems of adult trees with a great path length (West et al. 1999, Magnani et al. 2000, Addington et al. 2006) and reduced potential gradients due to large root:leaf area ratios (Grier et al. 1981, Vanninen et al. 1996) illustrate the importance of sufficient root axial conductivities. This fact is mirrored by the higher axial conductivities of roots of mature trees if compared to those of saplings (Table 2.3). Since knowledge about ontogenetic influences on the hydraulic system is still scarce (Ito et al. 1995, Mencuccini 2002), a non-competed metaxylem maturation in sapling roots could have caused these differences as well (Staubin et al. 1986, Vercambre et al. 2002, Tyree 2003).

Increases of root conductivity would be particularly straightforward adaptations in plants that respond to drought or salt stress with a reduction of fine root biomass (see Figs. 6.1, 6.2, and Weissbein 2006). The extent of root biomass reduction may ex- 
plain the different response of root conductivity in mature beech and oak trees to drought (Fig. 2.1, Table 2.3). The minor reduction of root biomass of mature beech trees might have made an increase of root axial conductivity unnecessary (Fig. 6.2). Nevertheless, this study is one of very few reports that show that salinity- and droughtinduced losses in root biomass may partly be compensated by increases of root hydraulic conductivity, when drought stress is not too severe (Figs. 2.1a, 3.3, Table 3.4). Although the underlying mechanisms must remain speculative, they are likely to include the re-growth of fine roots as indicated by the increased turnover rates (Table A 2), and modifications of secondary growth in coarse roots.

Another adaptation of the tree root hydraulic system to soil water shortage might be the development of root branches with diverging hydraulic properties, thereby exploring the spatial heterogeneity of water reserves, as is typical for temporally drought-exposed (Göttlein and Manderscheid 1998) and saline soils (Oron et al. 1999). In most of the beech, oak and olive roots examined in this study, a very large variation in root axial conductivity was found, with outliers showing up to 100 times higher $\mathrm{k}_{\mathrm{s}}$ values than the sample mean (Figs. 2.1, 3.1, 3.3). Such high conductivity roots were found in the freshor well-watered control treatments as well as under salt/drought application, but the variability of fine root axial conductivity generally increased in root samples exposed to moderate or severe drought and in the salt-treated roots of Barnea variety (Fig. 3.1). Several previous studies have documented that root axial conductivity and water uptake rate can differ substantially within root systems, e.g. between deep and shallow roots (Pate et al. 1995, Korn 2004, Leuschner et al. 2004a). Since individual roots or root branches are thought to act as 'physiologically autonomous units' (Shani et al. 1993), the differentiation of the root population into high-conductivity and low-conductivity roots has been postulated as a favourable adaptation to heterogeneous environments. Consequently, the larger variability of hydraulic conductivity within the severely drought-stressed root systems of oaks if compared to beech, and the large intra-vascular and intra-root system variability in the roots of Olea europaea var. Barnea indicate their better adaptation to soil containing heterogeneous distributed moisture.

\section{Influence of water shortage on root hydraulic safety}

It has been thought for long that an increased axial conductivity is associated with an increasing risk to cavitation (Hargrave et al. 1994). Now there is convincing evidence that the susceptibility to drought stress-induced cavitation depends on the size of 
pit membrane pores between adjacent conduits rather than vessel diameter (Jarbeau et al. 1995, Alder et al. 1996, Pockman and Sperry 2000). Accordingly, this study revealed no correlation between root axial conductivity and the degree of root embolism (Tables $2.3,3.4$ ) and consequently no conductivity-safety trade-off in roots, as has been found previously in beech branches by Cochard et al. (1999).

While some embolism may occur even in roots of well-watered plants (Table 2.3; see Alder et al. 1996, Domec et al. 2004), fine roots have been suggested to be weak, replaceable segments of the soil-plant-atmosphere continuum (Sperry and Saliendra 1994, Domec et al. 2004), expedient to uncouple parts of the SPAC in response to more severe water shortage. Acting as 'hydraulic fuses' (Zimmermann 1983), they are thought to prevent plant-wide cavitation and water loss to the soil, as resulting from unintended hydraulic redistribution (Nobel and North 1992, Sperry and Ikeda 1997, Hacke et al. 2000). As previously discussed, root shedding and probably aquaporin regulation, are involved in this function. Cavitation is suggested to be another, possibly reversible, 'hydraulic fuse' mechanism in roots. The slightly negative water potential inducing 50\% loss of conductivity in beech and oak roots (Fig. 2.3, Table 2.4) support this hypothesis, as does the significant increase of $\Psi_{\text {PLC50 }}$ in drought-stressed Quercus roots (Table 2.4). There is now convincing evidence that embolism is reversible in many cases (Pickard 1989, Tyree et al. 1986, Zwieniecki and Holbrook 1998, Lovisolo and Schubert 2006). Although the mechanisms are still largely unknown, the active secretion of osmotic solutes, possibly via aquaporins, by adjacent living cells is likely to be involved (Holbrook and Zwieniecki 1999, Sakr 2003). The ability to repair cavitated vessels has profound implications, i.e. root embolism could be favourable if it prevents water loss to the soil without costly shedding of roots. Thus, the significantly increased vulnerability to cavitation in drought-stressed Quercus petraea roots seems to be a straightforward adaption to drought rather than an impairment by drought, in particular if root system size is already reduced and further root shedding cannot be afforded. 


\subsection{CONCLUSIONS}

The study of drought- and salt-resistance strategies has classically focused on the dynamics of stem and leaf water relations such as leaf water status (Lo Gullo and Salleo 1988, Fotelli et al. 2000, Aasamaa et al. 2004), stem sap flow (Čermák et al. 1993, Leuzinger et al. 2005), evaporative flux (Reich and Hinckley 1989), and stem and leaf vulnerability to cavitation (Harvey and van den Driessche 1997, Sperry and Tyree 1988). However, it is in the soil were water uptake occurs and plant individuals compete for water and other resources. Although an increasing number of studies has been addressing belowground traits (e.g. Levy et al. 1983, Hendriks and Bianchi 1995, McPhee 1998, Blake and Li 2003, de Kroon et al. 2003), a better understanding of the adaptability of tree root systems to water limitation and belowground competition is still urgently needed to enable predictions on the effects of climate change on mature forest stands.

Four main hypotheses were tested in this study to answer some important questions in this field:

i) The adaptive mechanisms of root hydraulic systems are analogue to those in aboveground organs.

This study suggests that Quercus fine and coarse roots are capable of responding more flexibly to drought in terms of root topology and physiology than beech roots: fine and coarse roots of Quercus generally responded with an increase of axial conductivity to moderate or severe drought, while those of Fagus mostly did not. The same pattern was found in salt-stressed Olea europaea roots, the conductivity of which increased with increasing salinity. This is in contrary to effects in shoots, where conductivity generally decreases in response to drought or salinity, disproving the hypothesis. Drought-adapted tree species such as Quercus petraea seem to be capable of partly compensating for drought-induced root biomass losses by increasing axial conductivity of the remaining roots, a mechanism rarely observed in aboveground organs. 
ii) Fine roots act as 'hydraulic fuses' in the soil-plant-atmosphere continuum to prevent runaway cavitation in the whole plant.

In support of the hypothesis, this study provided evidence that small-diameter roots may indeed function as fuses in the SPAC of temperate trees. In addition to most previous studies, which suggest root shedding as the underlying mechanism, this study indicates cavitation as another, potentially reversible, 'hydraulic fuse' mechanism. This conclusion is based on the very high vulnerability of small-diameter roots of both oak and beech to cavitation and the further increase of this vulnerability in drought-stressed Quercus roots.

iii) Belowground competitive ability is symmetric and linked to root system size.

In contrast to the hypothesis, this study revealed two lines of evidence for the existence of asymmetry in belowground competition: fine root biomass of Quercus petraea was over-proportionally reduced in species-rich allospecific stand patches as compared to monospecific ones, and both root growth rates and root morphology depended on the competitor present but not on initial size differences. Although the experiments do not allow conclusions about the underlying mechanisms of this asymmetric belowground interaction, pre-emption of soil water and nutrient patches by plants with larger root systems, which gain access before smaller plants do, and species-specific uptake kinetics are likely to be involved.

iv) Belowground competition ability differs between tree species and is not modified by resource availability.

In support of the hypothesis, tree species may be ranked according to their belowground competitive ability. According to root biomass data and root growth in experimentally altered neighbourhoods, beech seems to be a superior competitor belowground. However, future experimental studies in the rhizosphere of forests have to reveal what mechanisms (including resource competition, self-self inhibition, facilitation, allelopathy, or indirect competitive interactions through other organisms or agents) form the basis of the observed pattern.

This study revealed a significant correlation between competitive asymmetry $(\Delta \mathrm{CA})$, expressed as difference between species-specific competitive abilities, and cumulative soil moisture deficit. Thus, in contrast to the formulated hypothesis, marked asymmetry 
in the outcome of root competition only developed when soil moisture in summer was sufficiently high. Resource limitation, i.e. drought, seems to affect the competitive abilities of both Fagus sylvatica and Quercus petraea roots in a similar manner, with the consequence that species-specific differences in competitive ability in mixture disappear in the more stressful environment. Thus, the overall importance of direct biotic interactions belowground seems to be reduced under limited soil water availability. 


\subsection{REFERENCES}

Aasamaa K, Sober A, Hartung W, Niinemets U. 2004. Drought acclimation of two deciduous tree species of different layers in a temperate forest canopy. Trees - Structure and Function 18: 93-101.

Addington RN, Donovan LA, Mitchell RJ, Vose JM, Pecot SD, Jack SB, Hacke UG, Sperry JS, Oren R. 2006. Adjustments in hydraulic architecture of Pinus palustris maintain similar stomatal conductance in xeric and mesic habitats. Plant, Cell and Environment 29: 535-545.

Alder NN, Sperry JS, Pockman WT. 1996. Root and stem xylem embolism, stomatal conductance, and leaf turgor in Acer grandidentatum populations along a soil moisture gradient. Oecologia 105: 293-301.

Aspelmeier S, Leuschner C. 2006. Genotypic variation in drought response of Silver birch (Betula pendula Roth.): leaf and root morphology and carbon partitioning. Trees - Structure and Function 20: $42-52$.

Augé RM. 2001. Water relations, drought and vesicular-arbuscular mycorrhizal symbiosis. Mycorrhiza 11: 3-42.

Badot PM, Lucot E, Bruckert S. 1994. Soil-moisture in deep levels is the main source of mid-day water potential variations in oak (Quercus sp.). Comptes Rendus de l'Academie des Sciences Serie I ii - Sciences de la Vie 317: 341-345.

Bauhus J, Messier C. 1999. Soil exploitation strategies of fine roots in different tree species of the southern boreal forest of eastern Canada. Canadian Journal of Forest Research 29: 260-273.

Blake TJ, Li JY. 2003. Hydraulic adjustment in Jack pine and Black spruce seedlings under controlled cycles of dehydration and rehydration. Physiologia Plantarum 117: 532-539.

Bolte A, Villanueva I. 2006. Interspecific competition impacts on the morphology and distribution of fine roots in European beech (Fagus sylvatica L.) and Norway spruce (Picea abies (L.) KARST.). European Journal of Forest Research 125: 15-26.

Boyer JS. 1971. Resistances to water transport in soybean, bean, and sunflower. Crop Science 11: 403-407.

Bréda N, Granier A, Barataud F, Moyne C. 1995. Soil-water dynamics in an oak stand. 1. Soil-moisture, water potentials and water-uptake by roots. Plant and Soil 172: 17-27.

Burgess SSO, Adams MA, Turner NC, Ong CK. 1998. The redistribution of soil water by tree root systems. Oecologia 115: 306-311.

Burk D. 2006. Physiological, anatomical and chemical aspects of the regulation of water uptake by beech, pine and birch roots in two different water-supplying locations (In German). PhD thesis. University of Göttingen, Germany.

Caldwell MM, Richards JH. 1989. Hydraulic lift - Water efflux from upper roots improves effectiveness of water-uptake by deep roots. Oecologia 79: 1-5.

Caldwell MM, Dawson TE, Richards JH. 1998. Hydraulic lift: Consequences of water efflux from the roots of plants. Oecologia 113: 151-161.

Čermák J, Huzulák J, Penka M. 1980. Water potential and sap flow-rate in adult trees with moist and dry soil as used for the assessment of root-system depth. Biologia Plantarum 22: 34-41.

Čermák J, Matyssek R, Kucera J. 1993. Rapid response of large, drought-stressed beech trees to irrigation. Tree Physiology 12: 281-290.

Chaves MM, Maroco JP, Pereira JS. 2003. Understanding plant responses to drought - from genes to the whole plant. Functional Plant Biology 30: 239-264.

Chung HH, Kramer PJ. 1975. Absorption of water and ${ }^{32} \mathrm{P}$ through suberized and unsuberized roots of Loblolly pine. Canadian Journal of Forest Research 5: 229-235. 
Climent JM, Aranda I, Alonso J, Pardos JA, Gil L. 2006. Developmental constraints limit the response of Canary Island pine seedlings to combined shade and drought. Forest Ecology and Management 231: 164-168.

Cochard H, Lemoine D, Dreyer E. 1999. The effects of acclimation to sunlight on the xylem vulnerability to embolism in Fagus sylvatica L. Plant, Cell and Environment 22: 101-108.

Cole ES, Mahall BE. 2006. A test for hydrotropic behavior by roots of two coastal dune shrubs. New Phytologist 172: 358-368.

Coners H, Leuschner C. 2002. In situ water absorption by tree fine roots measured in real time using miniature sap-flow gauges. Functional Ecology 16: 696-703.

Coners H, Leuschner C. 2005. In situ measurement of fine root water absorption in three temperate tree species - Temporal variability and control by soil and atmospheric factors. Basic and Applied Ecology 6: 395-405.

Cruz RT, Jordan WR, Drew MC. 1992. Structural changes and associated reduction of hydraulic conductance in roots of Sorghum bicolor L. following exposure to water deficit. Plant Physiology 99: 203-212.

Davies FTJ, Svenson SE, Cole JC, Phavaphutanon L, Duray SA, Olalde-Portugal V, Meier CE, Bo SH. 1996. Non-nutritional stress acclimation of mycorrhizal woody plants exposed to drought. Tree Physiology 16: 985-993.

de Kroon H, Mommer L, Nishiwaki A. 2003. Root competition: Towards a mechanistic understanding. In: de Kroon H, Visser EJW, eds. Root ecology. Berlin, Germany: Springer, 215-235.

de Lacerda CF, Cambraia J, Oliva MA, Ruiz HA. 2003. Osmotic adjustment in roots and leaves of two Sorghum genotypes under $\mathrm{NaCl}$ stress. Brazilian Journal of Plant Physiology 15: 113-118.

Domec JC, Warren JM, Meinzer FC, Brooks JR, Coulombe R. 2004. Native root xylem embolism and stomatal closure in stands of Douglas fir and Ponderosa pine: Mitigation by hydraulic redistribution. Oecologia 141: 7-16.

Duddridge JA, Malibari A, Read DJ. 1980. Structure and function of mycorrhizal rhizomorphs with special reference to their role in water transport. Nature 287: 834-836.

Egerton-Warburton LM, Graham RC, Hubbert KR. 2003. Spatial variability in mycorrhizal hyphae and nutrient and water availability in a soil-weathered bedrock profile. Plant and Soil 249: 331-342.

Eissenstat DM, Yanai RD. 1997. The ecology of root lifespan. Advances in Ecological Research 27: 1-60.

Ellenberg H. 1996. Vegetation Mitteleuropas mit den Alpen in ökologischer, dynamischer und historischer Sicht. $5^{\text {th }}$ ed. Stuttgart, Germany: Ulmer.

Ennajeh M, Vadel AM, Khemira H, Ben Mimoun M, Hellali R. 2006. Defense mechanisms against water deficit in two olive (Olea europaea L.) cultivars 'Meski' and 'Chemlali'. Journal of Horticultural Science and Biotechnology 81: 99-104.

Filella I, Penuelas J. 2003. Indications of hydraulic lift by Pinus halepensis and its effects on the water relations of neighbour shrubs. Biologia Plantarum 47: 209-214.

Fitter AH. 1994. Architecture and biomass allocation as components of the plastic response of root systems to soil heterogeneity. In: Caldwell MM, Pearcy RW, eds. Exploitation of environmental heterogeneity by plants: Ecophysiological processes above- and belowground. San Diego, USA: Academic, 305-323.

Fotelli MN, Radoglou KM, Constantinidou HIA. 2000. Water stress responses of seedlings of four Mediterranean oak species. Tree Physiology 20: 1065-1075.

Gale MR, Grigal DF. 1987. Vertical root distributions of northern tree species in relation to successional status. Canadian Journal of Forest Research 17: 829-834.

Garcia-Sánchez F, Syvertsen JP, Gimeno V, Botia P, Perez-Perez JG. 2007. Responses to flooding and drought stress by two citrus rootstock seedlings with different water-use efficiency. Physiologia Plantarum 130: 532-542.

Gardner WR. 1965. Dynamic aspects of soil-water availability to plants. Annual Review of Plant Physiology 16: 323-342. 
George E, Marschner H. 1996. Nutrient and water uptake by roots of forest trees. Zeitschrift für Pflanzenernährung und Bodenkunde 159: 11-21.

Göttlein A, Manderscheid B. 1998. Spatial heterogeneity and temporal dynamics of soil water tension in a mature Norway spruce stand. Hydrological Processes 12: 417-428.

Green SR, Clothier BE. 1995. Root water-uptake by Kiwifruit vines following partial wetting of the rootzone. Plant and Soil 173: 317-328.

Gregory P. 2006. Genetic control of root system properties. In: Gregory P, ed. Plant roots: Growth, activity and interaction with soil. Oxford, UK: Blackwell, 253-285.

Grier CC, Vogt KA, Keyes MR, Edmonds RL. 1981. Biomass distribution and above-ground and belowground production in young and mature Abies amabilis zone ecosystems of the Washington Cascades. Canadian Journal of Forest Research 11: 155-167.

Hacke UG, Sperry J, Pittermann J. 2000. Drought experience and cavitation resistance in six shrubs from the Great Basin, Utah. Basic and Applied Ecology 1: 31-41.

Hampp R, Schaeffer C. 1999. Mycorrhiza-carbohydrate and energy metabolism. In: Hock B, Varma A, eds. Mycorrhiza. Berlin, Germany: Springer, 273-303.

Hare PD, Cress WA, Van Staden J. 1998. Dissecting the roles of osmolyte accumulation during stress. Plant, Cell and Environment 21: 535-553.

Hargrave KR, Kolb KJ, Ewers FW, Davis SD. 1994. Conduit diameter and drought-induced embolism in Salvia mellifera GREENE (Labiatae). New Phytologist 126: 695-705.

Harvey HP, van den Driessche R. 1997. Nutrition, xylem cavitation and drought resistance in hybrid poplar. Tree Physiology 17: 647-654.

Head GC. 1973. Shedding of roots. In: Kozlowski TT, ed. Shedding of plant parts. New York, USA: Academic Press, 237-293.

Hellkvist J, Richards GP, Jarvis PG. 1974. Vertical gradients of water potential and tissue water relations in Sitka spruce trees measured with the pressure chamber. Journal of Applied Ecology 11: 637-667.

Hendriks CMA, Bianchi FJJA. 1995. Root density and root biomass in pure and mixed forest stands of Douglas fir and beech. Netherlands Journal of Agricultural Science 43: 321-331.

Hertel D. 1999. The fine root system of mixed stands of European beech: structure, dynamics and interspecific competition (In German). Berlin, Germany: Cramer.

Holbrook NM, Zwieniecki MA. 1999. Embolism repair and xylem tension: Do we need a miracle? Plant Physiology 120: 7-10.

Hsiao TC, Xu LK. 2000. Sensitivity of growth of roots versus leaves to water stress: biophysical analysis and relation to water transport. Journal of Experimental Botany 51: 1595-1616.

Huang BR, Nobel PS. 1993. Hydraulic conductivity and anatomy along lateral roots of cacti: changes with soil water status. New Phytologist 123: 499-507.

Huber B. 1956. Die Gefäßleitung. In: Ruhland W, ed. Handbuch der Pflanzenphysiologie, vol. 2. Berlin, Germany: Springer, 541-582.

Ito S, Sakuta K, Gyokusen K. 1995. Distribution of hydraulic resistance in seedlings, sprouts and an adult tree of Pasania edulis MAKINO. Ecological Research 10: 143-149.

Jackson RB, Moore LA, Hoffmann WA, Pockman WT, Linder CR. 1999. Ecosystem rooting depth determined with caves and DNA. Proceedings of the National Academy of Sciences 96: 11387-11392.

Jarbeau JA, Ewers FW, Davis SD. 1995. The mechanism of water-stress induced embolism in two species of Chaparral shrubs. Plant, Cell and Environment 18: 189-196.

Johnson D, Vandenkoornhuyse PJ, Leake JR, Gilbert L, Booth RE, Grime JP, Young JPW, Read DJ. 2004. Plant communities affect arbuscular mycorrhizal fungal diversity and community composition in grassland microcosms. New Phytologist 161: 503-515.

Joslin JD, Wolfe MH, Hanson PJ. 2000. Effects of altered water regimes on forest root systems. New Phytologist 147: 117-129.

Kaldenhoff R, Fischer M. 2006. Aquaporins in plants. Acta Physiologica 187: 169-176. 
Katsuhara M, Shibasaka M. 2007. Barley root hydraulic conductivity and aquaporins expression in relation to salt tolerance. Soil Science and Plant Nutrition 53: 466-470.

Kirch HH, Vera-Estrella R, Golldack D, Quigley F, Michalowski CB, Barkla BJ, Bohnert HJ. 2000. Expression of water channel proteins in Mesembryanthemum crystallinum. Plant Physiology 123: 111-124.

Konôpka B, Yuste JC, Janssens IA, Ceulemans R. 2005. Comparison of fine root dynamics in Scots pine and Pedunculate oak in sandy soil. Plant and Soil 276: 33-45.

Korn S. 2004. Experimental investigation of water uptake and hydraulic properties of the root system of six European tree species (In German). PhD thesis. University of Göttingen, Germany.

Kozlowski TT, Kramer PJ, Pallardy SG. 1991. The physiological ecology of woody plants. San Diego, USA: Academic Press.

Köstler JN, Brückner E, Bibelriether H. 1968. Die Wurzeln der Waldbäume. Berlin, Germany: Parey.

Larcher W. 2001. Ökophysiologie der Pflanzen. $6^{\text {th }}$ ed. Stuttgart, Germany: Ulmer.

Leake JR, Johnson D, Donnelly DP, Muckle GE, Boddy L, Read DJ. 2004. Networks of power and influence: the role of mycorrhizal mycelium in controlling plant communities and agroecosystem functioning. Canadian Journal of Botany 82: 1016-1045.

Leuschner C, Hertel D, Coners H, Büttner V. 2001. Root competition between beech and oak: a hypothesis. Oecologia 126: 276-284.

Leuschner C, Coners H, Icke R, Hartmann K, Effinger ND, Schreiber L. 2003. Chemical composition of the periderm in relation to in situ water absorption rates of oak, beech and spruce fine roots. Annals of Forest Science 60: 763-772.

Leuschner C, Coners H, Icke R. 2004a. In situ measurement of water absorption by fine roots of three temperate trees: species differences and differential activity of superficial and deep roots. Tree Physiology 24: 1359-1367.

Leuschner C, Hertel D, Schmid I, Koch O, Muhs A, Hölscher D. 2004b. Stand fine root biomass and fine root morphology in old-growth beech forests as a function of precipitation and soil fertility. Plant and Soil 258: 43-56.

Leuzinger S, Zotz G, Asshoff R, Körner C. 2005. Responses of deciduous forest trees to severe drought in Central Europe. Tree Physiology 25: 641-650.

Levy Y, Syvertsen JP, Nemec S. 1983. Effect of drought stress and vesicular arbuscular mycorrhiza on citrus transpiration and hydraulic conductivity of roots. New Phytologist 93: 61-66.

Lindenmair J, Matzner E, Zimmermann R. 2004. The role of woody roots in water uptake of mature spruce, beech and oak trees. In: Matzner E, ed. Biogeochemistry of forest catchments in a changing environment. Berlin, Germany: Springer, 279-289.

Lo Gullo MA, Salleo S. 1988. Different strategies of drought resistance in three Mediterranean sclerophyllous trees growing in the same environmental conditions. New Phytologist 108: 267-276.

Lovisolo C, Schubert A. 2006. Mercury hinders recovery of shoot hydraulic conductivity during grapevine rehydration: evidence from a whole-plant approach. New Phytologist 172: 469-478.

Lovisolo C, Secchi F, Nardini A, Salleo S, Buffa R, Schubert A. 2007. Expression of PIP1 and PIP2 aquaporins is enhanced in olive dwarf genotypes and is related to root and leaf hydraulic conductance. Physiologia Plantarum 130: 543-551.

MacFall JS, Johnson GA, Kramer PJ. 1990. Observation of a water-depletion region surrounding Loblolly pine roots by magnetic-resonance-imaging. Proceedings of the National Academy of Sciences 87: 1203-1207.

MacFall JS, Johnson GA, Kramer PJ. 1991. Comparative water-uptake by roots of different ages in seedlings of Loblolly pine (Pinus taeda L.). New Phytologist 119: 551-560.

Magnani F. 2000. Carbon allocation and tree growth under hydraulic constraints in Scots pine (Pinus sylvestris L.). $\mathrm{PhD}$ thesis. University of Edinburgh, UK.

Mainiero R, Kazda M. 2006. Depth-related fine root dynamics of Fagus sylvatica during exceptional drought. Forest Ecology and Management 237: 135-142. 
Matyssek R, Tang AC, Boyer JS. 1991. Plants can grow on internal water. Plant, Cell and Environment 14: $925-930$.

McKay HM, Malcolm DC. 1988. A comparison of the fine root component of a pure and a mixed coniferous stand. Canadian Journal of Forest Research 18: 1416-1426.

McPhee CS. 1998. Investigation of the interaction between root competition and shoot competition in plants. Master thesis. Queens University Kinston, Ontario, Canada.

Meier IC, Leuschner C. 2008a. Genotypic variation and phenotypic plasticity in the drought response of fine roots of European beech. Tree Physiology 28: 297-309.

Meier IC, Leuschner C. 2008b. The belowground drought response of European beech: fine root biomass and carbon partitioning in 14 mature stands across a precipitation gradient. Global Change Biology, in press.

Meinzer FC, Fownes JH, Harrington RA. 1996. Growth indices and stomatal control of transpiration in Acacia koa stands planted at different densities. Tree Physiology 16: 607-615.

Mencuccini M. 2002. Hydraulic constraints in the functional scaling of trees. Tree Physiology 22: $553-565$.

Nardini A, Pitt F. 1999. Drought resistance of Quercus pubescens as a function of root hydraulic conductance, xylem embolism and hydraulic architecture. New Phytologist 143: 485-493.

Nardini A, Salleo S, Tyree MT, Vertovec M. 2000. Influence of the ectomycorrhizas formed by Tuber melanosporum VITT. on hydraulic conductance and water relations of Quercus ilex L. seedlings. Annals of Forest Science 57: 305-312.

North GB, Nobel PS. 1992. Drought induced changes in hydraulic conductivity and structure in roots of Ferocactus acanthodes and Opuntia ficus indica. New Phytologist 120: 9-19.

Oron G, DeMalach Y, Gillerman L, David I, Rao VP. 1999. Improved saline-water use under subsurface drip irrigation. Agricultural Water Management 39: 19-33.

Osunubi O, Davies WJ. 1981. Root growth and water relations of oak and birch seedlings. Oecologia 51: 343-350.

Otto B, Kaldenhoff R. 2000. Cell-specific expression of the mercury-insensitive plasma-membrane aquaporin NtAQP1 from Nicotiana tabacum. Planta 211: 167-172.

Pate JS, Jeschke WD, Aylward MJ. 1995. Hydraulic architecture and xylem structure of the dimorphic root systems of South-West Australian species of Proteaceae. Journal of Experimental Botany 46: 907 915.

Pereira JS, David JS, David TS, Caldeira MC, Chaves MM. 2004. Carbon and water fluxes in Mediterranean-type ecosystems - Constraints and adaptations. In: Esser K, Lüttge U, Beyschlag W, Murata J, eds. Progress in Botany 65. Berlin, Germany: Springer, 468-495.

Pereira JS, Chaves MM, Caldeira MC, Correia A. 2006. Water availability and productivity. In: Morison JIL, Morecroft MD, eds. Plant growth and climate change. Oxford, UK: Blackwell, 118-145.

Pickard WF. 1989. How might a tracheary element which is embolized by day be healed by night. Journal of Theoretical Biology 141: 259-279.

Pockman WT, Sperry JS. 2000. Vulnerability to xylem cavitation and the distribution of Sonoran desert vegetation. American Journal of Botany 87: 1287-1299.

Raftoyannis Y, Radoglou K. 2002. Physiological responses of beech and Sessile oak in a natural mixed stand during a dry summer. Annals of Botany 89: 723-730.

Raven JA, Edwards D. 2001. Roots: evolutionary origins and biogeochemical significance. Journal of Experimental Botany 52: 381-401.

Reich PB, Hinckley TM. 1989. Influence of pre-dawn water potential and soil-to-leaf hydraulic conductance on maximum daily leaf diffusive conductance in two oak species. Functional Ecology 3: 719-726.

Richards JH, Caldwell MM. 1987. Hydraulic lift - Substantial nocturnal water transport between soil layers by Artemisia tridentata roots. Oecologia 73: 486-489. 
Rieger M, Litvin P. 1999. Root system hydraulic conductivity in species with contrasting root anatomy. Journal of Experimental Botany 50: 201-209.

Ryel RJ. 2004. Hydraulic redistribution. In: Esser K, Lüttge U, Beyschlag W, Murata J, eds. Progress in Botany 65. Berlin, Germany: Springer, 413-435.

Sakr S, Alves G, Morillon RL, Maurel K, Decourteix M, Guilliot A, Fleurat-Lessard P, Julien JL, Chrispeels MJ. 2003. Plasma membrane aquaporins are involved in winter embolism recovery in walnut tree. Plant Physiology 133: 630-641.

Sands R, Fiscus EL, Reid CPP. 1982. Hydraulic-properties of pine and bean roots with varying degrees of suberization, vascular differentiation and mycorrhizal infection. Australian Journal of Plant Physiology 9: 559-569.

Schäffner AR. 1998. Aquaporin function, structure, and expression: are there more surprises to surface in water relations? Planta 204: 131-139.

Schmid I, Kazda M. 2002. Root distribution of Norway spruce in monospecific and mixed stands on different soils. Forest Ecology and Management 159: 37-47.

Schreiber L, Franke R, Hartmann KD, Ranathunge K, Steudle E. 2005. The chemical composition of suberin in apoplastic barriers affects radial hydraulic conductivity differently in the roots of rice (Oryza sativa L. cv. IR64) and corn (Zea mays L. cv. Helix). Journal of Experimental Botany 56: 1427-1436.

Schulze ED, Caldwell MM, Canadell J, Mooney HA, Jackson RB, Parson D, Scholes R, Sala OE, Trimborn P. 1998. Downward flux of water through roots (i.e. inverse hydraulic lift) in dry Kalahari sands. Oecologia 115: 460-462.

Seyfried MS, Schwinning S, Walvoord MA, Pockman WT, Newman BD, Jackson RB, Phillips EM. 2005. Ecohydrological control of deep drainage in arid and semiarid regions. Ecology 86: 277-287.

Shani U, Waisel Y, Eshel A, Xue S, Ziv G. 1993. Responses to salinity of grapevine plants with split root systems. New Phytologist 124: 695-701.

Shi LB, Guttenberger M, Kottke I, Hampp R. 2002. The effect of drought on mycorrhizas of beech (Fagus sylvatica L.): changes in community structure, and the content of carbohydrates and nitrogen storage bodies of the fungi. Mycorrhiza 12: 303-311.

Silberbush M, Barber SA. 1983. Sensitivity analysis of parameters used in simulating K uptake with a mechanistic mathematical model. Agronomy Journal 75: 851-854.

Sperry JS, Tyree MT. 1988. Mechanism of water stress-induced xylem embolism. Plant Physiology 88: 581-587.

Sperry JS, Saliendra NZ. 1994. Intra- and inter-plant variation in xylem cavitation in Betula occidentalis. Plant, Cell and Environment 17: 1233-1241.

Sperry JS, Ikeda T. 1997. Xylem cavitation in roots and stems of Douglas fir and White fir. Tree Physiology 17: 275-280.

Staelens J, De Schrijver A, Verheyen K, Verhoest NEC. 2006. Spatial variability and temporal stability of throughfall water under a dominant beech (Fagus sylvatica L.) tree in relationship to canopy cover. Journal of Hydrology 330: 651-662.

Staubin G, Canny MJ, McCully ME. 1986. Living vessel elements in the late metaxylem of sheathed maize roots. Annals of Botany 58: 577-588.

Steudle E. 1994. Water transport across roots. Plant and Soil 167: 79-90.

Steudle E, Heydt H. 1997. Water transport across tree roots. In: Rennenberg H, Eschrich W, Ziegler H, eds. Trees - Contributions to modern tree physiology. Leiden, The Netherlands: Backhuys, 239-255.

Steudle E. 2000. Water uptake by roots: effects of water deficit. Journal of Experimental Botany 51: 1531-1542.

Trillo N, Fernández R. 2005. Wheat plant hydraulic properties under prolonged experimental drought: Stronger decline in root-system conductance than in leaf area. Plant and Soil 277: 277-284.

Tyree MT, Fiscus EL, Wullschleger SD, Dixon MA. 1986. Detection of xylem cavitation in corn under field conditions. Plant Physiology 82: 597-599. 
Tyree MT. 1997. The Cohesion-Tension theory of sap ascent: current controversies. Journal of Experimental Botany 48: 1753-1765.

Tyree MT. 2003. The ascent of water. Nature 423: 923.

Tyree MT, Zimmermann MH. 2003. Xylem structure and the ascent of sap. Stuttgart, Germany: Springer.

Vanninen P, Ylitalo H, Sievanen R, Mäkelä A. 1996. Effects of age and site quality on the distribution of biomass in Scots pine (Pinus sylvestris L.). Trees - Structure and Function 10: 231-238.

Vercambre G, Doussan C, Pagès L, Habib R, Pierret A. 2002. Influence of xylem development on axial hydraulic conductance within Prunus root systems. Trees - Structure and Function 16: 479-487.

Weissbein S. 2006. Characterization of new olive (Olea europea L.) varieties response to irrigation with saline water in the Ramat Negev area. Master thesis. Ben-Gurion University of the Negev, Israel.

West GB, Brown JH, Enquist BJ. 1999. A general model for the structure and allometry of plant vascular systems. Nature 400: 664-667.

Yamada S, Komori T, Myers PN, Kuwata S, Kubo T, Imaseki H. 1997. Expression of plasma membrane water channel genes under water stress in Nicotiana excelsior. Plant and Cell Physiology 38: 1226-1231.

Zimmermann HM, Steudle E. 1998. Apoplastic transport across young maize roots: effect of the exodermis. Planta 206: 7-19.

Zimmermann MH. 1983. Xylem structure and the ascent of sap. Berlin, Germany: Springer.

Zobel RW. 1991. Genetic control of root systems. In: Waisel Y, Eshel A, Kafkafi U, eds. Plant root systems. New York, USA: Marcel Dekker, 27-38.

Zwieniecki MA, Holbrook NM. 1998. Diurnal variation in xylem hydraulic conductivity in White ash (Fraxinus americana L.), Red maple (Acer rubrum L.) and Red spruce (Picea rubens SARG.). Plant, Cell and Environment 21: 1173-1180. 



\section{ANNEX}

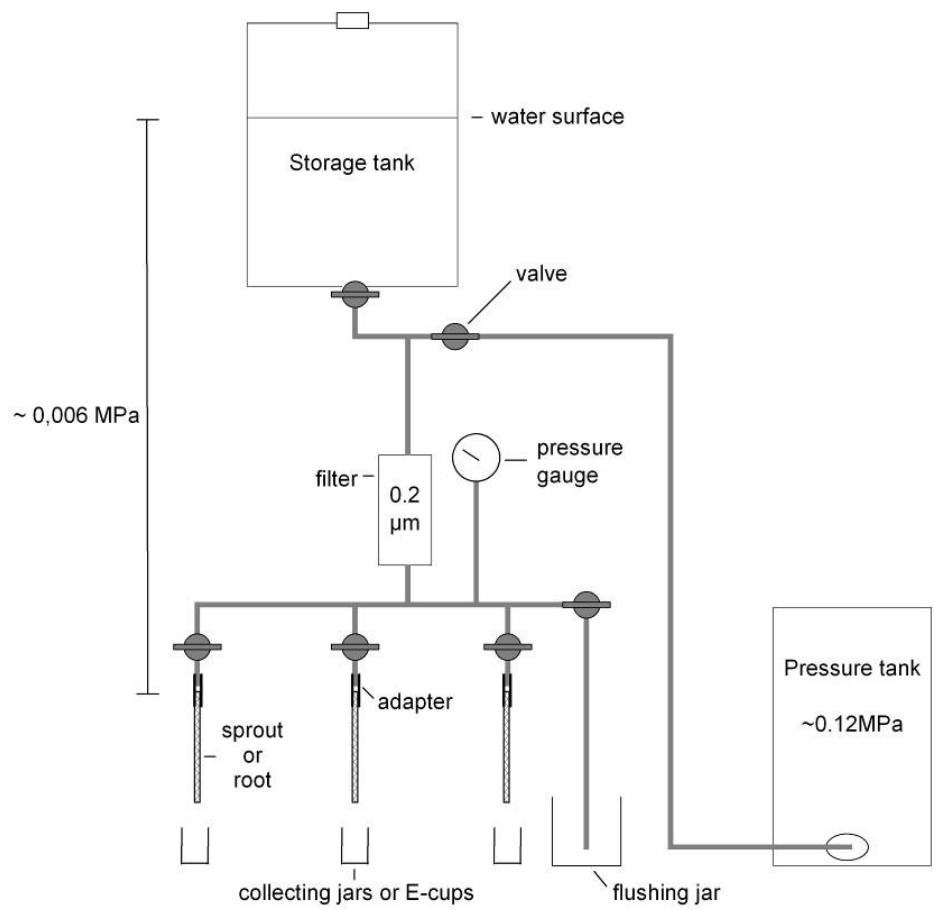

Fig. A 1 Apparatus for measurement of axial hydraulic conductivity and the degree of embolism according to the protocol given by Sperry et al. (1988). This method was used in Chapters 2 and 3.

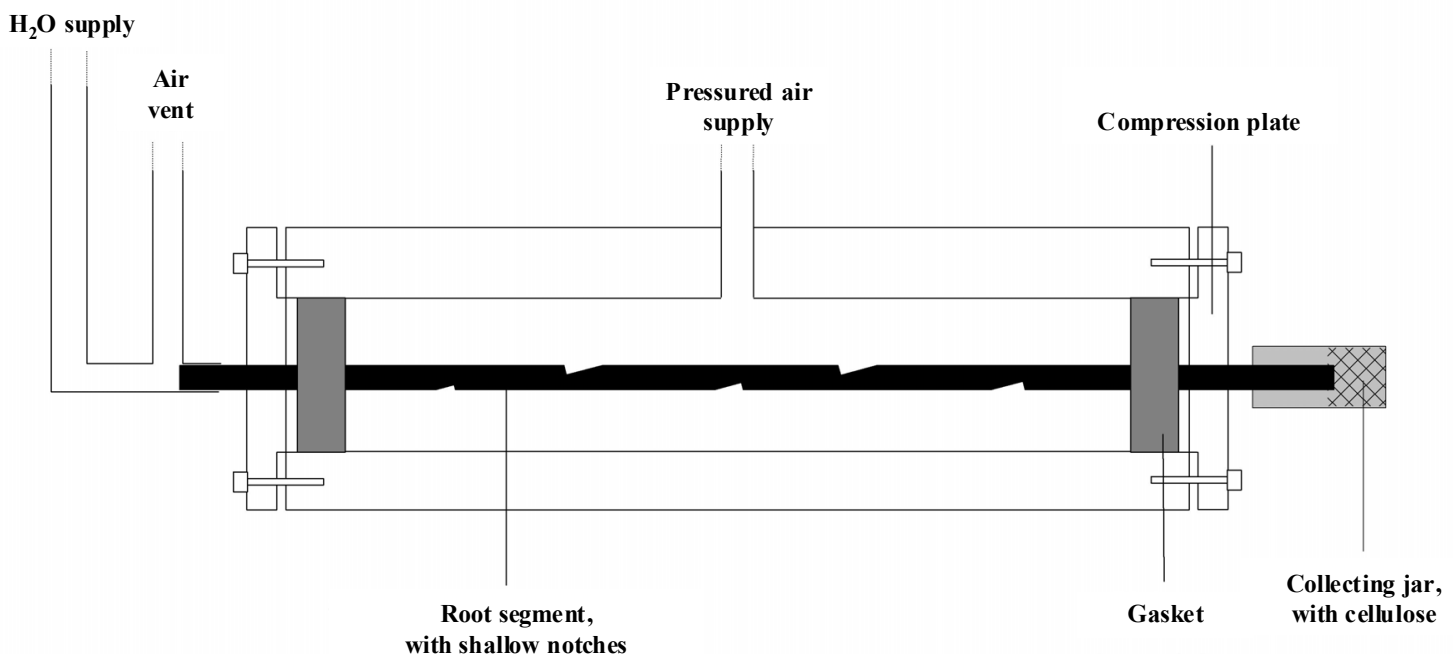

Fig. A 2 Apparatus to determine the vulnerability to embolism with the 'air injection method' according to the protocol given by Sperry and Saliendra (1994). This method was used in Chapter 2. 


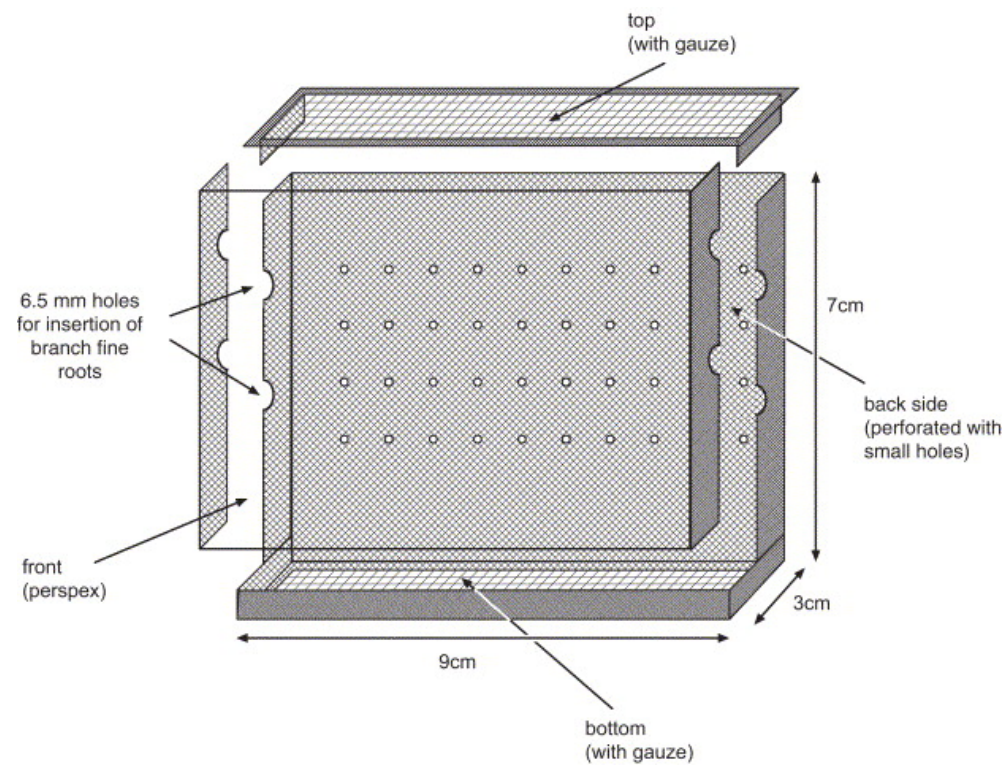

Fig. A 3 The in situ-root growth chamber as used for the assessment of competition belowground in Chapters 4 and 5. Reprinted from Hertel and Leuschner (2006).
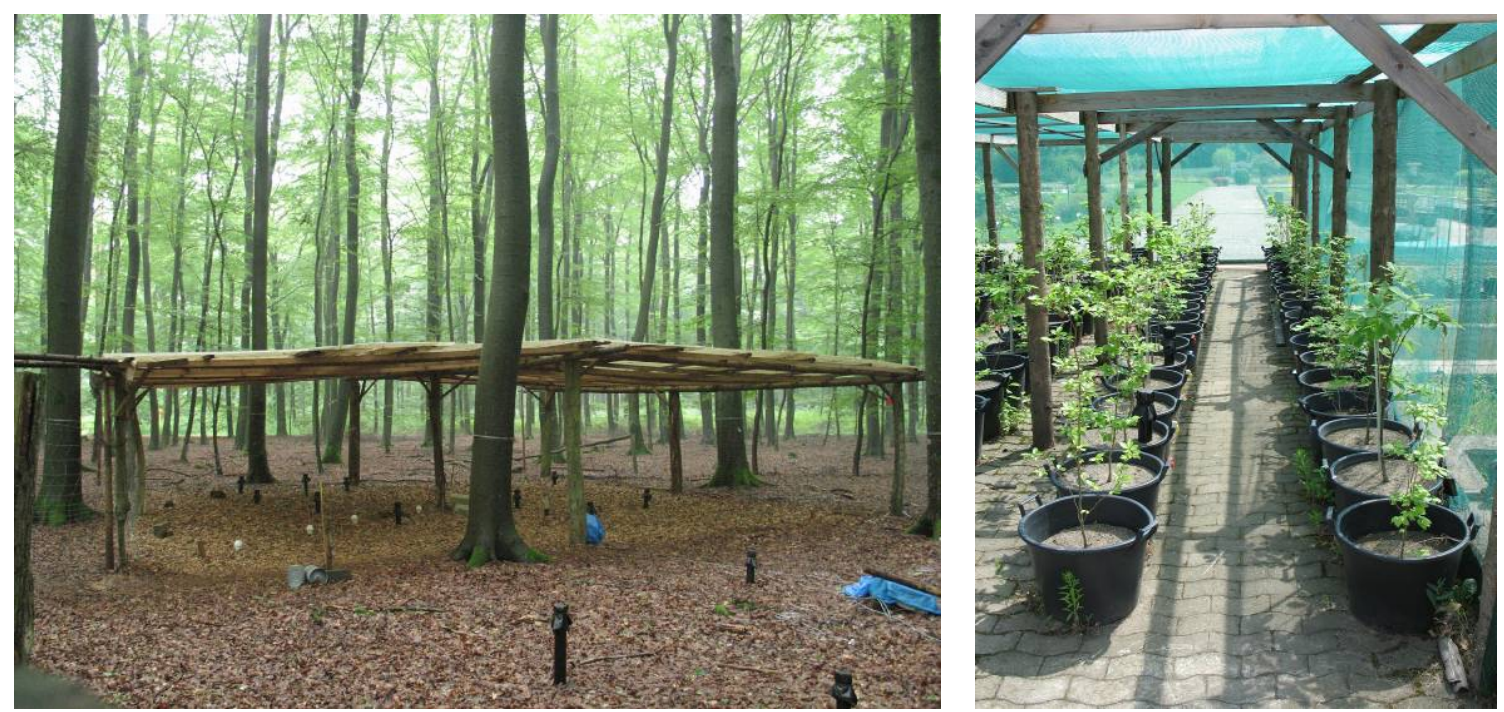

Fig. A 4 The experimental sites: Sub-canopy roof in a beech patch of the Unterlüß forest, Lower-Saxony, Germany (left), and the saplings experiment at the Experimental Botanical Garden, University of Göttingen, Germany (right). 


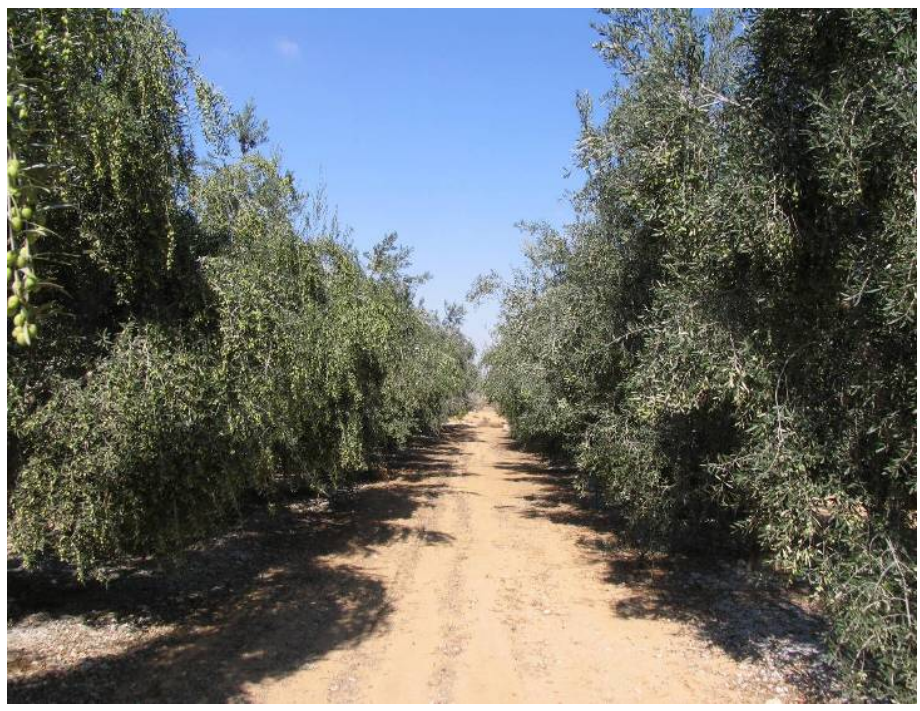

Fig. A 5 The experimental sites: Olive orchard at the Ramat Negev Experimental Station, South Israel.

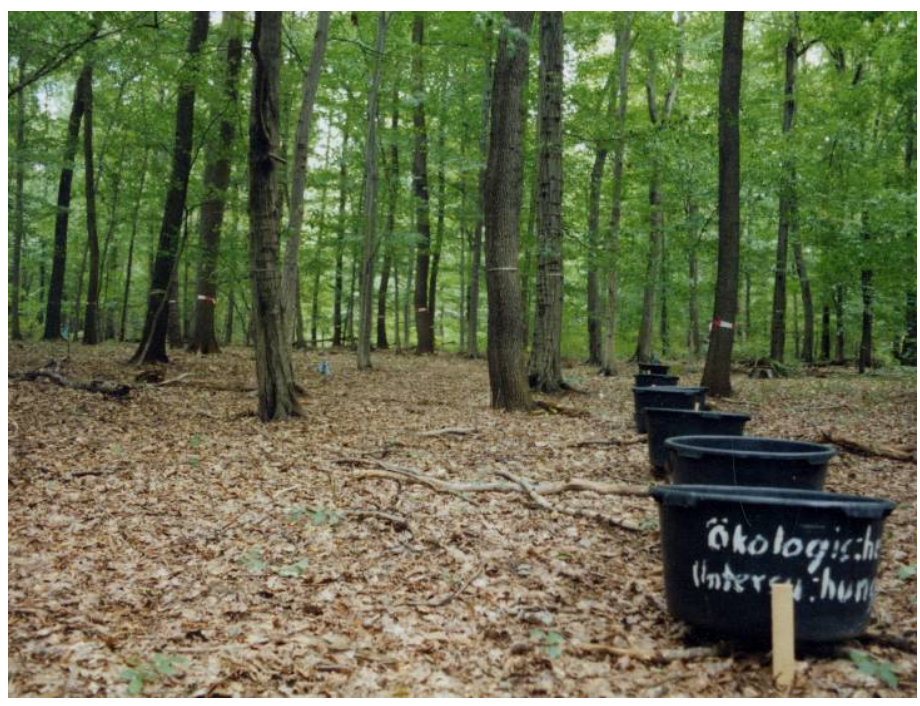

Fig. A 6 The experimental sites: Mixed stand in the Ziegelrodaer forest, Saxony-Anhalt, Germany. 
Table A 1 Effect of drought or salinity on root biomass, root:shoot ratio (or root:leaf ratio), rooting depth and fine root turnover in seedlings, compared to well-watered treatments.

\begin{tabular}{|c|c|c|c|c|c|c|}
\hline Species & $\begin{array}{l}\text { Duration, } \\
\text { method, } \\
\text { stress* }\end{array}$ & $\begin{array}{l}\text { Root } \\
\text { bio- } \\
\text { mass }\end{array}$ & $\begin{array}{l}\text { Root: } \\
\text { shoot } \\
\text { ratio }\end{array}$ & $\begin{array}{l}\text { Root } \\
\text { depth }\end{array}$ & $\begin{array}{l}\text { Fine } \\
\text { root } \\
\text { turn- } \\
\text { over }\end{array}$ & Reference \\
\hline $\begin{array}{l}\text { Quercus robur } \\
\text { Betula pendula }\end{array}$ & pot, d & $\begin{array}{l}+ \\
\mathrm{ns}\end{array}$ & ns & $\begin{array}{l}++ \\
\text { ns }\end{array}$ & & Osunubi and Davies 1981 \\
\hline Pinus taeda & pot, d & ns & ++ & & & Bongarten and Tesky 1987 \\
\hline Fagus sylvatica & 12-wk, pot, d & -- & & & & Davidson et al. 1992 \\
\hline $\begin{array}{l}\text { Juglans nigra } \\
\text { Quercus stellata } \\
\text { Quercus alba } \\
\text { Acer saccharum }\end{array}$ & pot, d & $\begin{array}{l}\mathrm{ns} \\
\mathrm{ns} \\
\mathrm{ns} \\
\mathrm{ns}\end{array}$ & ++ & & & Pallardy and Rhoads 1993 \\
\hline Quercus robur & 3-wk, pot, d & -- & ns & & & Fort et al. 1997 \\
\hline Betula pendula & 2-wk, pot, d & -- & - & & & Fort et al. 1998 \\
\hline Picea abies $\mathrm{M}$ clone & 8-wk, pot, d & -- & & & & Karlsson et al. 1997 \\
\hline $\begin{array}{l}\text { Fagus sylvatica } \\
\text { Quercus petraea }\end{array}$ & pot, d & $\begin{array}{l}\mathrm{ns} \\
\mathrm{ns}\end{array}$ & $\begin{array}{l}++ \\
+\end{array}$ & & & Van Hees 1997 \\
\hline Quercus rubra & 12-wk, pot, d & ns & ++ & & & Tomlinson and Anderson 1998 \\
\hline Pinus taeda & 4-wk, pot, d & ns & ns & + & & Torreano and Morris 1998 \\
\hline Fagus sylvatica & 12-wk, exp, d & & - & & & Volkmer and Rennenberg 1999 \\
\hline $\begin{array}{l}\text { Fagus sylvatica } \\
\text { Quercus petraea } \\
\text { Quercus pubescens } \\
\text { Sorbus aria }\end{array}$ & $\begin{array}{l}2 \times 10 / 11-w k \\
\text { pot, d }\end{array}$ & $\begin{array}{l}- \\
++ \\
\mathrm{ns} \\
\mathrm{ns}\end{array}$ & $\begin{array}{l}0 \\
++ \\
+ \\
+\end{array}$ & & & Thomas 2000 \\
\hline $\begin{array}{l}\text { Quercus robur } \\
\text { Quercus petraea }\end{array}$ & 14-wk, pot, d & $\begin{array}{l}\text { ns } \\
\text { ns }\end{array}$ & $\begin{array}{l}++ \\
++\end{array}$ & $\begin{array}{l}\text { ns } \\
\text { ns }\end{array}$ & & Thomas and Gausling 2000 \\
\hline Fagus sylvatica & 7-wk, pot, d & & -- & & & Fotelli et al. 2001 \\
\hline Prunus dulcis & 1-4-yr, pot, d & ns & ns & & & Heilmeier et al. 2001 \\
\hline $\begin{array}{l}\text { Quercus robur } \\
\text { Quercus petraea }\end{array}$ & 8-wk, pot, d & $\begin{array}{l}\mathrm{ns} \\
\mathrm{ns}\end{array}$ & $\begin{array}{l}++ \\
++\end{array}$ & & & $\begin{array}{l}\text { Gieger 2002, Gieger and Tho- } \\
\text { mas } 2002\end{array}$ \\
\hline Thuja occidentalis & 2-yr, exp, d & - & -- & & ns & Pronk et al. 2002 \\
\hline Quercus ilex & 12-wk, pot, d & -- & + & & + & Chiatante et al. 2005 \\
\hline Fagus sylvatica & pot, d & ns & ++ & & & Löf et al. 2005 \\
\hline $\begin{array}{l}\text { Prosopis argentina } \\
\text { Prosopis alpataco }\end{array}$ & 12-wk, pot, s & $\begin{array}{l}-- \\
-\end{array}$ & $\begin{array}{l}+/- \\
+/-\end{array}$ & & & Villagra et al. 2005 \\
\hline $\begin{array}{l}\text { Prosopis argentina } \\
\text { Prosopis alpataco }\end{array}$ & 12-wk, pot, d & - & $\begin{array}{l}++ \\
++\end{array}$ & & & Villagra et al. 2006 \\
\hline Betula pendula & $\begin{array}{l}\text { 12-14-wk, } \\
\text { pot, d }\end{array}$ & -- & ++ & & & Aspelmeier and Leuschner 2006 \\
\hline $\begin{array}{l}\text { Quercus pubescens } \\
\text { Fraxinus ornus }\end{array}$ & 12-wk, pot, d & $\begin{array}{l}-- \\
--\end{array}$ & $\begin{array}{l}\text { ns } \\
+\end{array}$ & $\begin{array}{l}- \\
--\end{array}$ & $\begin{array}{l}+ \\
+\end{array}$ & Chiatante et al. 2006 \\
\hline $\begin{array}{l}\text { Pinus canadiensis } \mathrm{SH}^{*} \\
\text { Pinus canadiensis } \mathrm{FL}\end{array}$ & $22 w k$, pot, d & $\begin{array}{l}++ \\
\text { ns }\end{array}$ & $\begin{array}{l}++ \\
\text { ns }\end{array}$ & & & Climent et al. 2006 \\
\hline $\begin{array}{l}\text { Fagus sylvatica } \\
\text { Fraxinus excelsior } \\
\text { Quercus petraea }\end{array}$ & 12-wk, pot, d & $\begin{array}{l}-- \\
-- \\
--\end{array}$ & & & & Schumann 2006 \\
\hline Fagus sylvatica var.* & 12-wk, pot, d & -- & & ns & & Rose 2007 \\
\hline Pistacia lentiscus & 24-wk, pot, d & -- & -- & & ns & Cortina et al. 2008 \\
\hline Fagus sylvatica var.* & 2-yr, pot, d & $-/--$ & $+/ \mathrm{ns}$ & - & & Meier and Leuschner 2008a \\
\hline $\begin{array}{l}\text { Fagus sylvatica } \\
\text { Quercus petraea }\end{array}$ & 3 -yr, pot, d & $\begin{array}{l}-- \\
--\end{array}$ & $\begin{array}{l}- \\
-\end{array}$ & & & This study (Fig. 6.1) \\
\hline
\end{tabular}

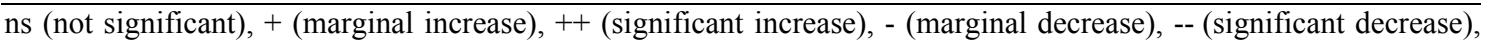
+/- or -/-- (data not consistent); * pot (pot experiment), exp (in situ experiment), d (drought), s (salt); SH (shaded), FL (full light), var. (different varieties). 
Table A 2 Effect of drought or salinity on root biomass, root:shoot ratio (or root:leaf ratio), rooting depth and fine root turnover in stands or orchards of mature trees, compared to well-watered sites or treatments.

\begin{tabular}{|c|c|c|c|c|c|c|}
\hline Dominant species & $\begin{array}{l}\text { Duration, } \\
\text { method, } \\
\text { stress* }\end{array}$ & $\begin{array}{l}\text { Root } \\
\text { bio- } \\
\text { mass }\end{array}$ & $\begin{array}{l}\text { Root: } \\
\text { shoot } \\
\text { ratio }\end{array}$ & $\begin{array}{l}\text { Root } \\
\text { depth }\end{array}$ & $\begin{array}{l}\text { Fine } \\
\text { root } \\
\text { turn- } \\
\text { over }\end{array}$ & Reference \\
\hline Pseudotsuga menziesii & grad, d & ns & & & + & Santantonio and Hermann 1985 \\
\hline $\begin{array}{l}\text { Fagus sylvatica } \\
\text { Quercus rubra } \\
\text { Carya spp. } \\
\text { Liriodendron tulipifera }\end{array}$ & grad, d & -- & & & & Kalisz et al. 1987 \\
\hline Pinus contorta & grad, d & & + & & + & Comeau and Kimmins 1989 \\
\hline Pseudotsuga menziesii & 2-yr, exp, d & ++ & ++ & & ++ & Gower et al. 1992 \\
\hline $\begin{array}{l}\text { Picea abies } \\
\text { Pseudotsuga menziesii }\end{array}$ & 3-4-yr, exp, d & $\begin{array}{l}+ \\
+\end{array}$ & $\begin{array}{l}+ \\
\mathrm{ns}\end{array}$ & & $\begin{array}{l}+ \\
+\end{array}$ & de Visser et al. 1994 \\
\hline Populus deltoides & 4-yr, exp, d & ns & & ++ & & Dickmann et al. 1996 \\
\hline Pinus taeda & grad, d & ++ & & & & Parker and Lear 1996 \\
\hline Picea abies & 3-yr, exp, d & ns & ns & & ns & Bredemeier et al. 1998 \\
\hline Hevea brasiliensis & 10-yr, exp, d & ns & ++ & -- & & Devakumar et al. 1999 \\
\hline $\begin{array}{l}\text { Pinus sylvestris } \\
\text { Picea abies }\end{array}$ & grad, d & ns & & & + & Pietikäinen et al. 1999 \\
\hline $\begin{array}{l}\text { Quercus prinus } \\
\text { Quercus alba } \\
\text { Nyssa sylvatica } \\
\text { Acer rubrum }\end{array}$ & $5-y r, \exp , \mathrm{d}$ & ns & ns & & ns & Joslin et al. 2000 \\
\hline $\begin{array}{l}\text { Fagus sylvatica } \\
\text { Quercus petraea }\end{array}$ & grad, d & -- & & & & Leuschner and Hertel 2003 \\
\hline Fagus sylvatica & grad, d & - & & & & Leuschner et al. 2004 \\
\hline $\begin{array}{l}\text { Fagus sylvatica } \\
\text { Quercus petraea }\end{array}$ & 12-wk, exp, d & $\begin{array}{l}- \\
--\end{array}$ & & & & $\begin{array}{l}\text { Prigge 2005, this study } \\
\text { (Fig. 6.2) }\end{array}$ \\
\hline Olea europea & $1-y r, \exp , \mathrm{s}$ & - & & & + & Weissbein 2006 \\
\hline Cryptomera japonica & 24-wk, exp, d & -- & & & - & Konôpka et al. 2007 \\
\hline Fagus sylvatica & grad, d & -- & & & & Meier and Leuschner 2008b \\
\hline $\begin{array}{l}\text { Fagus sylvatica } \\
\text { Quercus petraea }\end{array}$ & 2-yr, exp, d & $\begin{array}{l}- \\
--\end{array}$ & & & & This study (data not shown) \\
\hline
\end{tabular}

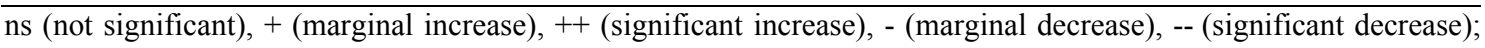
*exp (in situ experiment), grad (moisture gradient), d (drought), s (salt). 
Table A 3 Studies on herbaceous plants suggesting either symmetric or asymmetric competition belowground.

\begin{tabular}{|c|c|c|c|c|}
\hline Species & $\begin{array}{l}\text { Type } \\
\text { of study* }\end{array}$ & $\begin{array}{l}\text { Main } \\
\text { evidence }^{\dagger}\end{array}$ & Rationale & Reference \\
\hline $\begin{array}{l}\text { Plantago lanceolata } \\
\text { Holcus lanatus } \\
\text { Lolium perenne } \\
\text { Rumex acetosa }\end{array}$ & pot & asym & $\begin{array}{l}\text { competitive advantage of } \\
\text { smaller plants, species } \\
\text { identity important de- } \\
\text { terminant }\end{array}$ & $\begin{array}{l}\text { Newbery and Newman } \\
1978\end{array}$ \\
\hline Lolium perenne & pot & sym & $\begin{array}{l}\text { root biomass; } \\
\text { high root:shoot ratio }\end{array}$ & $\begin{array}{l}\text { Hofman and Ennik 1980, } \\
\text { 1982, Ennik and Hofman } \\
1983\end{array}$ \\
\hline $\begin{array}{l}\text { Agropyron spicatum } \\
\text { Agropyron desertorum }\end{array}$ & pot & asym & $\begin{array}{l}\text { differences in phospho- } \\
\text { rus competition in simi- } \\
\text { lar-sized plants }\end{array}$ & Caldwell et al. 1985 \\
\hline Ipomoea tricolor & pot & sym & $\begin{array}{l}\text { growth rates, size asym- } \\
\text { metry }\end{array}$ & Weiner 1986 \\
\hline $\begin{array}{l}\text { Agrostis stolonifera } \\
\text { Scirpus sylvaticus }\end{array}$ & in situ & asym & $\begin{array}{l}\text { nitrogen capture was not } \\
\text { related to root system } \\
\text { size }\end{array}$ & Crick and Grime 1987 \\
\hline $\begin{array}{l}\text { Solidago canadensis } \\
\text { Div. (old-field) }\end{array}$ & in situ & sym & $\begin{array}{l}\text { per-unit-size effects; lack } \\
\text { of species effect }\end{array}$ & Goldberg 1987 \\
\hline Div. (7 species) & in situ & sym & $\begin{array}{l}\text { per-gram effect stronger } \\
\text { than per-individual } \\
\text { effects }\end{array}$ & Miller and Werner 1987 \\
\hline Festuca ovina & pot & asym & $\begin{array}{l}\text { no effect of initial size } \\
\text { advantage }\end{array}$ & Wilson 1988 \\
\hline $\begin{array}{l}\text { Ambrosia artemisiifolia } \\
\text { Impatiens pallida }\end{array}$ & in situ & $\begin{array}{l}\text { sym / } \\
\text { asym }\end{array}$ & low root biomass & Thomas and Weiner 1989 \\
\hline Molina caerulea & pot & $\begin{array}{l}\text { sym / } \\
\text { asym }\end{array}$ & $\begin{array}{l}\text { root biomass; } \\
\text { high root:shoot ratio, } \\
\text { root proliferation }\end{array}$ & Aerts et al. 1991 \\
\hline Div. (8 species) & pot & asym & $\begin{array}{l}\text { species specific foraging } \\
\text { mechanism (scale vs. } \\
\text { precision) }\end{array}$ & Campbell et al. 1991a, b \\
\hline $\begin{array}{l}\text { Div. ( } 7 \text { species, old-field } \\
\text { and pasture) }\end{array}$ & in situ & sym & $\begin{array}{l}\text { per-gram effect stronger } \\
\text { than per-individual } \\
\text { effects }\end{array}$ & Goldberg and Landa 1991 \\
\hline $\begin{array}{l}\text { Agropyron cristatum } \\
\text { Bouteloua gracilis } \\
\text { Elaeagnus commutata } \\
\text { Melilotus offcinalis } \\
\text { Potentilla pensylvanica }\end{array}$ & in situ & asym & $\begin{array}{l}\text { no influence of initial } \\
\text { biomass, species identity } \\
\text { important determinant }\end{array}$ & Gerry and Wilson 1995 \\
\hline Pennisetum americanum & in situ & sym & growth rates & Schwinning 1996 \\
\hline Amaranthus retroflexus & pot & sym & relative growth rates & Cahill 1997 \\
\hline Kochia scoparia & pot & sym & biomass & Weiner et al. 1997 \\
\hline Abutilon theophrasti & pot & sym & growth rates, biomass & Casper et al. 1998 \\
\hline $\begin{array}{l}\text { Anthoxynthum odoratum } \\
\text { Festuca rubra } \\
\text { Holcus lanatus } \\
\text { Lolium perenne }\end{array}$ & pot & asym & $\begin{array}{l}\text { increased } \mathrm{N} \text { uptake per } \\
\text { biomass in heterogene- } \\
\text { ous soils; foraging char- } \\
\text { acteristics }\end{array}$ & Fransen et al. 1998, 1999 \\
\hline $\begin{array}{l}\text { Div. (6 species, South } \\
\text { Carolina costal plain) }\end{array}$ & pot & asym & $\begin{array}{l}\text { Species specific foraging } \\
\text { scale and precision }\end{array}$ & Einsmann et al. 1999 \\
\hline $\begin{array}{l}\text { Div. ( } 7 \text { species, British } \\
\text { woodland) }\end{array}$ & in situ & asym & $\begin{array}{l}\text { differing abilities to } \\
\text { locate and recognize } \\
\text { patches of nutrients }\end{array}$ & Farley and Fitter 1999a,b \\
\hline
\end{tabular}

*in situ (field experiment), pot (pot experiment); ${ }^{\dagger}$ asym (asymmetric competition), sym (symmetric competition). 
Table A 3 (continuation) Studies on herbaceous plants suggesting either symmetric or asymmetric competition belowground.

\begin{tabular}{|c|c|c|c|c|}
\hline Species & $\begin{array}{l}\text { Type } \\
\text { of study* }\end{array}$ & $\begin{array}{l}\text { Main } \\
\text { evidence }^{\dagger}\end{array}$ & Rationale & Reference \\
\hline $\begin{array}{l}\text { Lolium perenne } \\
\text { Poa pratensis }\end{array}$ & pot & asym & $\begin{array}{l}\text { root proliferation in } \\
\text { heterogeneous environ- } \\
\text { ments }\end{array}$ & Hodge et al. 1999a,b \\
\hline $\begin{array}{l}\text { Lolium perenne } \\
\text { Poa pratensis }\end{array}$ & pot & asym & $\begin{array}{l}\text { root proliferation in } \\
\text { heterogeneous environ- } \\
\text { ments }\end{array}$ & Robinson et al. 1999 \\
\hline Amaranthus retroflexus & in situ & sym & $\begin{array}{l}\text { root biomass, no effect } \\
\text { of soil heterogeneity }\end{array}$ & $\begin{array}{l}\text { Cahill 1999, Cahill and } \\
\text { Casper } 2000\end{array}$ \\
\hline Ipomea tricolour & pot & sym & $\begin{array}{l}\text { no influence of hetero- } \\
\text { geneous resources }\end{array}$ & Blair 2001 \\
\hline $\begin{array}{l}\text { Anthoxanthurn odoraturn } \\
\text { Festuca rubra } \\
\text { Holcus lanatus }\end{array}$ & pot & $\begin{array}{l}\text { sym / } \\
\text { asym }\end{array}$ & $\begin{array}{l}\text { biomass production } \\
\text { (homogeneous / hetero- } \\
\text { geneous soil) }\end{array}$ & $\begin{array}{l}\text { Fransen et al. 2001, Fransen } \\
\text { and de Kroon } 2001\end{array}$ \\
\hline $\begin{array}{l}\text { Div. ( } 59 \text { species, Great } \\
\text { Plains grassland)s }\end{array}$ & in situ & asym & $\begin{array}{l}\text { species-specific nutrient } \\
\text { foraging }\end{array}$ & Johnson and Biondini 2001 \\
\hline Div. (6 species) & pot & asym & $\begin{array}{l}\text { no correlation between } \\
\text { root system size and } \\
\text { foraging precision }\end{array}$ & Wijesinghe et al. 2001 \\
\hline $\begin{array}{l}\text { Chaemaecrista nictitans } \\
\text { Hypericum gantianoides } \\
\text { Erechtites hieracifolia } \\
\text { Solidago altissima }\end{array}$ & pot & asym & $\begin{array}{l}\text { foraging scale, precision } \\
\text { and rate in heterogene- } \\
\text { ous environments }\end{array}$ & Bliss et al. 2002 \\
\hline Trifolium subterraneum & pot & asym & $\begin{array}{l}\text { mycorrhizal infection } \\
\text { promotes pre-emption of } \\
\text { heterogeneous resources }\end{array}$ & Facelli and Facelli 2002 \\
\hline Phaseolus varigaris & pot & sym & $\begin{array}{l}\text { higher root biomass } \\
\text { under interspecific com- } \\
\text { petition than in monocul- } \\
\text { ture }\end{array}$ & Maina et al. 2002 \\
\hline Div. (grassland) & in situ & sym & $\begin{array}{l}\text { competition is independ- } \\
\text { ent of species diversity }\end{array}$ & Cahill 2003 \\
\hline $\begin{array}{l}\text { Briza media } \\
\text { Festuca ovina }\end{array}$ & pot & asym & $\begin{array}{l}\text { outcome of two-species } \\
\text { competition may differ } \\
\text { between patchy and } \\
\text { homogeneous soils, } \\
\text { foraging }\end{array}$ & Day et al. 2003 \\
\hline $\begin{array}{l}\text { Lolium perenne } \\
\text { Plantago lanceolata } \\
\text { Trifolium repens }\end{array}$ & pot & asym & $\begin{array}{l}\text { foraging for patchy } \\
\text { resources, uptake kinet- } \\
\text { ics }\end{array}$ & Hodge 2003 \\
\hline $\begin{array}{l}\text { Achillea millefolium } \\
\text { Bromus inermis } \\
\text { Hieracium caespitosum }\end{array}$ & pot & asym & $\begin{array}{l}\text { relative growth rates, } \\
\text { foraging for patchy } \\
\text { resources }\end{array}$ & Rajaniemi 2003 \\
\hline Triticum aestivum & pot & sym & $\begin{array}{l}\text { no pre-emption of re- } \\
\text { sources by larger plants }\end{array}$ & $\begin{array}{l}\text { von Wettberg and Weiner } \\
2003\end{array}$ \\
\hline Div. (8 species) & pot & asym & $\begin{array}{l}\text { foraging scale, precision } \\
\text { and rate; relative growth } \\
\text { rate }\end{array}$ & $\begin{array}{l}\text { Rajaniemi and Reynolds } \\
2004\end{array}$ \\
\hline $\begin{array}{l}\text { Andropogon gerardii } \\
\text { Schizachyrium scoparium } \\
\text { Sorgastrum mutans } \\
\text { Sporobolus heterolepis }\end{array}$ & in situ & asym & $\begin{array}{l}\text { influence of mycorrhiza- } \\
\text { tion on plant-plant inter- } \\
\text { actions }\end{array}$ & Casper and Castelli 2007 \\
\hline Div. (6 species) & in situ & asym & $\begin{array}{l}\text { foraging scale and pre- } \\
\text { cission in patchy soils }\end{array}$ & Rajaniemi 2007 \\
\hline
\end{tabular}


Table A 4 Studies on woody plants suggesting either symmetric or asymmetric competition belowground.

\begin{tabular}{|c|c|c|c|c|}
\hline Species & $\begin{array}{l}\text { Type } \\
\text { of study* }\end{array}$ & $\begin{array}{l}\text { Main } \\
\text { evidence }^{\dagger}\end{array}$ & Rationale & Reference \\
\hline Artemisia tridentata & pot & asym & $\begin{array}{l}\text { differences in phospho- } \\
\text { rus competition in simi- } \\
\text { lar-sized plants }\end{array}$ & Caldwell et al. 1985 \\
\hline $\begin{array}{l}\text { Erica tetralix } \\
\text { Calluna vukgaris }\end{array}$ & pot & asym & $\begin{array}{l}\text { spatial arrangement, } \\
\text { phenotypic plasticity }\end{array}$ & Aerts et al. 1991 \\
\hline Fraxinus pennsylvanica & in situ & asym & $\begin{array}{l}\text { no influence of initial } \\
\text { biomass, species identity } \\
\text { important determinant }\end{array}$ & Gerry and Wilson 1995 \\
\hline $\begin{array}{l}\text { Acer rubrum } \\
\text { Div. }\end{array}$ & $\begin{array}{l}\text { in situ / } \\
\text { pot }\end{array}$ & asym & $\begin{array}{l}\text { genomic difference in } \\
\text { the nutrient uptake kinet- } \\
\text { ics }\end{array}$ & Kelly et al. 1994, 2000 \\
\hline Pinus taeda & in situ & sym & root distribution & Mou et al. 1995 \\
\hline $\begin{array}{l}\text { Diospyrus virginiana } \\
\text { Euonymus americanus } \\
\text { Liquidambar styraciflua } \\
\text { Pinus taeda }\end{array}$ & pot & asym & $\begin{array}{l}\text { Species specific foraging } \\
\text { scale and precision }\end{array}$ & Einsmann et al. 1999 \\
\hline $\begin{array}{l}\text { Fagus sylvatica } \\
\text { Quercus petraea }\end{array}$ & in situ & asym & growth rate, biomass & Hertel 1999 \\
\hline $\begin{array}{l}\text { Grevilla robusta } \\
\text { Senna spectabilis }\end{array}$ & in situ & asym & morphological plasticity & Livesley et al. 2000 \\
\hline Betula alleghaniensis & pot & sym & size-uptake relationship & Berntson and Wayne 2000 \\
\hline $\begin{array}{l}\text { Citrus paradise } \\
\text { Malus domestica }\end{array}$ & in situ & asym & $\begin{array}{l}\text { influence of root age on } \\
\text { uptake kinetics }\end{array}$ & Bouma et al. 2001 \\
\hline $\begin{array}{l}\text { Acer rubrum } \\
\text { Prunus serotina } \\
\text { Quercus rubra }\end{array}$ & pot & asym & $\begin{array}{l}\text { nutrient net gain not } \\
\text { related to root surface } \\
\text { area }\end{array}$ & Kelly et al. 2001 \\
\hline $\begin{array}{l}\text { Fagus sylvatica } \\
\text { Quercus petraea }\end{array}$ & in situ & asym & growth rate, biomass & Leuschner et al. 2001 \\
\hline $\begin{array}{l}\text { Pinus taeda } \\
\text { Liquidambar styraciflua }\end{array}$ & pot & asym & $\begin{array}{l}\text { foraging scale, precision } \\
\text { and rate in heterogene- } \\
\text { ous environments }\end{array}$ & Bliss et al. 2002 \\
\hline $\begin{array}{l}\text { Fagus sylvatica } \\
\text { Picea abies }\end{array}$ & pot & asym & $\begin{array}{l}\text { species-specific uptake } \\
\text { kinetics }\end{array}$ & Gessler et al. 2002 \\
\hline $\begin{array}{l}\text { Fagus sylvatica } \\
\text { Picea abies } \\
\text { Quercus petraea }\end{array}$ & in situ & asym & $\begin{array}{l}\text { species-specific water } \\
\text { uptake kinetics }\end{array}$ & Coners and Leuschner 2005 \\
\hline $\begin{array}{l}\text { Vitis rupestris } x \text { Vitis ri- } \\
\text { paria } \mathrm{cv} .3309 \mathrm{C}\end{array}$ & pot & asym & $\begin{array}{l}\text { declining nitrate uptake } \\
\text { with root age }\end{array}$ & Volder et al. 2005 \\
\hline $\begin{array}{l}\text { Fagus sylvatica } \\
\text { Picea abies }\end{array}$ & in situ & sym & biomass & Bolte 2006 \\
\hline $\begin{array}{l}\text { Carya illnoensis } \\
\text { Gossypium hirsutum }\end{array}$ & in situ & asym & morphological plasticity & Zamora et al. 2007 \\
\hline $\begin{array}{l}\text { Fagus sylvatica } \\
\text { Quercus petraea }\end{array}$ & in situ & asym & $\begin{array}{l}\text { relative growth rate; } \\
\text { foraging scale, morpho- } \\
\text { logical plasticity }\end{array}$ & $\begin{array}{l}\text { This study (Table 4.6, } \\
\text { Fig. 5.1) }\end{array}$ \\
\hline
\end{tabular}


Table A 5 Reviews and models suggesting either symmetric or asymmetric competition belowground.

\begin{tabular}{|c|c|c|c|c|}
\hline Species & $\begin{array}{l}\text { Type } \\
\text { of study }\end{array}$ & $\begin{array}{l}\text { Main } \\
\text { evidence }^{\dagger}\end{array}$ & Rational & Reference \\
\hline & review & sym & $\begin{array}{l}\text { unchanged or lower size } \\
\text { inequality at higher } \\
\text { densities }\end{array}$ & Weiner and Thomas 1986 \\
\hline & review & asym & $\begin{array}{l}\text { superior competitive } \\
\text { ability varies according } \\
\text { to ecological circum- } \\
\text { stances }\end{array}$ & Tilman 1988 \\
\hline & review & sym & patchy resources & Weiner 1990 \\
\hline & review & asym & $\begin{array}{l}\text { nitrogen capture was not } \\
\text { related to root system } \\
\text { size }\end{array}$ & Grime et al. 1991 \\
\hline \multirow[t]{4}{*}{ Larrea tridentate } & $\begin{array}{l}\text { in situ / } \\
\text { model }\end{array}$ & asym & heterogeneous resources & Brisson and Reynolds 1994 \\
\hline & review & asym & $\begin{array}{l}\text { non-biomass-depended, } \\
\text { species-specific response } \\
\text { to nutrient patches }\end{array}$ & Robinson 1994 \\
\hline & model & asym & uptake kinetics & Jackson and Caldwell 1996 \\
\hline & review & sym & $\begin{array}{l}\text { resource uptake, growth, } \\
\text { fecundity }\end{array}$ & Casper and Jackson 1997 \\
\hline \multirow[t]{3}{*}{ Div. } & $\begin{array}{l}\text { model / } \\
\text { review }\end{array}$ & asym & $\begin{array}{l}\text { plasticity in root demog- } \\
\text { raphy }\end{array}$ & Eissenstat and Yanai 1997 \\
\hline & review & $\begin{array}{l}\text { sym / } \\
\text { asym }\end{array}$ & $\begin{array}{l}\text { density, resource uptake, } \\
\text { biomass increment }\end{array}$ & $\begin{array}{l}\text { Schwinning and Weiner } \\
1998\end{array}$ \\
\hline & review & sym & $\begin{array}{l}\text { no effects of soil hetero- } \\
\text { geneity; root biomass }\end{array}$ & Casper et al. 2000 \\
\hline Glycine max & model & asym & foraging, uptake kinetics & Gersani et al. 2001 \\
\hline $\begin{array}{l}\text { Fagus sylvatica } \\
\text { Picea abies }\end{array}$ & review & asym & $\begin{array}{l}\text { space sequestration, } \\
\text { uptake kinetics }\end{array}$ & Grams et al. 2002 \\
\hline \multirow[t]{7}{*}{ Abutilon theophrasti } & model & sym & $\begin{array}{l}\text { advances of nutrient rich } \\
\text { patches are counter- } \\
\text { balanced by a higher root } \\
\text { production }\end{array}$ & Casper et al. 2003 \\
\hline & review & sym & resource availability & de Kroon et al. 2003 \\
\hline & review & asym & $\begin{array}{l}\text { foraging in heterogene- } \\
\text { ous soils }\end{array}$ & Hutchings et al. 2003 \\
\hline & model & asym & $\begin{array}{l}\text { plants outcompete other } \\
\text { plants by pre-empting } \\
\text { nutrient supply }\end{array}$ & Craine et al. 2005 \\
\hline & review & sym & $\begin{array}{l}\text { no benefits of foraging } \\
\text { precision; foraging scale } \\
\text { (biomass) matters }\end{array}$ & Kembel and Cahill 2005 \\
\hline & model & $\begin{array}{l}\text { sym / } \\
\text { asym }\end{array}$ & $\begin{array}{l}\text { space occupation, uptake } \\
\text { rates }\end{array}$ & $\begin{array}{l}\text { Raynaud and Leadley 2004, } \\
2005\end{array}$ \\
\hline & model & sym & $\begin{array}{l}\text { maximizing root length } \\
\text { in the presence of com- } \\
\text { petitor }\end{array}$ & Craine 2006 \\
\hline \multirow[t]{2}{*}{ Fagus sylvatica } & model & asym & Richard equation & Nord-Larsen et al. 2006 \\
\hline & review & asym & patchy resources & Schenk 2006 \\
\hline \multirow[t]{2}{*}{ Div. } & review & asym & $\begin{array}{l}\text { species specific nutrient } \\
\text { uptake rates }\end{array}$ & Lucash et al. 2007 \\
\hline & model & asym & $\begin{array}{l}\text { distance costs, resource } \\
\text { heterogeneity }\end{array}$ & O'Brien et al. 2007 \\
\hline
\end{tabular}

asym (asymmetric competition), sym (symmetric competition). 
Table A 6 Short- and long-term influence of drought or salt stress on axial conductivity and sap flow in conifers.

\begin{tabular}{|c|c|c|c|c|c|c|}
\hline $\begin{array}{l}\text { Gymnosperm tree } \\
\text { species }\end{array}$ & $\begin{array}{l}\text { Type } \\
\text { of } \\
\text { study* }\end{array}$ & $\begin{array}{l}\text { Dura- } \\
\text { tion / } \\
\text { type }\end{array}$ & $\begin{array}{l}\text { Or- } \\
\text { gan }\end{array}$ & Cause & $\begin{array}{l}\text { Effect on } \\
\text { conduc- } \\
\text { tivity }^{\dagger}\end{array}$ & Reference \\
\hline Pinus ponderosa & $\mathrm{M}, \mathrm{F}, \mathrm{d}$ & gradient & $\mathrm{S}$ & $\begin{array}{l}\text { lower } \\
\text { leaf:sapwood } \\
\text { area ratio }\end{array}$ & $+(\mathrm{LSC})$ & Callaway et al. 1994 \\
\hline $\begin{array}{l}\text { Abies lasiocarpa } \\
\text { Larix laricina } \\
\text { Picea glauca }\end{array}$ & $\mathrm{M}, \mathrm{F}, \mathrm{d}$ & $\begin{array}{l}2 \text { sum- } \\
\text { mers }\end{array}$ & $\mathrm{B}$ & embolism & $-\left(\mathrm{k}_{\mathrm{h}}\right)$ & Sperry et al. 1994 \\
\hline Tsuga heterophylla & $\mathrm{S}, \mathrm{F}, \mathrm{d}$ & $10-w k$ & S & embolism & -- (LSC) & $\begin{array}{l}\text { Kavanagh and Zaerr } \\
1997\end{array}$ \\
\hline $\begin{array}{l}\text { Abies concolor } \\
\text { Pseudotsuga menziesii }\end{array}$ & $\begin{array}{l}\mathrm{M}, \mathrm{F} \\
\mathrm{lab}\end{array}$ & & $\begin{array}{l}\mathrm{B}, \mathrm{FR}, \\
\mathrm{CR}\end{array}$ & embolism & $--\left(\mathrm{k}_{\mathrm{h}}\right)$ & Sperry and Ikeda 1997 \\
\hline $\begin{array}{l}\text { Pinus halepensis, } \\
\text { mesic ecotype }\end{array}$ & $\mathrm{S}, \mathrm{P}, \mathrm{d}$ & summer & shoot & embolism & $\begin{array}{l}--(\mathrm{LSC}) \\
--\left(\mathrm{k}_{\mathrm{h}}\right)\end{array}$ & Tognetti et al. 1997 \\
\hline $\begin{array}{l}\text { Pinus halepensis, } \\
\text { xeric ecotype }\end{array}$ & $\mathrm{S}, \mathrm{P}, \mathrm{d}$ & ecotype & shoot & $\begin{array}{l}\text { less embolism, } \\
\text { osmotic ad- } \\
\text { justment }\end{array}$ & $\begin{array}{l}-(\mathrm{LSC}) \\
-\left(\mathrm{k}_{\mathrm{h}}\right)\end{array}$ & Tognetti et al. 1997 \\
\hline Pinus halepensis & $\mathrm{M}, \mathrm{F}, \mathrm{d}$ & 12 -mth & $\mathrm{B}, \mathrm{S}$ & embolism & -- (WP) & Borghetti et al. 1998 \\
\hline Pinus sylvestris & $\mathrm{M}, \mathrm{F}, \mathrm{d}$ & summer & $\mathrm{S}$ & embolism & $\begin{array}{l}-(\mathrm{K}) \\
-(\mathrm{LSC})\end{array}$ & Irvine et al. 1998 \\
\hline $\begin{array}{l}\text { Div. (10 species, semi- } \\
\text { arid } \rightarrow \text { rain forest })\end{array}$ & $\mathrm{S}, \mathrm{L}, \mathrm{d}$ & $\begin{array}{l}\text { gradient, } \\
\text { species }\end{array}$ & shoot & $\begin{array}{l}\Psi_{\text {PLC50 was }} \\
\text { correlated with } \\
\text { habitat mois- } \\
\text { ture }\end{array}$ & - to -- $\left(\mathrm{k}_{\mathrm{h}}\right)$ & Brodribb and Hill 1999 \\
\hline Pinus sylvestris & $\mathrm{M}, \mathrm{F}, \mathrm{s}$ & summer & $\mathrm{R}$ & $\begin{array}{l}\text { shift of water } \\
\text { uptake to } \\
\text { deeper soil } \\
\text { horizons }\end{array}$ & $+(\mathrm{K})$ & Plamboeck et al. 1999 \\
\hline Div. (17 species) & $\begin{array}{l}\text { review, } \\
\text { d }\end{array}$ & $\begin{array}{l}\text { VPD } \\
\text { gradient }\end{array}$ & $\mathrm{S}$ & $\begin{array}{l}\text { lower } \\
\text { leaf:sapwood } \\
\text { area ratio (only } \\
\text { Pinus) }\end{array}$ & $\begin{array}{l}+(\mathrm{LSC}, \\
\text { only } \\
\text { Pinus })\end{array}$ & DeLucia et al. 2000 \\
\hline Pinus taeda & $\mathrm{S}, \mathrm{P}, \mathrm{d}$ & $9-y r$ & $\mathrm{~S}, \mathrm{R}$ & $\begin{array}{l}\text { lower } \\
\text { leaf:sapwood } \\
\text { area ratio, } \\
\text { increased root } \\
\text { biomass }\end{array}$ & $\begin{array}{l}+(\mathrm{LSC}) \\
0(\mathrm{WP}) \\
-\left(\mathrm{k}_{\mathrm{h} \text { root }}\right)\end{array}$ & Ewers et al. 2000 \\
\hline $\begin{array}{l}\text { Pinus ponderosa } \\
\text { (mesic, xeric) }\end{array}$ & $\mathrm{M}, \mathrm{F}, \mathrm{d}$ & ecotype & & $\begin{array}{l}\text { larger tra- } \\
\text { cheids, lower } \\
\text { leaf:sapwood } \\
\text { area ratio }\end{array}$ & $\begin{array}{l}+\left(\mathrm{k}_{\mathrm{s}}\right) \\
+(\mathrm{LSC})\end{array}$ & $\begin{array}{l}\text { Maherali and DeLucia } \\
2000\end{array}$ \\
\hline Pinus sylvestris & $\mathrm{S}, \mathrm{P}, \mathrm{d}$ & 3 -wk & S & & $-\left(\mathrm{k}_{\mathrm{s}}\right)$ & Croise et al. 2001 \\
\hline Pinus sylvestris & $\mathrm{M}, \mathrm{F}, \mathrm{d}$ & gradient & $\mathrm{S}$ & $\begin{array}{l}\text { lower } \\
\text { leaf:sapwood } \\
\text { area ratio }\end{array}$ & $+(\mathrm{LSC})$ & $\begin{array}{l}\text { Mencuccini and } \\
\text { Bonosi } 2001\end{array}$ \\
\hline $\begin{array}{l}\text { Picea abies (dominant, } \\
\text { suppressed trees) }\end{array}$ & $\mathrm{M}, \mathrm{F}, \mathrm{d}$ & summer & $\mathrm{S}$ & embolism & -- $(\mathrm{K})$ & Sellin 2001 \\
\hline
\end{tabular}

*Mature trees (M) or seedlings/saplings (S), in the field (F), pot (P), laboratory (L), or in aeroponics (A), drought stress (d) or salt stress (s). ${ }^{8}$ Manual induction of embolism in the laboratory (air injection/dehydration), diurnal rhythm (diurnal), comparison of ecotypes in contrasting environments (ecotype), comparison of a species along a moisture gradient (gradient), comparison of species in contrasting environments (species), summer drought (summer). ${ }^{*}$ Branch (B), coarse root (CR) fine root (FR), leaf (L), petiole (P), root (R), shoot/stem (S), whole plant (WP). ${ }^{\dagger} 0$ (not influenced), + (marginal increase), ++ (significant increase), - (marginal decrease), -- (significant decrease), Huber value (HV), hydraulic conductivity $\left(\mathrm{k}_{\mathrm{h}}\right)$, specific conductivity $\left(\mathrm{k}_{\mathrm{s}}\right)$, sap flow $(\mathrm{K})$, radial and axial conductivity $\left(\mathrm{L}_{\mathrm{pr}}\right)$, leaf specific conductivity (LSC), and conductivity of the whole plant (WP). 
Table A 6 (continuation) Short- and long-term influence of drought or salt stress on axial conductivity and sap flow in conifers.

\begin{tabular}{|c|c|c|c|c|c|c|}
\hline $\begin{array}{l}\text { Gymnosperm tree } \\
\text { species }\end{array}$ & $\begin{array}{l}\text { Type } \\
\text { of } \\
\text { study* }\end{array}$ & $\begin{array}{l}\text { Dura- } \\
\text { tion / } \\
\text { type }\end{array}$ & $\begin{array}{l}\text { Or- } \\
\text { gan }\end{array}$ & Cause & $\begin{array}{l}\text { Effect on } \\
\text { conduc- } \\
\text { tivity }^{\dagger}\end{array}$ & Reference \\
\hline Pinus laricio & $\mathrm{M}, \mathrm{F}, \mathrm{d}$ & $3-y r$ & $\mathrm{~S}$ & $\begin{array}{l}\text { embolism, } \\
\text { lower } \\
\text { leaf:sapwood } \\
\text { area ratio }\end{array}$ & $\begin{array}{l}--(\mathrm{K}) \\
0\left(\mathrm{k}_{\mathrm{h}}\right) \\
+(\mathrm{LSC})\end{array}$ & Cinnirella et al. 2002 \\
\hline $\begin{array}{l}\text { Pinus ponderosa } \\
\text { (same ecotype from } 7 \\
\text { mesic } \rightarrow \text { xeric habitat) }\end{array}$ & $\begin{array}{l}\mathrm{M} / \mathrm{S} \\
\mathrm{F} / \mathrm{P}, \mathrm{d}\end{array}$ & 9-mth & S & $\begin{array}{l}\text { embolism, } \\
\text { lower } \\
\text { leaf:sapwood } \\
\text { area ratio }\end{array}$ & $\begin{array}{l}--\left(\mathrm{k}_{\mathrm{h}}\right) \\
-\left(\mathrm{k}_{\mathrm{s}}\right) \\
-(\mathrm{LSC})\end{array}$ & Maherali et al. 2002 \\
\hline $\begin{array}{l}\text { Picea banksiana } \\
\text { Pinus mariana }\end{array}$ & $\mathrm{S}, \mathrm{A}, \mathrm{d}$ & $5 \times 3-d$ & $\mathrm{~S}$ & embolism & $\begin{array}{l}--\left(\mathrm{k}_{\mathrm{h}}\right) \\
--\left(\mathrm{k}_{\mathrm{s}}\right) \\
-(\mathrm{LSC})\end{array}$ & Blake and Li 2003 \\
\hline Pinus pinaster & $\mathrm{S}, \mathrm{F}, \mathrm{d}$ & 3-wk & $\mathrm{R}$ & $\begin{array}{l}\text { degradation of } \\
\text { fungal symbi- } \\
\text { ont }\end{array}$ & $-\left(\mathrm{k}_{\mathrm{h}}\right)$ & $\begin{array}{l}\text { Bogeat-Triboult et al. } \\
2004\end{array}$ \\
\hline $\begin{array}{l}\text { Pseudotsuga menziesi } \\
\text { Pinus ponderosa }\end{array}$ & $\mathrm{M}, \mathrm{F}, \mathrm{d}$ & summer & $\mathrm{R}$ & $\begin{array}{l}\text { embolism, } \\
\text { hydraulic } \\
\text { redistribution }\end{array}$ & $\begin{array}{l}--\left(\mathrm{k}_{\mathrm{h}}\right) \\
+(\mathrm{K})\end{array}$ & Domec et al. 2004 \\
\hline Pinus sylvestris & $\mathrm{M}, \mathrm{F}, \mathrm{d}$ & 11-mth & $\mathrm{B}, \mathrm{S}$ & embolism & $-\left(\mathrm{k}_{\mathrm{h}}\right)$ & Perks et al. 2004 \\
\hline Picea abies & $\mathrm{M}, \mathrm{F}, \mathrm{d}$ & 4-mth & $\mathrm{R}$ & & $--(\mathrm{K})$ & Leuschner et al. 2004a \\
\hline $\begin{array}{l}\text { Cedrus atlantica } \\
\text { C. brevifolia } \\
\text { C. libani }\end{array}$ & $\mathrm{S}, \mathrm{F}, \mathrm{d}$ & $\begin{array}{l}2 \times 10- \\
\text { wk }\end{array}$ & $\mathrm{B}, \mathrm{L}, \mathrm{S}$ & $\begin{array}{l}\text { embolism, } \\
\text { decreased } \\
\text { tracheid size, } \\
\text { lower } \Psi_{\text {PLC50 }}\end{array}$ & $\begin{array}{l}--\left(\mathrm{k}_{\mathrm{s}}\right) \\
0 /+(\mathrm{LSC}) \\
++(\mathrm{HV})\end{array}$ & Ladjal et al. 2005 \\
\hline $\begin{array}{l}\text { Pinus echinata } \\
P . \text { palustris } \\
P . \text { taeda }\end{array}$ & $\mathrm{S}, \mathrm{P}, \mathrm{d}$ & $28-d$ & $\mathrm{R}$ & $\begin{array}{l}\text { decreased re- } \\
\text { growth of } \\
\text { roots }\end{array}$ & $--\left(\mathrm{L}_{\mathrm{pr}}\right)$ & $\begin{array}{l}\text { Sword Sayer et al. } \\
2005\end{array}$ \\
\hline $\begin{array}{l}\text { Pinus palustris (mesic, } \\
\text { xeric habitat) }\end{array}$ & $\mathrm{M}, \mathrm{P}, \mathrm{d}$ & gradient & $\mathrm{L}, \mathrm{R}$ & $\begin{array}{l}\text { higher } \\
\text { leaf:sapwood } \\
\text { area ratio, } \\
\text { higher } \\
\text { root:leaf area } \\
\text { ratio }\end{array}$ & $\begin{array}{l}0(\mathrm{LSC}) \\
0\left(\mathrm{k}_{\text {s root }}\right) \\
+(\mathrm{K})\end{array}$ & Addington et al. 2006 \\
\hline Pinus sylvestris & $\mathrm{M}, \mathrm{F}, \mathrm{d}$ & $\begin{array}{l}\text { summer, } \\
\text { gradient }\end{array}$ & $\mathrm{R}$ & & -- $(\mathrm{K})$ & Burk 2006 \\
\hline
\end{tabular}

*Mature trees (M) or seedlings/saplings (S), in the field (F), pot (P), laboratory (L), or in aeroponics (A), drought stress (d) or salt stress (s). ${ }^{\S}$ Manual induction of embolism in the laboratory (air injection/dehydration), diurnal rhythm (diurnal), comparison of ecotypes in contrasting environments (ecotype), comparison of a species along a moisture gradient (gradient), comparison of species in contrasting environments (species), summer drought (summer). ${ }^{*}$ Branch (B), coarse root (CR) fine root (FR), leaf (L), petiole (P), root (R), shoot/stem (S), whole plant (WP). ${ }^{\dagger} 0$ (not influenced), + (marginal increase), ++ (significant increase), - (marginal decrease), -- (significant decrease), Huber value $(\mathrm{HV})$, hydraulic conductivity $\left(\mathrm{k}_{\mathrm{h}}\right)$, specific conductivity $\left(\mathrm{k}_{\mathrm{s}}\right)$, sap flow $(\mathrm{K})$, radial and axial conductivity $\left(\mathrm{L}_{\mathrm{pr}}\right)$, leaf specific conductivity (LSC), and conductivity of the whole plant (WP). 
Table A 7 Short- and long-term influence of drought or salt stress on axial conductivity and sap flow in woody angiosperms.

\begin{tabular}{|c|c|c|c|c|c|c|}
\hline $\begin{array}{l}\text { Angiosperm tree } \\
\text { species }\end{array}$ & $\begin{array}{l}\text { Type } \\
\text { of } \\
\text { study* }\end{array}$ & $\begin{array}{l}\text { Dura- } \\
\text { tion / } \\
\text { type }\end{array}$ & $\begin{array}{l}\text { Or- } \\
\text { gan }\end{array}$ & Cause & $\begin{array}{l}\text { Effect on } \\
\text { conductiv- } \\
\text { ity }\end{array}$ & Reference \\
\hline Citrus jambhiri & $\mathrm{S}, \mathrm{P}, \mathrm{d}$ & $18-d$ & $\mathrm{R}$ & $\begin{array}{l}\text { permeability } \\
\text { of the root cell } \\
\text { membrane }\end{array}$ & $--\left(\mathrm{L}_{\mathrm{pr}}\right)$ & $\begin{array}{l}\text { Ramos and Kauf- } \\
\text { mann } 1979\end{array}$ \\
\hline Citrus spp. (7 species) & $\begin{array}{l}\mathrm{S}, \mathrm{P}, \mathrm{d} / \\
\mathrm{S}\end{array}$ & 5 -mth & $\mathrm{R}$ & & $-\left(\mathrm{L}_{\mathrm{pr}}\right)$ & $\begin{array}{l}\text { Zekri and Parsons } \\
1989\end{array}$ \\
\hline $\begin{array}{l}\text { Quercus alba } \\
\text { Quercus rubra }\end{array}$ & $\mathrm{M}, \mathrm{F}, \mathrm{d}$ & summer & B & embolism & $--\left(k_{h}\right)$ & Cochard 1990 \\
\hline Ceratonia siliqua & $\mathrm{S}, \mathrm{P}, \mathrm{d}$ & 3-wk & $\mathrm{S}$ & embolism & $--\left(k_{h}\right)$ & $\begin{array}{l}\text { Lo Gullo and Salleo } \\
1991\end{array}$ \\
\hline $\begin{array}{l}\text { Fraxinus pennsyl- } \\
\text { vanica }\end{array}$ & $\mathrm{S}, \mathrm{P}, \mathrm{d}$ & summer & $\mathrm{S}$ & $\begin{array}{l}\text { decreased leaf } \\
\text { area }\end{array}$ & $\begin{array}{l}0\left(\mathrm{k}_{\mathrm{s}}\right) \\
+(\mathrm{LSC})\end{array}$ & Shumway et al. 1991 \\
\hline $\begin{array}{l}\text { Quercus petraea } \\
\text { Q. pubescens } \\
\text { Q. robur }\end{array}$ & $\mathrm{M}, \mathrm{F}, \mathrm{d}$ & summer & $\mathrm{B}, \mathrm{P}$ & embolism & -- (LSC) & Cochard et al. $1992 \mathrm{~b}$ \\
\hline Populus deltoides & $\mathrm{S}, \mathrm{L}, \mathrm{d}$ & & B & embolism & $--\left(k_{h}\right)$ & $\begin{array}{l}\text { Lo Gullo and Salleo } \\
1992\end{array}$ \\
\hline $\begin{array}{l}\text { Quercus rubra } \\
\text { Populus deltoides }\end{array}$ & $\begin{array}{l}\mathrm{S}, \mathrm{P} / \mathrm{L}, \\
\mathrm{d}\end{array}$ & & B & embolism & $--\left(\mathrm{k}_{\mathrm{h}}\right)$ & Tyree et al. 1992c \\
\hline $\begin{array}{l}\text { Quercus rubra } \\
\text { Liriodendron tulipif- } \\
\text { era }\end{array}$ & $\mathrm{S}, \mathrm{P}, \mathrm{d}$ & $\begin{array}{l}2 \text { sum- } \\
\text { mers }\end{array}$ & $\mathrm{S}$ & $\begin{array}{l}\text { decreased } \\
\text { leaf:sapwood } \\
\text { area ratio \& } \\
\text { xylem area, } \\
\text { embolism }\end{array}$ & $\begin{array}{l}--(\mathrm{K}) \\
-(\mathrm{LSC})\end{array}$ & Shumway et al. 1993 \\
\hline Betula occidentalis & $\mathrm{S}, \mathrm{P}$ & $\begin{array}{l}\text { air injec- } \\
\text { tion }\end{array}$ & B & embolism & $\begin{array}{l}--\left(k_{h}\right) \\
-(L S C)\end{array}$ & $\begin{array}{l}\text { Sperry and Pockman } \\
1993\end{array}$ \\
\hline Juglans regia & $\mathrm{M}, \mathrm{F}, \mathrm{d}$ & summer & $\mathrm{P}, \mathrm{S}$ & embolism & $\begin{array}{l}--\left(\mathrm{k}_{\mathrm{h} \text { petiole }}\right) \\
-\left(\mathrm{k}_{\mathrm{h} \mathrm{stem}}\right)\end{array}$ & Tyree et al. 1993 \\
\hline Div. (7 species) & $\mathrm{M}, \mathrm{F}, \mathrm{d}$ & summer & $\mathrm{B}$ & embolism & $--\left(k_{h}\right)$ & Sperry et al. 1994 \\
\hline Salvia mellifera & $\begin{array}{l}\text { M, } \\
\text { F/L, d }\end{array}$ & summer & B & embolism & $--\left(\mathrm{k}_{\mathrm{h}}\right)$ & Hargrave et al. 1994 \\
\hline $\begin{array}{l}\text { Salvia mellifera } \\
\text { Ceanothus megacar- } \\
\text { pus }\end{array}$ & $\begin{array}{l}\mathrm{M}, \\
\mathrm{F} / \mathrm{L}, \mathrm{d}\end{array}$ & $\begin{array}{l}\text { summer, } \\
\text { air injec- } \\
\text { tion }\end{array}$ & $\mathrm{S}$ & $\begin{array}{l}\text { embolism, } \\
\text { reduced leaf } \\
\text { area }\end{array}$ & $\begin{array}{l}-/--\left(\mathrm{K}_{\mathrm{h}}\right) \\
+(\mathrm{LSC})\end{array}$ & Kolb and Davis 1994 \\
\hline $\begin{array}{l}\text { Pseudobombax septe- } \\
\text { natum } \\
\text { Ochroma pyramidale }\end{array}$ & $\mathrm{M}, \mathrm{F}, \mathrm{d}$ & summer & $\mathrm{P}, \mathrm{R}, \mathrm{S}$ & embolism & $--(\mathrm{K})$ & $\begin{array}{l}\text { Machado and Tyree } \\
1994\end{array}$ \\
\hline Quercus robur & $\mathrm{S}, \mathrm{P}, \mathrm{d}$ & summer & $\mathrm{B}, \mathrm{P}$ & embolism & $--\left(\mathrm{k}_{\mathrm{h}}\right)$ & Simonin et al. 1994 \\
\hline Betula occidentalis & $\begin{array}{l}\mathrm{M} / \mathrm{S} \\
\mathrm{F} / \mathrm{L}, \mathrm{d}\end{array}$ & $\begin{array}{l}\text { summer, } \\
\text { air injec- } \\
\text { tion }\end{array}$ & $\mathrm{B}, \mathrm{S}$ & embolism & $--\left(\mathrm{k}_{\mathrm{h}}\right)$ & $\begin{array}{l}\text { Sperry and Saliendra } \\
1994\end{array}$ \\
\hline $\begin{array}{l}\text { Populus deltoides } \\
\text { P. balsamifera } \\
\text { P. angustifolia }\end{array}$ & $\mathrm{S}, \mathrm{P}, \mathrm{d}$ & summer & $\mathrm{S}$ & embolism & $--\left(\mathrm{k}_{\mathrm{h}}\right)$ & Tyree et al. 1994 \\
\hline $\begin{array}{l}\text { Malosma laurina } \\
\text { Heteromeles arbutifo- } \\
\text { lia }\end{array}$ & $\begin{array}{l}\text { M, } \\
\text { F/L, d }\end{array}$ & $\begin{array}{l}\text { air injec- } \\
\text { tion }\end{array}$ & B & embolism & $--\left(k_{h}\right)$ & Jarbeau et al. 1995 \\
\hline
\end{tabular}

\footnotetext{
*Mature trees (M) or seedlings/saplings (S), in the field (F), pot (P), laboratory (L), or in aeroponics (A), drought stress (d) or salt stress (s). ${ }^{\$}$ Manual induction of embolism in the laboratory (air injection/dehydration), diurnal rhythm (diurnal), comparison of ecotypes in contrasting environments (ecotype), comparison of a species along a moisture gradient (gradient), comparison of species in contrasting environments (species), summer drought (summer); ${ }^{*}$ Branch (B), coarse root (CR) fine root (FR), leaf (L), petiole (P), root (R), shoot/stem (S), whole plant (WP). ${ }^{\dagger} 0$ (not influenced), + (marginal increase), ++ (significant increase), - (marginal decrease), -- (significant decrease), Huber value $(\mathrm{HV})$, hydraulic conductivity $\left(\mathrm{k}_{\mathrm{h}}\right)$, specific conductivity $\left(\mathrm{k}_{\mathrm{s}}\right)$, sap flow $(\mathrm{K})$, radial and axial conductivity $\left(\mathrm{L}_{\mathrm{pr}}\right)$, leaf specific conductivity (LSC), and conductivity of the whole plant (WP).
} 
Table A 7 (continuation) Short- and long-term influence of drought or salt stress on axial conductivity and sap flow in woody angiosperms.

\begin{tabular}{|c|c|c|c|c|c|c|}
\hline $\begin{array}{l}\text { Angiosperm tree } \\
\text { species }\end{array}$ & $\begin{array}{l}\text { Type } \\
\text { of } \\
\text { study* }\end{array}$ & $\begin{array}{l}\text { Dura- } \\
\text { tion / } \\
\text { type }\end{array}$ & $\begin{array}{l}\text { Or- } \\
\text { gan }\end{array}$ & Cause & $\begin{array}{l}\text { Effect on } \\
\text { conductiv- } \\
\text { ity }\end{array}$ & Reference \\
\hline Hevea brasiliensis & $\begin{array}{l}\mathrm{S}, \mathrm{P} / \mathrm{L}, \\
\mathrm{d}\end{array}$ & $\begin{array}{l}\text { air injec- } \\
\text { tion }\end{array}$ & $\mathrm{P}, \mathrm{S}$ & embolism & $--\left(\mathrm{k}_{\mathrm{h}}\right)$ & $\begin{array}{l}\text { Ranasinghe and } \\
\text { Milburn } 1995\end{array}$ \\
\hline $\begin{array}{l}\text { Olea europaea } \\
\text { Prunus persica } \\
\text { Poncirus trifoliata } \times \\
\text { Citrus paradisi } \\
\text { Pistachia integerrima }\end{array}$ & $\mathrm{S}, \mathrm{P}, \mathrm{d}$ & $25-45-d$ & $\mathrm{R}$ & & $--\left(\mathrm{L}_{\mathrm{pr}}\right)$ & Rieger 1995 \\
\hline $\begin{array}{l}\text { Fagus sylvatica } \\
\text { (mesic, xeric eco- } \\
\text { types) }\end{array}$ & $\mathrm{S}, \mathrm{P}, \mathrm{d}$ & $8 / 10-d$ & $\mathrm{~S}$ & embolism & $\begin{array}{l}--\left(\mathrm{k}_{\mathrm{h}}\right) \\
--(\mathrm{LSC})\end{array}$ & Tognetti et al. 1995 \\
\hline Acer grandidentatum & $\mathrm{M}, \mathrm{F}, \mathrm{d}$ & gradient & S & embolism & $--\left(\mathrm{k}_{\mathrm{h}}\right)$ & Alder et al. 1996 \\
\hline $\begin{array}{l}\text { Populus (mesic, xeric } \\
\text { ecotypes) }\end{array}$ & $\mathrm{M}, \mathrm{F}, \mathrm{d}$ & gradient & $\mathrm{S}$ & $\begin{array}{l}\text { larger } \Psi_{\text {PLC50 }} \\
\& \text { vessels in } \\
\text { xeric ecotypes }\end{array}$ & $+\left(\mathrm{k}_{\mathrm{h}}\right)$ & Blake et al. 1996 \\
\hline $\begin{array}{l}\text { Populus trichocarpa } \\
\text { P. deltoides (drought- } \\
\text { sensitive and - } \\
\text { resistant clones) }\end{array}$ & $\mathrm{S}, \mathrm{P}, \mathrm{d}$ & species & $\mathrm{S}$ & $\begin{array}{l}\text { larger vessels } \\
\text { in drought- } \\
\text { resistant clone, } \\
\text { embolism }\end{array}$ & $\begin{array}{l}+\left(\mathrm{k}_{\mathrm{s} \text { theo }}\right) \\
--\left(\mathrm{k}_{\mathrm{h}}\right)\end{array}$ & $\begin{array}{l}\text { Harvey and van der } \\
\text { Driessche } 1997\end{array}$ \\
\hline $\begin{array}{l}\text { Rhus laurina } \\
\text { Ceanothus megacar- } \\
\text { pus }\end{array}$ & $\mathrm{M}, \mathrm{F}, \mathrm{d}$ & summer & S & embolism & $--\left(\mathrm{k}_{\mathrm{h}}\right)$ & Langan et al. 1997 \\
\hline Olea oleaster & $\mathrm{S}, \mathrm{P}, \mathrm{d}$ & 6-mth & $\mathrm{R}$ & suberization & $--\left(\mathrm{L}_{\mathrm{pr}}\right)$ & Lo Gullo et al. 1998 \\
\hline Vitis vinifera & $\mathrm{M}, \mathrm{P}, \mathrm{d}$ & $40-\mathrm{d}$ & S & $\begin{array}{l}\text { decreased leaf } \\
\text { area, rel. } \\
\text { higher xylem } \\
\text { area }\end{array}$ & $\begin{array}{l}0 /-(\mathrm{LSC}) \\
0 /-\left(\mathrm{k}_{\mathrm{s}}\right) \\
-\left(\mathrm{k}_{\mathrm{h}}\right)\end{array}$ & $\begin{array}{l}\text { Lovisolo and Schu- } \\
\text { bert } 1998\end{array}$ \\
\hline $\begin{array}{l}\text { Quercus pubescens } \\
\text { Q. ilex }\end{array}$ & $\mathrm{M}, \mathrm{F}, \mathrm{d}$ & summer & $\mathrm{B}$ & embolism & $\begin{array}{l}--\left(k_{h}\right) \\
-(K)\end{array}$ & Tognetti et al. 1998 \\
\hline $\begin{array}{l}\text { Ceanothus spp ( } 3 \\
\text { species, mesic } \rightarrow \\
\text { xeric habitats) }\end{array}$ & $\mathrm{M}, \mathrm{F}, \mathrm{d}$ & gradient & S & embolism & $--\left(\mathrm{k}_{\mathrm{h}}\right)$ & Davis et al. 1999 \\
\hline Quercus pubescens & $\begin{array}{l}\mathrm{S}, \mathrm{F} / \mathrm{P} \\
\mathrm{d}\end{array}$ & summer & $\mathrm{R}, \mathrm{S}$ & embolism & $\begin{array}{l}0\left(\mathrm{k}_{\mathrm{h} \mathrm{root}}\right) \\
--\left(\mathrm{k}_{\mathrm{h} \text { shoot }}\right)\end{array}$ & Nardini and Pitt 1999 \\
\hline $\begin{array}{l}\text { Populus trichocarpa } \\
\text { ( } 4 \text { mesic } \rightarrow \text { xeric } \\
\text { habitats) }\end{array}$ & $\begin{array}{l}\text { M, } \\
\mathrm{P} / \mathrm{L}, \mathrm{d}\end{array}$ & $\begin{array}{l}\text { gradient, } \\
\text { air injec- } \\
\text { tion }\end{array}$ & $\mathrm{S}$ & $\begin{array}{l}\text { lower } \Psi_{\text {PLC50 }} \\
\& \mathrm{k}_{\mathrm{s}} \text { in xeric } \\
\text { ecotypes }\end{array}$ & $0\left(\mathrm{k}_{\mathrm{h}}\right)$ & $\begin{array}{l}\text { Sparks and Black } \\
1999\end{array}$ \\
\hline $\begin{array}{l}\text { Acer rubrum } \\
\text { Liriodendron tulipif- } \\
\text { era } \\
\text { Vitis labrusca }\end{array}$ & $\mathrm{M}, \mathrm{F}, \mathrm{d}$ & diurnal & $\mathrm{P}$ & embolism & $-/--\left(\mathrm{k}_{\mathrm{h}}\right)$ & $\begin{array}{l}\text { Zwieniecki et al. } \\
2000\end{array}$ \\
\hline Avicennia germinans & $\mathrm{M}, \mathrm{F}, \mathrm{s}$ & 6-mth & $\mathrm{S}$ & embolism & $\begin{array}{l}--(\mathrm{LSC}) \\
--\left(\mathrm{k}_{\mathrm{s}}\right)\end{array}$ & Sobrado 2001 \\
\hline $\begin{array}{l}\text { Quercus robur } \\
\text { Quercus petraea }\end{array}$ & $\mathrm{S}, \mathrm{P}, \mathrm{d}$ & 8-wk & $\mathrm{B}$ & $\begin{array}{l}\text { decreased } \\
\text { sapwood, } \\
\text { embolism }\end{array}$ & $\begin{array}{l}0 /--\left(\mathrm{k}_{\mathrm{h}}\right) \\
--\left(\mathrm{k}_{\mathrm{s}}\right)\end{array}$ & $\begin{array}{l}\text { Gieger 2002, Gieger } \\
\text { and Thomas } 2002\end{array}$ \\
\hline
\end{tabular}

*Mature trees (M) or seedlings/saplings (S), in the field (F), pot (P), laboratory (L), or in aeroponics (A), drought stress (d) or salt stress (s). ${ }^{8}$ Manual induction of embolism in the laboratory (air injection/dehydration), diurnal rhythm (diurnal), comparison of ecotypes in contrasting environments (ecotype), comparison of a species along a moisture gradient (gradient), comparison of species in contrasting environments (species), summer drought (summer). ${ }^{*}$ Branch (B), coarse root (CR) fine root (FR), leaf (L), petiole (P), root (R), shoot/stem (S), whole plant (WP). ${ }^{\dagger} 0$ (not influenced), + (marginal increase), ++ (significant increase), - (marginal decrease), -- (significant decrease), Huber value $(\mathrm{HV})$, hydraulic conductivity $\left(\mathrm{k}_{\mathrm{h}}\right)$, specific conductivity $\left(\mathrm{k}_{\mathrm{s}}\right)$, sap flow $(\mathrm{K})$, radial and axial conductivity $\left(\mathrm{L}_{\mathrm{pr}}\right)$, leaf specific conductivity (LSC), and conductivity of the whole plant (WP). 
Table A 7 (continuation) Short- and long-term influence of drought or salt stress on axial conductivity and sap flow in woody angiosperms.

\begin{tabular}{|c|c|c|c|c|c|c|}
\hline $\begin{array}{l}\text { Angiosperm tree } \\
\text { species }\end{array}$ & $\begin{array}{l}\text { Type } \\
\text { of } \\
\text { study* }\end{array}$ & $\begin{array}{l}\text { Dura- } \\
\text { tion / } \\
\text { type }\end{array}$ & $\begin{array}{l}\text { Or- } \\
\text { gan }\end{array}$ & Cause & $\begin{array}{l}\text { Effect on } \\
\text { conductiv- } \\
\text { ity }^{\dagger}\end{array}$ & Reference \\
\hline Populus tremuloides & $\mathrm{S}, \mathrm{P}, \mathrm{d}$ & $16-d$ & $\mathrm{R}$ & $\begin{array}{l}\text { embolism, } \\
\text { aquaporin } \\
\text { expression }\end{array}$ & $--\left(\mathrm{L}_{\mathrm{pr}}\right)$ & $\begin{array}{l}\text { Siemens and Zwi- } \\
\text { azek } 2003\end{array}$ \\
\hline $\begin{array}{l}\text { Pistacia lentiscus } \\
\text { Quercus coccifera }\end{array}$ & $\begin{array}{l}\mathrm{S}, \mathrm{P} / \mathrm{L}, \\
\mathrm{d}\end{array}$ & $\begin{array}{l}\text { summer, } \\
\text { dehydra- } \\
\text { tion }\end{array}$ & B & embolism & $\begin{array}{l}--(\mathrm{LSC}) \\
--\left(\mathrm{k}_{\mathrm{h}}\right)\end{array}$ & Vilagrosa et al. 2003 \\
\hline $\begin{array}{l}\text { Fagus sylvatica } \\
\text { Quercus petraea }\end{array}$ & $\mathrm{M}, \mathrm{F}, \mathrm{d}$ & summer & $\mathrm{R}$ & & $--(\mathrm{K})$ & $\begin{array}{l}\text { Leuschner et al. } \\
2004 \mathrm{a}\end{array}$ \\
\hline $\begin{array}{l}\text { Eucalyptus crebra } \\
\text { E. xanthoclada }\end{array}$ & $\begin{array}{l}\mathrm{M} / \mathrm{S} \\
\mathrm{F} / \mathrm{L}, \mathrm{d}\end{array}$ & $\begin{array}{l}\text { summer, } \\
\text { air injec- } \\
\text { tion }\end{array}$ & S & embolism & $--\left(k_{h}\right)$ & Rice et al. 2004 \\
\hline $\begin{array}{l}\text { Eucalyptus grandis } \\
\text { E. sideroxylon } \\
\text { E. occidentalis }\end{array}$ & $\mathrm{S}, \mathrm{P}, \mathrm{d}$ & 6-wk & $\mathrm{S}$ & $\begin{array}{l}\text { reduced vessel } \\
\text { size and den- } \\
\text { sity }\end{array}$ & $-\left(\mathrm{k}_{\mathrm{s} \text { theo }}\right)$ & Searson et al. 2004 \\
\hline Populus tremuloides & $\mathrm{S}, \mathrm{A}, \mathrm{d}$ & $17-20-\mathrm{h}$ & $\mathrm{R}$ & $\begin{array}{l}\text { aquaporin } \\
\text { expression }\end{array}$ & $+/-\left(\mathrm{L}_{\mathrm{pr}}\right)$ & $\begin{array}{l}\text { Siemens and Zwi- } \\
\text { azek } 2004\end{array}$ \\
\hline $\begin{array}{l}\text { Fagus sylvatica } \\
\text { Betula pendula }\end{array}$ & $\mathrm{M}, \mathrm{F}, \mathrm{d}$ & summer & $\mathrm{R}$ & & -- (K) & Burk 2006 \\
\hline $\begin{array}{l}\text { Populus euphratica } \\
\text { P. } \times \text { canescens }\end{array}$ & $\mathrm{M}, \mathrm{F}, \mathrm{s}$ & 6-wk & $\mathrm{S}$ & $\begin{array}{l}\text { reduced vessel } \\
\text { size }\end{array}$ & $0 /-\left(\mathrm{k}_{\mathrm{h} \text { theo }}\right)$ & Junghans et al. 2006 \\
\hline $\begin{array}{l}\text { Rhizophora mucro- } \\
\text { nata }\end{array}$ & $\mathrm{M}, \mathrm{F}, \mathrm{s}$ & gradient & $\mathrm{S}$ & $\begin{array}{l}\text { increased } \\
\text { vessel density, } \\
\text { decreased } \\
\text { vessel size }\end{array}$ & - $\left(\mathrm{k}_{\mathrm{s} \text { theo }}\right)$ & Schmitz et al. 2006 \\
\hline $\begin{array}{l}\text { Olea europaea ( } 3 \\
\text { varieties) }\end{array}$ & $\mathrm{S}, \mathrm{P}, \mathrm{d}$ & $15-w k$ & $\mathrm{~S}$ & $\begin{array}{l}\text { increased } \\
\text { vessel density, } \\
\text { vessel diame- } \\
\text { ter: inconsis- } \\
\text { tent }\end{array}$ & $0 /+\left(\mathrm{k}_{\mathrm{h} \text { theo }}\right)$ & Bacelar et al. 2007 \\
\hline $\begin{array}{l}\text { Vitis berlandieri } \times \\
\text { rupestris }\end{array}$ & $\mathrm{M}, \mathrm{F}, \mathrm{d}$ & $7-d$ & $\mathrm{~S}$ & $\begin{array}{l}\text { aquaporin } \\
\text { expression }\end{array}$ & $+\left(\mathrm{k}_{\mathrm{h}}\right)$ & Galmes et al. 2007 \\
\hline Arbutus unedo & $\mathrm{S}, \mathrm{P}, \mathrm{s}$ & 16-wk & $\mathrm{R}$ & & $--\left(\mathrm{L}_{\mathrm{pr}}\right)$ & Navarro et al. 2007 \\
\hline Vitis spp. (5 varieties) & $\mathrm{M}, \mathrm{F}, \mathrm{d}$ & summer & S & embolism & $--\left(k_{h}\right)$ & Pire et al. 2007 \\
\hline $\begin{array}{l}\text { Laguncularia ra- } \\
\text { cemosa }\end{array}$ & $\mathrm{S}, \mathrm{P}, \mathrm{s}$ & & S & $\begin{array}{l}\text { increased } \\
\text { vessel density, } \\
\text { decreased } \\
\text { vessel size }\end{array}$ & $\begin{array}{l}--\left(\mathrm{k}_{\mathrm{h}}\right) \\
--\left(\mathrm{k}_{\mathrm{s}}\right)\end{array}$ & Sobrado 2007 \\
\hline $\begin{array}{l}\text { Olea europea var. ( } 3 \\
\text { varieties) }\end{array}$ & $\mathrm{M}, \mathrm{F}, \mathrm{s}$ & $7-\mathrm{yr}$ & $\mathrm{R}, \mathrm{S}$ & $\begin{array}{l}\text { increased } \\
\text { vessel density, } \\
\text { high conduc- } \\
\text { tivity roots }\end{array}$ & $\begin{array}{l}++\left(\mathrm{k}_{\mathrm{h} \text { root }}\right) \\
++\left(\mathrm{k}_{\mathrm{s} \text { root }}\right) \\
0\left(\mathrm{k}_{\mathrm{s} \text { shoot }}\right)\end{array}$ & $\begin{array}{l}\text { This study (Ta- } \\
\text { bles } 3.1,3.4 \text { ) }\end{array}$ \\
\hline $\begin{array}{l}\text { Fagus sylvatica } \\
\text { Quercus petraea }\end{array}$ & $\begin{array}{l}\mathrm{M} / \mathrm{S} \\
\mathrm{F} / \mathrm{P}, \mathrm{d}\end{array}$ & $2 / 3-y r$ & $\mathrm{R}, \mathrm{S}$ & $\begin{array}{l}\text { embolism, } \\
\text { xylem anat- } \\
\text { omy }\end{array}$ & $\begin{array}{l}--\left(\mathrm{k}_{\mathrm{s} \text { shoot }}\right) \\
-/++\left(\mathrm{k}_{\mathrm{s} \text { root }}\right)\end{array}$ & $\begin{array}{l}\text { This study (Figs. 2.1, } \\
\text { 2.2, 2.3, Table 2.3) }\end{array}$ \\
\hline
\end{tabular}

*Mature trees (M) or seedlings/saplings (S), in the field (F), pot (P), laboratory (L), or in aeroponics (A), drought stress (d) or salt stress (s). ${ }^{\S}$ Manual induction of embolism in the laboratory (air injection/dehydration), diurnal rhythm (diurnal), comparison of ecotypes in contrasting environments (ecotype), comparison of a species along a moisture gradient (gradient), comparison of species in contrasting environments (species), summer drought (summer). ${ }^{*}$ Branch (B), coarse root (CR) fine root (FR), leaf (L), petiole (P), root (R), shoot/stem (S), whole plant (WP). ${ }^{\dagger} 0$ (not influenced), + (marginal increase), ++ (significant increase), - (marginal decrease), -- (significant decrease), Huber value $(\mathrm{HV})$, hydraulic conductivity $\left(\mathrm{k}_{\mathrm{h}}\right)$, specific conductivity $\left(\mathrm{k}_{\mathrm{s}}\right)$, sap flow $(\mathrm{K})$, radial and axial conductivity $\left(\mathrm{L}_{\mathrm{pr}}\right)$, leaf specific conductivity (LSC), and conductivity of the whole plant (WP). 


\section{REFERENCES}

Addington RN, Donovan LA, Mitchell RJ, Vose JM, Pecot SD, Jack SB, Hacke UG, Sperry JS, Oren R. 2006. Adjustments in hydraulic architecture of Pinus palustris maintain similar stomatal conductance in xeric and mesic habitats. Plant, Cell and Environment 29: 535-545.

Aerts R, Boot RGA, Van der Aart PJM. 1991. The relation between aboveground and belowground biomass allocation patterns and competitive ability. Oecologia 87: 551-559.

Alder NN, Sperry JS, Pockman WT. 1996. Root and stem xylem embolism, stomatal conductance, and leaf turgor in Acer grandidentatum populations along a soil moisture gradient. Oecologia 105: 293-301.

Aspelmeier S, Leuschner C. 2006. Genotypic variation in drought response of Silver birch (Betula pendula Rотн.): leaf and root morphology and carbon partitioning. Trees - Structure and Function 20: $42-52$.

Bacelar EA, Moutinho-Pereira JM, Goncalves BC, Ferreira HF, Correia CM. 2007. Changes in growth, gas exchange, xylem hydraulic properties and water use efficiency of three olive cultivars under contrasting water availability regimes. Environmental and Experimental Botany 60: 183-192.

Berntson GM, Wayne PM. 2000. Characterizing the size dependence of resource acquisition within crowded plant populations. Ecology 81: 1072-1085.

Blair B. 2001. Effect of soil nutrient heterogeneity on the symmetry of belowground competition. Plant Ecology 156: 199-203.

Blake TJ, Sperry JS, Tschaplinski TJ, Wang SS. 1996. Water relations. In: Stettler RF, Bradshaw JH, Heilman PE, Hinckley TM, eds. Biology of Populus and its implications for management and conservation. Ottawa, Canada: NRC Research Press, 401-422.

Blake TJ, Li JY. 2003. Hydraulic adjustment in Jack pine and Black spruce seedlings under controlled cycles of dehydration and rehydration. Physiologia Plantarum 117: 532-539.

Bliss KM, Jones RH, Mitchell RJ, Mou PP. 2002. Are competitive interactions influenced by spatial nutrient heterogeneity and root foraging behavior? New Phytologist 154: 409-417.

Bogeat-Triboulot MB, Bartoli F, Garbaye J, Marmeisse R, Tagu D. 2004. Fungal ectomycorrhizal community and drought affect root hydraulic properties and soil adherence to roots of Pinus pinaster seedlings. Plant and Soil 267: 213-223.

Bolte A, Villanueva I. 2006. Interspecific competition impacts on the morphology and distribution of fine roots in European beech (Fagus sylvatica L.) and Norway spruce (Picea abies (L.) KARST.). European Journal of Forest Research 125: 15-26.

Bongarten BC, Teskey RO. 1987. Dry-weight partitioning and its relationship to productivity in Loblolly pine seedlings from seven sources. Forest Science 33: 255-267.

Borghetti M, Cinnirella S, Magnani F, Saracino A. 1998. Impact of long-term drought on xylem embolism and growth in Pinus halepensis MiLL.. Trees - Structure and Function 12: 187-195.

Bouma TJ, Yanai RD, Elkin AD, Hartmond U, Flores-Alva DE, Eissenstat DM. 2001. Estimating agedependent costs and benefits of roots with contrasting life span: comparing apples and oranges. New Phytologist 150: 685-695.

Bredemeier M, Blanck K, Dohrenbusch A, Lamersdorf N, Meyer AC, Murach D, Parth A, Xu YJ. 1998. The Solling roof project - Site characteristics, experiments and results. Forest Ecology and Management 101: 281-293.

Brisson J, Reynolds JF. 1994. The effect of neighbors on root distribution in a creosotebush (Larrea tridentata) population. Ecology 75: 1693-1702.

Brodribb TJ, Hill RS. 1999. The importance of xylem constraints in the distribution of conifer species. New Phytologist 143: 365-372. 
Burk D. 2006. Physiological, anatomical and chemical aspects of the regulation of water uptake by beech, pine and birch roots in two different water-supplying locations (In German). PhD thesis. University of Göttingen, Germany.

Cahill JF. 1997. Symmetry, intensity, and additivity: belowground interactions in an early successional field. PhD thesis, University of Pennsylvania, USA.

Cahill JF. 1999. Fertilization effects on interactions between above- and belowground competition in an old field. Ecology 80: 466-480.

Cahill JF, Casper BB. 2000. Investigating the relationship between neighbor root biomass and belowground competition: field evidence for symmetric competition belowground. Oikos 90: 311-320.

Cahill JF. 2003. Neighbourhood-scale diversity, composition and root crowding do not alter competition during drought in a native grassland. Ecology Letters 6: 599-603.

Caldwell MM, Eissenstat DM, Richards JH, Allen MF. 1985. Competition for phosphorus - Differential uptake from dual-isotope labelled soil interspaces between shrub and grass. Science 229: 384-386.

Callaway RM, DeLucia EH, Schlesinger WH. 1994. Biomass allocation of montane and desert Ponderosa pine - An analog for response to climate-change. Ecology 75: 1474-1481.

Campbell BD, Grime JP, Mackey JML. 1991a. A trade-off between scale and precision in resource foraging. Oecologia 87: 532-538.

Campbell BD, Grime JP, Mackey JML, Jalili A. 1991b. The quest for a mechanistic understanding of resource competition in plant-communities - the role of experiments. Functional Ecology 5: 241-253.

Casper BB, Jackson RB. 1997. Plant competition underground. Annual Review of Ecology and Systematics 28: 545-570.

Casper BB, Cahill JF, Hyatt LA. 1998. Above-ground competition does not alter biomass allocated to roots in Abutilon theophrasti. New Phytologist 140: 231-238.

Casper BB, Cahill JF, Jackson RB. 2000. Plant competition in spatial heterogeneous environments. In: Hutchings MJ, John EA, Stewart AJA, eds. Ecological consequences of habitat heterogeneity. Oxford, UK: Blackwell, 111-130.

Casper BB, Schenk HJ, Jackson RB. 2003. Defining a plant's belowground zone of influence. Ecology 84: 2313-2321.

Casper BB, Castelli JP. 2007. Evaluating plant-soil feedback together with competition in a serpentine grassland. Ecology Letters 10: 394-400.

Chiatante D, Di Iorio A, Scippa GS. 2005. Root responses of Quercus ilex L. seedlings to drought and fire. Plant Biosystems 139: 198-208.

Chiatante D, Di Iorio A, Sciandra S, Scippa GS, Mazzoleni S. 2006. Effect of drought and fire on root development in Quercus pubescens WILLD. and Fraxinus ornus L. seedlings. Environmental and Experimental Botany 56: 190-197.

Cinnirella S, Magnani F, Saracino A, Borghetti M. 2002. Response of a mature Pinus laricio plantation to a three-year restriction of water supply: structural and functional acclimation to drought. Tree Physiology 22: 21-30.

Climent JM, Aranda I, Alonso J, Pardos JA, Gil L. 2006. Developmental constraints limit the response of Canary Island pine seedlings to combined shade and drought. Forest Ecology and Management 231: 164-168.

Cochard H, Tyree MT. 1990. Xylem dysfunction in Quercus - Vessel sizes, tyloses, cavitation and seasonal-changes in embolism. Tree Physiology 6: 393-407.

Cochard H, Bréda N, Granier A, Aussenac G. 1992. Vulnerability to air-embolism of three European oak species (Quercus petraea (MATT.) LIEBL., Quercus pubescens WiLlD., Quercus robur L.). Annals of Forest Science 49: 225-233.

Comeau PG, Kimmins JP. 1989. Above- and below-ground biomass and production of Lodgepole pine on sites with differing soil moisture regimes. Canadian Journal of Forest Research 19: 447-454.

Coners H, Leuschner C. 2005. In situ measurement of fine root water absorption in three temperate tree species - Temporal variability and control by soil and atmospheric factors. Basic and Applied Ecology 6: 395-405. 
Cortina J, Green JJ, Baddeley JA, Watson CA. 2008. Root morphology and water transport of Pistacia lentiscus seedlings under contrasting water supply: A test of the pipe stem theory. Environmental and Experimental Botany 62: 343-350.

Craine JM, Fargione J, Sugita S. 2005. Supply pre-emption, not concentration reduction, is the mechanism of competition for nutrients. New Phytologist 166: 933-940.

Craine JM. 2006. Competition for nutrients and optimal root allocation. Plant and Soil 285: 171-185.

Crick JC, Grime JP. 1987. Morphological plasticity and mineral nutrient capture in two herbaceous species of contrasted ecology. New Phytologist 107: 403-414.

Croise L, Lieutier F, Cochard H, Dreyer E. 2001. Effects of drought stress and high density stem inoculations with Leptographium wingfieldii on hydraulic properties of young Scots pine trees. Tree Physiology 21: 427-436.

Davidson SR, Ashmore MR, Garretty C. 1992. Effects of ozone and water deficit on the growth and physiology of Fagus sylvatica. Forest Ecology and Management 51: 187-193.

Davis SD, Ewers FW, Wood J, Reeves JJ, Kolb KJ. 1999. Differential susceptibility to xylem cavitation among three pairs of Ceanothus species in the Transverse Mountain Ranges of southern California. Ecoscience 6: 180-186.

Day KJ, John EA, Hutchings MJ. 2003. The effects of spatially heterogeneous nutrient supply on yield, intensity of competition and root placement patterns in Briza media and Festuca ovina. Functional Ecology 17: 454-463.

de Kroon H, Mommer L, Nishiwaki A. 2003. Root competition: Towards a mechanistic understanding. In: de Kroon H, Visser EJW, eds. Root Ecology. Berlin, Germany: Springer, 215-235.

de Visser PHB, Beier C, Rasmussen L, Kreutzer K, Steinberg N, Bredemeier M, Blanck K, Farrell EP, Cummins T. 1994. Biological response of five forest ecosystems in the EXMAN project to input changes of water, nutrients and atmospheric loads. Forest Ecology and Management 68: 15-29.

DeLucia EH, Maherali H, Carey EV. 2000. Climate-driven changes in biomass allocation in pines. Global Change Biology 6: 587-593.

Devakumar AS, Prakash PG, Jacob J. 1999. Drought alters the canopy architecture and micro-climate of Hevea brasiliensis trees. Trees - Structure and Function 13: 161-167.

Dickmann DI, Nguyen PV, Pregitzer KS. 1996. Effects of irrigation and coppicing on above-ground growth, physiology, and fine-root dynamics of two field-grown hybrid poplar clones. Forest Ecology and Management 80: 163-174.

Domec JC, Warren JM, Meinzer FC, Brooks JR, Coulombe R. 2004. Native root xylem embolism and stomatal closure in stands of Douglas fir and Ponderosa pine: Mitigation by hydraulic redistribution. Oecologia 141: 7-16.

Einsmann JC, Jones RH, Pu M, Mitchell RJ. 1999. Nutrient foraging traits in ten co-occurring plant species of contrasting life forms. Journal of Ecology 87: 609-619.

Eissenstat DM, Yanai RD. 1997. The ecology of root lifespan. Advances in Ecological Research 27: 1-60.

Ennik GL, Baan Hofman T. 1983. Variation in the root mass of ryegrass types and its ecological consequences. Netherlands Journal of Agricultural Science 31 / 30: 325.

Ewers BE, Oren R, Sperry JS. 2000. Influence of nutrient versus water supply on hydraulic architecture and water balance in Pinus taeda. Plant, Cell and Environment 23: 1055-1066.

Facelli E, Facelli JM. 2002. Soil phosphorus heterogeneity and mycorrhizal symbiosis regulate plant intra-specific competition and size distribution. Oecologia 133: 54-61.

Farley RA, Fitter AH. 1999. Temporal and spatial variation in soil resources in a deciduous woodland. Journal of Ecology 87: 688-696.

Farley RA, Fitter AH. 1999. The responses of seven co-occurring woodland herbaceous perennials to localized nutrient-rich patches. Journal of Ecology 87: 849-859.

Fort C, Fauveau ML, Muller F, Label P, Granier A, Dreyer E. 1997. Stomatal conductance, growth and root signaling in young oak seedlings subjected to partial soil drying. Tree Physiology 17: 281-289. 
Fort C, Muller F, Label P, Granier A, Dreyer E. 1998. Stomatal conductance, growth and root signaling in Betula pendula seedlings subjected to partial soil drying. Tree Physiology 18: 769-776.

Fotelli MN, Geßler A, Peuke AD, Rennenberg H. 2001. Drought affects the competitive interactions between Fagus sylvatica seedlings and an early successional species, Rubus fruticosus: responses of growth, water status and $\delta^{13} \mathrm{C}$ composition. New Phytologist 151: 427-435.

Fransen B, de Kroon H, Berendse F. 1998. Root morphological plasticity and nutrient acquisition of perennial grass species from habitats of different nutrient availability. Oecologia 115: 351-358.

Fransen B, Blijjenberg J, de Kroon H. 1999. Root morphological and physiological plasticity of perennial grass species and the exploitation of spatial and temporal heterogeneous nutrient patches. Plant and Soil 211: 179-189.

Fransen B, de Kroon H, Berendse F. 2001. Soil nutrient heterogeneity alters competition between two perennial grass species. Ecology 82: 2534-2546.

Fransen B, de Kroon H. 2001. Long-term disadvantages of selective root placement: root proliferation and shoot biomass of two perennial grass species in a 2-year experiment. Journal of Ecology 89: 711-722.

Galmes J, Pou A, Alsina MM, Tomas M, Medrano H, Flexas J. 2007. Aquaporin expression in response to different water stress intensities and recovery in Richter-110 (Vitis sp.): relationship with ecophysiological status. Planta 226: 671-681.

Gerry AK, Wilson SD. 1995. The influence of initial size on the competitive responses of six plantspecies. Ecology 76: 272-279.

Gersani M, Brown JS, O'Brien EE, Maina GM, Abramsky Z. 2001. Tragedy of the commons as a result of root competition. Journal of Ecology 89: 660-669.

Geßler A, Kreuzwieser J, Dopatka T, Rennenberg H. 2002. Diurnal courses of ammonium net uptake by the roots of adult beech (Fagus sylvatica) and spruce (Picea abies) trees. Plant and Soil 240: 23-32.

Gieger T. 2002. Auswirkungen von Trockenheit und Entlaubung auf den Wasserhaushalt von Stiel- und Traubeneiche. PhD thesis. University of Göttingen, Germany.

Gieger T, Thomas FM. 2002. Effects of defoliation and drought stress on biomass partitioning and water relations of Quercus robur and Quercus petraea. Basic and Applied Ecology 3: 171-181.

Goldberg DE. 1987. Neighborhood competition in an old-field plant community. Ecology 68: 1211-1223.

Goldberg DE, Landa K. 1991. Competitive effect and response - Hierarchies and correlated traits in the early stages of competition. Journal of Ecology 79: 1013-1030.

Gower ST, Vogt KA, Grier CC. 1992. Carbon dynamics of Rocky-Mountain Douglas fir - Influence of water and nutrient availability. Ecological Monographs 62: 43-65.

Grams TEE, Kozovits AR, Reiter IM, Winkler JB, Sommerkorn M, Blaschke H, Häberle KH, Matyssek R. 2002. Quantifying competitiveness in woody plants. Plant Biology 4: 153-158.

Grime JP, Campbell BD, Mackey JML, Crick JC. 1991. Root plasticity, nitrogen capture and competitive ability. In: Atkinson D, ed. Plant root growth. An ecological perspective. London, UK: Blackwell, 381-397.

Hargrave KR, Kolb KJ, Ewers FW, Davis SD. 1994. Conduit diameter and drought-induced embolism in Salvia mellifera GREENE (Labiatae). New Phytologist 126: 695-705.

Harvey HP, van den Driessche R. 1997. Nutrition, xylem cavitation and drought resistance in hybrid poplar. Tree Physiology 17: 647-654.

Heilmeier H, Erhard M, Wartinger A, Brinckmann E, Horn R, Schulze ED. 2001. Biomass partitioning in response to soil drought: A pot experiment with Prunus dulcis trees during four years. Basic and Applied Ecology 2: 165-175.

Hertel D. 1999. The fine root system of mixed stands of European beech: structure, dynamics and interspecific competition (In German). Berlin, Germany: Cramer.

Hertel D, Leuschner C. 2006. The in situ root chamber: A novel tool for the experimental analysis of root competition in forest soils. Pedobiologia 50: 217-224. 
Hodge A, Robinson D, Griffiths BS, Fitter AH. 1999a. Nitrogen capture by plants grown in N-rich organic patches of contrasting size and strength. Journal of Experimental Botany 50: 1243-1252.

Hodge A, Robinson D, Griffiths BS, Fitter AH. 1999b. Why plants bother: root proliferation results in increased nitrogen capture from an organic patch when two grasses compete. Plant, Cell and Environment 22: 811-820.

Hodge A. 2003. Plant nitrogen capture from organic matter as affected by spatial dispersion, interspecific competition and mycorrhizal colonization. New Phytologist 157: 303-314.

Hofman TB, Ennik GC. 1980. Investigation into plant characters affecting the competitive ability of perennial Ryegrass (Lolium perenne L.). Netherlands Journal of Agricultural Science 28: 97-109.

Hofman TB, Ennik GC. 1982. The effect of root mass of perennial ryegrass (Lolium perenne L.) on the competitive ability with respect to couchgrass (Elytrigia repens (L.) DESV.). Netherlands Journal of Agricultural Science 30: 275-283.

Hutchings MJ, John EA, Wijesinghe DK. 2003. Toward understanding the consequences of soil heterogeneity for plant populations and communities. Ecology 84: 2322-2334.

Irvine J, Perks MP, Magnani F, Grace J. 1998. The response of Pinus sylvestris to drought: stomatal control of transpiration and hydraulic conductance. Tree Physiology 18: 393-402.

Jackson RB, Caldwell MM. 1996. Integrating resource heterogeneity and plant plasticity: Modelling nitrate and phosphate uptake in a patchy soil environment. Journal of Ecology 84: 891-903.

Jarbeau JA, Ewers FW, Davis SD. 1995. The mechanism of water-stress induced embolism in two species of Chaparral shrubs. Plant, Cell and Environment 18: 189-196.

Johnson HA, Biondini ME. 2001. Root morphological plasticity and nitrogen uptake of 59 plant species from the Great Plains grasslands, USA. Basic and Applied Ecology 2: 127-143.

Joslin JD, Wolfe MH, Hanson PJ. 2000. Effects of altered water regimes on forest root systems. New Phytologist 147: 117-129.

Junghans U, Polle A, Duchting P, Weiler E, Kuhlman B, Gruber F, Teichmann T. 2006. Adaptation to high salinity in poplar involves changes in xylem anatomy and auxin physiology. Plant, Cell and Environment 29: 1519-1531.

Kalisz PJ, Zimmerman RW, Muller RN. 1987. Root density, abundance, and distribution in the mixed mesophytic forest of eastern Kentucky. Soil Science Society of America Journal 51: 220-225.

Karlsson PE, Medin EL, Wallin G, Selldén G, Skärby L. 1997. Effects of ozone and drought stress on the physiology and growth of two clones of Norway spruce (Picea abies). New Phytologist 136: 265-275.

Kavanagh KL, Zaerr JB. 1997. Xylem cavitation and loss of hydraulic conductance in Western hemlock following planting. Tree Physiology 17: 59-63.

Kelly JM, Chappelka AH, Lockaby BG. 1994. Measured and estimated parameters for a model of nutrient uptake by trees. New Zealand Journal of Forestry Science 24: 213-225.

Kelly JM, Graves WR, Aiello A. 2000. Nitrate uptake kinetics for rooted cuttings of Acer rubrum L.. Plant and Soil 221: 221-230.

Kelly JM, Scarbrough JD, Mays PA. 2001. Hardwood seedling root and nutrient parameters for a model of nutrient uptake. Journal of Environmental Quality 30: 427-439.

Kembel SW, Cahill JF. 2005. Plant phenotypic plasticity belowground: A phylogenetic perspective on root foraging trade-offs. The American Naturalist 166: 216-230.

Kolb KJ, Davis SD. 1994. Drought tolerance and xylem embolism in co-occurring species of Coastal sage and Chaparral. Ecology 75: 648-659.

Konôpka B, Noguchi K, Sakata T, Takahashi M, Konôpková Z. 2007. Effects of simulated drought stress on the fine roots of Japanese cedar (Cryptomeria japonica) in a plantation forest on the Kanto Plain, eastern Japan. Journal of Forest Research 12: 143-151.

Ladjal M, Huc R, Ducrey M. 2005. Drought effects on hydraulic conductivity and xylem vulnerability to embolism in diverse species and provenances of Mediterranean cedars. Tree Physiology 25: 1109-1117. 
Langan SJ, Ewers FW, Davis SD. 1997. Xylem dysfunction caused by water stress and freezing in two species of co-occurring chaparral shrubs. Plant, Cell and Environment 20: 425-437.

Leuschner C, Hertel D, Coners H, Büttner V. 2001. Root competition between beech and oak: a hypothesis. Oecologia 126: 276-284.

Leuschner C, Hertel D. 2003. Fine root biomass of temperate forests in relation to soil acidity and fertility, climate, age and species. In: Esser K, Lüttge U, Beyschlag W, Hellwig F, eds. Progress in Botany 64. Berlin, Germany: Springer, 405-438.

Leuschner C, Coners H, Icke R. 2004a. In situ measurement of water absorption by fine roots of three temperate trees: species differences and differential activity of superficial and deep roots. Tree Physio$\operatorname{logy} 24: 1359-1367$.

Leuschner C, Hertel D, Schmid I, Koch O, Muhs A, Hölscher D. 2004b. Stand fine root biomass and fine root morphology in old-growth beech forests as a function of precipitation and soil fertility. Plant and Soil 258: 43-56.

Livesley SJ, Gregory PJ, Buresh RJ. 2000. Competition in tree row agroforestry systems. 1. Distribution and dynamics of fine root length and biomass. Plant and Soil 227: 149-161.

Lo Gullo MA, Salleo S. 1991. Three different methods for measuring xylem cavitation and embolism - A comparison. Annals of Botany 67: 417-424.

Lo Gullo MA, Salleo S. 1992. Water storage in the wood and xylem cavitation in 1-year-old twigs of Populus deltoides BARTR.. Plant, Cell and Environment 15: 431-438.

Lo Gullo MA, Nardini A, Salleo S, Tyree MT. 1998. Changes in root hydraulic conductance $\left(\mathrm{K}_{\mathrm{R}}\right)$ of Olea oleaster seedlings following drought stress and irrigation. New Phytologist 140: 25-31.

Lovisolo C, Schubert A. 1998. Effects of water stress on vessel size and xylem hydraulic conductivity in Vitis vinifera L.. Journal of Experimental Botany 49: 693-700.

Löf M, Bolte A, Welander NT. 2005. Interacting effects of irradiance and water stress on dry weight and biomass partitioning in Fagus sylvatica seedlings. Scandinavian Journal of Forest Research 20: $322-328$.

Lucash MS, Eissenstat DM, Joslin JD, McFarlane KJ, Yanai RD. 2007. Estimating nutrient uptake by mature tree roots under field conditions: challenges and opportunities. Trees - Structure and Function 21: 593-603.

Machado JL, Tyree MT. 1994. Patterns of hydraulic architecture and water relations of two tropical canopy trees with contrasting leaf phenologies - Ochroma pyramidale and Pseudobombax septenatum. Tree Physiology 14: 219-240.

Maherali H, DeLucia EH. 2000. Xylem conductivity and vulnerability to cavitation of Ponderosa pine growing in contrasting climates. Tree Physiology 20: 859-867.

Maherali H, Williams BL, Paige KN, DeLucia EH. 2002. Hydraulic differentiation of Ponderosa pine populations along a climate gradient is not associated with ecotypic divergence. Functional Ecology 16: $510-521$

Maina GG, Brown JS, Gersani M. 2002. Intra-plant versus inter-plant root competition in beans: avoidance, resource matching or tragedy of the commons. Plant Ecology 160: 235-247.

Meier IC, Leuschner C. 2008a. Genotypic variation and phenotypic plasticity in the drought response of fine roots of European beech. Tree Physiology 28: 297-309.

Meier IC, Leuschner C. 2008b. The belowground drought response of European beech: fine root biomass and carbon partitioning in 14 mature stands across a precipitation gradient. Global Change Biology, in press.

Mencuccini M, Bonosi L. 2001. Leaf/sapwood area ratios in Scots pine show acclimation across Europe. Canadian Journal of Forest Research 31: 442-456.

Miller TE, Werner PA. 1987. Competitive effects and responses between plant species in a first-year oldfield community. Ecology 68: 1201-1210.

Mou P, Jones RH, Mitchell RJ, Zutter B. 1995. Spatial-distribution of roots in sweetgum and Loblolly pine monocultures and relations with aboveground biomass and soil nutrients. Functional Ecology 9: 689-699. 
Nardini A, Pitt F. 1999. Drought resistance of Quercus pubescens as a function of root hydraulic conductance, xylem embolism and hydraulic architecture. New Phytologist 143: 485-493.

Navarro A, Bañon S, Olmos E, Sanchez-Blanco MJ. 2007. Effects of sodium chloride on water potential components, hydraulic conductivity, gas exchange and leaf ultrastructure of Arbutus unedo plants. Plant Science 172: 473-480.

Newbery DM, Newman EI. 1978. Competition between grassland plants of different initial sizes. Oecologia 33: 361-380.

Nord-Larsen T, Damaard C, Weiner J. 2006. Quantifying size-asymmetric growth among individual beech trees. Canadian Journal of Forest Research 36: 418-425.

O'Brien EE, Brown JS, Moll JD. 2007. Roots in space: a spatially explicit model for below-ground competition in plants. Proceedings of the Royal Society B: Biological Sciences 274: 929-934.

Osunubi O, Davies WJ. 1981. Root growth and water relations of oak and birch seedlings. Oecologia 51:343-350.

Pallardy SG, Rhoads JL. 1993. Morphological adaptations to drought in seedlings of deciduous angiosperms. Canadian Journal of Forest Research 23: 1766-1774.

Parker MM, Van Lear DH. 1996. Soil heterogeneity and root distribution of mature Loblolly pine stands in Piedmont soils. Soil Science Society of America Journal. 60: 1920-1925.

Perks MP, Irvine J, Grace J. 2004. Xylem acoustic signals from mature Pinus sylvestris during an extended drought. Annals of Forest Science 61: 1-8.

Pietikäinen J, Vaijärvi E, Ilvesniemi H, Fritze H, Westman CJ. 1999. Carbon storage of microbes and roots and the flux of $\mathrm{CO}_{2}$ across a moisture gradient. Canadian Journal of Forest Research 29: 1197-1203.

Pire R, Sanabria ME, Pereira A, Diez J. 2007. Hydraulic conductivity and xylem vessels thickness in five grapevine materials under water deficits. Interciencia 32: 35-40.

Plamboeck AH, Grip H, Nygren U. 1999. A hydrological tracer study of water uptake depth in a Scots pine forest under two different water regimes. Oecologia 119: 452-460.

Prigge M. 2005. Physiologische und morphologische Anpassung von Buchen- und Traubeneichenfeinwurzeln an experimentell erhöhte Trockenheit. Diploma thesis. University of Göttingen, Germany.

Pronk AA, De Willigen P, Heuvelink E, Challa H. 2002. Development of fine and coarse roots of Thuja occidentalis 'Brabant' in non-irrigated and drip irrigated field plots. Plant and Soil 243: 161-171.

Rajaniemi TK. 2003. Evidence for size asymmetry of belowground competition. Basic and Applied Ecology 4: 239-247.

Rajaniemi TK, Reynolds HL. 2004. Root foraging for patchy resources in eight herbaceous plant species. Oecologia 141: 519-525.

Rajaniemi TK. 2007. Root foraging traits and competitive ability in heterogeneous soils. Oecologia 153: $145-152$.

Ramos C, Kaufmann MR. 1979. Hydraulic resistance of rough lemon roots. Physiologia Plantarum 45: $311-314$

Ranasinghe MS, Milburn JA. 1995. Xylem conduction and cavitation in Hevea brasiliensis. Journal of Experimental Botany 46: 1693-1700.

Raynaud X, Leadley PW. 2004. Soil characteristics play a key role in modelling nutrient competition in plant communities. Ecology 85: 2200-2214.

Raynaud X, Leadley PW. 2005. Symmetry of belowground competition in a spatially explicit model of nutrient competition. Ecological Modelling 189: 447-453.

Rice KJ, Matzner SL, Byer W, Brown JR. 2004. Patterns of tree dieback in Queensland, Australia: the importance of drought stress and the role of resistance to cavitation. Oecologia 139: 190-198.

Rieger M. 1995. Offsetting effects of reduced root hydraulic conductivity and osmotic adjustment following drought. Tree Physiology 15: 379-385.

Robinson D. 1994. The responses of plants to non-uniform supplies of nutrients. New Phytologist 127: 635-674. 
Robinson D, Hodge A, Griffiths BS, Fitter AH. 1999. Plant root proliferation in nitrogen-rich patches confers competitive advantage. Proceedings of the Royal Society of London Series B - Biological Sciences 266: 431-435.

Rose L. 2007. Trockenstressempfindlichkeit und Palatibilität der Blätter von Jungbuchen zentraler und marginaler Arealherkünfte. Diploma thesis. University of Göttingen, Germany.

Santantonio D, Hermann RK. 1985. Standing crop, production, and turnover of fine roots on dry, moderate, and wet sites of mature Douglas fir in western Oregon. Annals of Forest Science 42: 113-142.

Schenk HJ. 2006. Root competition: beyond resource depletion. Journal of Ecology 94: 725-739.

Schmitz N, Verheyden A, Beeckman H, Kairo JG, Koedam N. 2006. Influence of a salinity gradient on the vessel characters of the mangrove species Rhizophora mucronata. Annals of Botany 98: 1321-1330.

Schumann J. 2006. Der Permanente Welkepunkt - Ein Vergleich zwischen Buche, Eiche, Esche und Waldziest. Diploma thesis. University of Göttingen, Germany.

Schwinning S. 1996. Decomposition analysis of competitive symmetry and size structure dynamics. Annals of Botany 77: 47-57.

Schwinning S, Weiner J. 1998. Mechanisms determining the degree of size asymmetry in competition among plants. Oecologia 113: 447-455.

Searson MJ, Thomas DS, Montagu KD, Conroy JP. 2004. Wood density and anatomy of water-limited eucalypts. Tree Physiology 24: 1295-1302.

Sellin A. 2001. Hydraulic and stomatal adjustment of Norway spruce trees to environmental stress. Tree Physiology 21: 879-888.

Shumway DL, Steiner KC, Abrams MD. 1991. Effects of drought stress on hydraulic architecture of seedlings from five populations of Green ash. Canadian Journal of Botany 69: 2158-2164.

Shumway DL, Steiner KC, Kolb TE. 1993. Variation in seedling hydraulic architecture as a function of species and environment. Tree Physiology 12: 41-54.

Siemens JA, Zwiazek JJ. 2003. Effects of water deficit stress and recovery on the root water relations of trembling aspen (Populus tremuloides) seedlings. Plant Science 165: 113-120.

Siemens JA, Zwiazek JJ. 2004. Changes in root water flow properties of solution culture-grown trembling aspen (Populus tremuloides) seedlings under different intensities of water-deficit stress. Physiologia Plantarum 121: 44-49.

Simonin G, Cochard H, Delatour C, Granier A, Dreyer E. 1994. Vulnerability of young oak seedlings (Quercus robur L.) to embolism - Responses to drought and to an inoculation with Ophiostoma querci (GEORGEVITCH) NANNF.. Annals of Forest Science 51: 493-504.

Sobrado MA. 2001. Hydraulic properties of a mangrove Avicennia germinans as affected by NaCl. Biologia Plantarum 44: 435-438.

Sobrado MA. 2007. Relationship of water transport to anatomical features in the mangrove Laguncularia racemosa grown under contrasting salinities. New Phytologist 173: 584-591.

Sparks JP, Black RA. 1999. Regulation of water loss in populations of Populus trichocarpa: the role of stomatal control in preventing xylem cavitation. Tree Physiology 19: 453-459.

Sperry JS, Donnelly JR, Tyree MT. 1988. A method for measuring hydraulic conductivity and embolism in xylem. Plant, Cell and Environment 11: 35-40.

Sperry JS, Pockman WT. 1993. Limitation of transpiration by hydraulic conductance and xylem cavitation in Betula occidentalis. Plant, Cell and Environment 16: 279-287.

Sperry JS, Nichols KL, Sullivan JEM, Eastlack SE. 1994. Xylem embolism in ring-porous, diffuseporous, and coniferous trees of northern Utah and Interior Alaska. Ecology 75: 1736-1752.

Sperry JS, Saliendra NZ. 1994. Intra- and inter-plant variation in xylem cavitation in Betula occidentalis. Plant, Cell and Environment 17: 1233-1241.

Sperry JS, Ikeda T. 1997. Xylem cavitation in roots and stems of Douglas fir and White fir. Tree Physiology 17: 275-280. 
Sword Sayer MA, Brissette JC, Barnett JP. 2005. Root growth and hydraulic conductivity of Southern pine seedlings in response to soil temperature and water availability after planting. New Forests 30: $253-272$

Thomas FM. 2000. Growth and water relations of four deciduous tree species (Fagus sylvatica L., Quercus petraea [MATt.] Liebl., Q. pubescens Willd., Sorbus aria [L.] CR.) occurring at CentralEuropean tree-line sites on shallow calcareous soils: physiological reactions of seedlings to severe drought. Flora 195: 104-115.

Thomas FM, Gausling T. 2000. Morphological and physiological responses of oak seedlings (Quercus petraea and Quercus robur) to moderate drought. Annals of Forest Science 57: 325-333.

Thomas SC, Weiner J. 1989. Including competitive asymmetry in measures of local interference in plant populations. Oecologia 80: 349-355.

Tilman D. 1988. Plant strategies and the dynamics of plant communities. Princeton, USA: Princeton University Press.

Tognetti R, Johnson JD, Michelozzi M . 1995. The response of European beech (Fagus sylvatica L.) seedlings from two Italian populations to drought and recovery. Trees - Structure and Function 9: 348-354.

Tognetti R, Michelozzi M, Giovannelli A. 1997. Geographical variation in water relations, hydraulic architecture and terpene composition of Aleppo pine seedlings from Italian provenances. Tree Physiology 17: 241-250.

Tognetti R, Longobucco A, Raschi A. 1998. Vulnerability of xylem to embolism in relation to plant hydraulic resistance in Quercus pubescens and Quercus ilex co-occurring in a Mediterranean coppice stand in central Italy. New Phytologist 139: 437-447.

Tomlinson PT, Anderson PD. 1998. Ontogeny affects response of northern red oak seedlings to elevated $\mathrm{CO}_{2}$ and water stress - II. Recent photosynthate distribution and growth. New Phytologist 140: 493-504.

Torreano SJ, Morris LA. 1998. Loblolly pine root growth and distribution under water stress. Soil Science Society of America Journal 62: 818-827.

Tyree MT, Alexander J, Machado JL. 1992. Loss of hydraulic conductivity due to water-stress in intact juveniles of Quercus rubra and Populus deltoides. Tree Physiology 10: 411-415.

Tyree MT, Cochard H, Cruiziat P, Sinclair B, Améglio T. 1993. Drought-induced leaf shedding in walnut - Evidence for vulnerability segmentation. Plant, Cell and Environment 16: 879-882.

Tyree MT, Kolb KJ, Rood SB, Patiño S. 1994. Vulnerability to drought-induced cavitation of Riparian cottonwoods in Alberta - A possible factor in the decline of the ecosystem. Tree Physiology 14: 455-466.

Van Hees AFM. 1997. Growth and morphology of Pedunculate oak (Quercus robur L.) and beech (Fagus sylvatica L.) seedlings in relation to shading and drought. Annals of Forest Science 54: 9-18.

Vilagrosa A, Bellot J, Vallejo VR, Gil-Pelegrín E. 2003. Cavitation, stomatal conductance, and leaf dieback in seedlings of two co-occurring Mediterranean shrubs during an intense drought. Journal of Experimental Botany 54: 2015-2024.

Villagra PE, Cavagnaro JB. 2005. Effects of salinity on the establishment and early growth of Prosopis argentina and Prosopis alpataco seedlings in two contrasting soils: Implications for their ecological success. Austral Ecology 30: 325-335.

Villagra PE, Cavagnaro JB. 2006. Water stress effects on the seedling growth of Prosopis argentine and Prosopis alpataco. Journal of Arid Environments 64: 390-400.

Volder A, Smart DR, Bloom AJ, Eissenstat DM. 2005. Rapid decline in nitrate uptake and respiration with age in fine lateral roots of grape: implications for root efficiency and competitive effectiveness. New Phytologist 165: 493-502.

Volkmer C, Rennenberg H. 1999. Untersuchungen zur Streß-Sensitivität von Ökotypen der Buche (Fagus sylvatica L.) III. Ergebnisse des Dachexperimentes Conventwald. Karlsruhe, Germany, Forschungszentrum Karlsruhe.

von Wettberg EJ, Weiner J. 2003. Larger Triticum aestivum plants do not preempt nutrient-rich patches in a glasshouse experiment. Plant Ecology 169: 85-92. 
Weiner J. 1986. How competition for light and nutrients affects size variability in Ipomoea tricolor populations. Ecology 67: 1425-1427.

Weiner J, Thomas SC. 1986. Size variability and competition in plant monocultures. Oikos 47: 211-222.

Weiner J, Berntson GM, Thomas SC. 1990. Competition and growth form in a woodland annual. Journal of Ecology 78: 459-469.

Weiner J, Wright DB, Castro S. 1997. Symmetry of below-ground competition between Kochia scoparia individuals. Oikos 79: 85-91.

Weissbein S. 2006. Characterization of new olive (Olea europea L.) varieties response to irrigation with saline water in the Ramat Negev area. Master thesis. Ben-Gurion University of the Negev, Israel.

Wijesinghe DK, John EA, Beurskens S, Hutchings MJ. 2001. Root system size and precision in nutrient foraging: responses to spatial pattern of nutrient supply in six herbaceous species. Journal of Ecology 89: 972-983.

Wilson JB. 1988. The effect of initial advantage on the course of plant competition. Oikos 51: 19-24.

Zamora D, Jose S, Nair P. 2007. Morphological plasticity of cotton roots in response to interspecific competition with pecan in an alleycropping system in the southern United States. Agroforestry Systems 69: 107-116.

Zekri M, Parsons LR. 1989. Growth and root hydraulic conductivity of several citrus rootstocks under salt and polyethylene glycol stresses. Physiologia Plantarum 77: 99-106.

Zwieniecki MA, Hutyra L, Thompson MV, Holbrook NM. 2000. Dynamic changes in petiole specific conductivity in Red maple (Acer rubrum L.), Tulip tree (Liriodendron tulipifera L.) and northern Fox grape (Vitis labrusca L.). Plant, Cell and Environment 23: 407-414. 


\section{ACKNOWLEDGEMENTS}

First of all, I would like to thank Prof. Dr. Christoph Leuschner for the opportunity to run and finish this $\mathrm{PhD}$ thesis in such a self-determined manner.

A grant by the "Stiftung der deutschen Wirtschaft - Studienförderwerk Klaus Murmann" enabled me to start this research but further allow me to 'see beyond the end of my nose' in several workshops and discussions. The Dryland Research Specific Support Action (DR-SSA) of the European Union (FP6) thankfully supported the 'olive project'. Needless to say, this thesis project could not have been undertaken without the support of others, especially the members of the Department of Plant Ecology and the Experimental Botanical Garden staff - It was often hard work, especially in the field, but is was quite more often fun! I am especially indebted to Jutta Cernitzki, Dr. Heinz Coners, Dirk Deilke, Heiko Eichner, Marianne Gscheidlen, Regina Helbig, Dr. Dietrich Hertel, Ute Schlonsog, Mechthild Stange, Ulrich Werder, and last but not least my former diploma students Marcel Prigge and Jasmin Schumann. Dr. Jhonathan E. Ephrath made my stay in Sede Boqer successful and enjoyable. Thanks to all of you!

Several people have played a decisive role in saving me from going 'bananas' and leaving all these tiny little fine roots behind. These persons are...

my flat mates: Farina Herrmann, Dr. Volker Hesse, Ralph Jacob, Katha Kulig, Katrin Orth, Dr. Barbara Schauenburg, Matthias Samwer, Marcus Schnuck, and my friends: Grischa Bertram, Dr. Stefan Böttner, Dr. Sabine Budde, Dr. Christian Elend, Jörn Fischer, Mario Fleckenstein, Lena Gandlina, Dr. Dirk Gaul, Steffi Goldacker, Isabella Herrmann, Frank Käding, Ute Luginbühl, Martin Marställer, Hilmar Müller, Doro Schöling, Janka Timm, Muharrem Yildirim, Anja \& Dr. Andreas Zembrzycki, and especially Laura Rose and Henrike Wagner.

Without your companionship and support, this $\mathrm{PhD}$ thesis would not have been written!

Finally, special thanks to my family, Renate, Helmut and Oliver Rewald, and Elias Müller, for your everlasting interest, support, and love. 


\section{CURRICULUM VitAE}

Personal details

Date of birth $\quad$ 15. June 1978

Place of birth Kassel, Germany

Nationality German

Education

2004-2008 PhD study at the Department of Plant Ecology,

Albrecht-von-Haller Institute of Plant Sciences,

Georg-August University of Göttingen, Germany.

$2000-2003$

Study of biology at the Georg-August University of Göttingen, Germany; Degree obtained: Diplom Biologe.

$1998-2000$

Study of biology, geography, and environmental law (certificate) at the University of Kassel, Germany.

1990-1997

Freiherr-vom-Stein Gesamtschule Hess. Lichtenau, Germany;

High School graduation: Abitur. 